



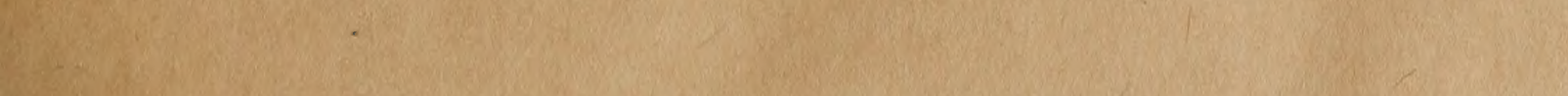





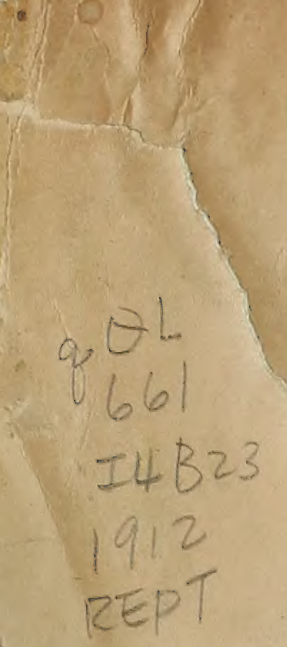

Iinemoirs of the Iisuseum of Comparative Zoölogy AT. HARVARD COLLEGE.

Vol. XLIV. No. 1.

\section{A CONTRIBUTION TO THE ZOÖGEOGRAPHY OF THE EAST INDIAN ISLANDS.}

By THOMAS BARBOUR.

WITH EIGHT PLATES.

CAMBRIDGE, U.S. A.:

printed for the museum.

November, 1912. 



\section{TABLE OF CONTENTS.}

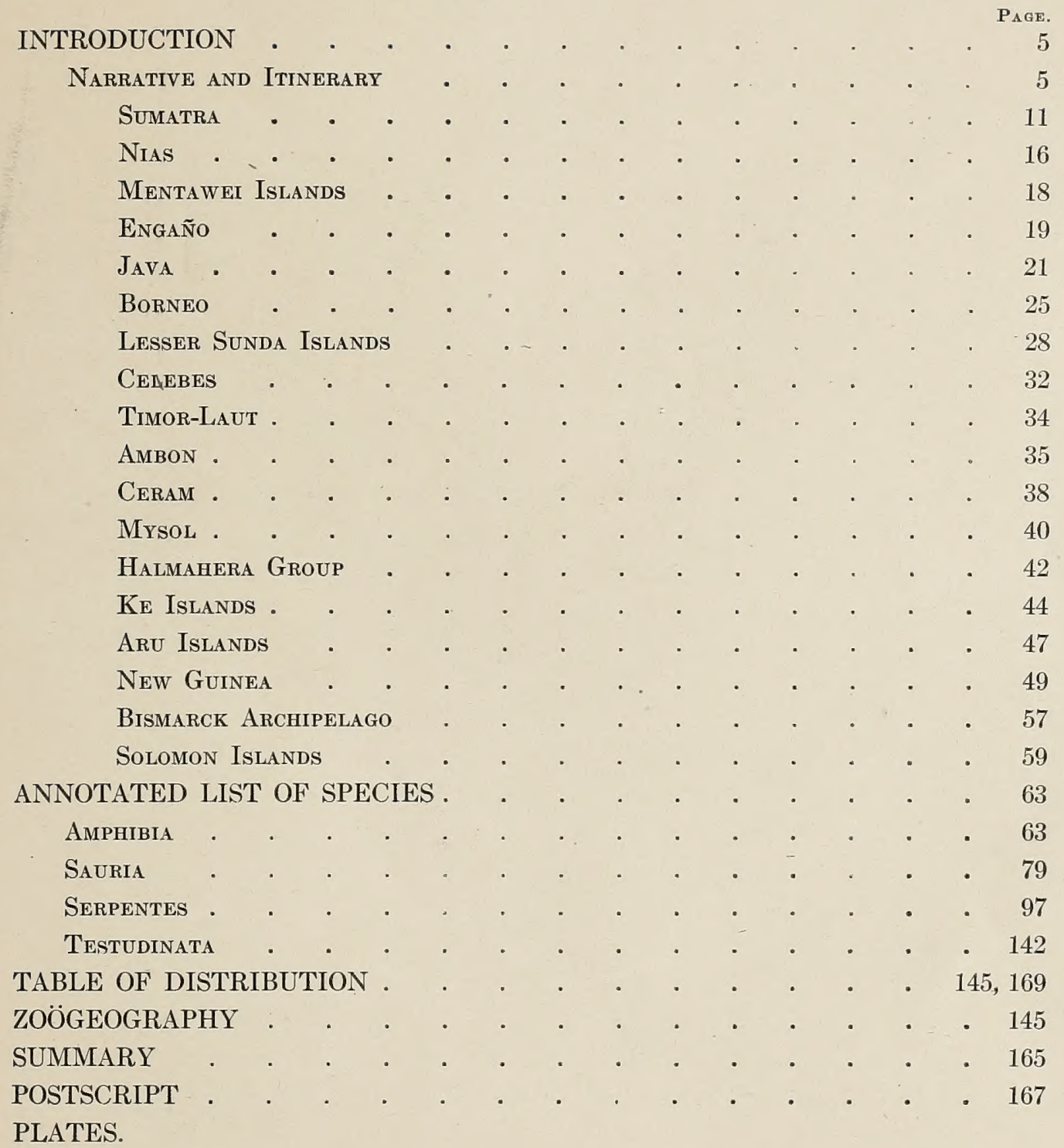





\section{A CONTRIBUTION TO THE ZOÖGEOGRAPHY OF THE EAST INDIAN ISLANDS.}

\section{INTRODUCTION.}

During 1906-1907 I visited the East Indies. A short preliminary account of the trip, with notices of some new species, was published in the Bulletin of this Museum (Bull. M. C. Z., 1908, 51, p. 313-325). The descriptions of other new species based wholly or in part on the material collected have appeared in the Proceedings of the Biological society of Washington, 1908, 21, p. 39-42, 189-190; 1910, 23, p. 89-90, p. 169-170; 1911, 24, p. 15-22. The present paper deals more fully with the collections of reptiles and amphibians.

\section{NARRATIVE AND ITINERARY.}

It is hardly necessary to give more than a brief outline of the early part of the voyage. Bombay was reached November 2, 1906, via Peninsula and Oriental S. S. Co. ships from Brindisi, via Port Said and Aden. A short time was spent in crossing India, visiting the hills about Darjeeling, the Teesta Valley, and the Sunderbans of Lower Bengal. Rangoon was reached by the ship Bharata belonging to the British India Steam Navigation Company. Visits to Mandalay and Bhamo, at the head of navigation on the Irewady River, with short collecting trips to one or two other localities, completed the work done in Burma. Another ship of the same line was taken to Singapore via Penang.

In Singapore I was fortunate enough to find a Chinese boy, Ah Woo by name, who became a most faithful servant and a very skilful collector. His slight knowledge of English, added to a fluency in Malay, made him often helpful as an interpreter, and even at times as a teacher. The Malay language as spoken in the bazaars is not difficult, and a knowledge of sentence formation once gained, proficiency in the language involves only the memorizing of a vocabulary.

W ork in the East Indies began with collecting for a few days about Batavia,

${ }^{1}$ Contributions from the Zoölogical Laboratory of the Museum of Comparative Zoölogy at Harvard College, under the direction of E. L. Mark.- No. 231. 
whence we proceeded to Buitenzorg. Here I had the assistance of many influential persons, by whose aid several excellent Javanese helpers were got. These men were especially useful from the fact that either they had been on the Siboga expedition, or had otherwise acquired useful training. After arranging for the collecting and preserving of Javan material, we proceeded by rail to Sourabaya, and boarded there the S. S. Both of the Koninklijke Paketvaart Maatschappij. This small steamer was accustomed to make three trips a year through the islands to New Guinea. It is impossible to express adequately my feelings of obligation for the kindness of the officials of the line and the officers of the ship in forwarding our aims. To accommodate our needs the ship was delayed and her regular itinerary changed, but with no word of complaint from any source. The kindness of the chief agent of the Company in Batavia in regard to the whole expense of the trip showed how widespread is the desire to forward the scientific examination of the fauna of these colonies.

In some ports arrangements were made to leave a collector who was to be picked up again on the return trip. In other cases it was possible to arrange with the people to have them assemble material for purchase on our return. In many cases the fact that the ship made calls at a number of near by ports on the same island made it possible to see a large part of some of these various localities. Most of the steaming was done at night, and there were but few days on the voyage, which lasted more than two months, when it was impossible for all hands to be at work ashore, generally with a very large and useful following of local natives. This method of collecting would of course avail little in an intensive study of the fauna of an island as regards a single group of animals, but for the taking of reptiles and amphibians it works very well. Ten people working together will, I think, take more in one day than a single person will take in the same locality in ten days. On the island of Halmahera ten persons worked at six localities for eleven days. On New Guinea stays of one to three days were made at nine localities, as well as a couple of days each at Saonek on the neighboring island of Waigiu, and at the island of Mapia between New Guinea and the Carolines. Thus it was possible to do far more shore collecting than would be possible for a naturalist attached to one of the regular vessels employed in deep sea or other scientific research. Both Malays and Papuans can be taught to collect, and do so eagerly; the pay in the case of the Papuans being tobacco, brass wire cut into short lengths, and red cloth. A popular account of the natives, etc., of the part of New Guinea visited has been published in the National geographic magazine for July and August, 1908. 
A list of the localities visited follows:-

Buleleng, Bali Island.

Ampenan, Lombok Island.

Makassar, Celebes Island.

Tifu, Buru Island.

Lawui, Obi Island.

Ambon or Amboina Island (town has same name).

Piru and Wahaai, Ceram Island.

Gane, Galela, Tobello, Ake-Selaka, Patani, and Weeda, on Halmahera Island.

Ternate, on island of same name.

Saonek, Waigiu Island.

Manokwari and Humboldt's Bay, mainland of Papua.

Sorong, on a small island barely separated by a narrow strait from Papua. The same may be said of the islands Roon and Djamna. The other Papuan localities were Pom, Wooi, and Ansus, on Jobi; and Meosbundi, on Wiak; both islands lying in Geelvink Bay, New Guinea.

At the time this visit was made to Papua, conditions were quite different from what they are even now. There were in all the vast region only three posts, each with an Assistant Resident:-Merauke, in southwest New Guinea; Fak Fak, in western New Guinea; and Manokwari, near Doreh on Geelvink Bay. The three mission stations were in this latter region. At Sorong there was a Posthouder, but I have heard that he has been withdrawn. Since this voyage, however, a number of Dutch scientific parties have visited the country; and with the recent increase in the number of voyages of the trading steamer each year, the real primitive Papuan will in time disappear. British Papua, for a long while ably administered, has now a considerable white population of miners, planters, and traders. German New Guinea, or Kaiser Wilhelm's Land, has, if nothing else, a full corps of officials of every sort. This latter region, however, has proved a great disappointment as a colony, from every point of view. Dutch New Guinea, lying nearer the equator than the rest of the island, has a climate rather more unhealthy. It certainly has a vast area of low-lying swampy land. As the white population grows, however, modern knowledge as to the efficacy of drainage in combating malaria will undoubtedly make possible fairly healthy towns along the coast. The English have shown what can be 
done at Samarai in southeast Papua, once a deadly locality, now a comparatively liveable town.

So far the commerce with the Dutch section has been only trading with the natives, or a few resident Chinamen for Bird-of-Paradise skins, dammar gum, and forest products, such as wild nutmegs, etc. The bird skins at the rate they are being taken will in time become rare in the accessible regions. The fact that adult males alone are wanted - the inconspicuous females going unharmed and often unknown to the native hunters - accounts for the fact that the bird is still abundant. Its raucous screams may probably still be heard from the porch of the Residency at Manokwari. The Great Bird-of-Paradise (Paradisea apoda Linné), found only in the Aru Islands, is already much diminished in number; and even the nearly related species, (Paradisea jobiensis Rothschild), which is confined to Jobi Island, is also rare, owing to the fact that its plumes are longer and more silky than those of its more common congener, (Paradisea minor Shaw) on the mainland of Papua. The many other species of the Paradiseidae, especially those confined to the inland mountains, are only hunted in a desultory way, and have suffered no diminution of numbers. It is to be hoped that there may be some regulation of this traffic, perhaps a conservative limit set, and only a certain number of skins allowed to be bartered from each village. This would work no injustice to the native, as he buys with his skins only what to him are luxuries. It is probable that such measures would meet with great opposition among the Dutch merchants at Ternate and Makassar. Until some other reason arises for sending a ship to Papua - as, for instance, the starting of rubber plantations - these voyages can only be made to pay by the trade in skins; but this alone now makes the voyage one of the most profitable of any in the Indies.

After the return to Java from the voyage, some time was spent at Buitenzorg in packing the collections, and also in making several short collecting trips to various parts of the island. In this way Sindanglaia, Tjibodas, and other near by villages were visited. At the last-named locality is situated the mountain branch of the Buitenzorg Botanical Gardens. Then Bandoung, Garut, and Djokjakarta were visited, and short trips made in several directions from each town. On the previous trip through the island en route to Sourabaya, before sailing to Bali from that port, some collecting was done in east Java. From Buitenzorg our collectors were sent for periods of several weeks each to Sukabumi, Tjibodas, and to localities on the slopes of the volcano Salak. By keeping separate these various collections made at different altitudes, we are 
able to throw a little light on the vertical distribution of some of the most prominent components of the fauna, especially the reptiles and amphibians.

A word regarding the collections in some other branches of zoölogy. The series of mammals was small, but contained a single specimen of high interest, the type of a new genus of marsupials of the Peramelidae. It has been called Suillomeles hispida Allen \& Barbour (Proc. N. E. zoöl. club, 1909, 4, p. 43-46, pl. 2-3). A number of other forms were new to the collections of the Museum. Two specimens of Proechidna were added to material already in the Museum, and others have been obtained since. As the Museum now contains skins, specimens in spirits, and complete skeletons, it has an almost unrivalled collection of this interesting form, the anatomy of which is reported by Dr. G. M. Allen (Memoirs M. C. Z., October, 1912, 40, p. 249-307, 2 plates).

Nothing of special interest is to be said regarding the small collection of birds. Series of specimens of Paradisea jobiensis, and of Semioptera halmaherae were among the more interesting, in that they were previously unrepresented in the Museum's collections.

The fishes are as yet unstudied. The collection, however, contains a few cyprinoids from Lombok. Max Weber (Zool. ergeb., 1894, 3, p. 461) has shown that this is one of the families of fresh-water fishes characteristic of continental Asia which are also known to exist throughout the islands as far as Bali. The discovery that a species of this family occurs in Lombok also, is of interest in connection with the question as to the importance of the Lombok-Bali boundary established by Wallace.

An account of the collection of Echinodermata has been written by Dr. Hubert Lyman Clark (Bull. M. C. Z., 1908, 51, p. 279-311). Miss Mary J. Rathbun has also reported on the decapod Crustacea (Bull. M. C. Z., 1910, 52, p. 305-317, pl. 1-6).

The insects are as yet incompletely sorted; the ethnologic objects are on exhibition in the Peabody Museum of American Archaeology and Ethnology in Cambridge.

In conclusion, my deepest thanks are due, first of all, to Messrs. Alan W. Pim and Frank B. Sherring, of the Indian Civil Service, who aided most kindly and efficiently in making collections over a large part of the trip; to H. E. Lieut. Gen. van Heutz, late Governor-General of Dutch India; to the late Professor M. Treub, Director of Agriculture; to Major P. A. Ouwens, of the Zoölogical museum at Buitenzorg; to Dr. J. C. Koningsberger; and to Dr. P. N. van Kampen, also of the Department of Agriculture. All these gentlemen laid me 
under the deepest obligation for a multitude of favors. Nor can I forget many other friends:- Mr. G. A. Sedee of Ternate, and Mr. Duivenboden, of AkeSelaka, Halmahera, whose grandfather's schooner carried Wallace, the first naturalist to live in New Guinea. Then to many officials of the Koninklijke Paketvaart Maatschappij, whose constant help was invaluable, I here express my appreciation.

In preparing his report, I have been much aided by Dr. Leonhard Stejneger, Dr. G. A. Boulenger, Mr. Samuel Garman, and especially by Prof. E. L. Mark; though it is only fair to say that they should in no wise be held responsible for any opinions which are expressed herein. It is a pleasure to thank them for patient assistance.

Since writing the previous pages I have received for study a very extensive addition to my Javan material. My friend, Mr. Owen Bryant, in company with Mr. William Palmer, of the United States National Museum, spent somewhat more than a year in western Java, accumulating a large quantity of reptiles and amphibians. These I have been privileged to study, and to retain a series of desired species where duplicates exist, thanks to the kindness of the collector and to the authorities of the United States National Museum. Mr. Bryant's material has made it possible to examine very large numbers of individuals from the same localities, since he spent much time in several of the same places where I collected. I do not believe that it has ever been possible previously to examine so large an amount of Javanese material from a limited region, and with such full data. It is, however, unfortunate that the late receipt of the collection has not made it possible for me to examine it quite as critically as I should have wished to. Nevertheless, I have the data taken from the scale-counts of each snake; and these, with the notes I already had, make it possible to point out, probably with considerable certainty, the exact local average shown by many of the species, and in many cases to indicate the strong probability, or even certainty, of the occurrence in Java of geographic races of some of the continental species.

It is a pleasure to thank Mr. Bryant for making this collection, and also Mr. Ward Shepard for assistance in making notes for me concerning it; and especially, besides, to acknowledge the painstaking care which Mr. E. N. Fischer has expended upon the plates.

Fortunately it has been possible to obtain from the collections of Mr. A. E. Pratt and others some small series of examples which have been of the highest interest. These are in most cases mentioned passim. 
The collections of the Museum have, of course, been consulted freely, and references have been made to a few of the individuals contained in them. It is unfortunate that time does not permit the inclusion of notes on all the East Indian specimens available for study here. Many of these were brought back by the earlier American voyagers, and were sent by Louis Agassiz to Jan in Milan for identification; others, still, came here in early exchanges from the Paris museum, and were marked as types by A. Aug. Dumeril. While not holotypes in the sense in which the word type is commonly used now, they are undoubtedly a part of the typical series of many of the species described by Dumeril and Bibron in their Erpetologie géneral.

\section{Sumatra.}

The first island to be discussed, with direct regard to the relationships of its reptiles and amphibians, is Sumatra. A few words regarding its physical peculiarities are worth while. The island lies nearer to the Malay Peninsula than any other of the East Indies, the straits of Malacca in many places being less than fifty miles wide. There is a tradition that the lands joined almost within historic times. It is nearly one thousand miles long; and varies in width from between less than one hundred miles in the mountainous district of Atjeh in the north, to about two hundred miles at the region opposite the lower end of the Malay Peninsula. The main trend is from northwest to southeast, and throughout its entire length extends a backbone mountain range, which runs close to the western or Indian Ocean side of the island. This range, it is interesting to notice, is almost exactly parallel to the mountainous backbone of the Malay Peninsula, and to the series of mountainous islands which lie in the Indian Ocean off the coast of Sumatra in a long series, beginning with Simalur at the north and ending with Engaño towards the south. These may indicate corrugations along which foldings of great extent have occurred, but there is no direct evidence at hand on this point.

The configuration and form of the shore-line and bays of the islands off Sumatra, and of Sumatra itself, and more especially the suggestions which one gets from the soundings shown on the chart, lead one to suppose that this has been an area of general subsidence. It seems probable that the island of Simalur was connected with Sumatra by way of the Banjak Archipelago; that Nias was connected directly with Sumatra, quite independently of Simalur; and that the Mentawei Islands were connected together, and with Sumatra, through the 
Batu group; making it appear probable that in times past there were three great peninsulas jutting out in three directions from Sumatra, northeastward, eastward, and southeastward; and that, while the origins of these three peninsulas were very close together on the Sumatra shore, still they were not crossconnected with one another. This will be emphasized again when we consider the fauna of these various islands.

The same subsidence which broke up these peninsulas into islands probably separated Sumatra from the mainland.

Werner has suggested that these islands have each different Sumatran species upon them because they each lie opposite the particular ranges within Sumatra for various species; and that their species have thus come to them from just that part of Sumatra lying nearest them. This would suggest that Werner supposes the islands to have received their species by "flotsam and jetsam" methods, which I do not believe. The islands are very incompletely known, and this probably accounts for the discrepancies in the lists of species, which came by the land connections suggested above.

There is good reason to believe, owing to the fact that all the rivers of large size empty either into the straits of Malacca or into the southern part of the China Sea between Sumatra and Borneo, that the island at the present time lies nearer to the Peninsula, to the Riouw and Lingga Archipelagoes, and to the island of Banka, than it did in the recent past. All of this eastern coast region of Sumatra is composed of low, swampy alluvial lands, through which the rivers flow, carrying down the detritus from the mountains in the form of silt, which is constantly being deposited in the deltas of the rivers; and these deltas are also being extended fast by the great fringing zone of mangrove vegetation which lines the shore. The straits themselves are very shallow. This may be considered a recent re-approachment, which may serve to connect the lands again in a short period of time.

The reptiles and amphibians of the island show a very close relationship to those of the nearest mainland. Werner (Zool. jahrb. Syst., 1900, 13, p. 479-508, pl. 31-35) has arranged a complete list of the herpetologic fauna of the island, which, however, has been considerably changed by the researches of the last ten years. On pages 503-508 he presented some general conclusions regarding the geographical distribution of Sumatran reptiles and amphibians in comparison with those of Ceylon, Borneo, Java, and Celebes. The work itself is useful, but contains a considerable number of statements which may be justly challenged. In the first place, in 1896 Werner (Verh. Ges. Wien, 1896, 46, 
p. 13) reported Lygosoma chalcides (Linné) from Sumatra. He omitted this form, however, on page 15 of his 1900 list. Then again on p. 499, 500 of the latter list he records Gekko verticillatus [= gecko (Linné)] from Sumatra; while in the same paper, on page 505, he remarks "Eine sehr interessante Erscheinung ist die Vertretung gewisser Species Sumatras durch verwandte Species auf Java." He places Gekko stentor as Sumatran, and G. verticillatus as Javan, though both species occur on both islands. Calotes cristatellus is not in any way-characteristic of Sumatra, though it occurs in his list. C. jubatus, on the other hand, has been found in Java, but not yet in Sumatra. There are records for Enhydris plumbea and E. enhydris (which he calls Hypsirhina) in both Java and Sumatra. It is entirely possible that Werner has good reason to doubt the accuracy of some of the records which have been published in the past; though I have a letter from Dr. G. A. Boulenger, of the British museum, who tells me that he has recently received specimens of Calotes cristatellus from both Java and Sumatra, among other localities; and Flower, in his list of reptiles of the Malay Peninsula (Proc. Zool. soc. London, 1899, p. 603) records both G. stentor and G. verticillatus from Java, where I also collected both species. On page 504 Werner includes Typhlops braminus in his list of species which are known from Java and the Malay Peninsula, but not from Sumatra, even though he has reported it himself, from Sumatra only four pages earlier in the same paper. He remarks, besides, that Rana tigerina (spelled tigrina) is absent from Sumatra, though it is included by van Kampen in his excellent set of tables (Max Weber's Zool. ergeb., 1907, 4, 2). On page 504 we read, "Sumatra scheint....mit Borneo niemals in Zusammenhang gestanden, sondern seine Reptilien direct aus Malakka erhalten zu haben." While I am very much inclined to believe that this statement is correct, it is nevertheless somewhat difficult to reconcile with it the fact that we know a number of species from either Sumatra and Borneo, or Sumatra, Java, and Borneo, not including the Malay Peninsula.

We may proceed now to consider the composition of the fauna so far as our present knowledge permits. Throughout this paper species of both true sea-snakes and sea-turtles have been omitted. There are twelve species of freshwater turtles, none of them peculiar to the island, and all of them obviously of direct derivation from the Malay Peninsula. The same may be said of the three known species of crocodileans. It is interesting, however, to note that Tomistoma schlegeli was not known from Sumatra until 1890, while still more recently it has been added to the fauna of the Malay Peninsula. During the last fifteen years it has been discovered there in a number of different rivers. 
Annandale has remarked, however, that it is so rare that, according to the Malay crocodile hunters, there is about one of these to 100 of Crocodilus porosus. It is widespread through upper Sumatra.

The lizards are fifty in number, of which eleven - about twenty per cent, are peculiar to the island. Two genera, Phoxophrys and Lophocalotes, are autogenous.

As having a bearing on the question of the direct relationship of Sumatra with Borneo, the distributions of the following species are of interest:-

Spathoscalobotes mutilatus (Gthr.) occurs in Sumatra, Borneo, and Java.

Draco cornutus Gthr. comes from Sumatra, Borneo, and the Sulu Islands.

Gonyocephalus liogaster (Gthr.) has the same distribution.

Mabuya rudis Blgr. occurs in Sumatra, Borneo, and Celebes, as well as in the Mentawei group of islands.

It must be confessed that but little importance is to be given to two of these singular ranges on account of the fact that members of the Gekkonidae and Scincidae are, as is very well known, occasionally carried about accidentally.

There are one hundred and one species of snakes found on Sumatra, eleven of which are not found elsewhere; and it is interesting to note that while these form but about eleven per cent of the total number, or about half the percentage of the lizards that are autocthonous, the number contains four genera peculiar to the island. These are Anomolochilus, Iguanognathus, Anoplohydrus, and Xenochrophis. Two species, not remarkably different from each other, are interesting in that they represent a genus which has not been found in the Malay Peninsula, while it is known from west Africa and south China. The genus is represented in Sumatra by Opisthotrophis rugosa (van Lidth de Jeude); and in Borneo, by O. typica (Mocquard). The monotypic genus Elapoides is confined to Sumatra and Java. The species is E. fuscus Boie. Calamaria leucogaster Bleeker apparently occurs only in Sumatra and Borneo; while C. sumatrana Edeling, C. agamensis Bleeker, and C.melanota (Jan), as well as Boiga nigriceps (Gthr.), occur in Sumatra, Borneo, and Java.

Other species have distributions which are of interest:- Natrix conspicillata (Gthr.); Dryophis fasciolatus (Fischer), from Sumatra, Borneo, and the Natuna Islands; Lycodon albofuscus (Dum. \& Bibr.), from Sumatra, Nias, and Borneo; Psammodynastes pictus (Gthr.), from Sumatra, Riouw, and Borneo; and Trimeresurus puniceus (Boie) from Sumatra, Natuna, Borneo, and Java.

It must be admitted that, while Sumatra is the least explored of the Greater Sunda Islands, and while there undoubtedly remains a large number of species 
yet to be discovered in the highland areas, still the Ma!ay Peninsula has been very carefully studied during the last few years, and it is strange that there remains such a considerable number of species occurring in Sumatra and Borneo, which are not yet known in Malacca.

Since Werner's paper appeared, van Kampen has published his complete tables of distribution for the Amphibia throughout the Indian Archipelago, as well as two other papers of importance, all showing what remarkable forms have lain unknown for a long time on the islands. In 1905 van Kampen described Dyscophina volzi (Zool. jahrb. Syst., 1905, 22, p. 708-10, pl. 26). This is a representative of that small compact family, the Dyscophiidae, nearly all of which occur in Madagascar; the first known exception was the genus Calluella, which is Burmese. Van Kampen's form was described only a year after Boulenger made known Colpoglossus brooksi, a new genus and species of the same family from Borneo. These animals are difficult to find, owing to their burrowing habits. The way in which they have remained long undiscovered in a locality which has been well studied reminds one of the fact that the North American discoglossoid Ascaphus truei of Stejneger is still known by the type alone; and that the recently discovered Kaloula verrucosa Blgr., found only a few years ago in Yunnan, has been found still more recently in the province of Shantung.

Of fifty species of amphibians known from the island of Sumatra, seven, or fourteen per cent, seem to be peculiar to it. Van Kampen reports both Megalophrys montana and $M$. nasuta from Sumatra, though in Werner's comparative list, which we have spoken of before, the latter only is mentioned as being Sumatran, the former being Javan. Werner also includes $M$. hasselti in his list of species occurring in Java and Malacca, but not in Sumatra. Van Kampen, on the other hand, has $M$. hasselti from several definite localities in Sumatra, as well as in the Philippines, Borneo, and Java.

There remains to be mentioned Werner's record of Rana novae-brittaniae Werner, which has the very improbable distribution of Sumatra and the Bismarck Archipelago. It seems unlikely that this can be explained by suggesting accidental transportation. Perhaps it is more likely to be a case of convergence, where some similar form has by chance grown so like another as to be indistinguishable; but a misplaced label often is to blame for this sort of anomaly.

Rana hosii Blgr. occurs on Sumatra, Borneo, and Java, but not in the Malay Peninsula. Polypedates colletti (Blgr.) has the same distribution, likewise $P$ : otilophus (Blgr.), except that the former occurs also in Natuna; these two species do not, however, occur in Java. 
Two species of Nectes, $N$. pleurotaenia van Kampen, and $N$. werneri van Kampen, are confined to Sumatra and Borneo.

To sum up, then, we may say that the portion of the fauna of Sumatra under discussion shows nothing but a direct Malayan derivation, unless we except Dyscophina, whose ancestors may have died out, or are as yet undiscovered in Malacca. It has already been noted that those small islands which lie in the Indian Ocean off the coast of Sumatra, whose fauna has been derived directly from Sumatra, have not each of them the same common Sumatran species; and Werner has remarked that this is probably due to the fact that they have received their species by transportation from the nearest adjacent part of the larger island; and that one island may have received one typical Sumatran species, and another island another, simply because these species were confined to the particular parts of Sumatra which lay opposite the various islands. This I hold to be improbable. He goes on to note how ridiculous it is simply to record Sumatra without further data in keeping locality records of species collected on the island; for he assumes, with excellent reason, that probably many of the characteristic species are closely confined to certain areas on the island. Concerning this we have as yet very limited data; enough, however, to prove that it is probable.

Van Kampen has remarked, in a paper on the amphibians of Sumatra (Zool. jahrb. Syst., 1905, 22, p. 714-15), that there is no evidence whatever to be drawn from the distribution of Amphibia to show that there has been a connection between Java and farther India - through the Mentawei and Nicobar Islands - without connection with Sumatra. It may be remarked that the reptiles also bear out this statement; furthermore, as will be shown in the remarks on Java, Sumatra seems to have provided that island with the larger share of its Malayan forms - with the larger share of all its forms, in fact. There may have been a bridge of short duration between Borneo and Sumatra by way of the islands of Billeton and Banka, for it is to be noticed, that if the main mountain chain of Borneo were projected towards the southwest, it would reach and merge with the low mountains existing on these two islands, which lie directly between Borneo and Sumatra. The evidence, however, so far as the reptiles and amphibians go, is very far from being convincing.

NiAS.

Closely related to the problems connected with the herpetology of Sumatra, are those of the islands lying near by in the Indian Ocean. We have data re- 
garding the herpetology of three of these. They are Nias, Engaño, and one of the Mentawei Archipelago.

In $1885 \mathrm{~J}$. G. Fischer reported on a small collection of reptiles and amphibians from Nias (Abh. Naturw. ver. Hamburg, 1885, 9, 1, p. 3-9, 1 taf.). Four years later E. Modigliani contributed a fuller list with a bibliography (Ann. Mus. civ. Gen., 1889, ser. 2, 7, p. 113-124, tav. 1). Finally, van Lidth de Jeude described a collection of sixteen reptiles, three of which were new to Nias, and added a further bibliography (Notes Leyden mus., 1890, 12, p. 253-256). These three papers between them cover fully our knowledge of the local cold-blooded land vertebrates.

The island itself is not a large one, being only about seventy miles in greatest length by from twenty to thirty miles wide. It is about fifty miles distant from the nearest point of the Sumatran coast, and the charts show that it is more or less mountainous throughout. The strait does not show any great depth of water, though the soundings are few. These run from 20 to 47 fathoms, while in one spot we find $\dot{\overline{50}}$ ( $i$. e. no bottom at fifty). North and south of the island there are considerable depths of water, 376 fathoms just south between Nias and the Batu Islands, and 335 fathoms to the north, near the Banjak group. So it is very probable that the connection of this island with Sumatra has been direct and not through other islands lying either to the north or south of it.

The reptiles and amphibians are purely Sumatran; there is one fresh-water turtle. Fourteen lizards occur, of which one, Aphaniotis acutirostris Modigliani, is known only from Sumatra, Nias, and Mentawei; all of the others occur elsewhere as well as in Sumatra. Snakes on Nias are more abundant in number of species than either of the other groups of reptiles. There are no less than thirty-two species recorded, all of which except two occur in Sumatra. Three species are, so far as we know, confined to Sumatra and Nias. They are Oligodon trilineatus (Dum. \& Bibr.), Calamaria stahlknechti Stoliczka, and Enhydris albomaculata (Dum. \& Bibr.). The two species which occur in Nias and elsewhere, but have not yet been found in Sumatra, are Calamaria lumbricoidea Boie and Haplopeltura boa (Boie). These will probably be found in Sumatra when we know the island more thoroughly. The former species is known from Nias and Java; the latter from the Malay Peninsula, the Philippines, Nias, Borneo, and Java.

Nine amphibians occur upon the island, among them the burrowing Ichthyophis glutinosus (Linné), Bufo claviger Peters, which is confined to Nias and Sumatra, the small and delicate Microhyla achatina (Boie), and other species 
certainly not transported fortuitously. The fact that there are no species strictly peculiar to the island, and that these delicate subterranean amphibians are found upon it, proves conclusively that we can not consider Nias as an oceanic island, but that it has derived its fauna directly from that part of Sumatra which lies directly opposite to it - that is, between the equator and the second parallel of north latitude - by a land bridge, and not, as has been suggested, by accidental transport.

\section{Mentawei Islands.}

This group consists of the little-known island of Siberut in the north, and southward, Sipora and North and South Pagi. These four islands are all hilly, and are separated from Sumatra by deep water; one sounding of $835 \mathrm{fms}$., others of 640-350 fms., occurring on the charts published as Plate 7 of the atlas of the Valdivia report. North of Siberut the water is very shallow. According to the Dutch Hydrographic Bureau charts, a ridge extending to Tanahbala is covered by from 6 to $26 \mathrm{fms}$. only; the Valdivia chart, however, shows one sounding of $150 \mathrm{fms}$. Inside this ridge towards Sumatra there is a sounding of 417 fms., and outside, one of $206 \mathrm{fms}$. Tanahbala, Tanahmasa, and Pini Islands, the largest of the Batu Archipelago, are low-lying, and are separated from each other and from Sumatra by water only 12-26 fms. deep. An earlier connection, then, of the Mentawei Islands with one another is rendered highly probable by the hydrographic data.

We know the herpetology of but one of these islands, Sipora (also called Sereinu). In 1894 Boulenger (Ann. Mus. civ. Gen., 1894, ser. 2, 14, p. 613-618) reported on a collection made by the Italian naturalist Modigliani.

The same single fresh-water turtle which occurs on Nias is found also on Sipora. The lizards are twelve in number; of these, two, Sphenomorphus modigliani (Blgr.), and Leiolepisma vittigerum (Blgr.), have hitherto been found only on this island. The fact that this island is perhaps more isolated from Sumatra than is Nias may account for these two autogenous species of lizards, while Nias has none. It is very possible, however, that they will ultimately be found on Nias and Sumatra.

One lizard, Gonatodes kandianus, has a most strange distribution. It is found in India and Ceylon and in all the Sumatran coast islands as yet herpetologically explored,-- Nias, Sipora, Engaño,- but it has not as yet been found in Sumatra. This form may or may not exist in Sumatra; it probably does, though as yet unknown. 
The snakes in this case do not outnumber the lizards in multiplicity of species as they do on Nias. This, again, is undoubtedly due simply to the fact that we do not know the island thoroughly. There are eleven species known, none of which are peculiar to the island, nor are any of them otherwise of particular interest.

The amphibians, as with Nias, simply serve to emphasize the close Sumatran affinity of the fauna. It is interesting to note the presence again of Ichthyophis glutinosus. Four species of amphibians - namely, Polypedates appendiculatus, P. pardalis, Calophrynus punctatus, and Nectophryne guentheri - are all known from Sipora, but as yet none has been found in Sumatra. These forms are all known either from the mainland, or from Borneo and the Philippines; and it is almost certain that future investigation will show that they occur on Sumatra as well. Van Kampen has pointed out that three of the Sumatran frogs, viz.-Rana nicobariensis, $R$. labialis, and $R$. microdisca, were all known from small islands about Sumatra before they were found on the great island itself. It is remarkable that no Philautus (Ixalus) has been found on any of these islands off the coast of Sumatra or upon Sumatra itself, for we should suppose from the distribution of the genus that it would have been found there long ago. It is hardly conceivable that it does not occur. Its absence from the islands off the coast would surely seem to emphasize the fact that they have not served as a bridge between the mainland and Java, as has been suggested by some writers.

It is most unfortunate that no data are as yet available regarding the faunae of either Siberut or of the two Pagi Islands; and it is still more unfortunate that there are not sufficient soundings to establish definitely the presence or absence of a ridge connecting Mega with Engaño Island. Mega seems to lie on an extension of the same great submarine hook of which the Mentawei Islands are simply the parts remaining above the surface of the water.

\section{EngaÑo.}

The single small island of Engaño occupies the most isolated position of any of the islets off the Sumatran coast, for it is distant over a hundred miles from Mega, which may be considered the southernmost of the Mentawei group; the nearest point on the shore of Sumatra itself is distant about sixty miles. The island would appear to be similar in its physical characteristics to the ones which we have been discussing, though it is considerably smaller than Sipora, and far less in size than Nias. It is about twenty miles in length by ten to twelve in width. Unfortunately the soundings on the Dutch chart and on the 
map published in the report of the Valdivia expedition are mostly in places where they are of very little interest to us. Southeast of Engaño there are two soundings, one of 1,104 , the other of $732 \mathrm{fms}$; ; to the northwest a single sounding of $637 \mathrm{fms}$. is given; and northward in the Indian Ocean a depth of 2,744 fms. occurs. In a direct line between Engaño and the mainland of Sumatra, and between Engaño and Mega, no soundings have been made.

We know of the herpetology of the island through the collection of Elio Modigliani, which were reported upon in 1892 by Vinciguerra (Ann. Mus. civ. Gen., ser. 2, 12, p. 517-526).

A single fresh-water turtle, Cyclemys ambonensis (Daudin), is known. This is interesting, as in the other islands the single known fresh-water turtle is Cyclemys dhor (Gray). Assuming that the identifications are correct, and that there is only a single species on each island, this may prove to be an ultimate clue to a different origin for the fauna of Engaño from those of the other islands.

Of the lizards, Gymnodactylus marmoratus (Dum. \& Bibr.) occurs in Sumatra and Engaño, as well as elsewhere, though it does not occur on either Nias or Sipora. Lepidodactylus ceylonensis Blgr. has been found in Ceylon, Borneo, Java, and Engaño. Draco modiglianii Vinciguerra is peculiar to the island. Siaphos relictum (Vinciguerra) is known only from Sipora and Engaño. Altogether about nine species of lizards have been reported, less than from the other islands; but whether this is because it has been less carefully studied, is a question which only time will answer.

Among the snakes, Elaphe enganensis (Vinciguerra) is peculiar to the island, and only two other species have been recorded - one the free-swimming Hurria rhynchops (Schneider), the other the tree-snake, Psammodynastes pulverulentus (Boie).

I find in van Kampen's records but two amphibians, Rana macrodon Dum. \& Bibr., and $R$. nicobariensis (Stoliczka).

From the above it is evident that the facies of this fauna is quite distinct from that of either Nias or Sipora. Whether this is due to a longer isolation, or to our incomplete knowledge, it is impossible to say; and whether future soundings will develop closer relationship with the southern Mentawei Islands or with Sumatra itself, is a point of great interest. There is, of course, a possibility that this island never has been connected with the mainland, though the fauna, as we know it now, contains several species which it would be very strange to find on an oceanic island. The mere fact of the existence of a deep channel between Engaño and Sumatra, would not, however, necessarily pre- 
clude the possibility of a bridge having existed in the past between these two islands. Many similar cases are known at the present time where a recent land bridge has disappeared leaving a very deep channel. ( $C f$. Suess, Natural science, 1893, 2, p. 180-187).

\section{JAVA.}

Although we have not had within recent years a complete list, based on a large amount of material, giving us an up-to-date knowledge of the Javan reptiles ānd amphibians, still we have a multitude of data from many sources, so that we may say that Java is the most completely known of any one of the East Indies. Since the earliest times, when Kuhl, Boie, Bleeker, Schlegel, Edeling, and other Dutch naturalists began describing species, Java has attracted a host of naturalists, even to the present time, largely on account of its botanical gardens, the most beautiful and famous in the world. Many of these naturalists have made collections, so that the region about Batavia and Buitenzorg is the type locality for more East Indian species than any other. This is the region whence came most of the forms described by Boie in Isis, 1827. It is also one of the few islands where we have data regarding the vertical distribution of species, as well as the limits of their range within the island itself. In spite of the fact that it supports an enormous population - about thirty-five millions of people - and that it is only about the size of the state of New York, being about 550 miles long and from 60 to 120 miles wide, Java has considerable areas of wooded lowland, quite uncultivated, and many of the mountain slopes are covered with splendid forests of marvellous tropical luxuriance, so that, contrary to what one might suppose, reptiles are very plentiful upon the island. In the systematic account of collections we made there, notes are included which have a bearing on local distribution, as well as something regarding relative * abundance.

With so considerable a literature, it would be strange if erroneous records had not crept in; it is not strange, then, that in 1900 Werner wrote: "Was Java anbelangt, so hat diese Insel im Vergleich zu Sumatra schon ganz deutliche Anklänge an die Fauna der Molukken und theilweise sogar Papuasiens aufzuweisen; Draco lineatus, Lophura amboinensis, Tiliqua gigas, Cornufer corrugatus sind Beispiele hierfür."

Now, the mere fact that none of these species occurs on the Lesser Sunda Islands is sufficient to show that there is something wrong with the records. In the first place, it had long been supposed that Draco lineatus occurred upon 
Celebes, but Boulenger (Proc. Zool. soc. Lond., 1897, p. 206) has shown that the specimens referred to that species by Peters and Doria, Müller, and others, in reality belong to Draco spilonotus Gthr., while the specimens that have been referred to $D$. volans and $D$. maculatus should probably be referred to $D$. beccarii Peters and Doria. The Javanese record for $D$. lineatus is also undoubtedly a case of mistaken identity. Neither Dr. Stejneger nor I have been able to find the authority for the occurrence of Hydrosaurus (Lophura) on Java. It certainly is not known there either by the natives or resident Dutch naturalists, for I remember well the interest which the unpacking of some of my specimens from the Moluccas aroused in the natives about Buitenzorg and Batavia. The record for Tiliqua gigas is based on a specimen in the Berlin museum examined by Boulenger (Cat. lizards Brit. mus., 1887, 3, p. 145), and said to have come from Bantam. Of course, if this specimen ever came from Bantam, it was simply one which had been brought there by some Malay prau trading from the Moluccas. Years ago a considerable commerce went on in all sorts of live beasts, which ultimately found their way to the Sunda Straits, where in years gone by they were often bought and brought to Europe by the ships which at that time stopped there regularly for wood, water, and fresh provisions. Live specimens of this giant scinc are often captured and sold. The record for Cornufer corrugatus in Java was wisely questioned by Boulenger (Cat. Batr. Sal. Brit. mus., 1882 , p. 110). It is needless to add that the original report was never substantiated. Recently van Kampen has shown that Hyla dolichopsis (Cope) turns up occasionally in the Botanical Gardèns, accidentally brought in with specimens from Papuasia. This disposes of the last of the Papuan species supposed to occur in Java.

The fauna is purely Malayan, for the most part, probably wholly, derived through Sumatra, the total number of species being much less than in Sumatra, and curiously enough containing surprisingly few peculiar forms. The other element in the biota, so well known and so often discussed, is the presence of Malayan species which occur on the mainland, but not on either Sumatra or Borneo. Van Kampen has remarked that the number of these species will probably grow smaller, with which I concur; but there is a surprising number of such species now, including some mammals, birds, reptiles, and amphibians. Megalophrys hasselti, however, has been found on Sumatra recently, thus reducing this list by one species.

Of these mainland forms, Crocodilus siamensis Schneider, a rare species everywhere, has been reported from Siam, Cochin China, and Java. The last 
record is based on an example in the Senckenburg museum at Frankfurt on the Main. Werner (Zool. jahrb. Syst., 1900, 13, p. 504) does not doubt the accuracy as to the locality in view of the rarity of this species on the mainland, and the fact that we know so little of the estuarine fauna of all the islands. He emphasizes the fact that Tomistoma long existed undiscovered in both Sumatra and Malay, and even suggests that the Malayan Gharial may exist in Java. I must confess to a scepticism regarding the correctness of the data of the Frankfort specimen. Werner may be correct, but if so, why is the crocodile not quite as likely to occur in Sumatra, though as yet undiscovered? Geoclemys subtrijuga (Schlegel and Müller), the conspicuous and generally common Natrix piscator (Schneider), the showy rat-snake Ptyas mucosus (Linné), so often common about dwellings, and Dryophis xanthozona Boie, are all species known both from Java and the mainland, and one would suppose that they would be among the earliest to be discovered on Sumatra; but, so far as we now know, they do not occur there. Agkistrodon rhodostoma (Boie) has long been known from Java, and for years it was included in the Siamese fauna on the basis of a single specimen, said to be from Siam, preserved in the British museum. Within the last few years Messrs. Annandale and Robinson during their exploration of the Malay Straits discovered that it was quite plentiful in certain localities in the Malay Peninsula. ( $C f$. Boulenger in Fasciculi Malayensis, 1903, 1, p. 170-171.) It is hardly less surprising that this conspicuous snake should have been so long undiscovered in the Malay Peninsula than it would be if other species, equally conspicuous, should perhaps be still undiscovered in Sumatra - this species among them. The presence of Rhinoceros sundaicus, though comparable to that of Agkistrodon, is even more difficult to explain. The Sumatran rhinoceros, $R$. sumatranus, is well known, and occurs also on the mainland. It is difficult to believe that of two species of rhinoceros existing in Sumatra, only one should have been discovered up to now. Still this is probably the case, for we know as yet very little definitely regarding the various Malayan species of rhinoceros (see Flower, Proc. Zool. soc. London, 1900, p. 366-8). The cases of Tragulus stanleyanus, Viverricula malaccensis, and Helictus orientalis, all of which have been noted by van Kampen as having the same discontinuous distribution, may be considered as instances where specimens from the different localities would not be considered as identical species were plenty of modern material in hand for comparison; besides, their close relatives may easily exist in the highlands of Sumatra, which are as yet unexplored. Tragulus stanleyanus, I have been recently informed by Mr. G. S. Miller Jr., is a species certainly confined to the 
Malay Peninsula or a near by island. The type is old, without de finite locality and it cannot as now restricted be identified certainly with any particular species. One thing is certain, van Kampen was wrong in suggesting that the species ever came from Java.

Java has but six fresh-water turtles, considerably fewer than either Borneo or Sumatra.

There are thirty-one lizards known, but not a single one of these is of a genus not found elsewhere. Two genera, however, have the same distribution as the ophidian genus Elapoides. They are Harpesaurus, with one species each in Java and Sumatra,- - H. tricinctus (A. Dum.), and H. beccarii Doria,- and Dendragama, also with one species each in Java and Sumatra, namely, D. fruhstorferi Boettger, and $D$. boulengeri Doria. The two Javan species seem to be confined in their distribution to that part of Java lying nearest to Sumatra. Whether this is significant or not, it is difficult to say, as this happens to be the part of Java which we know better than any other.

Regarding Varanus nebulosus (Gray), Werner says: "fundort 'Java' sicher, Belegexemplar in Wiener Hofmuseum." In spite of this certainty, it is most probable that the locality of the specimen is incorrect, as it is known to be a wide-ranging, not uncommon form over much of southeastern Asia. Only two species besides the two spoken of above are peculiar to the island, in all only about twelve per cent.

The snakes are sixty-five in number, of which seven or eight (about eleven per cent) are peculiar to the island. As with the lizards, there is no autogenous genus. It is important to note the presence of the genus Pseudoxeonodon, with two peculiar species on the island, while no other congeneric form is known throughout the whole archipelago. Oligodon bitorquatus Boie has been reported from Ambon on the assumption that Rabdosoma amboinense Bleeker was a synonym of this species. There is probably no doubt with regard to its being identical; but, like so very many of Bleeker's records of localities for reptiles, it was in all probability based upon a Javan specimen, which in some way or other was credited to Ambon. This shuffling about of reptile localities was very characteristic of Bleeker's herpetological work, and it is obviously unsafe to place any reliance whatever upon them. It is quite impossible to conceive of a species being confined to Java and Ambon.

Regarding the occurrence of Brachyorrhus albus (Linné) in Java, it is probable that the case is similar to that of the preceding species. Schlegel (Essai phys. Serp., 1837, 2, p. 33-35) reports it as being excessively rare in Java, 
whence the early voyagers sent a few specimens. It has never been found there since; and as Boie and Kuhl both collected in the best known part of the island, that is about Batavia and Buitenzorg, it is almost certain that the specimens which they sent home came from the Moluccas, probably either Ternate or Ambon, and not from Java at all, else it would have been found there within the last half century.

Of the amphibians, nine of the thirty-four species, or about twenty-seven per cent, are peculiar. There is here also a genus Nyctixalus, with a single species not found elsewhere. The presence of Philautus (Ixalus) itself, with two species peculiar to the island, has been spoken of elsewhere in remarking their absence from Sumatra and the Mentawei Islands. Rana grunniens Daud. has been reported from Java and Ambon, another example of what happened in the days when these were the only two localities frequently visited by naturalists, and when collections were not kept separate as to locality with the care which is considered requisite at the present time.

In conclusion, then, we may say that the entire herpetologic fauna of Java is as purely Malayan as is that of Sumatra or of Borneo, and that evidence is wanting at the present time which will help us to explain the presence of a large and important series of species which are common to Java and the Malay Peninsula, but are not found in either Borneo or Sumatra. Whether a-land connection did once exist, perhaps through Banka and Billeton, is a question which can be settled, if at all, only by the careful study of the herpetology of these two islands, which has not yet been made. It seems really more probable that our incomplete knowledge of the fauna of Sumatra is to blame for this most anomalous condition.

\section{BORNEO.}

Borneo, larger than Sumatra, in fact the largest of all the East Indies with the exception of New Guinea, has a reptilian fauna as truly Malayan as any of the other islands, though the amphibians show some rather anomalous conditions.

Robert Shelford in 1901 (Journ. Str. Br. roy. Asiat. soc., 1901, p. 43-68) published a list of the reptiles known to occur upon Borneo, not including the islands zoögeographically dependent from it, such as the Natuna and Palawan groups of islands. In this list, which we may use about as it stands, he has omitted the record of Macropisthodon rhodomelas (Boie), which Flower recorded from Borneo (Proc. Zool. soc. London, 1899, p. 605); on the other hand, he has 
recorded two species of tortoises, Orlitia borneensis Gray and Brookeia baileyi (Bartlett), both of which together with Liemys inornata Blgr., must be considered as really representing only one species, Orlitia borneensis Gray.

His list shows a total of 212 species, of which sixty-four are peculiar to the island; while the table which I have prepared (see p. 169-203) show 207 Bornean species, of which sixty-five are peculiar to the island; so that, as will be seen, our results are very close. The fact that only small changes have been made necessary during the last decade would seem to indicate that our knowledge of the fauna of Borneo is approaching completion.

In 1895 Robert Bartlett published a list of the reptiles of Borneo in the Sarawak gazette, 25. This list I have been unable to consult, and so I have been unable even to estimate the validity of some of the species which he proposed; e. g. his Lygosoma kinabaluensis I know only by name, and I am unable to discover anything regarding its identity, as Shelford, for one, omits all reference to it.

To sum up these species in the same way as we have done for other islands, we find fifteen fresh-water tortoises, none of which are peculiar to the island, and two crocodileans, the wide-ranging C. porosus and Tomistoma schlegelii, of which we have spoken before. The lizards are seventy-six in number, of which thirty species, or forty per cent, are confined to Borneo. Lanthanotus restricted to Borneo, as has been so satisfactorily pointed out by Boulenger, has its nearest relatives in the two species of Heloderma occurring in southwestern United States and Mexico. This form is probably fast dying out, as its relatives have in the past died out over most of the rest of the world; the species is now so rare that we know of only two specimens, one in the museum at Kuching, Sarawak, and the other, the original type, in Vienna.

It is very interesting to note in Borneo the presence of two species of Japalura, one, $J$. ornata confined to Borneo itself, the other, $J$. nigrilabris, known only from Borneo and the Natuna Islands. These are the only species of this genus which occur amongst the East Indian Islands, though of course, as is well known, there are other forms which are peculiar to Formosa, to the Riu Kiu Islands, and Botel Tobago. On the mainland the genus has a range from the Himalayas and eastern Bengal through Assam to west China. No species is known from the Malay Peninsula.

Of the snakes there are 116 species, of which thirty-five species, or thirty per cent, are not found elsewhere. The four genera, Hydrablabes, Lepturophis, Oreocalamus, and Idiopholis occur nowhere else. Another genus, Agrophis, 
is of great interest in that it affords the only case in herpetology of species showing close relationship between Borneo and Celebes. The genus is known from two species only, one on each island. This impossible condition is, of course, only explicable if we consider that the species must either occur elsewhere undiscovered or else have previously been of wider range and died out everywhere except upon these two islands. As both Borneo and Celebes share each a considerable number of species with the Philippines, it may be that upon this common ground Agrophis occurs, or may have occurred, in the past. Gonyophis margaritatus is known from the Malay Peninsula and Borneo only, as is also the genus Aeluroscalabotes among lizards.

The amphibians are more unlike those which we know from the Malay Peninsula than are the reptiles. The number occurring on Borneo is very great. Van Kampen in his tables gives seventy-eight species, a far greater number than is known from any other island. The peculiar genera are Oreobatrachus and Colpoglossus, the latter a monotypic genus of Dyscophidae, the former a monotypic genus of Ranidae, confined as far as known to Mt. Kina Balu. Species of Calophrynus and Nectophryne occur, both of these genera having widely discontinuous distributions. It seems probable that when they are revised on anatomical grounds, they will be found related, though probably perfectly easily separated. It seems hardly possible for a genus to occur in Africa and in the East Indies and still maintain its generic unity, when it has probably slowly disappeared from the enormous region lying in between.

Borneo resembles the rest of the Greater Sunda Islands in the absence of Hylidae; but shares with New Guinea the engystomatid genus Chaperina, the species C. fusca being recorded from both Borneo and Papua, but as yet undiscovered on the islands that lie between, though three other congeneric species occur upon New Guinea itself. Van Kampen has published some notes - of interest on the probable dispersal in the past of the members of this family, and especially regarding their astonishing abundance on New Guinea ( $c f$. remarks on van Kampen's papers under "New Guinea"). The presence of Cornufer on Mt. Kina Balu (C. baluensis) is of interest as being a close parallel to the distribution of Chaperina, except that Cornufer corrugatus has been recorded from the Philippines.

Of the seventy-eight amphibians mentioned as occurring on the island, thirty species, or twenty-nine per cent, are peculiar to Borneo. Before closing, it may be of interest to mention the fact that Rana everetti occurs on Borneo, Celebes, and the Philippines, thus having such a distribution as we might have 
supposed the ophidian genus Agrophis had, while Rana baramica is confined to Borneo and Banka.

There does not seem to be any reason to suppose that Borneo has been connected with the Lesser Sunda chain as has Celebes. The Papuan element in the fauna may well have been derived from the Moluccas through connections which included some of the southern Philippines.

\section{Lesser Sunda Islands.}

In this group may be included the islands from Bali to Timor, or rather such of them as we have data concerning. Collections have been reported on from comparatively few of the islands; therefore the presence of many characteristic forms on one island, and their absence on another near by, show at once how very incomplete our knowledge still is of all these islands, except Timor, which has been more or less studied and collected upon by both Dutch and Portuguese naturalists for many years. The islands of which we know something, as to the herpetology, are Lombok, Flores, Ombaai (or Alor), Sumba, and Timor; the islands of Savu, Semao, and Rotti, close to Timor, are also partially known. The great island of Sumbawa is absolutely a terra incognita, as is also the important island of Bali, of which we have only one or two records of common wide-ranging species. The smaller islands of Adonare, Lomblen, Pandi, Kambing, and Wetter, are herpetologically entirely unexplored.

With the exception of Timor, none of these islands shows any startling conditions which would serve to separate it from the others zoölogically. Their fauna is almost exclusively Malayan, and there is no evidence whatever on the herpetological side in support of the existence of what is known as Wallace's Line between Bali and Lombok. There is a distinct Australasian tinge to Timor. The Lesser Sunda Islands show species, sometimes known from one of them, sometimes from another, which are common to both Java and Celebes, but which are unknown on Borneo. What has been termed the Flores Bridge is now one of the most satisfactorily established of all the land connections which have been suggested in this area. It is evident that Celebes has received from this Sunda group a very large portion of its herpetologic fauna; among some of the species which may be mentioned as having utilized this Flores Bridge the following is typical - Rana microdisca is known from Sumatra, Java, Flores, and Celebes. A large number of other species, which will be spoken of under the note on Celebes, have without doubt used this same connection, for these species have long been known both from Java and from Celebes, but owing to the fact 
that our knowledge of the fauna of these islands is very incomplete, have not yet been found on any of the Lesser Sunda Islands.

The Sarasins have postulated a second bridge to account for such distributions as these, of which there are a considerable number. They propose a Java Bridge, connecting Java and Celebes, as well as a Flores Bridge, extending from Flores to Celebes.

That the Lesser Sunda Islands remained connected with one another after their separation from Java and Celebes seems probable, because we find a considerable number of species which are peculiar to the group and occur upon more than one island.

Only two turtles are known from the area:-one, from Timor, distinctly Malayan in its origin, is described as a subspecies of Amyda cartilaginea, but it is probably specifically distinct, and may be known as A. newtoni Ferreira; the other is Chelodina novae-guineae, which has been reported by van Lidth de Jeude from Rotti, a small island almost a part of Timor.

Crocodilus porosus is the single crocodilean in the region; so far we know it is from Timor only, though there is no reason to suppose that it does not occur upon the other islands.

Lizards are recorded from the various islands as follows:- from Bali, a single species, the wide-ranging and common Cryptoblepharis boutonii; from Lombok seven; from Flores, eleven; from Ombaai nine; from Timor el even; and from Sumba eight.

The following lizards are peculiar to this group of islands, and are not confined to a single island:-Draco timorensis occurs on Timor and Ombaai, adjacent islands; Sphenomorphus florensis occurs on Flores, Ombaai, and Timor, three islands which form an almost continuous series; S. emigrans occurs on Flores and Sumba, again a case of adjacent islands. Varanus timorensis, on the other hand, has a widely discontinuous range; while originally described from Timor, it has since been found in Queensland, but, so far as is known, does not occur elsewhere.

The genus Gonyocephalus is absent from all these islands, though species are known from both sides of the region, viz. from the Greater Sunda Islands, and from New Guinea; this anomalous condition is probably to be explained by the fact that the distribution took place through land bridges which include some of the Philippines, where species also occur, so that the dispersal of this genus had nothing to do with the region under discussion.

Of snakes, again, we know from Bali only a single, common wide-ranging 
form, Hurria rhynchops, while from the other islands we have records as follows: - from Lombok seven; from Flores nine; from Ombaai five; from Timor sixteen and from Sumba seven. Typhlops polygrammicus has a distribution similar to that of Varanus timorensis, except that it is recorded from various parts of Australia instead of being confined to Queensland. Liasis fuscus, a species of a Papuasian genus, occurs on Timor and also in British New Guinea and Queensland; L. macloti is found upon Timor and the two small islands of Savu and Samao, lying near by. Python timorensis occurs on both Timor and Flores. Naia naia, using the name in its broad sense, has been found in this group on both Flores and Ombaai. The distribution of the genus Calamaria, so far as it goes, resembles that of the saurian Gonyocephalus; and although members of the genus occur on Java on the one side, and in Celebes to the north, not a single one has been reported from this group of islands. Here again the genus is reported as existing on the Philippines. The genus Cylindrophis has a somewhat peculiar distribution. The records which I have found are as follows:- from Burma, Cochin China, Siam, Malay Peninsula, Sumatra, Borneo, Java, Celebes, and Batjan, but on neither the Philippines nor any one of the Lesser Sunda chain. A single peculiar species, however, occurs on Lombok and another in Djampea; they are respectively $C$. opisthorhodus and $C$. isolepis, so that the distribution is not in reality a discontinuous one after all.

So far as known, comparatively few forms are confined to a single island. Thus, we know only two peculiar lizards on Flores; three on Timor and one on Sumba. None has been described as peculiar to Bali, Lombok, or Ombaai. Among snakes there is one strictly peculiar species each upon Lombok, Flores, Timor, and Sumba.

Regarding the amphibians, I take van Kampen's records directly as they stand; though he bases several of them, as he himself remarks, only upon Bleeker's notoriously inaccurate reports. We find the following:- upon Bali, two species; upon Lombok, five; upon Flores, six, with one peculiar species; upon Ombaai, two; Timor, three; and Sumba, three. Of peculiar interest is the single species of Sphenophryne, S. monticola, which is confined to Lombok. This distinctly Papuan genus occurs elsewhere, outside of New Guinea, only upon Djampea and Celebes, where two species occur. This is another excellent piece of evidence of a land connection, though it does not, of course, necessarily suggest a direct connection between Celebes and Lombok; it may be mentioned, however, that the long string of Paternoster or Tenga, and Postillon or Sabalana Islands stretch in a direct line between Lombok and Celebes. Hylidae, absent 
on the Greater Sunda Islands, and also on Celebes, are present in this group, one species, Hyla everetti, being confined to Ombaai, Timor, Savu, and Sumba; while the Papuasian, $H$. dolichopsis, has been reported from Timor, though it must be confessed that the same form has also turned up recently on Java as an accidental immigrant; it is not, however, as likely to have been accidentally introduced into Timor.

Since the preceding pages were written I have received the report on the reptile and amphibian collections of the Elbert-Sunda-Expedition des Frankfurter Vereins für geographie und statistic by Jean Roux. Three new species are described:- Typhlops elberti Roux from Lombok, and Cylindrophis boulengeri Roux, and Rana elberti Roux from the island of Wetter. This island remained hitherto unexplored herpetologically, although the birds have been made known by Rothschild's collectors. Aside from these interesting novelties the paper records most important additions to the knowledge of the extension of the fauna of southern Celebes to the islands of Kabaeüa and Buton. This condition was exactly what might have been expected. From the island of Wetter, besides the new species, six other reptiles were recorded, all species wide ranging throughout the Archipelago except Sphenomorphus florensis (M. Weber), which does not range beyond the limits of the Lesser Sunda chain. On this island only two amphibians were found; a new subspecies, or island race, of Rana tigerina, called verruculosa Roux, and the new Rana elberti Roux.

From Lombok came the greatest surprises, which prove that, so far as reptiles are concerned, the island is faunistically as Malayan as Bali. Among the new discoveries were Gekko gecko (Linné), Draco volans Linné, Dibamus novae-guineae Dum. \& Bibr., Gonyosoma (called Coluber) oxycephala (Boie), Elaphe (also called Coluber) subradiata (Schleg.), and Naia naia (Linné). The addition of these to the list of species already known goes far to enable us to form a more accurate idea of the existing conditions on this most important island.

Among Amphibia we are most surprised to find Rana macrodon Dum. \& Bibr. and Rana modesta Blgr. existing on the same island. I had supposed that the latter species was a derivative of the former, which had replaced the parent species after isolation on Celebes. The individuals of $R$. modesta may have got to Lombok by the Celebes-Lesser Sunda Bridge and then met again the parent species, which had come earlier from Java to Lombok and remained specifically unchanged upon that island. Thus $R$. modesta probably came by the same route and contemporaneously with Sphenophryne. If earlier, it might con- 
ceivably have found its way back to Java again, whence its original ancestors came, by the direct bridge to Celebes. I have separated a Lombok specimen of Bufo biporcatus Tschudi under the name of Bufo cavator. I note that Roux makes no such separation. Other important records of Amphibia from Lombok are Bufo celebensis Gthr., and Polypedates leucomystax (Gravenhorst). The other locality visited by Elbert was Sumbawa, an important member of the Lesser Sunda group, herpetologically another terra incognita. From this island ten species of reptiles were obtained, none of them new or of particular importance from a zoögeographic point of view. Rana tigerina Daudin and Rana microdisca Bttgr. were the only species of Amphibia taken.

\section{Celebes.}

We have more accurate information regarding the zoögeographical relationships of Celebes than of any other island in the entire archipelago. This is almost entirely due to the remarkable collections, and studies based upon them, by the cousins, Drs. P. and F. Sarasin. The third volume of their work on "Celebes," in which they have published the results of their trip, is entitled "Ueber die geologische geschichte der Insel Celebes auf grund der thierverbreitung" (Wiesbaden, C. W. Kreidel's verlag, 1901). It contains a very full and graphic explanation of the previous connections which, in their opinions, Celebes has had with near by islands, and serves to show more fully than any other work that has ever been published, how satisfactory a basis faunistic studies form for the interpretation of geologic history. The explanations of the Sarasins will be used in the general summary.

To turn directly to the reptiles and amphibians of the island, we may base our notes on "A catalogue of the reptiles and batrachians of the Celebes, with special reference to the collections made by Drs. P. and F. Sarasin, 1893-1896." This is by Dr. G. A. Boulenger (Proc. Zool. soc. London, 1897, p. 193-237, pl. 7-16). There are eighty-three reptiles and twenty-one amphibians recorded from the island; thirteen lizards and sixteen snakes, or about thirty-six per cent of the total number, are peculiar to it.

Among these, however, there is but one endemic genus, Rhabdophidium. Among the amphibians eight, or about forty per cent - a very considerable proportion - are restricted to Celebes.

Generally speaking, the relation to the western islands has been pointed out by Boulenger to be much more intimate than that to the eastern islands; 
however, Papuasian affinity is shown in the presence of two peculiar species of the engystomatid genus Sphenophryne. The fact that scincids predominate in the fauna of the island, the number of species being larger than that of any other family, points at once to a more strongly eastern relationship of the fauna than one would at first sight realize; for many of the species are peculiar to the island, and as such do not figure in the counts of species known from either east or west. Thus, considering the enormous predominance of the members of this family in New Guinea, for instance, as against their extreme paucity in Java or Sumatra, the presence of fourteen species of what may be broadly termed Lygosomas serves at once to emphasize this eastern affinity. Some species, as Natrix vittata and $N$. chrysargoides, as also Calamaria calamaria, are found on Java and Celebes, but upon none of the islands of the Lesser Sunda chain. To this category also belong $C$. virgulata and Typhlops ater; whereas among amphibians, Rana microdisca occurs on Celebes, on Java, and in the Mentawei group. Examples of such distribution as this among the various groups of animals have been made the basis for what the Sarasins call their Java Bridge; they maintain that this connection was direct, and had nothing to do with the Lesser Sunda chain. In other groups of animals, however, distributions point directly to a bridge with this chain, and Flores has been accepted as the island to which the connection most probably led, so that this has come to be known as the Flores Bridge. Whether, however, in the light of the very little which is known of the herpetology of most of the Lesser Sunda Islands, the distribution of reptiles and amphibians bears out the distinctness or even the existence of both of these bridges, it is difficult to say. Special relation to the Philippines is shown, as Boulenger has pointed out, by a considerable number of other species.

This brings us directly to another point which is of considerable interest, viz. - the localization within Celebes of the distributions of various species. We should expect the forms having closest relationship with the Philippines, for instance, to occur especially on the Minahassa or northern peninsula of the Island. This is not very strongly brought out, however, by the data at hand; to be sure Dendrelaphis terrificus does occur in this locality only; on the other hand $R$. microdisca occurs also only on the Minahassa, though it is a species which we have spoken of as occurring elsewhere only in Java and the Mentawei Islands. Any other of the local distributions, so far as we know them, are equally anomalous; but we may readily imagine that a further special collection in herpetology may change this. 
Trmor-LAUt.

Before proceeding to consider the various islands of the Moluccan groups, it is proper to notice the herpetology of a small archipelago which presents a rather anomalous condition. The Timor-Laut or Tenimber group lies about two hundred miles almost directly eastward of Timor and about the same distance to the north of Melville Island off the coast of northern West Australia. While the charts are deficient in soundings, they lead one to suppose that the island is completely surrounded by water of great depth, from 200 to 900 fathoms; there are, however, no soundings on a direct line between Babar, Dawera, and the small islands Selu, Wariari, and Sera, which lie off the west coast of Jamdena, the largest island of the Tenimber group.

We owe our knowledge of the herpetology of this island to the collections of $\mathrm{H}$. O. Forbes. Boulenger reported on "The collection of reptiles and batrachians from the Timor-Laut Islands, formed by Mr. H. O. Forbes" (Proc. Zool. soc. London, 1883, p. 386-388, pl. 41-42). The reptiles are so few in number that it may be well to mention each species.

As might be expected, the Gekkos are wide-ranging forms, though it is interesting to see that Gekko gecko (Linné) reaches here the eastern limit of its range. It occurs also on both Timor and Celebes. Peropus mutilatus (Wiegm.) Varanus indicus (Daud.), and Cryptoblepharus boutonii (Desj.) also were found, all wide-ranging forms.

So far as we know, the scincids are but three in number, wide-ranging, and generally Papuan in relationships. They are Riopa rufescens (Shaw), Emoia cyanurum (Less.), and Dasia smaragdinum (Less.). The first mentioned may prove to be an autocthonous species, as Boettger has separated the Halmahera Riopa as $R$. mentovarium.

The agamids are very interesting. One of these is Physignathus maculilabris Blgr. This species belongs to a genus which occurs in Australia, TimorLaut, and the Indo-Chinese Peninsula. The Tenimber species is closely similar to $P$. gilberti (Gray) from Australia. The other agamid is Calotes cristatellus Kuhl, which ranges from the Malay Peninsula through most of the islands as far as Mysol. The representatives of this species on the islands from Celebes eastward may be referred to a subspecies, moluccanus Lesson; while those on Celebes seem to be similarly recognizable, and may be known by the race name celebensis Gthr.

Among the Ophidia we have with Python reticulatus (Schn.) evidences of 
this sharply defined, two-fold origin, another species reaching here the eastern limit of its range; while Holarchus forbesi (Blgr.) is the sole representative of this typical Malayan genus east of Java. Such a genus, the species of which are generally small and inconspicuous, with more or less subterranean habits, may of course exist on the comparatively little-known islands of the Lesser Sunda group. Dr. Boulenger writes to me that there can be no doubt as to this Moluccan Holarchus, as it has been recently rediscovered by Mr. J. d'A. Pareira.

Chrysopelea rhodopleuron Boie is confined to the Moluccan groups, but has Malayan affinities; while Python amethystinus (Schn.), Enygrus carinatus (Schn.), and Dendrophis calligaster Gthr. are all obviously of Papuan origin.

The only three amphibians recorded are Rana papua Lesson, and Hyla dolichopsis (Cope), both from New Guinea, and what van Kampen calls Hyla rubella Gray. This is an Australian species related to Hyla congenita Peters and Doria. Van Kampen had but a single bleached specimen, and some doubt is justifiable as to which of these species he really had.

\section{Ambon.}

We begin considering the true Moluccas with Ambon (or Amboyna, as it was formerly called), not on account of its importance geographically, but because of the fact that it was one of the earliest settlements in the East Indies, and that collections have been made there since the very earliest times. Lying near by is the larger island of Buru, and just northward of this isle are the three islands of the Sula (Xulla) group. Their names are Taliabou, Mangola, and Sula Besi. Of these three islands we know practically nothing, Buru being better known as to its birds and some other groups. This forms the most important region for investigation in the whole archipelago. A glance at the chart shows that, without the shadow of a doubt, the Sula Islands formed the site of the bridge which connected Celebes with the Moluccas on the one hand and with New Guinea on the other. To use a single example, we may emphasize the fact that the very distinct and highly specialized genus of swine which we call by the Malayan name of deer-pig or Babirusa occurs on Celebes, the Sula Islands, and Buru, and not elsewhere.

We have not considered all of the northern Moluccas at one time for the reason that they differ very widely from one another in the relationships of their faunae. With the exception of the island of Halmahera, none of them have been fully explored, and one can speak of their relationships only in a tentative sort of way, making use of the definite records which we have and leaving out of 
account altogether numerous forms which without doubt occur, but which have not as yet been found in modern collections where careful data have been preserved.

It may be well to caution students here against the frequency with which species of the most improbable occurrence have been recorded in the past from the two ancient settlements of Ambon and Ternate. In speaking of Java we had occasion to mention how recently it had been supposed that there was a Papuan element in the fauna there; and the occasion for such supposition was based on just such records as these of which we complain here. Bleeker was the chief offender in this direction. No further excuse is needed for disbelieving Bleeker's records than the fact that in 1860 he recorded Calamaria calamaria, Ptyas korros, and Natrix subminiata all from Wahaai, Ceram, as well as a host of other species equally impossible, from Ceram and other islands near by.

Ambon possesses a single fresh-water tortoise, the wide-ranging Cyclemys ambonensis (Daudin), and this species is also found on Buru. Crocodilus porosus Schn. is also reported from the former island.

Lizards are few in number. The wide-ranging Lepidodactylus lugubris (Dum. \& Bibr.) occurs, as well as two species of Gekko - the Malayan G. monarchus (Dum. \& Bibr.) and Papuan G. vittatus Houttuyn, the latter reaching here the western limit of its range, though occurring also on Buru. Another Malayan derivative is Draco lineatus Daudin, the sole representative of the genus in the Moluccan region. It has a circumscribed range, being at present known from only four islands:- Ambon, Buru, Ceram, and Mysol. The latter island we shall consider separately later on. It should be particularly noted here that, in spite of the careful collecting on Halmahera, no Draco has been found there.

Calotes cristatellus Kuhl is found on most of the Moluccas, both Ambon and Buru being in the list. Varanus indicus (Daudin), another wide-ranging form, is found on both islands. The Papuan Tiliqua gigas (Schneider) occurs on Ambon, but not on Buru, as does also Dasia smaragdinum (Lesson). The writer, however, saw what he was quite sure was this species, at Tifu in Buru, though no other record exists, and the specimen unfortunately was not taken.

Leiolepisma fuscum (Dum. \& Bibr.) and L. novae-guineae (Meyer) both occur on Ambon. Emoia cyanurum (Lesson) is reported from both islands, and $E$. baudinii (Dum. \& Bibr.) is reported from Buru, but not from Ambon.

Boettger, in reporting on Kükenthal's collection from Halmahera, separated specifically a number of scines which had previously been supposed to be wideranging forms, and as yet we do not know just how widely distributed these are 
in the Moluccas. For this reason, without material at hand for comparison, it is impossible to say whether the Riopa occurring on Ambon is Merrem's R. rufescens, long known from New Guinea and Queensland, or whether it represents $R$. mentovarium (Boettger), hitherto found only on Halmahera, and replacing there $R$. rufescens, which was previously reported from that island. Boulenger in a recent letter has written me that specimens from Ambon are different from those from Halmahera. Specimens from Ceram, Obi, and other neighboring islands, however, still require close comparison.

Cryptoblepharus boutonii (Desj.) occurs also on both of the islands.

A list of the snakes follows:-

Python amethystinus (Schn.), of Papuan derivation.

$P$. reticulatus (Schn.), of Malayan derivation.

Enygrus carinatus (Schn.), of Papuan derivation.

Brachyorrhus älbus (Linné), of Papuan origin.

Stegonotus modestus (Schlegel). Boulenger writes me that Ambon specimens can not be distinguished from Papuan.

Oligodon bitorquatus Boie, a Javan species, like others omitted here, and probably erroneously reported from Ambon.

Hurria rhynchops (Schn.), a freely swimming form of Malayan origin.

Boiga irregularis (Bechstein), specifically Papuan in origin, occurring throughout the Moluccas. The genus Boiga is, of course, Malayan, as is also Python.

Chrysopelea rhodopleuron Boie, Moluccan representative of a Malayan genus.

Of the amphibians, Rana grunniens Daudin has the same impossible distribution mentioned before, Java and Ambon.

Phrynomantis fusca Peters is found only upon Ambon and Batanta, and is probably incorrectly placed in this wholly African genus. Hyla amboinensis Horst is confined to Ambon and Mysol. H. dolichopsis (Cope), a wide-ranging Papuan species which, as we now know, has been transplanted by human agency as far as Java, occurs also on both islands.

To sum up in a few words the conditions here, we find that, in spite of geographic proximity to Papua, we are still in what may be called the transition zone. Timor-Laut, these islands of the Moluccas, and even, as we shall show later, Mysol, all have a number of Malayan forms, as well as generally even more Papuan forms, which are the ones we should expect to predominate to a greater extent than is actually the case. We are now, to be sure, on the extreme limit of the true Malayan herpetological fauna; and, although it is so conspicuous 
throughout the Moluccas, varying, it is true, among the different groups, only one or two Malayan species at most reach the mainland of Papua. Yet there are many genera which are characteristic of the western islands represented by well-defined peculiar species of local origin.

\section{Ceram.}

Certain peculiarities regarding the fauna of this island make it necessary to speak of it separately, and to include it neither with Ambon or Buru on the one hand,- though it would seem to be intimately related to Ambon hydrographically,- nor with the Halmahera group, from which it is separated by a wide and deep channel, on the other hand. The island itself is of considerable size and, so far as its reptiles and amphibians go, is incompletely explored. The interior is mountainous, and still inhabited by many tribes as yet unsubdued by the Dutch and dangerous to the traveller. It is about 200 miles long, and varies in width from twenty-five to fifty miles. It is connected by numerous small islands, which are separated from each other by what appear to be shallow channels,- though here again plentiful soundings are wanting, - with the $\mathrm{Ke}$ Islands, which lie to the southeast. It is along this route that an ancient connection with New Guinea may have existed. There may have been a double bridging here, to Ke, on the one hand, and on the other to Mysol.

There are no tortoises recorded from the island. Crocodilus porosus Schn. is said to occur, though no record of it has been published, so far as I know. I have, however, myself seen the tracks of crocodiles in the mud in mangrove swamps on the south coast of Ceram, and there is no doubt as to their being of this species. Omitting the older and doubtful accounts of Bleeker, we find few recent definite records. They are as follows:-

Of saurians these - Gekko vittatus Houttuyn, a Papuan form.

Draco lineatus Daudin, a Moluccan representative of a Malayan genus. ${ }^{1}$

Calotes cristatellus Kuhl, Malayan in origin.

Varanus indicus (Daud.), Papuasian.

Tiliqua gigas (Schn.), Papuan in origin.

Mabuya multifasciata Kuhl., a Malayan form.

Dasia smaragdinum (Lesson), wide-ranging throughout the whole archipelago, but probably Papuan in origin.

Leiolepisma fuscum (Dum. \& Bibr.), Papuan.

${ }^{1}$ Werner, in a recent paper (Mitt. Nat. mus. Hamburg, 1910, 23, p. 20), has recorded Draco timorensis Kuhl, from Ceram. This is most surprising and needs confirmation. 
Lygosoma muelleri (Schlegel), Papuan; reported also from Ternate by Peters \& Doria; this record, however, needs verification, as the species was not found by Kükenthal in his extensive collecting on Ternate and Halmahera, nor had other collectors found it there up to the time Boettger wrote his account of the Kükenthal collection. I showed a Ceram specimen of $L$. muelleri to many intelligent natives of Ternate, including indeed Ali, the faithful companion of Wallace during his many journeys, now an old man, and all agreed that they had not seen such a lizard before.

Dibamus novae-guineae Dum. \& Bibr., a burrowing form, which has been found sporadically from the Malay Peninsula to New Guinea.

Of Ophidia these - Typhlops braminus (Daud.), almost omnipresent in the eastern tropics.

Python amethystinus (Schn.), Papuan.

$P$. reticulatus (Schn.), Malayan.

Enygrus carinatus (Schn.), Papuan.

Natrix elongata (Jan.), confined to this island.

Stegonotus cuculatus (Dum. \& Bibr.), Papuan; found also in Queensland. It occurs on Ceram alone, of all the Moluccas.

S. modestus (Dum. \& Bibr.), Papuan.

Dendrophis pictus (Gmelin), Malayan.

Hurria rhynchops (Schn.), wider-ranging, semi-aquatic.

Fordonia leucobalea (Schleg.), of the same habits as Hurria.

Boiga irregularis (Bech.), Papuan representative of a Malayan genus.

Chrysopelea rhodopleuron Boie, a Moluccan representative of a Malayan genus.

Pseudelaps muelleri (Schl.), a Papuan species found on this island alone, of all the Moluccas.

Acanthophis antarcticus (Shaw), a Papuan species found west of New Guinea only on Ceram and the Ke Islands.

Of amphibians fewer still have been recorded. Hyla dolichopsis (Cope) occurs, as it does on many other islands near by. H. vagabunda Peters and Doria has been found, west of New Guinea, on this island alone. H. kampeni Barbour is, so far as known, confined to this island. Cornufer corrugatus (A. Dum.) occurs in Goram, whence specimens have just been received, and so probably on Ceram also.

It will be seen by examining these lists that both among reptiles and amphibians there are Papuan forms which have not been found upon any other of the 
Moluccas than Ceram, even though this island is one of the least known. There can be no doubt about these records, as I have taken several of the Papuan species myself, both at Wahaai on the north coast, and at Piru on the south, and several other collectors have also reported them. This strong and peculiar Papuan element can only mean that the connection of New Guinea with Ceram was independent of its connection with the other islands. As yet there are hardly sufficient soundings to indicate where this connection lay, though the fact that Acanthophis antarcticus (Shaw) also occurs on the Ke Islands, and the close hydrographic relationship of Ceram of this group through the chain of small islands already referred to would suggest that there had certainly been a connection with Papua by way of the Ke islands. Nevertheless the Ke Islands are very far from having such a typical Papuan fauna as the Aru Islands have. Then, too, the fact that Draco lineatus Daud. occurs on the island of Mysol, of which I shall speak separately, suggests a different route of migration. Possibly both bridges have existed, though at different geologic periods.

\section{MYsoL.}

If there was any reason for drawing a line such as Wallace proposed between Bali and Lombok, as a faunal limit, such a line might well be passed between Mysol and New Guinea. For the Malayan fauna may be followed as far as this island, which is the ultimate station to which Malayan species have extended specifically unchanged. The island does not, however, form a western boundary of the Papuan fauna.

This small and rather isolated island is separated by a shallow sea from New Guinea, the nearest large island, the strait being not more than forty-five or fifty miles wide, and from 8 to 25 fathoms in depth. It is separated also by what is apparently comparatively shallow water from the small islands of Kofiau, Kalap, Popa, and others which reach out towards the southern extension of Halmahera, this island itself being distant some hundred miles in a northwesterly direction. Southward of Mysol, between it and the nearest point of the island of Ceram - a cape near Wahaai - there intervene about 55 miles of what appears to be indeed deep water. Two soundings in this immediate region give 462 and 673 fathoms respectively, and just to the eastward there is another depth of 995 fathoms. The island, like most of the others in its vicinity, is almost entirely unknown, but we record here only those species which are now known from Mysol with considerable probability of accuracy. Many of these records are based upon specimens which are mentioned by Boulenger in his 
Catalogue as coming from Mysol; others are records taken from the collections reported upon by Peters and Doria, and others.

No turtles nor crocodiles appear among the definite records up to the present time. Boulenger has recorded ${ }^{1}$ Gekko monarchus (Dum. \& Bibr.) on the basis of a male and female in the British Museum. G. vittatus Houttuyn appears, as might be expected. *Draco lineatus Daudin occurs, as well as *Calotes cristatellus Kuhl.

Few scincs are recorded. They are Tiliqua gigas (Schn.), Dasia smaragdinum (Lesson), Leiolepisma fuscum (Dum. \& Bibr.), and Emoia cyanurum (Lesson). Many more surely remain to be found.

Of snakes we know only very few. Typhlops olivaceus (Gray) is said to occur, but this is almost certainly an error, for the species occurs elsewhere only in the Philippines and Borneo. Python amethystinus (Schn.), Enygrus carinatus (Schn.), and E. asper (Gthr.) are recorded. The last here reaches the western limit of its range. Stegonotus modestus (Schlegel), *Dendrophis pictus (Gmelin), Boiga irregularis (Bech.), ${ }^{*}$ Chrysopelea rhodopleuron Boie, and Pseudelaps muelleri (Schl.) close the list of reptiles.

There are three species of amphibians. Hyla amboinensis Horst is found only upon this island and Ambon, which is the type locality. The wide-ranging $H$. dolichopsis (Cope) occurs, while $H$, aruensis Horst was originally described from both the Aru Islands and Mysol. It possibly occurs in Papua also.

Now, it will be seen by looking at these notes that we have to deal with certain species reaching this island from the west which are on Ceram but not on Halmahera, though other species are of course also found on that island as well. However, the series of species as a whole shows a much closer relationship to that of Ceram, an island separated by deep water, than it does to that of Halmahera, an island connected by strings of islets which are separated from each other by only shallow straits. It would seem at first that this condition might be accounted for either upon the ground that we did not know Halmahera sufficiently well, or that these species have reached Mysol by accidental carriage. But, first, I can not believe that, if the forms existed on Halmahera, now so well known, they would not have been found long ere this, and secondly, if we had to account for the occurrence of only one or two species on Mysol, we might expect accidental carriage to be responsible, but this is not likely to be the case where we have a considerable number of species to account for upon an island which,

${ }^{1}$ Species marked with an asterisk reach here the extreme eastern limit of their range (five out of eighteen or nearly twenty per cent). 
like Mysol, is one of the least known and least visited of the islands in its vicinity. Mysol is important neither to the Malayan traders nor to the whites, from a commercial point of view. There are no large settlements on the island, and it is not as frequently visited as are some points on the mainland of New Guinea. Nevertheless, the more or less haphazard distribution of the three species of Hyla would favor the view that accidental introduction may have played a part here. Furthermore it is entirely possible that in the list of reptiles have been included one or more records which should be eliminated. At any rate, the fact remains that, so far as we now know, Mysol shares with Timor-Laut a position on the Malayan zoölogical frontier, though it remains much more of an enigma as regards the derivation of its fauna than does the other group of islands.

\section{Halmahera Group.}

None of the other Moluccan Islands is so well known herpetologically as are these; and a most complete résumé of their reptilian fauna has been written by Boettger (Abh. Senck. nat. ges. 1900-3, 25, p. 325-375, pl. 14-16). The islands of the group, consisting of the large island of Halmahera, with the small islands of Ternate and Batjan lying near by, are the ones where Kükenthal made the collections on which Boettger's paper is based. Other islands of the group less known are Tidor and Morotai. Farther to the south, and quite unknown herpetologically, lies the island of Obi. All of the Halmahera group, with the exception of Obi, are close together, separated from one another by only shallow water, though between Halmahera and Obi there is deep water, from 808 to over 1,000 fathoms. Between the group as a whole and New Guinea there is the not unusual condition of a string of small islands with deep water between and about them. Obi was once doubtless connected to the old bridge between Halmahera and New Guinea. The island does not seem ever to have been joined to any other land except this bridge, which is now gone, leaving only many small islands to show where it once existed. As a matter of fact, soundings are so few in this region that it is hard to see what is connected by submarine banks, and what is separated by chasm-like straits. However, a long series of islands, as if a continuation of the southern peninsula of Halmahera, stretches out towards Mysol and Salawati. None of these seem to be separated by water more than 60 fathoms deep. To the northward, again, lies the Papuan island of Gebe, directly between the southeastern peninsula of Halmahera and the Papuan island of Waigiu. The water between these islands seems to be much deeper, though there are no soundings available in a direct line between 
them. We should expect, then, from the conditions here, that this group of islands would show a much stronger preponderance of Papuan forms than the Ambon group, and as a matter of fact this is the case. To sum up, we conclude that Halmahera was joined to both Celebes and Papua; while Obi had an erstwhile indirect connection with both by being part of the old Halmahera-Papua commissure.

Twenty-five lizards are recorded, six of which are peculiar to the island. One of these is a species of Gehyra, a genus of usually wide-ranging species; while the others are all species of Lygosoma, using the generic term in its broadest sense. They are closely related to other Papuan species, and in many cases have been considered identical until a very short time ago. It is strange to see these Papuan species replaced in Halmahera by distinct forms, whereas in the Ambon group, so far as I can discern, individuals occur which are indistinguishable from Papuan examples, even though the island seems less closely related geographically to the Papuan region than does Halmahera.

Of all the species of lizards, only two can be said to be preeminently Malayan; these are Calotes cristatellus (Kuhl) and Mabuya multifasciata (Kuhl). The fact that there are fourteen Lygosomas shows how preponderating is the Papuan element among the lizards.

Of snakes there are seventeen, not counting the sea-species; and of these, six are peculiar to the island, two of them belonging to genera Styporhynchus and Calamorhabdium, not occurring elsewhere. The Malayan Python reticulatus (Schn.) occurs here, along with P. amethystinus (Schn.), which does not go west of Timor. The distribution of Cylindrophis rufus (Laur.), Ptyas dipsas (Schlegel), Typhlops ater Schl., and Testudo forstenii (Schl. \& Müll.), if it exists on the island, which I now doubt very much, shows that there was once direct connection between Celebes and Halmahera, perhaps through the Sula Islands, or perhaps by an independent bridge to the north of that group. A connection with Celebes through Obi is very improbable on hydrographic grounds. The Ambon group and especially Buru seem far more intimately related to the Sula Islands than these are to the islands about Halmahera.

Two species of Natrix and a Dendrophis, all confined to the island, are, of course, of Malay origin, although evidently modified by long isolation here. The other snakes are Papuan.

I have spoken already of the single land-tortoise, Testudo forstenii Schl. \& Müll., a rare species, reported from Celebes and Halmahera though it is probably absent from the latter; while only a single fresh-water tortoise occurs, 
the wide-ranging Cyclemys amboinensis (Daud.). Crocodilus porosus Schn. is also known.

Of the amphibians, eight in number, we find that four are peculiar, two representing genera not known elsewhere, Phrynixalus and Oreophryne. Broadly speaking, these show affinities much more Papuan than Malayan, as do also the other amphibians, except the two species of Rana. One of these is Rana moluccana Bttgr., closely related to Rana varians Boulenger, which is a species originally described from the island of Palawan in the southern Philippines, but since discovered on Celebes; so that here again the direct connection with Celebes is emphasized. The other frog, which is recorded as Rana macrodon Dum. \& Bibr., more probably represents $R$. modesta Blgr., which replaces the former species upon Celebes and Talaut, and has been reported by van Kampen from the island of Nusalaut near Ambon.

To sum up, we see that this group of Moluccas shows conditions decidedly different from those which we have already indicated for Ceram and the islands about Ambon. In many cases these northern islands show a closer relationship to Papua than do the others; though, strangely enough, such characteristic Papuan genera as Acanthophis and Pseudelaps occur upon Ceram, but not upon Halmahera, to say nothing of the fact that upon Ceram also we find the avian genus Casuarius, which occurs along with Acanthophis in the Ke Islands. These discrepancies can not in this case be explained by probable ignorance of the conditions, for the island of Halmahera we now know well. The only explanation possible is either two independent connections with New Guinea, or else a separation at different times of these two islands from a common landmass stretching out towards Papua. The hydrography of the region leads one to believe most strongly, one might almost say surely, that there were two, possibly more, separate connections. Halmahera was connected with Salawati along the line of the many small islands now existing, and Obi joined to this same bridge; while Ceram and Ambon may well have received their Papuan types by means of a connection passing through the Ke Islands.

Ke IsLands.

The Ke (variously spelled Ké, Kay, Kei, Key, etc.), or Ewaf Islands are a small, heavily forested group lying directly south of Cape van den Bosch of the Kumawa district, Dutch New Guinea. They are distant from this point some seventy miles, and from the southeast point of Ceram some 160 miles. The group itself consists of the island of Nuhu Jut, which is fifty miles long and only 
a few miles wide; Nuhu Roa, some 20 miles long and ten miles wide; as well as a large number of islets of varying size, on one of which the town of Tual is situated, the main settlement of the group, the island being of the same name.

The islands are, one might say, almost connected with Ceram; for the few soundings are of depths of only about a hundred fathoms, while many islands lie in a direct line and form a chain with many submerged banks and reefs just awash between them. Between the Ke Islands and the Aru Islands, and between the Ke Islands and New Guinea, the depth of water seems to be much greater. There are a number of soundings off towards the Aru Islands reaching the depth of almost 2,000 fathoms; and towards the island of Adi, off the New Guinea coast, almost as great a depth has been found.

These conditions at once associate the islands rather with the Moluccas than with the true Papuan groups; although, as we find on studying the records for the fauna, the Papuan element seems predominant. Our hydrographic knowledge of the region is too limited to say surely that there are no submarine evidences of connection with either New Guinea or the Aru Islands. If such evidences do not exist, we have simply another added case which shows how dangerous it is to rely exclusively upon data of this sort for the reconstruction of past land connections. That this connecting area was one of comparatively recent date, geologically speaking, is evidently proved by the intimate faunal relationship which the Ke Islands have with true Papuasia. It has been customary in the past to speak of the Ke and Aru groups as both being purely Papuasian in their fauna. This is perfectly true of the Aru Islands, but the Ke Archipelago shows strongly the influence of its direct relationship with Ceram.

There has just appeared an exhaustive study of the herpetology of these two groups from the pen of Dr. Jean Roux (Abh. Senck. nat. ges., 1910, 33, p. 211-247, taf. 13-14). Dr. Roux's data are especially valuable inasmuch as he adds considerably to the list which we previously had of species from both these groups. The following notes are made up largely from his list.

The snakes are nine in number, three of which are species of Typhlops; one, T. kraalii Doria, is peculiar to the island, and another, T. multilineatus Schl., is found both at Tual and in Dutch New Guinea. The other species are Python amethystinus (Schn.), Stegonotus modestus (Schl.), S. cucullatus (Dum. \& Bibr.), Dendrophis calligaster Gthr., Boiga irregularis (Bechst.), and Acanthophis antarcticus (Shaw). These, as may be seen at a glance, are forms of Papuan origin; yet nearly all of them occur in the Moluccas as well. The distribution 
of Acanthophis antarcticus (Shaw) is important, as we know almost certainly that in the Moluccas it is confined to Ceram. It has long been known from the Ke Islands; and now Roux records it from Aru, as well; so that its migration route to Ceram is plainly seen. Were it not for such species as this one and the Stegonotus, we might be inclined to imagine, in view of the great depth of water about the islands, that the Papuan species had reached Ke fortuitously.

This explanation, however, could not of course apply to any such number of species when we take the lizards into consideration as well. Of these Roux records twenty-one species. Five are wide-ranging members of the Gekkonidae, and their presence is not significant. Gekko vittatus Hout. and Gekko monarchus (Dum. \& Bibr.) both occur; the former Malayan, and the latter of Papuan affinity. Then, of the Agamidae, Roux records for the first time Physignathus temporalis (Gthr.), a species hitherto known from Queensland and Papua only; while on page 247 he remarks that Werner has reported Draco lineatus Daud., and has described $D$. ochropterus Werner, both from this group. As a matter of fact, $D$. lineatus was first recorded a long time ago, so that it is not especially surprising to find another peculiar species present. And in view of what we know of the distribution of such species as Acanthophis antarcticus, and the avian genus Casuarius, it is hard to understand why in regard to the Draco records Roux wrote:-

"Mit diesem Fund würde in die herpetologische Fauna der Kei-Inseln ein Element hineintreten, welches für eine frühere Relation dieses Archipels mit den mehr westlich gelegenen Inseln (sei es nordwestlich oder südwestlich) sprechen würde.

"Eine weitere Bestätigung dieser Fundortsangabe wäre wünschenswert."

We have already remarked on the hydrographic evidence, so we need do no more than call attention to it again in this connection.

Other lizards are abundant. The wide-ranging Varanus indicus (Daud.) is found commonly, as well as the geographical race of Tiliqua gigas (Schn.) subsp. keiensis Oud. The other scines number eleven species; and, though Sphenomorphus kuhnei (Roux) and Leiolepisma beccarii (Peters. \& Dor.) are peculiar to the islands, still the great majority are of direct Papuan origin, and might be expected to occur. One species should be mentioned specially, and that is Lygosoma muelleri (Schl.). This species is rare, extremely retiring in its habits, and seems to be generally confined to the dense forest. It is certainly not one which could by any chance have been carried about by human agency. Roux records it from both Ke and Aru. It was previously known, he says, 
only from New Guinea and Ceram. As a matter of fact there is a record for Ternate, but it is quite unsubstantiated. This distribution is directly comparable to that of the Death-adder, and as such is most interesting.

So far, we know of only two amphibians from the Ke Islands:- Hyla dolichopsis (Cope), which we know to be easily carried about, and Cornufer corrugatus (Dum.), which does not seem so likely to have had a similar history. The absence of amphibians in this case, however, must not be taken as offering evidence against a land connection. Van Kampen has shown that the land connections were probably in many cases so narrow as to lack suitable places where amphibians might breed. Very probably the connections which existed here were of this nature, and so very transitory that amphibians could not pass across them. There is no special need to postulate that these Ke Island connections had any special relation to the migration to New Guinea of its amphibian fauna.

\section{Aru Islands.}

The Aru Islands differ considerably in physical features on the one hand from the Ke Islands, which lie near by, and on the other hand from the opposite coast of New Guinea. The group consists of what was probably recently a single large low-lying island, heavily forested, and with many swamps and estuarine water ways. Lying in general in a north and south direction, it is some hundred miles long by forty-five miles wide. The divisions at the present time are into low-lying islands, simply separated by swampy creeks; and the major divisions are five in number - Kola, Wokam, Kobror, Koba, and Terangan. To the westward lies the small island of Wammer, on which is the renowned trading settlement of Dobo. Numerous other islands to the eastward and southeastward are separated from the main land-masses by water only a few feet deep. The group lies on the edge of a submerged bank of enormous extent, which reaches out to the northeastward from Melville Island and the Coburg Peninsula of Australia away to the western portion of New Guinea. The major portion of the Arafura Sea is from 30 to 70 fathoms in depth; while in the region in which we are interested - that is, between the Aru Islands and the Timoraka district off New Guinea and Prince Frederick Henry's Island the depth of water runs from 16 to 25 or 28 fathoms. Between New Guinea and Timor-Laut the water is deep - 459, 592 and 650 fathoms being depths which are given on the most recent Dutch Admiralty charts; while the still greater depths previously mentioned occur between the Aru and Ke groups. We see at once, then, from this that these islands may be considered almost an integral 
part of Papua itself. It has been customary to mention together in the same category both the Ke and the Aru Islands, and to consider them both as purely Papuan groups. This, however, is not justifiable, for the differentiation between them is very strongly marked indeed.

In drawing up these notes on the Aru Islands, use has been made of the same paper by Roux which was referred to under the Ke Islands. We may note, however, that among the species which he records in this paper on page 212 "zum erstenmal für die Aru-Inseln nachgewiesenen Arten" appears Chondropython viridis (Schlegel), which, as a matter of fact, was described by Schlegel from specimens from the Aru Islands, so that this is really the type locality for the species.

Roux also fails to point out a very fundamental difference between the fauna of the Ke and Aru groups. This is largely, to be sure, one of degree, many Papuan species occurring in Aru which do not get to Ke, while the species in Ke are also Papuan and found in Aru. The important point is that many of the species reach beyond Ke into the Moluccas; so that the important break in the fauna occurs between Ke and Aru, and not between these two groups and the Moluccas, the connection between Papua and Aru evidently having continued for a very long time after the break just mentioned took place.

It is hardly necessary to discuss the fauna here in detail. It is practically that of New Guinea itself; , and even the differences are unimportant, in view of the fact that any of the species supposedly confined to Aru may possibly be found at any time in the little-known regions of New Guinea lying across the straits.

Curiously enough Typhlops seems to be absent, as also Stegonotus cucullatus (Dum. \& Bibr.), which occurs upon Ke and New Guinea. It has probably simply not yet been found here. Otherwise all the Papuan snakes occurring in Ke are found here, with Natrix doriae Blgr., and Glyphodon tristis Gthr. added; while Roux found also Myron richardsonii Gray, which was previously known only from northern Australia.

The lizards number twenty-eight, of which two are peculiar-Sphenomorphus aruanus (Roux) and S. rufus (Blgr.). Lialis burtonii Gray was one of Roux's most interesting discoveries, emphasizing the extremely close Papuan affinity; while on the other hand the occurrence of Gekko monarchus (Dum. \& Bibr.) is unique, in that the species is derived from the west. This Gekko is a rare species throughout its range, and one which would seem very unlikely to be carried so far accidentally; if such a fate is not wholly improbable, at least 
it is much less likely than for many other of its more common congeners, and yet these do not seem to have attained to anything like so wide a range. We find Gekko monarchus on Mysol, Ke, and Aru, and its distribution suggests at once that it is really a very ancient species indeed, though the form is not one which offers other evidence of its antiquity.

The amphibians are purely Papuan, and number eight. Microbatrachus pusillus Roux represents a genus and species peculiar to the group, but one which will probably in time be found on New Guinea. The only other local form is Sphenophryne mertoni Roux. Curiously enough Cornufer corrugatus has not yet been found, though it probably exists still undiscovered along with other species.

\section{New Guinea.}

The enormous island of New Guinea lies directly south of the equator, with its northwest projection at 131 degrees east of Greenwich, and its southwest end at 151 degrees; so that the island is something over 1,200 miles long, while it varies in width from a narrow neck of land, where the McClure Gulf cuts almost through to the Wandamman Bay - a distance of only about twelve miles - to the width of almost 400 miles at the points where the 139th and the 142nd parallels cross the island. As everyone knows, the interior of the island is still largely unexplored. Various expeditions have searched the Arfak mountains in the northwest, and are now at work upon the Charles Louis and the Snow Mountains in the southwestern portion; while in British New Guinea, southeast, and German New Guinea, northeast, various expeditions have brought back important collections from the different mountain ranges. It was doubted for many years whether the reports that snow mountains existed were true. Recently they have been found both by Dutch and by British expeditions, and their great height - over 17,000 feet - verified. Still the great central area of the land, lying along the Dutch boundary, is entirely unknown.

A word regarding the political divisions of the island, as they will be spoken of often. All land west of the 141st parallel is Dutch. The remainder, to the eastward, is divided between Germany and England, the British possessing the Torres Strait region, a zone rather larger than that held by the Germans on the Pacific coast.

The fauna is distinctive in all groups of animals. It is not purely Australian, as formerly was supposed. To be sure, a number of species occur in common with Australia, and a still larger number of genera; but the range in Australia 
of the great majority of these is limited to the Cape York Peninsula region of Queensland, which undoubtedly within a short time formed an integral part of Papua itself, and may indeed be considered more Papuan than Australian. The rest of Australia - that part of the continent where were evolved the great hordes of typical Australian forms - was probably separated from northern Queensland until just-before the break took place through Torres Strait. The fauna of the Bismarck Archipelago, of the Louisiade Islands, and of the Solomons is truly Papuan, and shows little affinity to that of Australia, except inasmuch as some of these same Papuan forms occur which are now found to be common to both New Guinea and Queensland. As would be expected, these species are more common in that part of New Guinea which lies directly opposite Cape York Peninsula than they are in the western, Dutch section; though many of them are wide-ranging, and some reach out to those islands in the Moluccas where the Papuan element in the fauna is distinctly traceable.

No single true Malayan species is found in this whole region, except Dibamus novae-guineae, which may not be Malayan at all. A number of Malayan genera, however, occur, some of these reaching to Queensland itself.

Regarding New Guinea, again, it is only fair to say that we are hampered by lack of knowledge; and nearly every year new genera, especially among the inconspicuous burrowing forms, are being discovered; so that sets of figures showing proportionate relationships between the different elements in the fauna here may vary greatly from year to year.

Among the Amphibia conditions are of especial interest. The family of Cystignathidae, which is so characteristic of both Australia and South America, and serves to emphasize the relationship between these two areas, has only recently been found upon Papuan soil; while the enormous predominance of engystomatids observed by van Kampen has served him as the basis of a very ingenious theory regarding the coming of amphibians to New Guinea from the mainland of Asia. Now, we know, from recent data, that the life histories of many of these engystomatid amphibians are similar to those which have long been known for certain New World species, such as the classic Eleutherodactylus martinicensis (Ptrs.); that is, they skip their larval stage, and the life cycle is completed within the egg, which is placed for incubation either in soft mud, damp ground, or in the little collections of moisture which are held in the axils of leaves of so many tropical plants, bromeliaceous, and others. This is distinctly and at once evidently an adaptation to regions where only small amounts of standing water are usually met with. Van Kampen maintains that the 
connections which New Guinea previously had through the Moluccas with the Malayan islands were narrow necks of land where standing water was probably almost non-existent, and that for this reason the engystomatids which had taken up this method of development were the most fitted to pass over these commissures to what is now New Guinea itself. Members of the family occur throughout the whole area, but only sparingly until the Papuan region is reached, where they immediately become the most prominent feature of the amphibian fauna, and attain to an enormous diversity.

Van Kampen's views have been well expressed twice: once in a paper on, the amphibian fauna of New Guinea (Nova Guinea - Resultats de l'expedition scientifique Neerlandaise a la Nouvelle Guinee. Zool. 1909, 9, p. 31-49, pl. 2); and again in a most enlightening lecture which he delivered before the Royal natural history society of Batavia, entitled "De zoogeografie van den Indischen Archipel (Separate from Bijblad, Natuurkundig tijdschrift voor Ned.-Indië, 1909, 3, 4, p. 1-24, map). Of this I have published an English translation (Amer. nat., 1911, 45, p. 537-560).

The chelonians of New-Guinea, while not abundant in number of species, nevertheless show a strong differentiation, which is hardly paralleled by any other group of animals found upon the island and not by chelonians elsewhere in the world. In the first place, we find a relative of the American Chelydra, a peculiar species, which Douglas Ogilby named Devisia mythodes. This rare and strange form was discovered in British New Guinea, and the type is now in the Sydney museum. Its affinities are, broadly speaking, American, and so far as we know at present that is about all that can be said of it. Its habits are unknown and it remains probably the most remarkable known example of discontinuous distribution.

Four other genera of turtles are recorded; of which one, Caretochelys insculpta Ramsay, is not only peculiar to the island, but represents a genus similar in structure to the pelagic turtles; it is confined to the Fly River of British New Guinea. This species again is known by but few specimens, and its habits are as yet largely unknown. The occurrence of Pelochelys cantoris Gray is of peculiar interest, inasmuch as, while the creature is common upon the mainland of southeastern Asia, in the Philippines, and on Borneo and Sumatra, it has only recently been recorded from British Papua and has not been found upon the intervening islands. The other two genera represented are Chelodina, with two species, - one, C. novae-guineae Blgr., which is found upon the island of Timor and in British Papua; the other, C. siebenrocki Werner, which is con- 
fined, so far as we know, to New Guinea; the other genus is Emydura, two of the five species of which occur in New Guinea and Australia, while three other forms are strictly Papuan. Crocodilus porosus Schn. occurs widely spread over the whole island.

Among these ten species of chelonians, then, six are peculiar to the island, two generically autogenous; while of the other four, only one ranges into Malayan waters, and this same one is the only one that is not generically distinct from those genera known to the Malayan regions. The affinities of the various forms do not seem particularly Australian, inasmuch as Emydura is represented in Australia by only two species, one of which is reported only from Queensland; while on New Guinea we find five. There seems for this reason to be no object in not calling this genus truly Papuan in contradistinction to those genera which have obviously had their centre of dispersal in Australia, or perhaps even in Queensland.

It may be best in considering the lizards simply to run through the genera one by one, and note the relationships of each.

Gymnodactylus has three species which are also found upon other islands in the group, while four species are peculiar to Papua. The genus itself may perhaps be considered a Malayan one. Markedly strange is the occurrence of Thecadactylus australis, a species described by Günther; the only other species, which occurs in the West Indies, being T. rapicaudus (Houttuyn). The first mentioned species, discovered on one of the islands of Torres Straits, may be, but is probably not, an example of convergence; since with Devisia occurring here also, as well as cystignathoids which have a very South American look, it is hardly fair to propose this as a probable explanation for the occurrence.

Of Hemidactylus, there are two species, probable of Malayan origin, both occurring elsewhere.

Peropus may well be considered as probably having a purely Papuan origin; the genus contains two species which are restricted to Papua, and three which are found elsewhere as well.

A single wide-ranging Lepidodactylus is reported.

Of Gekko, a Malayan genus, one autocthonous species is found, likewise another species which ranges through the Moluceas and towards the Solomons, without occurring on any of the Sunda Islands. Liasis, on the other hand, may be considered Australian; of this genus one Australian species occurs, and another which is found only on New Guinea.

Amongst the Agamidae we have only Gonyocephalus, with four species, 
confined to the island and four which are not. This last genus presents a curious example of discontinuous dispersal. The species from the Greater Sunda Islands do not seem to be even subgenerically differentiated from the Papuan species; while two, known from the Andamans and Nicobars, are closely similar to the Papuan forms. While species occur in the Philippines, none have as yet been reported from the Sunda Islands east of Bali, nor in any of the Moluccas. The distribution, then, is a peculiar one for a lizard in this area. The species are conspicuous and have probably already been found on most of the islands where they occur.

Varanus is present, with three autocthonous species, two others which are wide-ranging, and one form which is confined to Papua and the Aru Islands. The genus is certainly one which has been directly derived from the westward. Tiliqua gigas (Schn.) is the single species of this Australian genus which ranges from its origin.

Using the generic term Lygosoma as a convenient general name to cover the many closely related small scines which have been considered elsewhere as being generically separable, but which have all been placed in this genus by Boulenger, we find the condition of affairs most astonishing in comparison with that on the Malayan islands - for here we have thirty-one peculiar species and in addition twenty others which range off the island. The almost omnipresent Cryptoblepharus boutonii (Desj.) is, of course, found too.

Tribolonotus is another peculiar monotypic genus with a single species, T. novae-guineae (Schl.), which is not known outside the island; while Dibamus .novae-guineae, though certainly more abundant in Papuasia than elsewhere, has recently been found in the Malay Peninsula and in Sumatra. It either occurs elsewhere undiscovered, or else the individuals from these two parts of the range represent different species, however indistinguishable they may seem to be.

The snakes show a somewhat different state of affairs from that of the lizards. The Australian character is very strongly brought out, and the purely Malayan forms do not seem to flourish in the area, inasmuch as they are represented by comparatively few genera, hardly any one of which has more than a single species within the range.

Typhlops may certainly be considered as having relations westward. Two species of the genus are autocthonous; one occurs in British New Guinea and in Queensland; another in Dutch New Guinea and the Ke Islands; while T. braminus (Daud.) is well known for its enormous range.

Liasis, an apparently Papuan genus, is represented by three species in New 
Guinea, one found in British New Guinea and Timor, and also in Queensland. The only other member of the genus has been found on the islands of Timor, Savu, and Samao.

Enygrus is another genus which originated here, and we find two species on the island.

Acrochordus, Chersydrus, and Fordonia are three monotypic genera, all of the same class, which range widely, probably owing to their semi-aquatic habits, as they are frequently found in estuarine regions where the water is strongly saline.

Three forms of Natrix occur, - one peculiar, another found also in Australia, and the third occurring on the Papuan islands of Waigiu and the Aru group. The genus so prominent on the Sunda Islands here reaches almost the limit of its range.

The monotypic Brachyorrhus albus (Linné) occurs in New Guinea, in the Moluccas, and on Timor.

Stegonotus, also Papuan, has two local species, and two others which occur on the Moluceas as well.

Dendrelaphis, a Malayan genus, has two peculiar species here; while Enhydris, a similar genus, has one autogenous form.

Dendrophis, also Malayan, has two peculiar species; one form ranges through the Moluccas, as well as through the Solomons, Bismarck Islands, and Queensland, and a fourth form is confined to New Guinea and the Bismarck Archipelago near by.

Boiga irregularis (Bechs.) is the single representative of the genus in this area, but the species has a wide range from Celebes eastward.

The other genera found, nine in number, are all of elapine affinities, and are probably closely associated with the similar forms which predominate so very strongly in Australia. Some of these genera, such as Pseudelaps, with one species; Apisthocalamus, with two species; Toxicocalamus, with one species; Pseudapisthocalamus, with one species, are peculiar to New Guinea. Micropechis has one species each in New Guinea and the Solomon Islands. Glyphodon and Acanthophis are two monotypic genera which occur both in Australia and in Papua. It should be noted, however, that G. tristis Gthr. occurs only in southeastern New Guinea.

Of the important and very characteristic Australian genus, Pseudechis, one species occurs in southeastern New Guinea and in Queensland, while another is confined to the same region in Papua. 
It will be seen from what has been written that the snakes are, as one might expect, decidedly more characteristic of the area in which they occur than are the lizards. In the first place, among the lizards the number of genera which are wide-ranging are far larger; and in the second place, few of these genera can be picked out as being distinctly of Australian affinity as compared to those found on other islands to the westward. Thus, excluding Thecadactylus, which has no affinities hereabouts at all, we have five genera of lizards which we may consider as being essentially Papuan and with no marked affinities either Malayan or Australian; while six genera may be considered as essentially Malayan. On the other hand, two only among the lizards show predominant Australian relationships.

Among the snakes, however, while there are eight genera which may be considered Malayan, still four of these are of almost certainly widespread accidental dispersal; while the remaining four form but a comparatively inconspicuous part of the whole ophidian fauna. Of the eight wholly Papuan genera, four are obviously of direct Australian derivation, while the others are strongly differentiated from relations on either side. There remain, besides, four genera, not wholly confined to the island, which are conspicuous Australian entities in the Papuan fauna, only one of them reaching as far as the island of Ceram in the Moluccas; while still another genus of southern affinity, Micropechis, occurs in New Guinea and on the Solomon Islands.

The snakes are almost as strongly what we would call Australian as are those of that country itself, although many of the Papuan species occur only in Queensland, that part of Australia which was most recently associated with it, and which we have elsewhere spoken of as forming, zoölogically speaking, almost an integral part of New Guinea itself.

Before leaving the reptiles, it is perhaps worth while to point out one record which may be doubted. It is a remarkable coincidence that Gymnodactylus marmoratus (Dum. \& Bibr.) should occur in just that part of New Guinea alone to which Javanese coolies have been brought for plantation work; so that we may consider that this Javanese species has in all probability been introduced into New Guinea in almost exactly the same way that the Papuan Hyla dolichopsis (Cope) has come fortuitously to Java by human agency.

The amphibians have been so completely discussed by Dr. P. N. van Kampen in several of his recent papers that there seems no reason for giving more than the briefest outline of the conditions which we find among them. Dr. van Kampen has treated this part of the fauna with its remarkable zoögeographical 
relationships in mind, so that there remains little to be added to what he has already said. His first paper appeared in "Nova Guinea: Resultats de l'expedition scientifique Neerlandaise a la Nouvelle Guinee" (1906, p. 163-180, 1 pl.), and gave a list of all the amphibians from New Guinea known up to that time. In the following year he published his excellent "Amphibien des Indischen Archipels," with tables of distribution for each form (Max Weber's Zool. ergeb. einer reise in Niederland. Ost-Indien; 4, 2, 1907, p. 383-416, 1 taf.). These revised again our knowledge of the distribution of the various forms, so that they might be referred to with the greatest ease; and finally in 1909, again in Nova Guinea $(1909,9,1, \mathrm{p} .31-49,1 \mathrm{pl}$.), he has described the booty of several Dutch expeditions to southern New Guinea, including some remarkable new forms, among them a single cystignathoid (Phanerotis novae-guineae van Kampen) from Merauke, the only one known upon the island. The revised list increases the number of species recorded considerably; now, counting Hyla ouwensi Barbour (Bull. M. C. Z., 1908, 51, p. 325), and the new genus and species, Pomatops valvifera Barbour (Proc. Biol. soc. Wash., 1910, 23, p. 89-90, pl. 1), the number is finally raised to sixty-five species, of which, as van Kampen has shown, an astonishing proportion are confined to Papua.

It seems hardly worth while to note further the conditions amongst these amphibians, since van Kampen has explained them so clearly. Suffice it to say that Engystomatidae alone constitute nearly fifty per cent of the entire fauna; that eighty-five per cent of all the species are peculiar to the island; and that the species which do occur off the island are with few exceptions found only near by upon Australia, in the Bismarck Archipelago, on the Aru, Ke, and Timor-Laut groups, etc. Chaperina fusca Mocq. is said to occur also on Borneo, which may be possible if we consider the type a specially archaic one; while on the other hand, Rana novae-britanniae Wern. has been reported from Sumatra. This of course is improbable; and possibly emphasizes the fact that species frequently look so much alike that it is impossible for us to separate them, when in reality we know from the physical circumstances of their occurrence that they can not be the same. Such a distribution for a Rana is absolutely impossible; and it would be interesting to know the breeding habits, notes, and other details regarding the life histories of both species, so that if they are as identical in appearance as we are told, they might be separated nominally, as they should be. 


\section{Bismarck Archipelago.}

When, many years ago, the Rev. G. Brown began to send reptiles from the Duke of York Island (now called New Lauenburg) to the British museum, it became at once evident that a local fauna of the very highest interest was being made known. This small island - lying between islands that were formerly called New Britain and New Ireland, but have been renamed by Germany New Pommerania and New Mecklenburg - was the site of a mission, and for a long time the fauna of this region was known only from the specimens sent back from this mission station. Since that time, however, the region has been seized by Germany, in spite of the fact that she had no valid claims based upon discovery here or elsewhere in the Pacific; and since then collecting in the whole group now known as the Bismarck Archipelago has gone on quite extensively, with the exception that from the island of New Mecklenburg itself no records are forthcoming. In 1909 Franz Werner published an extensive paper upon the reptiles and batrachians of the Bismarck Archipelago (Mitt. Mus. nat. Berlin, 1900, 1, p. 1132,46 text figures). Referring to this, we find that there is a fauna here resembling closely that occurring upon Ne w Guinea, but lacking the Australian facies, which become so evident in the Torres Strait region of Papua itself. Thus we find six wide-ranging Gekkos, none of them of special importance; whilst among the agamids occur two Papuan species of Gonyocephalus, and a genus and species not known from anywhere else, namely, Diptychodera lobata Bttgr. Only a single Varanus, the wide-ranging $V$. indicus (Daudin), is recorded; while we find no less than eleven scincids, of what we have called in general terms Lygosoma. One of these, Emoia impar (Werner), is autogenous. Many of the other species are wide-ranging; but still others occur simply on the near by mainland of New Guinea; and one, Riopa albofasciolatum (Gthr.), reaches also to Queensland and the Solomons, occurring on New Guinea as well. This species, however, is a rather rare one; and a form of Riopa is not one which by its habits is likely to be subject to artificial transport through the agency of man.

The snakes, as one would expect, are even more differentiated than are the lizards. There are three species of Typhlops, none of which is found elsewhere. This is very remarkable, in that the surrounding regions are phenomenally poor in species of this genus. This may be due, however, to the fact that as yet they are incompletely explored. Python amethystinus (Schneider) occurs, as well as a peculiar genus, Nardoa boa (Schlegel). This group shares with the Solomon Islands Enygrus australis Montrouz., while the two other species 
common in this region also occur, E. carinatus (Schneider) and E. asper (Günther). Both species of Natrix, N. hypomelas (Günther) and N. dahli (Werner), are peculiar to the Bismarck group. One Stegonotus, S. heterurus Blgr., occurs here only, and along with it the more wide-ranging S. modestus (Schlegel). Two species of Dendrophis occur:- D. lineolatus Hombr. and Jacq. and D. calligaster Günther, both wide-ranging. The only other two land species are both well known throughout the whole area. They are Boiga irregularis (Bechs.) and the more strictly Papuan Pseudelaps muelleri (Schlegel).

Thus it will be seen that the reptiles, while obviously most closely related to those of New Guinea, show hardly any relationship with those of Australia, only one land proteroglyph occurring, so far as is known; while all the other genera are originally derived from the Asiatic mainland through New Guinea.

Only five amphibians occur. They are Rana novae-britanniae Werner, which has been mentioned before as supposedly having the impossible distribution of Sumatra and New Britain; Cornufer boulengeri Boettger, a peculiar species; the Papuan C.corrugatus (A. Dum.), a supposedly local variety of Hyla dolichopsis (Cope); and a so-called Hylella brachypus (Werner). I agree with van Kampen in considering the absence of vomerine teeth an insufficient distinction in itself to separate the two genera Hyla and Hylella; while the subspecies of Hyla dolichopsis (Cope) does not seem to be very satisfactory. I fail to find the characters which have been assigned as distinctive of the Ternatian subspecies tenuigranulata Boettger as actually serving to distinguish this from the variable individuals on the mainland of New Guinea; and I believe that the same condition obtains here regarding the subspecies pollicaris.

I have not mentioned Crocodilus porosus Schneider, because it is so wideranging as hardly to deserve constant repetition. It is important also to point out the fact that the remarkable development of amphibians in the Solomon Islands finds no parallel among these islands; another point of still greater import is the fact that the two genera, Enygrus and Stegonotus, have peculiar species differentiated in the Bismarck Archipelago, which have been derived of course from Papua; while the same genera occurring in the Moluccas have true Papuan species over most of the islands, except in the case of Stegonotus batjanensis (Günther), localized in the Halmahera group; while upon Ceram, for instance, two unmodified Papuan species occur. The fauna, of course, is a small one in point of number of genera, so that it is impossible to point out this condition of affairs in more than a few types. It would suggest strongly that the separation 
between New Guinea and these islands is an older one than that between New Guinea and the Moluccas.

\section{Solomon IsLands.}

The Solomon Islands consist of a long chain of high mountainous islands, many of them of considerable size, stretching away to the southeast from the Bismarck group, and lying parallel to the coast-line of southeastern New Guinea. There is really good reason for recognising the Solomon Islands as being of sufficient zoölogic differentiation to warrant their separate consideration from the Bismarck group. To be sure, the islands are of much the same character and size; none of them being quite as large, however, as either New Pomerania or New Mecklenburg. Generally speaking they are now fairly well known, thanks especially to the researches of Guppy some years ago. His collections were reported upon by Boulenger.(Trans. Zool. soc. London, 1886, 12, p. 35-62, pl. 7-13).

From some points of view the difference between these two faunae are insignificant. It is most unfortunate that we have so few hydrographic data on this area. Soundings are few and far between upon all sides of the group, and they do not show anything of the submarine relationship between these two groups of islands and the Papuan mainland. It seems very likely from the conditions of the fauna that the Solomon Islands, or some of them at least, remained connected and formed a single land-mass for a very considerable time after their separation from the region of the Bismarck Archipelago took place. This is suggested by the fact, as will appear later, that a number of most characteristic autogenous forms occur upon many of the islands, while they do not occur in the Bismarck group. On the other hand, it is worth noting, as Boulenger has already said (Proc. Zool. soc. London, 1888, p. 89), that between the extreme islands, Faro to the northwest, and San Cristoval towards the southeast, there is considerable difference in the abundance and variety of amphibian life; Faro being strongly Papuasian, and the other end of the group far less so. This immediately suggests that the islands separated from one another progressively from the lower end of the chain; or, in other words, that the subsidence, if this be considered the cause of their separation, began with the depression of the area to the southeast of the group, and continued in a more or less northwest direction. This seems reasonable, inasmuch as New Caledonia, though obviously a continental island, with a fauna derived over a previous land connection, lacks snakes and amphibians; while the Fijis, lying nearer to the source of supply, 
so to speak, support the peculiar ophidian Ogmodon vitianus Peters and several species of the amphibian genus Cornufer, which are, of course, not found elsewhere.

The Solomon Islands concerning which we have data are San Cristoval, Ugi, Guadalcanar, Treasury Island, Faro Island, and Howla, in the Shortland group; and Florida Island, or Gela. Thus it will be seen that for some of the islands not a single record is fortheoming. Boulenger (Proc. Zool. soc. London, 1888, p. 90) prepared a table of distribution giving the ranges within the group of all the species which were known up to 1888; and added again to our knowledge of this fauna by another paper (Proc. Zool. soc. London, 1890, p. 30-31, pI. 2), which reported upon C. M. Woodford's second collection from Gela; Woodford being the person to whom, next to Guppy, we owe our most considerable zoölogical knowledge of the group.

But few of the species found here are confined to a single island; and the exception occurs in the ophidian genus Denisonia, each of the three known species of which occurs on a single island. The genus evidently evolved by isolation, when most of the Solomons were connected in one land mass, from some Pseudclaps- or Pseudechis-like ancestor, perhaps Pseudelaps itself; and then the species each became differentiated from among the individuals isolated on each sland when the group took on its present aspect. It is hardly worth while to discuss the reptiles at greater length. Suffice it to say that Gekkos occur as in the Bismarcks, with the exception of two peculiar species of Lepidodactylus, both confined to Faro Island, so far as is now known; but it must be remembered that this island is better known herpetologically than almost any other, and undoubtedly many species which appear to have a limited or discontinuous distribution within the group are in reality of general dispersal, did we but know. The same Gonyocephalus, Varanus, and Crocodilus occur also as in the Bismarcks; while besides the usual wide-ranging scincids, four peculiar species occur, some found on a single island, others occurring on several. Corucia zebrata Gray is an autogenous genus found probably throughout the group.

Among the snakes a single peculiar Typhlops, T. aluensis Blgr., is noteworthy, as apparently occurring only on Alu in the Shortland group; while the species of Enygrus, Dendrophis, and Boiga occur widely spread. The species of Denisonia have been mentioned.

It is amongst the amphibians that we find a truly remarkable state of affairs:- four astonishing Ranas, no one of the species confined to a single island, all peculiar to the group; concerning the development of one species, 
R. opisthodon Blgr., Boulenger (Trans. Zool. soc. London, 1888, 12, p. 51) quotes the following from Guppy's field notes:-

"During a descent from one of the peaks of Faro Island I stopped at a stream some 400 feet above the sea, where my native boys collected from the moist crevices of the rocks close to the water a number of transparent gelatinous balls, rather smaller than a marble. Each of these balls contained a young frog, about 4 lines in length, apparently fully developed, with very long hind legs and short fore legs, no tail, and bearing on the sides of the body small tufts of what seemed to be branchiae. On my rupturing the ball or egg in which the little animal was doubled up, the tiny frog took a marvellous leap into its existence, and disappeared before I could catch it."

In addition to the above Boulenger observes:-

"In illustration of this interesting observation, Mr. Guppy sent several ova and recently hatched young, which are to be referred without the slightest doubt to Rana opisthodon. The ovum, which measures from 6 to 10 millim. in diameter, is a transparent spherical capsule in which the young frog is coiled up in the same way as figured by Peters ${ }^{-1}$ in Hylodes martinicensis; but none of the specimens, which are in an advanced stage of development, show anything of a tail. There are no gills, but on the side of the abdomen are several regular transverse folds (which in their arrangement remind of the gill-openings of Plagiostomous Fishes), the function of which perhaps is that of breathingorgans, like the tail of Hylodes. The tip of the snout is furnished with a small conical protuberance, projecting slightly through the delicate envelope of the egg, and evidently used to perforate that envelope, as is shown by one of the specimens."

The characteristic genus Cornufer is represented by four species, two of which are autocthonous; and in one species of these, $C$. solomonis Blgr., the describer indicates that a probable intra-oval metamorphosis also takes place, owing to the condition of the ova in the ducts. It is of great importance to emphasize the fact that here, as in New Guinea, we have so prominent this adaptation to life in a region where standing water in the shape of ponds or lakes is rare. From the steep configuration of the islands, it becomes evident that fresh-water must almost always occur in the form of swift-running streams. It is well to recall again van Kampen's suggestion that the assumption of this mode of reproduction has played a very important part in permitting amphibians to extend here to the present frontier of their range. 
- But we have not yet mentioned really the half of the peculiarities of this amphibian fauna; for amongst the Ranidae we find a remarkable autogenous genus, so far known only from Faro Island,--Batrachylodes vertebralis Blgr.; and upon all of the islands, with the exception of San Cristoval, we find a ranidderivative so differentiated as to constitute the type of a peculiar family, the single known species being Ceratrobatrachus guentheri Blgr: It is interesting to note that hitherto every island explored, with the exception of the one mentioned, which was probably separated very early from the rest of the group, supports this peculiar creature; but it is still more remarkable that from the different islands as we know them now there does not seem to be any peculiar local differentiation amongst the various individuals. This may perhaps be due to the fact that the form itself seems to be an especially variable one.

Three peculiar species of Hyla close the list. 


\section{ANNOTATED LIST OF SPECIES.}

\section{AMPHIBIA.}

\section{Ichthyophis monochrous (BLEEKER).}

Bleeker, Nat. tijd. Ned. Ind., 1858, 16, p. 188. Boulenger, Fauna Brit. India. Rept. Batr., 1890, p. 517.

Type locality: - Sinkawang, west coast of Borneo.

Only a single example of this species was met with, an adult from Rungeet Valley, border of British and Independent Sikkim.

This coecilian is known from India, the Malay Peninsula, Sumatra, Borneo, and Java.

Oxyglossus lima Tschudr.

Tschudr, Class. Batr., 1838, p. 85. Boulenger, Cat. Batr. Sal. Brit. mus., 1882, p. 5-6.

Type locality: - Java.

A very common frog in the swift running waters about Buitenzorg. Ten. specimens were taken. Bryant also has sent in two from Buitenzorg, and one from Tambun in Bantam.

Known from southeastern Asia and Java.

Rana macrodon DUMeril et Bibron.

Domeril ex Bibron, Erpet. gen., 1841, 8, p. 382. Boulenger, Cat. Batr. Sal. Brit. mus., 1882, p. 24-25.

Type locality:- Dumeril and Bibron had six specimens in the Paris museum,- five from Java, whence undoubtedly the very first specimens came (coll. of Kuhl). The sixth specimen was supposed to have been taken in Celebes by Quoy and Gaimard. This undoubtedly represented what is now known as Rana modesta Boulenger.

This form has a wide range on the mainland of Asia, and is also known from Sumatra, and the near by groups, Natuna, Borneo, Java, Lombok, and Flores.

\section{Rana tigerina DAUDIN.}

Datdin, Hist. nat. rain., 1803, fol. ed., p. 42; quarto ed. (p. 64), pl. 20 (not seen). Stejnegrr, Bull. 58, U. S. nat. mus., 1907, p. 139-142.

Type locality: - Bengal.

Careful comparison of adults from various stations in the wide range of 
this species will almost certainly show that it has developed a number of local races. Already van Kampen (Zool. ergeb. Max Weber's reise, 1907, 4, 2, p. 388) has noted that specimens from Celebes vary from others. These he calls $R$. $t$. angustopalmata. His sketches of a foot of a specimen each from Calcutta, Buitenzorg, and Tempe, Celebes, show well his reason for this designation.

Stejneger (loc. cit., p. 142) writes "Specimens from Borneo, which I had the privilege of examining in British Museum, have the vomerine groups of teeth more oblique and separated from the choanæ by a space fully equal to that between the two patches. I can not, therefore, agree in regarding Rana schlueteri Werner as a synonym."

I think this form may best be known as $R$. $t$. schlueteri Werner.

Unfortunately the adults of this species are everywhere very shy and difficult to capture. Besides two from Sarawak, I have full-grown examples from Buitenzorg, Java, only. This frog was, however, taken at the following localities:- Lucknow, 3 half grown; Sunderbans, Lower Bengal, 4 young; Teesta Valley, Bhutan frontier, 8 small; Mandalay, Burma, 1 half grown; Tigyaing, Upper Burma, 1 almost adult; Buitenzorg, Java, large series of all ages; Bali, Lesser Sunda Islands, 3 young; Lombok, Lesser Sunda Islands, 4 young and tadpoles; Makassar, Celebes, 10 young, half grown and almost adult. These represent $R$. $t$. angustopalmata van Kampen. The describer of this form had specimens from Makassar and other stations as well as Tempe, whence came the example figured. This record from Buleleng, Bali Island, is a substantiation of the previous notice of this form here, by Bleeker. Van Kampen (loc. cit.) in his table of distribution has wisely questioned Bleeker's record until it might be confirmed. Dr. van Kampen was with me, and we both took examples of this frog from the same rice-field. Bryant's collection contained an enormous number from west Java.

This species occurs almost everywhere throughout southeastern Asia, and through the Malayan Islands to Timor and Rotti.

\section{Rana limnocharis WIEGMANN}

Wiegmann, Nova acta Acad. Lcop. Carol., 1835, 17, 1, p. 255. Sterneger, Bull. 58, U. S. nat. mus., 1907 , p. 127

Type locality:- not given, but from context it may be concluded that description was based on Boie's Javan material.

This frog may be recognized in the field from Rana tigerina, which it so closely resembles, by its less webbed feet, and by its lacking the fold of skin along the 
outer edge of fifth toe. This species has the same habits as Rana tigerina, with which it is usually found associated in the swamps, rice-fields, and banks of streams. It is, however, much less common. Bryant's collection contains but two specimens. These do not agree at all with specimens from Japan and the Riu Kui Islands. So that there is some doubt as to just what Rana limnocharis really is. The species is very rare in Java; consequently if the type came from Java, it is quite likely that it was a young Rana tigerina. In which case both $R$. limnocharis, so-called, from Java and Japan, will need new names.

Rana papua Lesson.

Plate 5, fig. 15.

Lesson, Voy. Coquille. Zool., 1830, 2, 1, p. 59, pl. 7, fig. 1. Boulenger, Cat. Batr. Sal. Brit. mus., 1882, p. 64. Van Kampen, Nova Guinea, 1906, 5, 6, p. 164.

Type locality: - the island of Waigiu. Here, Lesson remarks, the natives brought them almost every day to the ship as an article of food.

Six examples were taken in Sorong, one at Manokwari, and two at Pom, Jobi Island. A large female from the last-named station has been figured (Pl. 5, fig. 15) and the colors are accurate to the living condition. A male from Pom exhibits well-developed humeral glands. Boulenger (loc. cit.) remarks that they do not occur in this species, while van Kampen, on the other hand, found them on a male from Ibaïso. His records show that this was the only adult male which he had before him. Van Kampen thinks that this may be a chance occurrence. It seems, however, that possibly there may be some geographical variation. Boulenger's Papuan examples were all from the Torres Straits region, while these two cases are from the northeast region.

This frog is now known from Waigiu, Batanta, Jobi, the Aru Islands besides New Guinea itself. It is also reported from northern Australia and Timor-Laut.

\section{Rana moluccana BoetTGer.}

Plate 5, fig. 12.

Boettger, Zool. anz., 1895, 18, p. 132. Abh. Senck. nat. ges., 1900, 25, p. $366 . \quad$ (Rana varians BoulenGER).

Type locality:- "Auf ganz Halmaheira und Ternate häufig."

While Boettger in his preliminary report described this frog as peculiar to the Halmahera group of the Moluccas, he considered it as synonymous with Rana varians Boulenger in the final report on Kükenthal's collection. Thanks to Dr. Stejneger I have before me three topotypes of $R$. varians, U. S. nat. mus., Nos. 39,964, 39,977, 39,978, from Pancal and Puerto Princesa, Palawan. On comparing these with one from Gane, Halmahera, and eighteen from Ternate, it becomes at once evident that, though these species are related closely, yet they 
are not specifically identical. They may be separated by the smaller tympanum of $R$. varians, and by the less extent of web between the toes of $R$. moluccana, as well as other characters regarding the size and position of choanae and vomerine

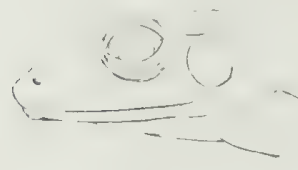

a

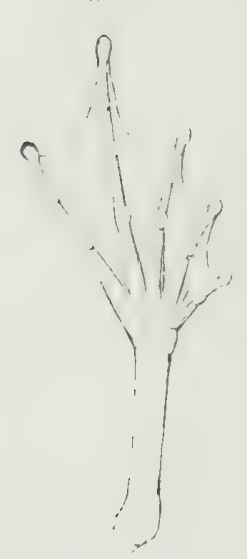

b

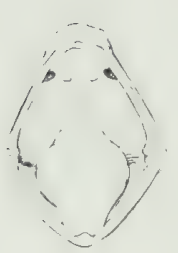

c

Rana varians Boulenger, Topotype.

a, profile of head; b, palmar view of foot; $c$, gape.

Rana moluccana Boettger, Topotype.

d, profile of head; e, palmar view of foot; $f$, gape. teeth groups. The difference between these characters is made clear in the figures.

The Gane specimen was taken in the deep woods without any fresh-water near by. In this individual the vomerine teeth are rather more separated, and are placed in a slightly more anterior position than is the case with any one of the Ternatian series. The interorbital space is slightly wider in the example from Halmahera than in the others. It is also much more brilliantly colored, the legs being heavily barred above, and very brilliant yellow below. This coloration may have relation to the nuptial season, or may be due to life in the woods. The lot from Ternate were all taken from a well, the water in which stood almost level with the surface, and from which the frogs could have easily escaped. They seemed to be living a strictly aquatic life. They were taken a month later than the Gane frog, in late February, instead of January. It is not safe to draw any conclusions from so unevenly distributed material; but this series points strongly to a frog upon Ternate which is not certainly identical with those on Halmahera, and is certainly not identical with Rana varians of Palawan. Nevertheless, the origin of these frogs is all the same, and the close relationship serves to emphasize the existence of a connection from the Phillippines through Celebes to the Halmahera group. It will be very instructive to learn whether a frog of this type occurs on the Sula Islands, Obi, or Buru. 
Rana erythraea SCHLEGeL.

Schleger, Abbild. Amphib., 1837, dec. 1, p. 27, pl. 9, fig. 3. Botlenger, Cat. Batr. Sal. Brit. mus., 1882 , p. 65-66.

Type locality:- Java and Sumatra.

This is a common species about Buitenzorg. It was taken much more frequently in swift water than in the rice-fields. About twenty examples were preserved. Bryant brought back eight from Buitenzorg, four from Depok, and one from Daru, Bantam.

It is known from Burma, Siam, the Malay Peninsula; and, among the islands, on Sumatra, Nias, Natuna, Borneo, Java, Celebes, and the Philippines. It has been reported from Banca by Bleeker ( $C f$. van Kampen, Zool. ergeb. Max Weber's Reise, 1907, 4, 2, p. 416).

Rana chalconota SCHLEgel.

Schlegel, Abbild.-Amphib., 1837, dec. 1, p. 23, pl. 9, fig. 1. Boulenger, Cat. Batr. Sal. Brit. mus., 1882 , p. 66.

Type locality:- Java, figured specimen taken by Kuhl; later known to Schlegel from Sumatra.

A single large specimen of this interesting species was taken at Tjibodas, Java. The hind limb being carried forward the tibiotarsal articulation reaches beyond the snout. In other respects the individual is typical. Bryant got many examples of all ages at Tjibodas and in the surrounding districts, and a few near Buitenzorg.

Reported from the Philippines, Sumatra, Nias, Borneo, Java, and Celebes.

Polypedates reinwardtii (W AGLER).

Wagler, Nat. syst. Amphib., 1830, p. 200. Boulenger, Cat. Batr. Sal. Brit. mus., 1882, p. 88-90.

Type locality:- Almost surely Java, though none is specified.

Of this most beautiful tree-frog, five were found in Buitenzorg, and two in Tjibodas. Bryant got thirteen at Buitenzorg. Schlegel's figure gives a good idea of the splendid colors of what was probably also a Javan example. (Schlegel, Abbild. Amphib., 1837, dec. 1, pl. 30, figs. 1, 2, 4). It makes a good pet, becomes quite tame, and is capable of the most astonishing leaps.

Known only from Java and Sumatra. Van Kampen (Zool. ergeb. Max Weber's Reise, 1907, 4, 2, p. 416) notes that Boulenger pays no attention to the fact that Peters reported the species from Borneo. The record certainly needs confirmation. 


\section{Polypedates leucomystax (Gravenhorst).}

Gravenhorst, Delic. Mus. zool. Vratislav., 1829, p. 26. Stejneger, Bull. 58, U. S. nat. mus., 1907, p. $157-159$.

Type locality:- Java.

Twenty-five specimens taken in Buitenzorg, where the species is very abundant, and one at Tjibodas, Java, show great variety in color and markings. Bryant's series of thirteen from Buitenzorg, and one from Gunung Bunder, Mt. Salak, vary similarly. I agree completely with the observations of Flower (Proc. Zool. soc. London, 1896, p. 906) as to the value of these markings for determining color varieties. The condition after killing and preserving is entirely dependent on the phase of color which had been assumed by the animal just before death. They change color and color-pattern with considerable rapidity. Flower in a subsequent paper (Proc. Zool. soc. London, 1899, p. 898-899) notes that they seem to breed at almost all times of the year. All of these Javanese individuals have the skin of the head more or less involved in the cranial ossification. This seems to begin when the frog is about $1 \frac{1}{4}{ }^{\prime \prime}$ long, and when the creature is $2^{\prime \prime}$ long the process is complete.

Five specimens from Mt. Wuchi, Hainan, though not fully adult seem to have a much less extensive ossification than Javan examples of the same size. This may be due to the fact that these specimens were originally preserved in formol, a preservative which usually should be carefully shunned, unless the collector is skilled in its use.

A wide-ranging form over southeastern Asia, the Philippines, Sumatra, Nias, Banka, Natuna, Borneo, Java, Madura, Timor, Sumba, Salayer, and Celebes. Reported once from Ternate, no doubt incorrectly.

Polypedates javanus (BoEtTGER).

Plate 8, fig. 31 .

BoEtTGer, Zool. anz, 1893, 16, p. 338.

Type locality:- Mt. Tjiserupan, west Java.

Bryant had a single fine example from Tjibodas, Mt. Gede, and also one from Buitenzorg.

The species is confined to Java.

\section{Philautus aurifasciatus (SCHLEGEL).}

Schlegel, Abbild. Amphib., 1837, dec. 1, p. 27, pl. 9, fig. 4, Boulenger, Cat. Batr. Sal. Brit. mus., 1882, p. 100. Van Kampen, Zool. ergeb. Max Weber's Reise, 1907, 4, 2, p. 404.

Type locality:- mountains of Java.

A single example each in Bryant's and my own collections from the moun- 
tain branch of the Buitenzorg Garden at Tjibodas. These specimens agree well with van Kampen's notes on one from the same locality. Both vary considerably from Boulenger's description, as he has shown.

Known from the Natunas, Borneo, and Java.

\section{Philautus pictus (Peters). ${ }^{1}$}

Peters, Mon. Berl. akad., 1871, p. 580. Boulenger, Cat. Batr. Sal. Brit. mus., 1882, p. 99.

Type locality:-Sarawak, Borneo.

A single example in poor preservation, but evidently belonging to this species, was taken near the town of Johore Bahru, Malay Peninsula.

Known now from several stations in the Peninsula as well as Borneo.

Philautus pallidipes (Barbour).

"Snout rounded, as long as diameter of orbit; canthus rostralis moderately distinct; loreal region slightly concave; nostril slightly nearer tip of snout than eye; interorbital space broader than upper eyelid; tympanum very small, round, rather indistinct, one-fifth diameter of eye. Fingers free, toes not quite half webbed; disks prominent, larger than tympanum; subarticular tubercles small, a small elongate inner metatarsal tubercle. The hind limb being carried forward along the body, the tibiotarsal articulation reaches beyond the tip of the snout. Skin minutely granular above; beneath both throat and belly more coarsely granular. Upper surfaces uniform brown, varying from dark reddish to grayish. Palms of hands and ends of toes yellow. Throat so heavily punctulate with dark brown as to appear almost of solid color, belly and inner sides of limbs less heavily specked on a yellow ground. Outer sides of thighs barred with very deep brown.

Type, No. 2442, Museum of Comparative Zoölogy, from near the summit of the volcano Pangerango, Java. T. Barbour, collector.

The small size (body 1 inch long for nearly adult female), lack of cranial ossification, and absence of vomerine teeth place this form with the genus Ixalus. The fact, however, that two species of Polypedates have been discovered, viz. $P$. edentulus (F. Müll), and $P$. anodon (Van Kampen), which also lack vomerine teeth, shows how scant is the basis of separation for the two genera. Cranial ossification is unknown in Ixalus, and, of course, is not general in Polypedates so that the adult size alone stands as the generic distinction. A very slim one surely." Proc. Biol. soc. Wash., 1908, 21, p. 190.

${ }^{1}$ Philautus takes the place of Ixalus, preoccupied. (Stejneger, Proc. U. S. nat. mus., 1905, 28, p. 346). 
Nyctixalus margaritifer BOULENGER.

Plate 8, fig. 32.

Boulenger, Ann. mag. nat. hist., 1882, ser. 5, 10, p. 35.

Type locality:- East Indies.

This species was described from a single example in the Brussels museum with no definite locality. It has since been taken three or four times in the mountains of west Java. Bryant got one specimen on the slopes of Mt. Gede, near Tjibodas, during August, 1909. This single individual agrees generally with the original description. It does differ, however, in having an apparently rather smaller tympanum, which is bordered above by a strong fold running from the eye to the axil. So that it is possible that this specimen, which is an adult female, may in reality represent a second species of this little-known genus; though without more material conjecture is futile. The type was a male, and there may easily be some sexual dimorphism.

\section{Cornufer corrugatus (A. DomeriL).}

A. Dumeril, Ann. sci. nat. 1853, ser. 3, 19, p. 176. Boulenger, Cat. Batr. Sal. Brit. mus., 1882, p.

110. Van Kampen, Nova Guinea, 1906, 5, 6, p. 167.

Type locality:- Java. Incorrect, it has not been taken in the true Malayan Islands.

A single young individual evidently of this species was taken under a rotten $\log$ in the woods near Ansus, Jobi Island, New Guinea. This specimen has no light dorsal line as van Kampen has noted for -some Papuan specimens, and Boettger (Abh. Senck. nat. ges., 1901, 25, 2, p. 367) for Halmahera. Five specimens have just been received from Goram Island, a new locality for the species.

Now known from the Philippines, Ceram, Halmahera, Batanta, New Guinea, Jobi, Misori Island, and the Bismarck and Solomon Islands.

Cornufer corrugatus rubristriatus BARBOUR.

Plate 5, fig. 14.

Barbour, Proc. Biol. soc. Wash., 1908, 21, p. 190.

Type locality:- Roon Island, Geelvink Bay, New Guinea.

Two examples from this island seemed almost specifically distinct from true C.corrugatus. They both lack the characteristic dermal fold which extends from the eye to the shoulder. The tympana are round instead of vertically oval, there are three palmar tubercles, and the tibiotarsal articulation reaches only to the eye. The inner sides of the thighs are yellow, and down the brownish olive back runs a brick-red vertebral stripe.

In other characters there does not occur any such divergence. It seems 
better to consider this a localized island race, and not a distinct species; though more specimens of various ages and from a number of localities might completely separate this race, or possibly invalidate it altogether.

Microhyla annectans Bodlenger.

Plate 7, fig. 26.

Boulenger, Ann. mag. nat. hist., 1900, ser. 7, 6, p. 188. Van Kampen, Zool. ergeb. Max Weber's Reise, 1907, 4, 2, p. 404-405.

Type locality:- Larut Hills, Perak.

Two examples from the Botanical Gardens at Tjibodas, about 4,500 feet in altitude. During March and April specimens of this genus were very rare, and it was only after long searching that these few individuals were found. They spring nimbly about on the damp leaf-mould of the deep forest, often clinging to a leaf as would a Hyla. Their colors serve as a most perfect protection against their being seen.

Now known from Java and the Malay Peninsula. It should be noted how this distribution is paralleled by that of many other species of both Reptilia and Amphibia.

Microhyla achatina (BOIE).

Plate 7, fig. 27.

Bore, Isis, 1827, p. 294. Boulenger, Cat. Batr. Sal. Brit. mus., 1882, p. 166.

Type locality:- Java.

A single specimen taken in April, 1907, on the volcano Papangdaiang, near Garut, Java. Altitude about 5,000 feet. This is a typical highland species in Java; I could not learn that it had ever been found near Buitenzorg. It is said to occur commonly at certain seasons near Sukabumi and Tjibodas, about 3,000 and 4,000 feet respectively. From the latter station Bryant has a very minute frog which I think belongs to this species.

Now known from the Malay Peninsula, Sumatra, Nias, and Java.

Kaloula pulchra GraY.

Plate 7, fig. 29.

GraT, Zool. misc., 1831, p. 38. Bodlenger, Cat. Batr. Sal. Brit. mus., 1882, p. 170-171.

Type locality:- China.

This species is not uncommon about Makassar, Celebes. It is strictly nocturnal, remaining hidden in holes during the daytime. These specimens do not agree at all with Gray's original description of color. He writes, "Back brown; black spotted; beneath pale; with a broad band across the forehead and the fore legs, and on each side from the eye to the groin rose red." The 
colored figure of a Makassar example shows the living colors. Examples in the Museum from Ceylon, Siam, and Cochin China appear to have been colored in life as this figured specimen was.

Known now from Ceylon and India over most of southeastern Asia, and Celebes, Sumatra, and Flores.

For an excellent account of the habits of this species, see Flower, Proc. Zool. soc., London, 1899, p. 906-908.

Kaloula baleata (MÜLLER).

Müller, Verh. Bat. genootsch., 1836, p. 96. Boulenger, Cat. Batr. Sal. Brit. mus., 1882, p.169-170.

Type locality:- Van Oort and Müller discovered this species on a trip taken through the Preanger early in 1833. Müller wrote his notes on it, and sent them back to Batavia for publication from Lewie Gadja. He reported finding about fifty examples near this town.

This species is locally quite common in west Java. In the city of Batavia its loud screams may sometimes be heard in the roadside ditches during the rains, late in the evening. I have three examples taken there, where, however, they were very shy. In the daytime they stay largely in the hollows of fallen bamboos. I never met with this species during several months at Buitenzorg. Van Kampen told me he had found it sparingly at Tjilatjap.

This species is unknown from the mainland, but is reported from the following islands:- Philippines, Sumatra, Nias, Borneo, Java, Sumba, and Celebes.

\section{Bufo andersonii Bodlenger.}

Bodlenger, Ann. mag. nat. hist., 1883, ser. 5, 12, p. 163. Fauna. Brit. India. Rept. Batr., 1890, p. 504.

This toad seems to be the common garden toad of the dry regions of Upper India. Specimens were taken at Jeypore during November, 1906, where it was fairly common.

This species was first accurately characterized by Anderson (Proc. Zool. soc. London, 1871, p. 203), but he referred his specimens to Bufo pantherinus auct. These examples were from Agra, and were also used by Boulenger in the description of $B$. andersonii, as well as examples from Ajmere, Tatta, and some with no more definite locality than "India." It is therefore impossible to establish a precise type locality.

The species is known from Upper India and Arabia.

Bufo himalayanus (GưNTHER).

Günther, Reptiles Brit. Ind., 1864, p. 422. Boulenger, Cat. Batr. Sal. Brit. mus., 1882, p. 305-306.

There are three large specimens typical of this species which were sent to the Museum from the Koolloo Valley, India, by the Rev. M. M. Carlton. The 
small indistinct tympanum, and low blunt cranial ridges serve to distinguish this species from $B$. melanostictus.

First described as a Himalayan subspecies of the latter form, it is now known from a number of stations along India's upper frontier, always, however, among the hills. B. bankorensis Barbour from Formosa is surprisingly closely related.

Bufo melanostictus ScHNEIDER.

Schneider, Hist. Amphib., 1799, pl. 3, p. 216. Bodlenger, Cat. Batr. Sal. Brit. mus., 1882, p. 306-307. STEJNEGER, Bull. 58, U. S. nat. mus., 1907, p. 72-75.

Type locality:- While the species was described from examples from east India, Schneider also remarks that he had a Chinese specimen in the Blochian museum.

With considerable material before me, I am quite unable to find any constant differences which would serve to distinguish specimens from the many localities where this toad occurs. During 1906-07 the following specimens were taken:- five from Calcutta, two from Kyouk-meoung, a town on the Irrewady above Mandalay, one large individual from Penang, three from Batavia, and twenty-one from Buitenzorg.

Besides these I have examined three from Hong Kong (M. C. Z. 1,437, 2,129); three from Saigon (M. C. Z. 1,318); one from Amballa (M. C. Z. 450); and one very large specimen from the "East Indies" (M. C. Z. 1,313); also seven specimens, taken by Mr. Agassiz's expedition to the Maldives, from Addu Atoll; and ten from Male Atoll. The latter series shows well the changes which take place during individual growth. The young begin with a smooth flat crown, this is followed by small black prominences serially arranged. These extend, fuse, and finally grow to the characteristic heavy cephalic ridges. At about the time of fusion the concavity of the crown is noted; during adult life this seems to increase slowly, and in old individuals it is very much depressed. Bryant had specimens from Batavia, Buitenzorg, and Depok.

This toad ranges from Celebes, through continental Asia to China and Formosa. It is also known from the Philippines, Sumatra, Banka, Riouw Island, Natuna, Borneo, Java, and Madura. Bleeker, as van Kampen remarks (Zool. ergeb. Max Weber's Reise, 1907, 4, 2, p. 416), has also reported it from Celebes under the synonymous name Bufo scaber. He may have had specimens of either $B$. celebensis or B. biporcatus. 
Bufo biporcatus Tschodr.

Plate 6, fig. 21, and Plate 8, fig. 35.

Tschudi, Class. Batr., 1838, p. 51 (not p. 88). Boulenger, Cat. Batr. Sal. Brit. mus., 1882, p. 311. (ref. to Tschudi, p. 88, nomen nudum).

Type locality:- Java, collection of Kuhl.

Curiously enough we did not once meet with this species in Java, but Bryant got one at Buitenzorg (fig. 35). There is a single young example (fig. 21), from Makassar, Celebes (Barbour coll.).

Van Kampen in his table of distribution of East Indian Amphibia (Zool. ergeb. Max Weber's Reise, 1907, 4, 2,) records this species from the mainland of Asia ( $c f$. also Boulenger, Fauna Brit. India. Rept. Batr., 1890, p. 507). Among the islands it occurs on Sumatra, Borneo, Java, Madura, Lombok, and Celebes. Bleeker has reported it from Bali, and this is probably correct.

\section{Bufo cavator BARBOUR.}

Plate 6, fig. 22.

Barbodr, Proc. Biol. soc. Wash., 1911, 24, p. 21.

Type locality:- Ampenan, Lombok.

This species is known from the type alone, from which the figure was drawn.

Bufo asper Gravenhorst.

Gravenhorst, Delic. Mus. zool. Vratislav., 1829, p. 58. Boulenger, Cat. Batr. Sal. Brit. mus., 1882, p. 313 .

Type locality:- Java.

This large toad does not seem to be common anywhere. It is very rare in Batavia, and constant search, the offering of special inducements to the natives, etc., brought in only three adults at Buitenzorg. Here also Bryant got the same number as well as an additional one at Gunung Bunder, Mt. Salak.

It occurs on Sumatra, Borneo, and Java, as well as on the mainland up to Tenasserim.

\section{Bufo borbonicus (BoIE).}

Plate 8, fig. 33.

Bore, Isis, 1827, p. 294. Boulenaer, Cat. Batr. Sal. Brit. Mus., 1882, p. 286-287. Horst, Notes Leyden mus., 1883, 5, p. 236.

Type locality:- Java.

Boulenger, in his synonymy of this species, mixed two very widely different species, this one and Bufo cruentatus Tschudi. Both of these were recognized by Tschudi as being wholly unlike. Van Kampen (Zool. ergeb. Max Weber's Reise, 1907, 4, 2, p. 416) says in a note "Bufo cruentatus: auch diese Art gibt 
Peters (loc. cit.), nicht aber Boulenger, für Borneo an. Peters trennte sie aber nicht von $B$. borbonicus, so dass nicht ersichtlich ist, welche der bieden Arten er meint." Turning now to the work of Peters (Ann. Mus. civ. Genova, 1872, 3, p. 43) to which van Kampen refers, we find that he not only mentioned both species separately, but did not even consider them congeneric. As a matter of fact, Boulenger was probably correct in not including them in the Bornean fauna, since Peters evidently had a mixed collection which contained, besides these, other things which never saw Borneo.

Bryant got one example at Buitenzorg.

Known certainly from Java and Sumatra.

Bufo cruentatus Tschudi.

Plate 8, fig. 34 .

Tschodi, Class. Batr., 1838, p. 52. Horst, Notes Leyden mus., 1883, 5, p. 236.

Type locality:- "India orient. Mus. Lugd."

Boulenger's reference to Tschudi given on page 286 of the Catalogue of Batrachia Salientia British museum 1882, is "Batr. p. 88." This refers to a pure nomen nudum, and such deseription as is given is comprised in a few lines, which are found in Tschudi's discussion of the genus Bufo. The type locality was undoubtedly Java as Horst mentions specimens in the Leyden museum taken by Kuhl and van Hasselt, and by Boie and Maclot.

Bryant found this toad twice at Tjibodas, where it is very rare.

I have noted the confusion which has placed this species as a synonym of $B$. borbonicus Boie under the remarks on that species.

Bufo cruentatus is probably confined to Java.

Tschudi (p. 50) says "Bufo calamitus, mehr dem norden Europas angehörig ***wesshalb er von Schneider Bufo cruentatus genannt wurde." Schneider really used the name Bufo cruciatus (vide Boulenger, Cat. Batr. Sal. Brit. mus., 1882, p. 294)

\section{Bufo obscurus (Barbour).}

Plate 6, fig. 20.

Barbour, Proc. Biol. soc. Wash., 1904, 17, p. 51.

Type locality:- Sarawak.

This species is not a Nectes, to which genus it was originally assigned. The very small and inconspicuous paratoid glands shown in the figure were not seen when the original description was penned. 
Hyla dolichopsis (COPE).

Cope, Journ. Acad. nat. sci. Phila., 1867, ser. 2, 6, p. 204. Boulenger, Cat. Batr. Sal. Brit. mus., 1882 , p. 384-385. VAN KAMPEN, Nova Guinea, 1906, 6, p. 171-172.

Type locality:- Ambon.

Nine examples were taken at Sorong, New Guinea, and two at Manokwari. An enormous specimen, nearly five inches from nose to vent, was found in Ternate.

Boettger (Zool. anz., 1895, 18, p. 136-137) designates the Ternatian examples by a special subspecific name, $H$. $d$. tenuigranulata. Among some of the Papuan examples are found nuptial asperities of the shape which Boettger has described as peculiar to those from Ternate; while in the figured example which we took in Ternate the tympanum is greater in diameter than are the digital dilations. This condition is the same as that seen in Papuan specimens, and the opposite of what Boettger has noted for the individuals from the Moluccan Islands. The Sorong series shows that the species is subject to considerable variation even in a limited locality.

This is the most widespread Hyla of this whole region. It has very recently been reported from Java, where it was artificially introduced into the Buitenzorg Botanical Garden; before this it was known from Timor, Talaut, the Moluccas generally, Papuasia, Australia, and some other islands to the eastward.

\section{Hyla kampeni BARBOUR.}

Plate 5, fig. 13.

Bull. M. C. Z., 1908, 51, p. 324.

Tongue subcircular, slightly nicked; and free behind. Vomerine teeth in two short groups between the middle of the choanae, the interspace separating them as wide as one of the groups. Snout rounded, tympanum round; its diameter is equal to two thirds of the distance from eye to nostril. Rudiment of pollux present. Fingers webbed as follows:- second digit two thirds, third wholly, fourth almost wholly, fifth wholly. The toes are all wholly included in the extent of the web. Dises large, almost as large as tympanum. Skin smooth above, belly and lower side of thighs finely granulate. Upper surfaces greenish brown (dull green in life), lower surfaces unmarked yellow.

Type:- No. 2,433, M. C. Z., a single specimen, taken at Wahaai, Ceram, January, 1907, by T. Barbour.

Hyla kampeni is nearly related to $H$. montana Peters and Doria. It may be readily distinguished by its larger tympanum, greater extent of webbing between the toes, and a more slender build. It is also evidently different from $H$. am- 
boinensis Horst and $H$. ruepelli Boettger, which we might expect to find in this locality.

Hyla dolichopsis (Cope) and H. vagabunda Peters and Doria are the only other members of the genus which have been previously reported from the island of Ceram.

Hỵla (Hylella) ouwensii Barbour.

Plate 7, fig. 25.

Bull. M. C. Z., 1908, 51, p. 325.

"Head short; snout squarish; loreal region rather concave; tympanum extremely small, about one fifth diameter of eye; the tibio-tarsal articulation reaches a considerable distance beyond the snout. Fingers two thirds webbed, toes three fourths webbed. Skin of back rough, but without enlarged tubercles, skin on belly with very many small tubercles; these are largest and most abundant about the anal region, whence the series extends out onto the inner sides of the thighs for about half their length. Upper parts of head, body, thighs, shins, feet, and arms of a grayish ground color vermiculated and blotched with blue, in alcohol, green in life; more ashy gray shows on the limbs than on the back. Throat white, belly and lower sides of hind limbs yellowish.

Allied to Hyla (Hylella) nigromaculata (Meyer).

Type:- No. 2434, M. C. Z., a single specimen, about an inch and a half long, taken at Pom, north coast of Jobi (Japan) Island, Geelvink Bay, Dutch Papua, February, 1907. T. Barbour, collector."

Two other species of this genus, also lacking in vomerine teeth, have been described from Jobi Island; while from the great "mainland" of Papua but a single species is known. In the preliminary paper (loc. cit., p. 324) I pointed out why these species might advantageously be included in the genus Hyla. Van Kampen (Nova Guinea, 1906, 5, 6, p. 176) showed that certain true Hylas lack vomerine teeth in the young condition. As this might, therefore, be a character which persisted in some species, and as Hylella from its distribution could not be considered a monophyletic genus, it seemed wise to combine the two groups, as van Kampen suggested.

\section{Megalophrys montana WAGLER.}

Plate 7, fig. 30 .

Wagter, Nat. syst. Amphib., 1830, p. 204, . Boulenger, Cat. Batr. Sal. Brit. mus., 1882, p. 442-443. WeBEr, Ann. Jard. bot. Buitenzorg, 1898, 15, suppl. 2, p. 5.

Type locality:- Java.

This species is not uncommon in Java, locally at elevations of over 4,500 
feet. Two adults and a young one were taken at 5,000 feet on the Papandaiang, near Garut; two on the slopes of the Pangerango at about 4,500-4,800 feet; and six adults on the Gedeh near the Mountain Gardens at Tjibodas. I feel almost sure in saying that the lower limit of the occurrence of this amphibian is nearly coincident with the lowest level at which there is a general occurrence of tree ferns. Bryant got two on Mt. Salak, and seven on Mt. Gede, about Tjibodas, at altitudes of from 4,500 to 6,400 feet.

The peculiar larvae were sought in vain. They have been carefully described by Weber (loc. cit.). Their habits are well considered by Annandale, whose field notes Boulenger (Fasc. Malay. Zool., 1903, 1, 1, p. 132) has used. Bryant, however, got eight at Tjibodas. These were taken from a small sluggish pond, not from a rushing stream, which they have usually been reported as frequenting. Van Kampen (Nat. tijd. Ned. Ind., 1909, 69, 1, p. 27) has added some observations on specimens taken in a similar situation, which are of special value in view of the very great interest which has been aroused by the remarkable form of this curious larva.

As Flower (Proc. Zool. soc. London, 1899, p. 913) notes for M. nasuta, the specimens vary in color individually, and by frequent changing they always show tints which harmonize wonderfully with dead leaves, in which they lie hidden during the daytime. The colored figure, which has been made from my field notes, shows this resemblance very well. In these notes specimens are described which in life are "Uniform violet above; belly rusty, mottled with dark brown." ** "Immaculate violet brown above with a pair of dark spots on the back, belly almost white with darker marblings." ** "Violet with many varied black markings above, belly black, or brown, or violet gray with streaks and spots of black."

The largest example measured $5^{\prime \prime}$ from snout to vent; the smallest, a little over an inch. Boulenger recorded a Javan individual in the British museum which "bears a slight dermal appendage on the tip of the snout." This is not the case with any one of this series.

The range of this form includes the mainland, Philippines, Sumatra, Borneo, and Java.

\section{Megalophrys hasseltii (Tscrudi).}

Tschudi, Class. Batr., 1838, p. 81. Boulenger, Proc. Zool, soc. London, 1908, p. 425.

Type locality:- Java.

Tschudi did not actually describe this species; but as he made his genus Leptobrachium monotypic, we can use the generic characterization, which, 
coupled with the fact that his material came from Java, makes it quite certain as to what species he really had.

On page 43 he speaks of, and describes briefly, Septobrachium, using, how-

ever, no specific name. This spelling is obviously a typographical error, in that the name is correctly given on page 81 ; for this reason it has no standing in nomenclature.

The reasons for uniting Xenophrys and Leptobrachium with Megalophrys, are given in Boulenger's convincing paper on the subject (Proc. loc. cit., p. 425).

Neither Bryant nor I met with this interesting frog; but, thanks to my friend, Major P. A. Ouwens, I have received three fine adults, and four larvae showing various stages of development. These tadpoles have been studied and figured by van Kampen (Nat. tijd. Ned. Ind., 1909, 69, 1, p. 27, pl. 1, fig. 1).

The series before me is from Pengalongan, Malabar, Java. The species is confined to the mountains wherever it occurs.

\section{SAURIA.}

Gymnodactylus marmoratus DuMeril et Bibron.

Dumeril et Bibron, Erpet. gen., 1836, 3, p. 426, pl. 34, fig. 1. Boulenger, Cat. lizards Brit. mus., 1885,1, p. 44.

Type locality:- Java.

Boulenger credits this name to (Kuhl) Fitzinger, Neue class. rept., 1826, p. 47. The name is here a nomen nudum, and is apparently based on a name received in litt. from Boie. Stejneger, who has Isis at hand, writes me regarding this case the following:- "We next hear of it in Isis for 1827, but not in the paper by F. Boie (H. Boie's brother), but in one by Schlegel, severely criticising Fitzinger's work of 1826. We find the following: p. 289 'Herrn Boies neue Genera folgen nun in systematische Ordnung.

p. 290 . . . . . . . .

'3) N. G. Goniodactylus Kuhl. Species: 1) marmoratus Kuhl. n. sp. 2) Ascul. stenodactylus Licht._-"

The name is thus also a nomen nudum here as well as in Gray, Griffith's Anim. kingdom, to which Boulenger (loc. cit.) refers. Dumeril and Bibron were then the first to describe and figure the species, and the name must, of course, be credited to them.

The lizard is not a rare one, and is generally found under stones or logs in more or less open country. I have seen a few examples in cracks in the bark of trees in the forest. My series of six came from Buitenzorg. Bryant got one at 
Gunung Bunder, Mt. Salak; four in the Megamendung Mountains, west Java; two at Depok; one at Buitenzorg; and one at Tjibodas.

Gymnodactylus lateralis WERNER.

Werner, Verh. zool. bot. ges. Wien, 1896, 46, p. 11, pl. 1, fig. 4.

Type locality:- Sumatra.

One specimen of this rare gekkoid was obtained by exchange from the American museum of natural history. It is from Sumatra, the only region whence the species comes.

Hemidactylus frenatus DUMERIL ET BIBRON.

Dumeril et Bibron, Erpet. gen., 1836, 3, p. 366 . Boulenger, Cat. lizards Brit. mus., 1885, 1, p. $120-121$.

Type locality:- "Cette espece habite l'Afrique australe, et parait etre repandue dans touts l'archipel des grandes Indes." Mention of specimens is made from the Cape of Good Hope, Madagascar, Mauritius, Ceylon, Ambon, Timor, Java, Marianne Island, Bengal.

This wide-ranging form is represented in the collection by specimens collected by the writer at Jeypore, Delhi, and Calcutta, India; Rangoon and Tigyaing, Burma; Saigon, Cochin China; Buitenzorg, Java; various localities on Halmahera and Obi Islands in the Moluccas; at Saonek, Wiagiu; and at Sorong, Manokwari, Djamna, and Humboldt's Bay in New Guinea.

Ranges through China, southeastern Asia generally, East Indies and Papuasia, Queensland, St. Helena, and Korea.

\section{Hemidactylus gleadovii Murray.}

Murray, Zool. Sind. 1884, p. 360, pl.-, fig. 3. Boulenger, Cat. lizards Brit. mus., 1885, 1, p. 129.

Type locality:- Sind, India? Murray, loc. cit. (not seen).

Three specimens taken in Lucknow, one in Calcutta, and one from Mandalay. The Museum has six (No. 3,242) from Bengal.

\section{Hemidactylus bowringii (GraY).}

Gray, Cat. lizards Brit. mus., 1845, p. 156. SteJneger, Bull. 58, U. S. nat. mus., 1907, p. 176-178.

Type locality:- unknown.

A number of examples from the thatched roofs of Butiya's houses in the valley of the Teesta River in the border of Bhutan and one example from Schwegu, Upper Burma.

Occurs in parts of India and Burma; Formosa and Riu Kiu Islands. 
Hemidactylus garnotii DUMERIL ET Bibron.

Dumerit et Bibron, Erpet. gen., 1836, 3, p. 368. Boulenger, Cat. lizards Brit. mus., 1885, 1, p. 141.

Type locality:- Tahiti.

Three examples from Buitenzorg, Java.

Occurs sporadically in the Malay Archipelago; and also in Sikkim, Burma, Philippines and in some of the South Pacific Islands.

Cosymbotus platyurus (SCHNEIDER).

Schneider, Amphib. physiol., 1792, 2, p. 30. SteJNEGer, Bull. 58, U. S. nat. mus., 1907, p. 178-179.

Type locality:- not given.

Of this wide-ranging form specimens were taken in Batavia and Buitenzorg, Java; at Patani, Halmahera; and at Sorong, New Guinea. It was observed commonly throughout the East Indies. Bryant had one example from Buitenzorg.

\section{Peropus mutilatus (WiegmanN).}

Wiegmann, Herpt. Mex., 1834, 1, p. 54. Bodlenger, Cat. lizards Brit. mus., 1885, 1, p. 148. STeJNeGER, Bull. 58, U. S. nat. mus., 1907, p. 180.

Type locality:- Manila.

Boulenger dates this name from Wiegmann, Nova acta, Acad. Leop. Carol, $1835,17,1$, p. 238 . While the Mexican herpetology is dated 1834, there are in it references to the Nova Acta, 17, which apparently was issued a year later. It is possible that the references, as they are simply made to the part and not to the page, were put in from a proof; and that Nova acta, 17, really did not appear until a year after the other book, which as it stands would seem to have been wrongly dated, and not to have appeared itself until 1835. For this reason it seems better to take the dates as they stand, and not to heed the allusions made in "1834."

A considerable number were taken at Buitenzorg.

\section{Peropus oceanicus (Lesson).}

Lesson, Voy. Coquille. Zool. 1, 1830, 2, 1, p. 42, pl. 2, fig. 3. Boolenger, Cat. lizards Brit. mus., 1885, 1, p. 152.

Type locality:- Tahiti and Borabora.

A single specimen from the crevice in the bark of a tree at Djamna, Dutch New Guinea.

Ranges widely in the Moluccas, New Guinea, Polynesia.

Peropus interstitialis (Oudemans).

Oddemans, Semon's Reise. Zool., 1894, 5, p. 134.

Type locality:- New Guinea.

Pratt took a large example at Fak Fak. The species is confined to Papua. 
Gekko gecko (LinNe).

Linnf, Syst. nat., ed. 10, 1758, 1, p. 205. Bodlenger, Cat. lizards Brit. mus., 1885, 1, p. 183.

Type locality:- "Habitat in Indiis, frequens etiam in domibus."

Specimens in hand are from Buitenzorg, Java; from Katha and Thaybeitkyin, Burma. On the mainland it is common in houses, but also found in hollow trees in the forest. In Java it is rare. Bryant got only two from Buitenzorg, and one from Depok. It is not, however, absent from Java, as Werner would have us believe, when he claims that $G$. stentor replaces this species in Java; whereas it occurs on Sumatra to the exclusion of the other species.

Gekko stentor (CANTOR).

Cantor, Cat. Malay. rept., 1847, p. 18. Boulenger, Cat. lizards Brit. mus., 1885, 1, p. 184.

Type locality:- Pinang.

Common about Buitenzorg. I got a number there; while Bryant also got one, as well as ten from Daru, Bantam, and the same number from Depok.

Gekko vittatus HouTTUYN.

Houtruyn, Verh. Zeeuw. gen. Vlissingen (Middleburg), 1782, 9, p. 325, pl. -, fig. 2. Boulenger, Cat. lizards Brit. mus., 1885, 1, p. 185.

Type locality:- "De Afkomst is zekerlyk uit de Indiën."

This species is represented in the collection by a large example, quite typical, from Ambon; another from Wahaai, Ceram; a series of twelve from Djamna, near Humboldt's Bay, New Guinea; and one from Ansus, Jobi Island. There are specimens from Faro Island, Solomons in the Museum. The specimens from the two places last mentioned are typical of Gekko bivittatus (Dum. \& Bibr.), which Boulenger relegates to subspecific rank. As the two forms overlap in range, in fact, each seems to occur more or less promiscuously over the whole area where the species is found, it seems to represent the case more fairly to consider the whole series as belonging to one variable species, and to recognize no subspecies at all. The difference lying in color, not in structure, they can both hardly be true species; and subspecies can not occur distributed in this way.

\section{Ptychozoon kuhli Stejneger.}

Plate 7, fig. 24.

StejNeger, Proc. Biol. soc. Wash., 1902, 15, p. 37. Bodlenger, Cat. lizards Brit. mus., 1885, 1, p. 190.

Type locality:- Originally described by Creveldt (Mag. naturf. fr. Berl., 1809, 3, p. 266, pl. 8), as Lacerta homalocephala. 'Stejneger gave a substitute name after the founder of the genus, as Creveldt's was preoccupied. I do not know the original description from autopsy. 
On arrival at Buitenzorg, search began at once for the "Flying gekko." In a few days living specimens began to be brought in by the natives, and we were shown how to find them as they rested by day in the chinks and crannies of rough-barked trees. This is never a "house-lizard." We never heard any of the many specimens we kept alive utter a sound, nor did they ever rest with the skin flaps extended. They may be able to do so, however; and when in this condition, they would be marvellously inconspicuous. As for flying with such weak supports, this struck us at once as being both impossible and ridiculous. Individuals were teased into jumping from a table, were dropped from several feet up in the air, and were in every way induced to try to use what has so often been called their parachute. They never did this

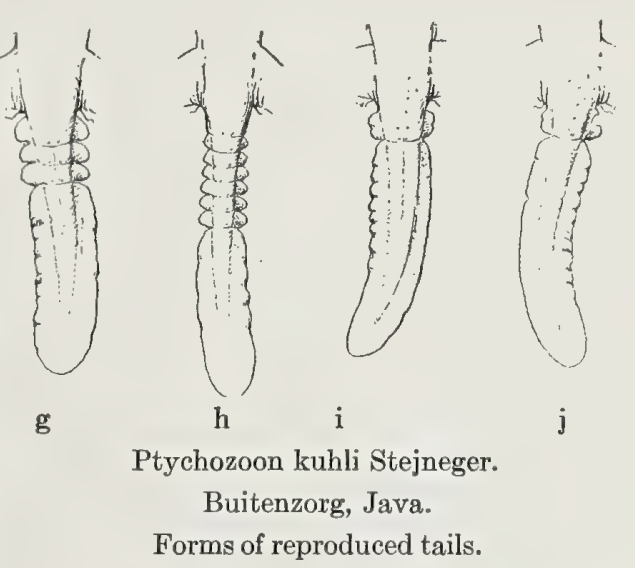
once. Annandale, who had only a single young one alive for observation, came to the same conclusion (Ann. mag. nat. hist., 1905, ser. 7, 15, p. 32). Annandale also exposed the error arising from Wallace's figure of the flying frog. This error was most unfortunate as it became firmly fixed in zoölogy on the authority of a great naturalist.

The two small white eggs of Ptychozoon are always found stuck together in pairs, usually against the wood under the bark of trees. Curiously enough, the eggs of Aristelliger are laid in just the same way; and the eggs of the two species are so alike in size as to be almost indistinguishable.

The period of incubation for the eggs of Ptychozoon is very long. It has been discussed by Annandale, who has also given an excellent account of egglaying (Boulenger, Fasc. Malay. Zool., 1903, 1, p. 150, quoting Annandale's field notes). Annandale has published other notes on habits, and on the regeneration of the tail (Journ. Asiat. soc. Bengal, 1904, 73, suppl., p. 22). Gadow (Amphibia and reptiles, 1901, p. 505) says that the lobes and flaps of skin are apparently to assist adhesion. This is almost surely not the case, since by far the greater part of the time they are closely folded along the sides of the body. They may possibly assist in rendering the creature less conspicuous at certain rare momentary crises. I believe it far more probable that these developments serve at present no purpose whatever. They may be taken to represent, perhaps, 
the result of an inherited tendency to vary in a definite direction, coupled with what Cope has called superabundant growth force. We see incipient lateral flap-like outgrowths of skin in other genera of Gekkonidae; in this one the growth process has carried the development far beyond the conditions seen among the other forms. Such growth is comparable to that which shows itself in the curling tusks of the Babirusa, which are perfectly useless; in the enormous curved tusks which may have been a vital hindrance to the persistence of the Mammoth; or in any other one of the hundreds of examples which may be drawn from among both vertebrates and invertebrates, to show that nature often seizes hold of some one feature or character and complicates it or increases its development beyond all usefulness.

When the tail is lost, instead of the regenerated portion showing the crenulated or lobate outline which extends almost to the tip in P. kuhlii, and quite to the tip in $P$. horsfeldii, it grows out with a single unemarginate wide fringe of skin. Thus specimens with reproduced tails from localities where both species occur could not be separated. This is an excellent example of the more simple condition always visible in a reproduced tail. Squamation here invariably consists of small pavement-like scales, quite uniform in size, where the original may have shown ornamentation either with whorls of enlarged tubercles, or in other ways. In this tail, the squamation and márgin both show far less complication in the new growth than in the original. This may or may not be a reversion to a more primitive or ancestral condition. There is no proof one way or the other.

For some strange reason this lizard bears, in Java, a form of native name usually confined to snakes. It is called Ular-pa'atek or Ular-papatek. The word Ular is invariably used with some qualifying word for a snake-name, as Burung is invariably used for birds. I know of no such generic term for lizards or mammals which is used in the same way.

The material preserved consisted of fifty-two examples of all ages from Buitenzorg. Bryant had several also from the same locality.

Kuhl's Fringed lizard has been found in Java, Sumatra, Engaño, Penang, and the Malay Peninsula to southern Burma.

Horsfield's Fringed lizard occurs on the Malay Peninsula and in Borneo and the Natuna Islands. It is recorded from the Riu Kiu Islands, but Stejneger naturally doubts the accuracy of so improbable a record (Bull. 58, U. S. nat. mus., 1907, p. 170). 
Draco volans LinNé.

L.INnk, Syst. nat., ed. 10, 1758, 1, p. 199. Boulenger, Cat. lizards Brit. mus., 1885, 1, p. 256.

Type locality:- "Habitat in India, Africa."

This wonderful little creature, the $H \bar{a} p-H \bar{a} p$ of the Javanese Malays, -is extremely common about Buitenzorg, whence came the thirty specimens collected in 1906-1907. Bryant found it equally abundant there, and sent back twenty-five; he took two others at Gunung Bunder, Mt. Salak; and one at Depok. It is strictly a lizard of the lower regions of the island, and it does not occur about Tjibodas or Sindanglaia, or at an altitude above $3,500-4,000$ feet.

\section{Draco fimbriatus KUHL.}

KvHL, Beitr. zool. und vergl. anat., 1820, p. 101. Boulenger, Cat. lizards Brit. mus., 1885, 1, p. 265.

Type locality:- "India orientalis."

This flying lizard is much rarer than the common D. volans. Bryant got five examples at Buitenzorg. It can be easily distinguished from the other by the pure white under surfaces of the "wing"; and, of course, it grows to a far greater size. One of this series (collector's No. 558) has a minute tympanum, almost indistinguishable; in this character it is widely different from that typical of the species.

\section{Gonyocephalus chamaeleontinus (LAURENTI).}

Ladrenti, Syn. Rept., 1768, p. 47. Bodlenger, Cat. lizards Brit. mus., 1885, 1, p. 285.

Gonyocephalus kuhlii (Schleg.). BovLenger, loc. cit., p. 286.

Type locality:- "Habitat in America."

This species is a variable one. With a considerable series at hand, I have concluded that G. kuhlii is not a valid species; and, although I have no Sumatran specimens, I strongly suspect that Schlegel's G. (Lophyrus) sumatranus should be added to the synonymy as well.

The 1906-1907 collecting brought back two examples from Sindanglaia; one from Sukabumi; two from Tjibodas; and one from Tjiserupan. Bryant had six from Tjibodas. In this lot were individuals of all ages, including several large, fully adult specimens. Some had the ventral scales keeled quite distinctly, others less so; while a single, large one had them almost smooth. The projecting supraciliary border is more or less developed; varying, as does also the nuchal crest, both in height and in position anteriorly; so that no definite line can be drawn to separate groups of individuals. 


\section{Gonyocephalus dilophus (DUMeriL ET BiBron).}

Dumeril et Bibron, Erpet. gen., 1837, 4, p. 419, pl. 46. Boolenger, Cat. lizards Brit. mus., 1885, 1, p. 290.

Type locality:- New Guinea.

A fine adult of this remarkable species collected by Mr. A. E. Pratt in the Aru Islands is in the Museum series.

\section{Gonjocephalus modestus MEYER.}

Meyer, Mon. Berl. akad., 1874, p. 130. Boulenger, Cat. lizards Brit. mus, 1885, 1, p. 294.

Type locality:- Jobi Island.

Of the two examples examined, one came from Pom, Jobi Island, Papua; the other was purchased abroad, and comes from the Astrolabe Bay, German New Guinea. They are both of practically the same adult size, some $300 \mathrm{~mm}$. in length; but the serration on the dorsal aspect of the tail is much more pronounced in the specimen last mentioned than in the other.

\section{Calotes cristatellus (KणHL).}

KuHL, Beitr. zool. und vergl. anat., 1820, p. 108. Bodlenger, Cat. lizards Brit. mus., 1885, 1, p. 316.

Type locality:- unknown.

Bryant took one at Buitenzorg, and there were six in my collection from near Garut, Java. This may be known as C. cristatellus cristatellus (Kuhl).

Other examples - six from Ternate, one from Ceram, and four from Halmahera - often vary considerably from the condition seen in the Javan specimen. Javan examples can be matched in the Moluccas, but only rarely. Boulenger has noted the differences which may occur (loc.cit., p. 317). Moluccan examples probably represent a valid geographic race, and may be known as Calotes cristatellus moluccanus Peters, (Mon. Berl. akad., 1867, p. 171).

The Celebes examples should probably stand as Calotes cristatellus celebensis Günther (Proc. Zool. soc. London, 1873, p. 168).

\section{Calotes mystaceus (DUMERIL et Bibron).}

Dumeril et Bibron, Erpet. gen., 1837, 4, p. 408. Boulenger, Cat. lizards Brit. mus., 1885, 1, p. 325.

Type locality:- Burma.

This species was seen commonly on fences and in garden shrubbery at several places in Upper Burma. Four from Mandalay were preserved.

\section{Calotes jubatus (DUM. \& BtrR.).}

Plate 6, fig. 23, egg.

KAUP, Isis, 1827, p. 619. Boulenger, Cat. lizards Brit. mus., 1885, 1, p. 318.

Type locality:- Java.

This is a common tree-lizard about Buitenzorg, where six were preserved in 
1906. Bryant got many more:- eighteen from Buitenzorg; seven from Gunung Bunder, Mt. Salak; two from Tjibodas; one from Depok; and one from Daroe, Bantam.

The curious spindle-shaped eggs are often found in loose earth about tree trunks or in decaying vegetable matter, such as old leaves or the rubbish in hollow trees or logs.

\section{Calotes versicolor (DAUDIN).}

Daudin, Hist. nat. rept., 1802, 3, p. 395, pl. 44. Boulenger, Cat. lizards Brit. mus., 1885, 1, p. 321.

Type locality:- Daudin based his description on two specimens in the Paris museum. He did not mention whence they came. He identifies them, however, with a lizard which Seba figured as coming from Brazil. Daudin undoubtedly believed that he was describing a lizard from tropical South America.

Individuals from Calcutta; the Teesta Valley, Sikkim; Mandalay; and Saigon, which were got in 1906-1907, do not show constant variations correlated with the places where they were found.

\section{Dendragama fruhstorferi BoETTGER.}

Boettger, Zool. anz., 1893, 16, p. 335.

Type locality:- Tjiserupan, west Java.

An abundant species in the mountain regions at an altitude of over 4,000 feet. It is partial to sunny glades in rather heavy forest, and is rather strictly arboreal.

Both my own and Bryant's collection had large series, the latter the larger.

The species is, so far as known, confined to west Java, the only other member of the genus being found on Sumatra.

\section{Hydrosaurus amboinensis (ScHLosser).}

Plate 4, fig. 11.

Schlosser, Epist, Hornst. Abh. acad. Stockh., 1785, 6, p. 130, pl. 5, fig. 1. Barbour, Proc. Biol. aoc. Wash., 1911, 24, p. 19.

Type locality:- Ambon.

A specimen from Piru, Ceram, agrees absolutely with a topotype recently taken in Ambon and now in the United States national museum. It has been described (Barbour loc. cit.) in connection with the original description of the following species.

So far as known this form occurs on Ambon and Ceram only. 
Hydrosaurus weberi Barbour.

Plate 4, fig. 10.

Barbour, Proc. Biol. soc. Wash., 1911, 24, p. 20.

Type locality:- Weeda, Halmahera Island.

This distinct species was described on the basis of two adults (male and female) from Halmahera. A series of young examples of various ages show that the species occurs on Ternate also. Probably the examples recorded from Batjan belong here too.

This, the largest of the sail-tailed lizards, is apparently confined to the Halmahera group of the Moluccas. A head of the Philippine species, H. pustulosus (Eschscholtz), is figured for comparison (Pl. 4, fig. 9).

Varanus salvator (LAURENTI).

Laurenti, Syn. Rept., 1768, p. 56. Boulenger, Cat. lizards Brit. mus., 1885, 2, p. 314.

Type locality:- "America."

Specimens from Buitenzorg, Java, are in each of the Javan collections seen. The species is a very common, variable, and wide-ranging one. Its distribution is given in the table appended.

\section{Varanus indicus (DAUDIN).}

Daudin, Hist. nat. rept., 1802, 3, p. 46, pl. 30. Boulenger, Cat. lizards Brit. mus., 1885, 2, p. 316.

Type locality: - Ambon.

This was a common Moluccan species. Specimens were preserved from Ceram, Ternate, and Halmahera.

This species frequents mangrove, nipa, and sago swamps especially. It is not apparently fond of climbing, but can do so, though far less ably than Hydrosaurus, which is generally associated with it. It swims, of course, with ease. A small swampy pond some miles to the westward of the town of Ternate lies in what is apparently the bed of an old crater. One side is blown down, so that it may be approached at almost sea-level, while otherwise it is shut in by a perfect amphitheatre of hills. About the shores of this lake, these monitors occur in great droves; and the helter-skelter rush for the edge of the pond on the part of these great lizards as we approached reminded one only of the pictures of Amblyrynchus on the rocky shores of the Galapagos Islands, living under conditions so totally different.

Mr. A. E. Pratt's collection brings in one from the Aru Islands.

The table (p. 197) may be consulted for the distribution. 
Varanus kordensis MEYer.

Meyer, Mon. Berl. akad., 1874, p. 131. Boulenger, Cat. lizards Brit. mus., 1885, 2, p. 322.

Type locality: - Korido (Kordo), Wiak Island (Mysore), Schouten group.

Two fine examples from the Aru Islands, taken there by Mr. A. E. Pratt. They are both coal-black above and below.

Takydromus sexlineatus DAUDIN.

Daddin, Hist. nat. rept., 1802, 3, p. 256, pl. 39. Boulenger, Cat. lizards Brit. mus., 1887, 3, p. 4.

Type locality: - unknown.

The specific name quadrilineatus for this species was based on what was without doubt the same species, and occurs in Daudin on an earlier page (252). According to the usage of some writers, ornithologists especially, this name, from the mere fact of its place in the volume, becomes ipso facto the only available name for the species. It seems, however, better to follow the rule that the first reviser can designate the name by which the species shall be known. All authors have used sexlineatus. The alternative name, quadrilineatus, which seems never to have appeared in the literature but once, is thus sharply disposed of.

This is an extremely common species in open country, and both Bryant and I got large series in west Java.

\section{Tiliqua gigas (SchNeIDER).}

Schneider, Hist. Amphib., 1801, 3, p. 202. Boulenger, Cat. lizards Brit. mus., 1887, 3, p. 144.

Type locality: - Ambon.

This species was taken twice at Ternate, and once at Wahaai, Ceram. Under the notes on Java I have expressed my doubt as to the probability that the record for that island (Berlin mus. 10,490, Bantam) is correct, even though there seems to be every semblance of accuracy.

\section{Mabuya multifasciata (KOHL).}

KuHL, Beitr. zool. und vergl. anat., 1820, p. 126. Bodlenger, Cat. lizards Brit. mus., 1887, 3, p. 186.

Type locality: - not given.

One of the most wide-ranging of the skinks ( $c f$. table). Specimens were preserved as follows:- thirty-five from Buitenzorg, Java; one from Wahaai, Ceram; seven from Patani, Halmahera; one from Gane, Halmahera; nine from Ternate; and one from Meosbundi, Wiak Island, Schouten group, which seems to be the first Papuan record for the species. It is probably not artificially introduced, as there has been very little intercourse with this place, owing to the hostility of the natives, who are even yet considered especially dangerous. 
Mabuya macularia (BLYTh).

Buyth, Journ. Asiatic soc. Bengal, 1853, 22, p. 652. Bodlenger, Cat. lizards Brit. mus., 1887, 3, p. 182.

Type locality: - "? Rungpore" India.

A common species in the suburbs of Calcutta. Two specimens preserved.

Sphenomorphus sanctus (DumErr ET BiBron).

Dumeril et Bibron, Erpet. gen., 1839, 5, p. 739. Max Weber, Zool. ergeb., 1890, 1, p. 171, pl. 14, fig. 4.

Type locality: - Java.

Boulenger (Cat. lizards Brit. mus., 1887, 3, p. 243) said that this species, "described from a young specimen in bad condition, is probably closely allied" to $S$. maculatus Blyth. Only the type was known until it was rediscovered by Weber. The species is an extremely rare one in Java, at any rate about Buitenzorg. I should say that it occurred in the ratio of about one to two hundred as compared to Mabuya multifasciata; perhaps even less often. I found but two at Buitenzorg; Bryant, on the other hand, got five at the same place.

Sphenomorphus variegatus (Peters).

Peters, Mon. Berl. akad., 1867, p. 20. Bodlenger, Cat. lizards Brit. mus., 1887, 3, p. 246.

Type locality: - Mindanao.

This species is one of the less common ones, though it is met with sparingly over a wide range. The series studied consists of two from Sorong, and one from Manokwari, Papua; one each from Ansus and Pom, Jobi Island; and one from Jeendee, Ron Island.

Sphenomorphus jobiensis (MEYER).

Meyer, Mon. Berl. akad., 1874, p. 131. Boulenger, Cat. lizards Brit. mus., 1887, 3, p. 247.

Type locality. - Jobi Island.

This species seems to be a rather rare one, at any rate in the coast regions in which we collected. Two were got at Djamna; and one each at Pom and Wooi Bay, Jobi Island. Another specimen from near Astrolabe Bay, German New Guinea, came in with a small collection recently procured.

\section{Sphenomorphus brevipes (BOETTGER).}

Boettger, Zool. anz., 1895, 18, p. 121, 129. Abh. Senck. nat. ges., 1901, 25, 2, p. 346, pl. 14, f. 3-3a.

Type locality. - Sao Konora, Halmahera.

This skink has so far been taken on Halmahera alone. A lizard from Ternate, taken in 1907, agrees well enough with the description to make it appear to be almost certainly the same species. Boettger's figure, in appearance, is not very convincing of accuracy; and the specimen does vary considerably 
from the figure, though not enough, when the agreement with the description is considered, to separate it as a distinct species.

Sphenomorphus elegantulus (Peters E Doria).

Peters e Doria, Ann. Mus. civ. Genova, 1878, 13, p. 344. Bodlenger, Cat. lizards Brit. mus., 1887,3 , p. 235.

Type locality: - Somerset, Cape York, Queensland.

A single specimen from Sorong, Dutch New Guinea, agrees well with Boulenger's description. Nevertheless, even a good diagnosis alone, without specimens for comparison, is never very convincing; and if this Sorong specimen were compared directly with authentic examples from Queensland or British New Guinea, it would very possibly be found to be different from S. elegantulus. I can not find any record that it has been previously taken in this region of Papua.

It is known from the type locality, and British and German New Guinea.

\section{Dasia olivaceum GrAY.}

Gray, Ann. nat. hist., 1839, 2, p. 331. Boulenger, Cat. lizards Brit. Mus., 1887, 3, p. 251.

Type locality:- "Prince of Wales Island," coast of Indo-China.

This wide-ranging species is another which is rare in Java. Bryant and I each got two at Buitenzorg. Its habits are those of Mabuya multifasciata; and its occurrence, judging from very many observations, can not be in the proportion of more than one to several hundred of that species.

\section{Dasia smaragdinum (LEsson).}

Plate 1, fig. 1 and 2; Plate 2, fig. 4 .

Lesson, Voy. Coquille. Zool., 1830, 2, p. 43, pl. 3, fig. 1. Boulenger, Cat. lizards Brit. mus., 1887, 3 , p. 250.

Type locality:- Oualan, Caroline Islands.

This species is common, wide-ranging, and of unusual interest. A list of the specimens preserved follows:-

From Moluccas:- two from Wahaai, and one from Piru, Ceram; six from Ternate; six from Obi, and two from Galela, Halmahera. From Papuasia:32 from Sorong, Papua; three from Manokwari, Papua; two from Humboldt's Bay, Papua; three from Saonek, Waigiu; six from Wooi Bay, Jobi Island; and one from the A. E. Pratt collection from Fak Fak, Papua. The Museum has specimens from New Britain, Formosa, the Pelew Islands, and from Ebon in the Marshall Islands. While in Japan I got from Mr. Alan Owston, of Yokahama, two specimens from Ruk, Caroline Islands, which are, of course, approximate topotypes.

Lesson's two figures, each of specimens said to be from Oualan, Caroline 
Islands, - one of which he calls Scincus smaragdinus (Pl. 3, fig. 1), and the other S. viridipunctum (Pl. 4, fig. 1),-- represent what I assume to be surely a Papuan example wrongly labelled as to locality; the second one is really from the Caroline Islands. All the specimens fall into three groups, characteristic of their geographic ranges. Thus all the specimens without a single exception from Waigiu, Papua, and New Britain have the body grass-green in life, blue in spirits, sometimes fading posteriorly to a reddish buff, which color continues along the whole tail. This race may be known as Dasia smaragdinum smaragdinum (Pl. 1, fig. 1).

Ten examples from Ebon, Marshall Islands; two from the Pelew Islands; and two from Ruk, Caroline Islands, are all alike, and unvarying in color. They are dark iron-gray, each scale with a dark centre or edge. This is the form not very accurately represented by Lesson, Pl. 4, fig. 1. It may be known as Dasia smaragdinum viridipunctum (Pl. 2, fig. 4).

The specimens from the Moluccas are as uniform, and are characterized by a light gray ground color, more or less irregularly spotted or blotched with dark brown or black. This gives a sort of pepper-and-salt appearance. The type has been designated as No. 7,481, M. C. Z., an adult from Wahaai, Ceram. The race (Pl. 1, fig. 2.) may be called Dasia smaragdinum moluccarum Barbour (Proc. Biol. soc. Wash., 1911, 24, p. 17). Curiously enough no structural characters have been found which hold for this large series which are constantly present jointly with these most striking and unexpectedly fixed color-patterns.

The young of all seem to be alike,- brownish, green spotted, and mottled with darker green; so that the single small example which I recorded from Formosa, the first known, can not be definitely placed as to its subspecies (Barbour, Proc. N. E. zoöl. club, 1909, 4, p. 65).

It may be urged that, on the evidence of Lesson's two figures, the green form as well as the other occurs in the Carolines. We must recall, however, that in the early part of the last century on long voyages specimens were not as carefully separated from each other according to locality as they are now. We know that Lesson visited Papua; and the examples of $D$. smaragdinum smaragdinum figured, and the types of other of his species indeed, doubtless are of Papuan origin. Many of the Oualan records need verification.

Leiolepisma fuscum (DUMeril et BiBron).

Dumeril eit Bibron, Erpet. gen., 1839, 5, p. 759. Boulenger, Cat. lizards Brit. mus., 1887, 3, p. 283.

Type locality:- Waigiu and Rawac Islands.

Of this common skink, which is abundant almost everywhere, both in open and in forested regions, the following material was preserved:- seven from 
Ternate; three from Ambon; one from Piru, Ceram; three from Wahaai, Ceram; five from Patani, Halmahera; fifteen from Saonek, Waigiu; eight from Sorong, Papua; twelve from Manokwari, Papua; one from Djamna, Papua; three from Jendee, Ron Island, Geelvink Bay, Papua; one each from Pom and Ansus on Jobi Island. An example from Fak Fak, Papua, came in with the A. E. Pratt series. The examples from Jendee differ from all the others in being of a darker color, and in having the dark dorsal line very strongly marked.

Leiolepisma noctua (LESSON).

Lesson, Voy. Coquille.Zool., 1830, 2, p. 48, pl. 3, fig. 4. Botlenger, Cat. lizards Brit. mus., 1887, 3, p. 256.

Type locality:- Oualan, Caroline Island.

This skink was found but once, at Sorong, northwest New Guinea. It is rare in Papua.

Leiolepisma novae-guineae (MEYER).

Meyer, Mon. Berl. akad., 1874, p. 132. Boulenger, Cat. lizards Brit. mus., 1887, 3, p. 289.

Type locality:- New Guinea.

This lizard was met with but once, when seven individuals were taken at Lawui, Obi Major Island, Moluccas. It has not been recorded from this island previously; and without any specimens from other localities for comparison, there is a possibility that these may not be typical examples of the species. They seem, however, to agree very well with Boulenger's description.

Leiolepisma pullum BARBour.

Plate 2, fig. 3.

Barbour, Proc. Biol. soc. Wash., 1911, 24, p. 15.

The type from Humboldt's Bay, Dutch New Guinea, near the frontier of Kaiser Wilhelmsland, is the only specimen known so far.

Emoia cyanurum (Lesson).

Lesson, Voy. Coquille. Zool., 1830, 2, p. 49, pl. 4, fig. 2. Boulenger, Cat. lizards Brit. Mus., 1887, 3, p. 290.

Type locality:- Tahiti.

On account of its sky-blue tail this species is strikingly conspicuous, and thus often appears to be the most common lizard in many places. In reality this is not always the case; L. fuscum, though inconspicuous, is, where it occurs, generally the most plentiful species. The following specimens of this form were preserved:- from Piru, Ceram, two; from Wahaai, Ceram, one; from Saonek, Waigiu, one; from Manokwari, Papua, one; from Djamna, Papua, one; from Jobi Island, Ansus, three, Pom, four, Wooi Bay, eleven. Another example comes from near Astrolabe Bay, German New Guinea. 


\section{Emoia mivarti (Boulenger).}

Boulenger, Cat. lizards Brit. mus., 1887, 3, p. 292, pl. 23, fig. 1.

Type locality:- Admiralty Islands.

In the shore vegetation just back from sandy beaches, this lizard was generally about equally abundant with $E$. cyanurum. The collection contains twenty-four from Djamna; nine from Manokwari; thirteen from Sorong; three from Wooi Bay, Jobi Island, and four from Pom, Jobi Island. The first three places are all on Papua, except Djamna, which is on a very near by islet.

This species was probably long confounded with the true Blue-tailed skink, and for that reason was not described until 1887, though it is both common and conspicuous.

\section{Emoia atrocostatum (LESSON).}

Lesson, Voy. Coquille. Zool., 1830, 2, p. 50, pl. 4, fig. 3. Boulenger, Cat. lizards Brit. mus., 1887, 3, p. 295.

Type locality: - Oualan, Caroline Island.

Another widespread and not uncommon species. Of the specimens examined, three came from Sorong, Papua; one from Ansus, and four from Wooi Bay, Jobi Island; one from Saonek, Waigiu Island; and one from Gane, Halmahera.

\section{Emoia baudinii (Dumeril et Brbron).}

Dumeril et Bibron, Erpet. gen., 1839, 5, p. 653. Boulenger, Cat. lizards Brit. mus., 1887, 3, p. 296.

Type locality: - New Guinea.

This lizard, while it is not uneommon in Papua, seems to be rare among the Moluccas. There are two from Wooi Bay, and four from Ansus, Jobi Island; also five from Manokwari, on the Papuan mainland. We did not meet with it elsewhere. When the British museum catalogue was written, there were only two specimens in the collection, both Papuan. Boulenger (Proc. Zool. soc. London, 1897, p. 214) says that the specimen upon which the Celebes record for this species was based is really an E. cyanurum.

\section{Emoia cyanogaster (Lesson).}

L.esson, Voy. Coquille. Zool., 1830, 2, p. 47, pl. 3, fig. 3. Bodlenger, Cat. lizards Brit. mus., 1887, 3, p. 292.

Type locality: - Oualan, Caroline Islands.

This species was found to be a rather rare one. One was got at Sorong, Papua, and another at Wooi Bay, Jobi Island. A third comes from German New Guinea by purchase. 
Emoia sorex (BOETTGER).

Boetrger, Zool. anz., 1895, 18, p. 118. Abh. Senck. nat. ges., 1901, 25, p. 243.

Type locality: - Halmahera and Batjan.

This species, which seems to replace $E$. cyanogaster in the Halmahera group of islands, was taken three times:- once at Gane and at Patani, both stations on Halmahera; and at Lawui, Obi Island, where two were caught. It has not been recorded from this island previously.

Riopa rufescens (Кнаw).

Shaw, Gen. zool., 1802, 3, p. 285. Boulenger, Cat. lizards Brit. mus., 1887, 3, p. 303.

Type locality: — "Arabia and Egypt.... shores of the Nile."!!

This species wide-ranging, but of shy and retiring habits, was only met with at Djamna, near Humboldt's Bay, New Guinea. Two specimens were found under rotting logs in the forest.

Homolepida temminckii (DUMERIL ET BiBroN).

Dumeril et Bibron, Erpet. gen., 1839, 5, p. 727. Boulenger, Cat. lizards Brit. mus., 1887, 3, p. 321.

Type locality: - Based on a specimen, incorrectly labelled, received from the Leyden museum. Locality not mentioned.

This species is abundant in west Java; and may be found under bark, stones, and similar situations, usually in open country.

It was common at Buitenzorg, where twenty-five were preserved; as well as five at Tjibodas, and two near the summit of the Papangdaiang volcano near Garut. Bryant got one at Batavia, eleven at Buitenzorg, and an enormous series on the slopes of the volcano Gede, near Tjibodas, Java. The elevation was from 4,500 to 6,000 feet.

\section{Lygosoma chalcides (LINNE).}

Linne, Syst. nat., ed. 10, 1758, 1, p. 209. Bodlenger, Cat. lizards Brit. mus., 1887, 3, p. 340.

\section{Type locality: - "Habitat in Europa australi, Africa."}

A rare species in Java; Bryant and I each found it but twice. All four specimens are from Buitenzorg. The distribution of this species is to be found in the table, and a note regarding its occurrence on Sumatra (p. 12).

Lygosoma muelleri (SCHLEQEL).

Schleger, Abbild. Amphib., 1837, dec. 1, p. 13, pl. 3. Bodlenger, Cat. lizards Brit. mus., 1887, 3, p. 338 .

Type locality: - Dutch New Guinea.

This rare lizard was found but once, when a splendid adult was taken at Wahaai, Ceram. The species coming from Papua and Ceram emphasizes 
again the point made elsewhere about the closer Papuan relationship with this island than with other of the Moluccas ( $c f$. the notes on Ceram, p. 38-40).

\section{Cryptoblepharus boutonii (DesJaRdin).}

Plate 3.

Dessardin, Ann. sci. nat., 1831, ser. 1, 22, p. 298. Bodlenger, Cat. lizards Brit. mus., 1887, 3, p. 346.

Type locality: - Mauritius.

Sufficient material is not on hand to attempt to straighten out the probable validity of many of the "varieties" which have been suggested. So far as concerns the material which Boulenger had, one can see that the "varieties" are apparently rather regularly distributed. They are probably real geographic races, for Stejneger (Bull. 58, U. S. nat. mus., 1907, p. 225) has shown that there is a definite condition found in all Bonin Island specimens, so far as seen. He had examined ten examples; and four others here, from Hahashima, Bonin Islands, confirm his observations. Regarding the other individuals which I have studied, I find nothing new to add to what has been said in Proc. Biol. soc. Washington, 1911, 24, p. 17-8.

The difference between the races pointed out in Dasia smaragdinum and in this species may be distinguished better from the colored figures than by lengthy verbal descriptions. $\mathrm{Pl}$. 3, fig. 8 , represents the type of $C . b$. balinensis Barbour. Pl. 3, fig. 5, represents the type of C. b. cursor Barbour. Pl. 3, fig. 7, is of C.b. peronii (Cocteau) from Saonek, Waigiu Island and Pl. 3, fig. 6, shows what has been called $C . b$. peronii (Cocteau) from Madagascar.

Dibamus novae-guineae DuMERIL ET BIBroN.

Dumeril et Bibron, Erpet. gen., 1839, 5, p. 834. Bodlenger, Cat. lizards Brit. mus., 1887, 3, p. 435.

Type locality: - New Guinea, almost certainly from the Dutch section.

A single typical example from Wahaai, Ceram; its presence on this island was to be expected, even if it had not been previously taken.

This curious lizard has a far wider range than for a long time was supposed. It is known from New Guinea; Waigui; Ternate, Halmahera, and now Ceram, in the Moluccas; Celebes; Sumatra; and the Malay Peninsula. This is the only land-reptile of burrowing habits, - in other words, which is not carried about fortuitously, - whose range extends from Malaya to Papua without any apparent specific differentiation. It is probably a form whose degradation began in very early times. Boulenger speaks of the genus as one "which appears to stand in the same relation to the Scincidae as Anniella to the Anguidae."

The only other Dibamus known comes from the Nicobar Islands. 


\section{SERPENTES.}

Typhlops lineatus Schlegel.

Schlegel, Abbild. Amphib., 1839, dec. 2, p. 39, pl. 32, fig. 32-34. Bodlenger, Cat. snakes Brit. mus., 1893, 1, p. 15.

Type locality:- Java; collection of Reinwardt, Leyden museum.

Color:- head and lower parts dull yellow; back with fine zigzag lines of very dark brown from 12 to 15 in number. These lines do not follow the rows of scales, but run between them. This gives the lines a wavy appearance. There is commonly a light yellow or yellowish band around the body in the region near the vent.

The early history of this species is of interest, and I must thank Dr. Stejneger for help in verifying and transcribing some references to books not available here. 1827. Boie Isis, p. 563.

" $a$. lineatus Reinw. welche dem septemstriatus Schneid. sehr nahe steht.

Vaterland Java." A nomen nudum though a type locality is referred to. 1830. Wagler, Nat. syst. Amphib., p. 196.

"Acontias lineatus Reinw." Another nomen nudum.

1831. Gray, Griffith's anim. kingdom, p. 77.

"Lined Typhlops. Typhlops lineatus Acontias, Reinw." (sic). Again a nomen nudum.

Schlegel (loc. cit., 1839, p. 39) writes, after a brief but recognizable description, "Die Abbildung, welche Herr Reinwardt, als er diese Art entdeckte, nach dem Leben machen liess, ist der Folge." This figure, however, is incorrect both as to the contour of the cephalic scales and the number of scales around the body. Günther (Reptiles Brit. Ind., 1864, p. 171) notes that this figure is incorrect. He counts 405 transverse series of scales on the body and 8 around the tail. Dumeril and Bibron (Erpet. gen., 1837, 4, p. 259) count 430 transverse series. Schlegel likewise counted 430 series on the body and 8 on the tail; also 23 rows of scales. Günther (loc. cit., p. 171) and Boulenger (loc. cit., p. 15) both agree that there are twenty-two rows around the body. This is also the condition in the specimens under examination. The species was well figured by Jan (Icon. gen., 1860, p. 7 ; 1.1 , pl. 5 and 6 , fig. 9); he speaks of it thus, "Typhlops lineatus Reinw. Java. Musee de Leyde."

This form is known from Penang Island and other localities in the lower part of the Malay Peninsula, Sumatra, and Java. I should add that it was not taken by Messrs. Annandale and Robinson during their explorations of Perak 
and the Siamese Malay states. It is, so far as I know, confined to the vicinity of Singapore, where Cantor took it, and Malacea, whence there are specimens in the British museum. For a long time it was known only from Java, but Dumeril and Bibron (loc. cit.) record it as common in Java and equally so in Sumatra. Gray (Cat. lizards Brit. mus., 1845, p. 134) records specimens from India presented by General Hardwicke. In 1893, however, Boulenger (loc. cit., p. 15) records the only example taken by Hardwicke as from Singapore, and also questions the correctness of locality of the Hong Kong specimen, which is probably the same as the one mentioned by Günther (loc. cit., p. 171). In 1896 Werner (Verh. Zool. bot. ges. Wien, 46, p. 13) describes "Typhlops lineatus Boie typ. und var. sumatranus n." This is said to differ from the typical form in having 24 rows of scales around the body and a U-shaped mouth, the typical form having 22 rows of scales and a more $\mathrm{V}$-shaped mouth. The latter character is one which varies greatly in Javan examples; for one of a series of four taken at Buitenzorg in April, 1907, has a mouth with almost parallel sides. The number of rows of scales seems to vary little in these forms, and probably constitutes a valid basis of separation. Dr. Werner ends by suggesting that perhaps this is entitled to be considered a new species, but it seems more probable that extensive collections will show that it can not even be distinguished as a geographical race. There were six other typical examples in the Bryant collection from Buitenzorg, Java.

Typhlops braminus ( (DADDIN).

DAUdin, Hist. nat. rept., 1803, 7, p. 279 (based on Russell's Account of Indian serpents, 1796, 1, p. 48-49, pl. 43). Stejneger, Bull. 58, U. S. nat. mus., 1907, p. 260-262, figs. 232-235.

Type locality:- Vizagapatam, Madras presidency, India.

Color brown, in varying shades; often each scale is dark at the apex and paler at the base. This gives the specimens a minutely speckled appearance. The snout and tip of tail are almost invariably whitish, and frequently also the region about the vent. In those individuals which are about to shed the skin the color is steely gray.

This species is found in a number of situations, most frequently under ground in soft leaf-mould; often under rocks or rotten logs, and under the bark of decaying trees. During January, 1907, two specimens were taken in Buitenzorg, Java, about seven feet from the ground, living in small accumulations of decaying vegetable matter between the base of the leaf of a palm tree and the trunk. The tree was well covered with masses of epiphytic vegetation, and the creatures must have crept up through this to reach the position in which they were taken. 
This species has a very remarkable distribution through the tropical regions of the Old World. It has been previously recorded from the following localities: - South Africa, Madagascar, Arabia, India, the Maldive and Laccadive Islands, Ceylon, Burma, Siam, Straits Settlements, Java, Borneo, Flores, Celebes, Ke and Aru Islands, Moluccas, Philippines, Formosa, Hong Kong, Okinawa Island, Miyakoshima, Yaeyama Island, Riu Kiu Archipelago. In the collections at hand, the following localities are represented, some of which extend the known range considerably. Thus the creature seems generally distributed through the Moluccas and also occurs in Papua.

Manokwari (Doreh), Dutch Papua

Patani, Halmahera I., Moluccas

Ternate I., Moluceas

Wahaai, Ceram I., Moluccas

Buitenzorg, Java

Johore State, Malay Peninsula

Saigon, French Cochin China
2 examples

1 example

1 example

2 examples

14 examples

1 example

1 example

The Bryant collection contains eleven other examples from Buitenzorg.

The following are in the collection of the Museum:-
Madras, India,
M. C. Z., 3,913, 3,914
16 examples
Madras, India
M. C. Z., 5,229 (= T. pammaces)
2 examples
Amballa, India
M. C. Z., 4,270
1 example

Plains 70 miles s. w. of Am-
balla, India,
M. C. Z., 3,750, 5,393
8 examples
M. C. Z., 4,780
1 example

The Plains, India,

Gadow (Amphibia and reptiles, 1901, p. 594) offers the following suggestion regarding this family of snakes. "The Typhlopidae*** are undoubtedly the last living descendants of formerly cosmopolitan, rather archaic, snakes which in adaptation to their burrowing life *** have undergone degradation."

It seems probable, certainly possible, that from this simple form (viz. T. braminus) various local races of full specific distinction have arisen. This species may have spread abroad whilst still there was land connection between the Indo-Malayan Islands and Papuasia. The distribution over the western portion of its range is also suggestive that at perhaps the same time a land-bridge connected Somaliland with Arabia. It is not necessary to assume that these land connections were coexisting,- they probably were not. Is it not also possible that in the last-mentioned connection was included the island of Socotra, 
on which occurs a pallid form varying from $T$. braminus in the following characters: - a wide rostral, a preocular broader than nasal or ocular, and 24 rows of scales around the body. There are many points of close similarity in proportions and squamation between these two forms; the only really noteworthy deviation of $T$. socotranus Blgr. from $T$. braminus being the addition of four rows of scales around the body.

Günther in his article on snakes in the Encyclopaedia Britannica, 1881, p. 190, says: "Snakes are the most stationary of all vertebrates; as long as a locality affords them a sufficiency of food and shelter to which they can readily retreat, they have no inducement to change it. Their dispersal therefore must have been extremely slow and gradual." Again on p. 194 he remarks in direct allusion to the forms under discussion: "Some of the small species have a wide range, having been probably transported by accident on floating objects to distant countries." It seems hardly credible that so small and delicate an organism as $T$. braminus would live under the peculiar conditions to which travel on some "floating object" would subject it; yet it is possibly sometimes carried about with bulbs and roots transported by man. The oft-quoted story of a boa floating two hundred miles from the coast of South America to the Island of St. Vincent, twisted round the trunk of a "cedar tree," has little bearing on the possible dispersal of a Typhlops. South American rivers more than any others are prone to float great matted masses of vegetation to sea, and this occurs quite frequently during the heavy rains. This, however, could hardly ever occur in the case of the greater Indian rivers, for instance; for their courses now, at any rate, lie largely through even plains, perhaps deforested by man for cultivation,- but also largely through sandy wastes. The Irrawaddy does frequently carry down considerable masses of vegetation, but these are not buoyant, and are wave-beaten and saturated with sea-water as soon as they emerge from the delta into the Bay of Bengal. Flotsam carries with it but few terrestrial animals compared to what was once supposed.

Possibly this archaic form, or ancestors of this form, followed some such route of dispersal as Osborn has figured for the elephants ( $c f$. Century mag., 79, p. 829, map). That this form itself dispersed and not its ancestors, seems likely from the fact that no definitive variation occurs within the species itself.

During a visit to Calcutta it was a matter of great interest to learn of the newly discovered T. braminus arenicola Annandale (Mem. Asiat. soc. Bengal, 1, p. 192). This is a peculiar, almost pigmentless, form from "the desert tract of Southern India" in the district of Madura. Dr. Annandale describes two 
new species (Typhlops limbrickii and T. psammophilus), pallid forms also, from this region; and also remarks on the pale color of various desert species in comparison with their relatives. We can conceive that, were this area as isolated as is the island of Socotra, the local race of $T$. braminus would be differentiated, as is $T$. socotranus. In this area of Ramanad we must allow for a more or less constant influx of typical individuals from outside the desert, and this of course reduces the rate of change. Dr. Annandale adds some interesting notes on the habits of $T$. braminus. A living specimen which he kept in an insect cage ate the excerta of caterpillars, and he adds that this very individual was taken from a stick of sugarcane at a considerable height from the ground, where it was living in the tunnel made by some boring caterpillar.

\section{Typhlops polygrammicus ScHLEGEL}

Schleger, Abbild. Amphib., 1839, dec. 2, p. 40, pl. 32, fig. 35-38. Bodlenger, Cat. snakes Brit. mus., 1893,1 , p. 34-35.

Type locality: - Timor.

This species, which has the interesting distribution of Australia and Timor, is represented here by a single example taken in Portuguese Timor, and obtained in exchange from the American museum of natural history.

\section{Typhlops flaviventer Peters}

Peters, Mon. Berl. akad., 1864, p. 271. Boulenger, Cat. snakes Brit. mus., 1893, 1, p. 25.

Type locality: - Ternate Island, Moluccas.

This species was taken but once during about a week of collecting in Ternate, March, 1907. It is very similar in habits to $T$. braminus, but appears more active when disturbed. In life the upper surface is blue-black with iridescence, and the lower surface is chrome-yellow. The edge of the darker color appears sharply serrate, due to the corners of the first row of yellow scales being visible between the corners of the scales of the lowest dark row. The lighter color becomes somewhat diffuse over the upper surface of the head and the tip of the tail. In life the body is strongly depressed, and the creature usually rests rather tightly coiled.

This species is known only from this group of islands: -

Ternate, where von Martens took the type, and where Bruijn took the series reported on by Peters and Doria.

Batjan, one specimen taken by Beccari, the famous companion of d'Albertis in exploration of the Dutch East Indies. 
Halmahera, collection of W. Kükenthal (Boettger, Zool. anz., 1895, 18, p. 129)

Peters and Doria (Ann. Mus. civ. Genova, 1878, 13, p. 384) write the following on the history of this species:- "Questa specie fu descritta da Peters sopra un unico esemplare raccolto a Ternate dal dott. von Martens. Appunto da questa localita il sig. Bruijn ce ne ha inviato una bella serie d'individui e cio ci fu credere che esse vi debba essere piuttosto abbondante. Il Beccari poi ce ne fece avere un esemplare raccolto a Bacian."

The term Molucca Islands, as used for the habitat of this form, is used in the old strict term. Formerly only the islands whence came cloves and nutmegs, - viz. that small chain on the western coast of the large island of Halmahera,were known by this name. Now the term is used to designate the Dutch Residency, which embraces all the islands from Halmahera and Morotai on or north of the equator, to the distant groups of the Ke, Aru, Tenimbar or Timor-Laut, and Sermata Islands. These lie far to the south, and the extreme southwestern islands meet the chains of the Lesser Sunda Islands.

It is probable that this species will be taken on Tidor and the islets between it and Batjan, unless exterminated by the widespread and rather constant or frequent volcanic activity.

Python reticulatus (SchNeIDER).

SChNeider, Hist. Amphib., 1801, 2, p. 264. Botlenger, Cat. snakes Brit. mus., 1893, 1, p. 85-86.

Type locality:- not given.

This Python, which apparently grows larger than any other, is common throughout its extensive range. It is especially abundant in western Java. Everywhere it is essentially a deep forest species, wandering occasionally, however, into cultivated areas.

The geographical distribution of this and other members of the genus is of great interest. $P$. reticulatus is now known from the following islands, as well as from Burma, and the Malay and Indo-Chinese Peninsulas:- Java (M. C. Z.); Sumatra (Werner, Verh. Zool. bot. ges. Wien, 1896, 46, p. 13); Borneo (Blgr., loc. cit.); Philippines (Blgr., loc. cit.); Celebes (Peters \& Doria, Ann. Mus. civ. Genova, 1878, 13, p. 399); Ceram (M. C. Z.); Ambon, Ternate, and Halmahera (Peters \& Doria, loc. cit., and M. C. Z.); Timor-Laut (Blgr., loc. cit.); and more recently it has been taken on Great Natuna Island (Blgr., loc. cit., 1896, 3, p. 592). Six Javan examples from Buitenzorg and Depok, five from the Bryant collection, have an average scale-formula of $72 \frac{298}{102}$. 
Python bivittatus Schlegel.

Schleger, Essai phys. Serp. 1837, 3, p. 403, pl. 15, figs. 1-2. Werner, Zool. jahrb. Syst., 1909, 28, 3 , p. 273.

Type locality:- not mentioned.

The distribution of this form in the Indonesian area was long considered limited to Java and Celebes. For a long time it was not definitely recorded from Sumatra. While this island is by no means completely known herpetologically, it is strange that so conspicuous a form, if it existed there, should have gone so long undiscovered. It is, however, rare in Java compared to P. reticulatus, and possibly has been taken in Sumatra by travellers who mistook it for this more common form. Werner (Zool. garten, 1899, 40, p. 24) has named a race which is distinguished by its dark, rich coloration,- viz. P. m. sondaica. This was based on a living specimen in Hagenbeck's possession which was said to be from Sumatra. Javan examples seem to merit this racial name, and until other Sumatran specimens are found, we may consider it applicable to Javan examples only.

\section{Chondropython viridis (SCHLEGEL).}

Schlegel, Dierentuin Rept., 1872, p. 54. Boulenger, Cat. snakes Brit. mus., 1893, 1, p. 90-91.

Type locality:- Aru Islands.

Color in life brilliant green with an irregular series of creamy yellow spots scattered along the whole dorsal region of the body and tail. Each of these spots covers a single scale. The ventral surface is chrome-yellow. Boulenger (loc. cit.) notes that the color may also be "brick red with bluish, black-edged spots"; this seems to be a rare coloration. The young apparently also show dichromatism; Boulenger writes, "young pinkish or yellowish, with purplish or reddish-brown markings; lower parts yellowish white." Boettger, however, has figured a small specimen from southeastern New Guinea which has the typical coloration of the adult first described ( $c f$. O. Boettger in Semon's Reise, 5, 1, p. 120, taf. 5, fig. 3). Peters and Doria (Ann. Mus. civ. Genova, 1878, 13, p. 403-404) have examined a considerable series of examples of this Python, and do not speak of any but the typical coloration:- viz. green spotted with yellow. The scale formula runs 51-61, rows; 227-241, ventrals; 75-109, subcaudals. In habits this species is a rather slow-moving, inoffensive, nocturnal creature. 'It is much sought after by the Papuans as an article of food.

This beautiful form, which, with the genera Aspidites and Calabaria, seems to approach the boas in that they lack premaxillary teeth, is one of the generic types which have been evolved from some widely spread generalized pythonine 
forms, each in a comparatively circumscribed area. Besides occurring in the Aru Islands, whence the type came, the species occurs on the mainland of Papua, and on the islands of Geelvink Bay. Most specimens have come from the Arfak district, Dutch Papua; and in southern Papua we first hear of it in Boettger's (loc. cit.) report on Semon's collection. Peters and Doria (loc. cit.) record it also from the Dutch Papuan mainland, and also from Ansoes (Ansus), Jobi (Japen or Jappen) Island; and from Kordo (Korido) on Misori (Wiak or Biak) Island, one of the Schouten group. These last records are under the synonymous name $C$. azureus Mayer.

Enygrus asper (GÜNTHER).

Günther, Proc. Zool. soc. London, 1877, p. 132, pl. 21. Boulenger, Cat. snakes Brit. mus., 1893, 1, p. 109.

Type locality:- Duke of York Island, near New Ireland.

A fine specimen of this striking snake from New Britain is M. C. Z. 6,282. This species is now known from a great part of Papua and various islands of the so-called Bismarck Archipelago.

Enygrus bibronii HOMBR. ET JACQ.

Schneider, Hist. Amphib., 1801, 2, p. 261. Boulenger, Cat. snakes Brit. mus., 1893, 1, p. 107-109.

Type locality:- unknown.

The colors of this form are exceedingly variable, and the color-phases seem to have no relation to its geographical range. As regards its habits, it is essentially a tree-dwelling form. Sluggish and inoffensive when handled, its actions call to mind those of living examples of Kropidophis or Eryx. If disturbed after being placed on the ground, it rolls itself up into a tight ball, remaining thus for some time. When left alone, however, it slowly pushes out its head, gradually uncoils, and moves off into the brush. While visiting Djamna Island off Dutch Papua several examples were observed at rest, during daytime. These were all tightly coiled about small twigs springing directly from the trunk of a goodsized tree, the snake resting against the main trunk. With the tree-boas of the West Indies it is more common to find them resting loosely coiled at the crotch formed by several large limbs.

The early history of this species is of some interest. It was known as early as 1735, when Seba figured it. Then Schneider described it in 1801. Although he had examined eight specimens, he knew whence none came. Daudin (Hist. nat. rept., 5, p. 222) in 1803 again described it, but followed Schneider, as there were no specimens in Paris. Schneider discussed it again in 1821 (Denkschr. Akad. wiss. München, 7, p. 118), noting that Merrem (Ann. Wetten. ges., 1810, 
2, p. 60 , pl. 9) has also had specimens with no locality. In 1837 , however, Schlegel (Essai phys. Serp., 2, p. 397, pl. 14, fig. 12-13) tells us that he knows of its occurrence in Ambon, Saparua, and the west coast of Papua. The latter locality was just beginning to be visited by the Dutch. Saparua is rather seldom visited to this day, though for a while of considerable importance as a cloveproducing locality; nevertheless it was decidedly secondary to Ambon in commercial importance. As it was from Ambon that so many of the early collections of natural history objects were sent to Holland, it seems most probable that the types came from there.

Gray (Griffith's Animal kingdom, 1831, 9, p. 97) states that the species comes from India; but this statement is untrustworthy.

As we know it now, this species has a wide range over Papuasia. It has been recorded from the following, and doubtless other, localities:-Dutch Papua, Mansinam, Doreh, Sorong, Andai, Ansus, Jobi Island; Korido, Wiak Island; also Batanta, Salawati, and Mysol Islands; it is also found about Huon Gulf in southeastern Papua. Among the Moluceas it has been taken in Ambon, Ceram, Timor-Laut, Ternate, and Halmahera. Among the Solomon groups on the following islands:-Faro, Shortland, Treasury, Florida, San Cristoval, Ugi, and Santa Anna. It occurs on Normenby and Rossel Islands among the Louisiades, and also in the Pelew group, this latter being the type locality for the synonym E. superciliaris (Günther, Ann. mag. nat. hist., 1863, ser. 3,7 , p. 360, pl. 6, fig. 2).

The specimens which have been examined here are from Ceram Island and Djamna Island in Papua; and were taken during 1906-1907. Two specimens from the latter very small islet are extreme examples of the color-phases which Boulenger has designated $\mathrm{A}$ and $\mathrm{C}$. The squamation of all these specimens is included in the range of variation which Boulenger has shown to exist. It may be added that Méhely (Termes. füzetek, 1895, 18, p. 132) notes that a specimen from Astrolabe Bay falls under Boulenger's group B. Boettger (Berl. Offenb. ver., 1892, p. 152) has also studied specimens from southeastern Papua.

Cylindrophis rufus (LAURENTI).

Latrenti, Syn. Rept., 1768, p. 71. "Anguis ruffa" (sic). Boulenger, Cat. snakes Brit. mus., 1893, 1, p. $135-136$.

Type locality: - "Surinam"; in the Museum Gronovianum.

No geographical races seem to occur in the rather wide range of this species. Specimens from Java may have their scales in either 19 or 21 rows, and the range of their ventral and subcaudal scale-counts is the same as that of specimens from 
the mainland. This species is doubtless common, though difficult to find, in the vicinity of Buitenzorg. It is usually found burrowing in leaf-mould, or under the loose bark of a decaying forest tree. The brilliant red of the under surface of the tail is lost very soon after preservation in spirits. This form occurs over southeastern Asia, and on Sumatra, Java, Borneo, and Celebes. Among a few purchased snakes, which were said to have come from Ternate, are several specimens with no unusual features as regards color or squamation.

The curious habit which this form, as well as Doliophis intestinalis, has of exposing the red under surface of the tail, has been well described and figured by Flower (Proc. Zool. soc. London, 1899, p. 656-657, pl. 37). I had excellent opportunity to verify these observations, with which my own agree. It should be added, however, that the Javanese have not the fear of either of these serpents which seems to be held by the Peninsula Malays. (Boulenger, Fasc. Malay. Zool., 1903, 1, p. 169-170. Annandale's field notes).

\section{Xenopeltis unicolor ReINwardT.}

Reinwardt in Boie, Isis, 1827, p. 564. Bovlenger, Cat. snakes Brit. mus., 1893, 1, p. 168-169.

Type locality: - Java.

Bryant got one example at Buitenzorg. It is typical in every way. Schlegel (Essai phys. Serp., 1837, 2, p. 20) says: "Le Xenopeltis est un des serpens les plus rares de l'ile de Java, ou le professeur Reinwardt l'a decouvert le premier; il a ete depuis retrouve par nos voyageurs a Sumatra et a ete egalement envoye de Celebe au Musee de Paris." Rare it certainly is, for up to 1907 the Buitenzorg museum had no specimens, and I was quite unable to find the species myself.

\section{Chersydrus granulatus (SCHNEIDER).}

Schneider, Hist. Amphib., 1799, 1, p. 243. Boulenger, Cat. snakes Brit. mus., 1893, 1, p. 174.

Type locality: - unknown.

This form is barely separable generically from its doubtless very near ally, Acrochordus javanicus Hornstedt. Except for the greater compression of body and tail and the elevation of a few series of ventral scales to form a median ventral fold, these forms are extremely similar in both internal and external morphology. It seems probable that a critical review of the five known genera of Acrochordinae would reduce Chersydrus to subgeneric rank. This can not be undertaken now on account of lack of material. All of the other genera, except Acrochordus and Chersydrus are very rare in collections. C. granulatus is generally common in brackish or salt-water. At Makassar, Celebes, it may be found at almost any time crawling slowly on the filthy floor of the "passer 
ikan" (fish market), beneath the platforms on which the Buginese fishermen expose their catch for sale. They probably drop from the nets which the fishermen bring to the market to mend and dry during the latter part of the day, after their catch has either been sold, or has spoiled from the heat. They do not live more than a few hours out of water, and are always extremely inactive and offer no resistance when handled. The fishermen at Makassar are not at all afraid of them; but in Batavia they are considered deadly by the Malay fishermen. Young specimens have the body more compressed and are of more brilliant color than adults. In specimens about one foot in length the depth of body is nearly 2.5 times the thickness. Adults are barely compressed at all. It has been impossible to examine anything but adult specimens of Acrochordus javanicus, and the condition seen in the young of this species would be of the greatest interest. In $C$. granulatus the young are boldly striped with vertical bars of black and light buff. In many cases the light bands do not cross the dorsal region. In adults the black becomes a dull brown, and the light regions of the young show only a faint irregu'ar triangle of dirty lighter brown on the sides.

This species has a wide distribution along the coasts of India and southeastern Asia, and throughout the Indonesian area to and including New Guinea. It seems generally distributed.

\section{Sibynophis geminatus (BOIE). ${ }^{1}$}

Boie, Isis, 1826, p. 211. Boulenger, Cat. snakes Brit. mus., 1893, 1, p. 185.

Type locality: - Java (fide Schlegel).

Bryant had two individuals, both from Buitenzorg. This is another very rare snake in western Java. These individuals were typical in every way, and their scale-counts fell well within the limits set by Boulenger.

Natrix mairii (Gray).

Gray, Grey's Journals Australia, 1841, 2, p. 442. Boulenger, Ann. Mus. civ. Genova, 1898, 38, p. 703.

Type locality: - New Holland.

Boulenger (loc. cit.) in reporting on Loria's collection from British New Guinea takes occasion to point out that this valid species, along with several others, had been long wrongly buried in the synonymy of $N$. picturata (Schl.).

Two examples from Fak Fak, Dutch New Guinea, collected by A. E. Pratt, agree well with this species as now restricted.

${ }^{1}$ For use of the name $c f$. Stejneger, Proc. U. S. nat. mus., 1910, 38, p. 102. 
Natrix trianguligera (BoIE).

BoIE, Isis, 1827, p. 535. Boutenger, Cat. snakes Brit. mus., 1893, 1, p. 224-225.

Type locality: - West Java (fide Schlegel).

Serpents of this species, together with $N$. submiata and $N$. vittata, are the common water-snakes of the rice-fields of Java. The species under consideration is probably rather less common than the other two, which are both about equally abundant. Before me are ten specimens from Buitenzorg, March-April, 1907, and five from Buitenzorg and one from Depok in the Bryant collection. About half of all the adults of these common species of Natrix have their tails bitten off, evidently the work of turtles. $N$. trianguligera shows in its coloration three distinct growth stages. (1) In the freshly hatched young the back is olivebrown, faintly barred and mottled; the throat and anterior half of the belly are dull yellow, with a coppery tinge; this color extends up between the lateral triangular markings of the olive; the tail is encircled by many complete blackbrown rings; the ground color of the ventral surface of the tail and the posterior half of the belly is ivory-white. (2) In half-grown examples we find a red blotch situated between the dark lateral markings on the anterior part of the body, while on the posterior part the markings become indistinct. (3) In fully adult specimens the whole dorsal and lateral surfaces become mottled olive, the lateral triangular spots show as faint darker areas. The whole lower surface of body and tail becomes white. The rings under the tail show only as the faintest dark lines.

All of the specimens show great uniformity in the number of ventral scales. The range is $137-143$, and the average 140 ; on the other hand the number of subcaudals may vary greatly; the range $67-99$ exceeds by five that given by Boulenger for specimens from widely separated localities. The single specimen from Java in the British museum had scales 139-69. Speaking generally from Boulenger's figures, the Bornean specimens seem to average lower and Sumatran higher in scale numbers than the Javan. But nothing conclusive can be said without far larger numbers.

This snake has a wide range, from Burma and Malaya to Sumatra, Nias, Java, and Borneo.

Natrix sancti-johannis (BotLENGER).

Boulenger, Fauna Brit. India. Rept. Batr., 1890, p. 350; Cat. snåkes Brit. mus., 1893, 1, p. 230, pl. 15, fig. 1.

A single very large specimen of this species from a pond near Lucknow, United Provinces, India, November, 1907. This form, judging from this and 
other examples apparently of this species from the Koolloo Valley in the collection of the Museum, while evidently nearly related to Natrix piscator, seems too distinct to be relegated to subspecific rank unless it can be shown to intergrade with this species. The smovth, or nearly smooth, dorsal scales, and the smooth rows near the ventrals seem constant characters. The fourth labial only enters the orbit generally but according to Boulenger it is not always alone in doing so.

Natrix piscator (SCHNEIDER).

Schneider, Hist. Amphib., 1799, 1, p. 247. Bodlenger, Cat. snakes Brit. mus., 1893, 1, p. 230-232. Stejneger, Bull. 58, U. S. nat. mus., 1907, p. 288-291.

Type locality: - India.

Six specimens of this species were taken at Buitenzorg, Java, and all belong to var. C of Boulenger; as do also five from Daroe, Bantam, and fifteen from Depok, in the Bryant collection. Two from Java, and one from Borneo, were in the British museum. There were three other specimens (vars. A and B) in the same collection, also said to be from Java. These Javanese specimens were all taken by Horsfeld. Now, excepting this lot, which may be from some other locality, it seems probable that all Indonesian examples belong to this race. All the examples in the Buitenzorg museum did, if I remember correctly, and all that Werner reported from Sumatra (Verh. Zool. bot. ges. Wien, 1896, 46, p. 14). It is, I think, quite certain that the race is confined to this area. We may then designate it correctly as $N$. p. melanozosta (Boie).

In Java it is rare as compared to the Indian form, which seems to occur widely spread ( $c f$. list of localities for British museum examples, Boulenger, loc. cit.). In the M. C. Z. there are many examples from the Koolloo Valley, from Madras, and from Calcutta. Dr. Stejneger writes me that a specimen which I sent for his examination is indistinguishable from a cotype of Hallowell's, $N$. flavipunctata; the example came from Ting-an, Hainan. Boulenger and Stejneger agree that this species from Canton is synonymous with $N$. piscator.

The range of this snake extends from India to the Malay Peninsula, Siam, south and Cochin China; also to Java, Sumatra, and Borneo.

The six Buitenzorg specimens mentioned above have their ventral scalation as follows:- V. 134, C. 80 ; V. 145, C. 67 ; V. 140 , C. ?; V. 147 , C. $72 ;$ V. 149 , C. 68; the five Daru, Bantam, examples:-V. 139, C. 79; V. 137, C.?; V. 143, C. ?; V. 137 , C. 89 ; V. 139 , C. 72 ; and the Depok fifteen: - V. 128, C. 77 ; V. 142 , C. 67 ; V. 143 , C. $69 ;$ V. 132 , C. $72 ;$ V. 145 , C. 66 ; V. 141, C. $72 ;$ V. 141 , C.?; V. 141 , C. 67 ; V. 145 , C. 73 ; V. 140 , C. 52 ; V. 144 , C.?; V. 147, C.?; V. 139 , C. 70 ; V. 134 , C. 78 . The lepidosis does not afford any basis for the 
racial separation which has been made on the ground of the great distinctness of color. The body of the largest specimen is $21^{\prime \prime}$ long, and the tail $8^{\prime \prime}$.

Flower (Proc. Zool. soc., London, 1896, p. 660) gives some important notes which tend to show that var. B is also a local race which should be recognized by a subspecific name.

\section{Natrix stolata (Linne).}

Linnt, Syst. nat., ed. 10, 1758, 1, p. 219. StEJNEGER, Bull. 58, U. S. nat. mus., 1907, p. 280-283.

Type locality: — "America."

A specimen of this species was taken near Lucknow, India, November, 1907, in the act of swallowing a frog (Rana tigerina). In the Museum collections a large number are preserved from various localities in India, especially from near Umballa. The Rev. M. M. Carlton sent large collections of Indian reptiles to this institution from that locality. Boettger (Ber. Senck. nat. ges., 1894,p. 132) records seven specimens from Hainan. These certainly average higher in number of scales than Indian or even Formosan specimens. Thus, for eight examples from Hainan the average is $\mathbf{1 5 0}$ for ventrals and 79 for subcaudals; range, V. 148-152, C. 76-81. According to Boulenger's statistics (Cat. snakes Brit. mus., 1893, 1, p. 254) Indian specimens range as follows:- V. 120-158, C. 50-87. The average, however, is far lower than for the Hainan series. Stejneger's data for Formosan specimens (loc. cit.), thirteen in number, show no evidence of any peculiar local conditions; these range: - V. 142-150, C. 65-81. Curiously specimens from Nepaul, the Khasi Hills, and Himalayas, average a little higher than do the Hainan specimens, which come next in average number of scales; then follow Formosan and Chinese, and then specimens from Lower India and Ceylon.

Known from India and Ceylon to the Philippines and Formosa. It is not certainly known from the Dutch East Indies. There is, however, in the British museum a specimen said to be from Borneo. Boulenger doubts the accuracy of this record.

From its wide continuous range and general prevalence, this species is probably one of those whose migration has been comparatively recent; and it is probably still in process of actively increasing its range.

Natris vittata (LINNE).

Linne, Syst. nat., ed. 10, 1758, 1, p. 219 . Boulenger, Cat. snakes Brit. mus., 1893, 1, p. 255.

Type locality:- "America."

Fifteen specimens from Buitenzorg; and, in the Bryant series, ten from Buitenzorg, eight from Depok, and six from Daroe, Bantam. The range of 
counts for the ventral scales is slightly increased by this series over what Boulenger gave, viz. V. 138-155; C. 47-85. The anal is divided in all examples except one. The coloration of this species shows no marked variation between young and adult.

This water-snake is locally abundant in the "sawas" or rice-fields. It feeds on frogs and small fish. My records do not show that it was seen at altitudes of more than 1,000 feet.

This form is known from the Malay Peninsula, Java, and Celebes.

Natrix subminiata (SCHLEGEL)

Schlegei, Essai phys. Serp., 1837, 2, p. 313. Bodlenger, Cat. snakes Brit. mus., 1893, 1, p. 256-257.

Type locality:- Java.

A comparison of the scale-counts which Boulenger has given for specimens from a number of widely separated localities with the conditions in a series of thirty-six specimens obtained about Buitenzorg, Java, during January, March, and April, 1907, and eighteen from the same place taken by Bryant, points strongly to the existence of geographic races within the species. Thus, specimens from the type locality, have 143.8 as an average number of ventral scales, and 70.3 for subcaudals.s. Ventrals range from 136 to 147 , and subcaudals from 64 to 74 , in the Buitenzorg material mentioned above; U. S. nat. mus. 5425 (141-73); several specimens mentioned by Boulenger (loc. cit.); four recorded by Boettger (Semon's Reise. Zool., 1899, 5, 1, p. 123); and four in this Museum also from Java,- a total of sixty-eight Javan examples.

This species in its distribution recalls that of Agkistrodon rhodostoma and Geoclemys trijuga, since it is unknown in both Sumatra and Borneo.

We pass on now to specimens which have been recorded by Boulenger from Tenasserim, Siam, Lao Mountains, and Camboja: seven specimens have as an average number 150.4 ventrals and 77.3 subcaudals. The range of ventrals is 144-157; and that of subcaudals, 73-82. Flower, however, has recorded (Proc. Zool. soc. London, 1899, p. 662-663) six specimens from Bangkok with ventrals averaging 146 , and subcaudals 71 , the ranges of ventrals being 138-151, and subcaudals 70-73. These combined give an average, viz. 148.2 and 74, higher than that of the Javan specimens, although the range is not widely different.

Specimens from Hong Kong recorded by Boulenger average V. 138, C. 71.3; range V. 132-143, C. 68-76; while others again from India and the Shan States average V. 165.4 , C. 79.7 ; range V. 163-166, C. 75-86. The specimen in the British museum taken by the Challenger at Ternate has V. 147, C. 70. Finally, 
we know from Celebes a specimen described by Günther (Proc. Zool. soc. London, 1873, p. 170) as Tropidonotus manadensis, which had an unusual formula, V. 139, C. 76. This is certainly not specifically distinct from N. subminiata, but more material might establish a race in Celebes, as also others in Malaya and Siam, as well as China and India. The limited material now available makes the naming of these forms at present unwise.

One Buitenzorg specimen combines unusual variations, - the presence of two preoculars and seven supralabials, of which the third and fourth only enter the orbit.

Since writing the above statement I have received from the Indian museum, thanks to Dr. Nelson Annandale, two specimens of this species; one from Samagooting, Assam, with a count of V.172, C. 83; and another from the Northern Shan States of Burma, with a count of V. 166, C. 81. The latter snake is twice as large as the largest Javan individual I have seen.

Natrix chrysarga (Schlegel).

Schleger, Essai phys. Serp., 1837, 2, p. 312, pl. 12, fig. 6-7. Bodlenger, Cat. snakes Brit. mus., 1893, 1, p. 258-259.

Type locality:- West Java.

The Bryant collection contains three examples of this water-snake:- one from Gunung Bunder, Mt. Salak, Java, with V. 166, C. 60; and two from Tjibodas, Java, V. 154, 155; C. ?, 77. In all there are nineteen rows of scales. This narrow range for these three specimens comes far within that given by Boulenger.

Natrix maculata (EDELiNG).

Edeling, Nederl. Tijds. Dierk., 1864, 2, p. 203. Bodlenger, Cat. snakes Brit. mus., 1893, 1, p. 260.

Type locality:- Bandjermasin, Borneo.

A specimen, M. C. Z. 7307 (T. Barbour), came from northern Sumatra. It agrees well with Boulenger's description so far as squamation is concerned, but differs in coloration. There are black blotches on each side of the neck, and but two dorsal rows of dark spots, generally alternating in position. There is a black spot at each end of every ventral shield.

Brachyorrhus albus (LINNÉ).

Linne, Syst. nat., ed. 10, 1758, 1, p. 218. Boulenger, Cat. snakes Brit. mus., 1893, 1, p. 305-306.

Type locality:- " Habitat in Indiis."

Four specimens of this variable form are in hand,- three from Ternate, and one from Ambon. They were all taken by Malay helpers; and it is, unfortunately, impossible to offer any notes on either habits or habitat. 
In the example from Ambon the preocular is present on both sides; in one of those from Ternate it is absent on both sides, being fused with prefrontals; while in another it is present on one side and absent on the other. The color when freshly taken was a beautiful rich brown with plumbeous iridescence, fading on the sides and becoming a rich yellowish cream color on the ventral surface. The Ambon and one of the Ternate specimens have the characteristic dusky midventral stripe under the tail. It is lacking in another specimen from Ternate. A young one is characteristically distinct in coloration.

This snake is recorded from Java, where according to Schlegel (Essai phys. Serp., 1837, 2, p. 33) it is very rare. This is a definite statement, certainly, but undoubtedly incorrect. The other localities are Timor, Ambon, Halmahera, Ternate, New Guinea, and Jappen (or Jobi) Island. It is apparently nowhere common.

There is no available material by which to determine whether B. jobiensis (Meyer) is a valid species or not. According to Boulenger, the fusing of the internasals is not a constant character. Peters and Doria permitted it to stand as a distinct species provisionally, or until more material was available. It probably represents a local race at least; this fusion of scales does not apparently occur in specimens from other than the Papuan localities.

Elapoides fuscus Bore.

BoIe, Isis, 1827, p. 579. Boulenger, Cat. snakes Brit. mus., 1893, 1, p. 307.

Type locality: - Java.

This is a species which seems to be confined to the Javan highlands. Two specimens, var. A of Boulenger, were taken in April, 1907, near Sindanglaia, at about 5,000 feet above sea-level; and there is one from Tjibodas, near by, in the Bryant collection. The native collector who brought in the two snakes said that they were found in ponds. There are several such ponds in ancient craters at high levels. The native did not distinguish these creatures from Enhydris; I imagine their habits are similar. Of the six species in the British museum, three, - all those having definite data, - came from Kediri, Java, at 5,000 ft. elevation. This adds weight to my own observation, and to those of Major Ouwens of Buitenzorg, who very frequently spoke of the great dissimilarity of faunae between the Botanical Garden at Buitenzorg and the Mountain Station, near which these snakes were taken.

Known only from Java and Sumatra. 
Lycodon subcinctus BoIE.

Bore, Isis, 1827, p. 551. Boulenger, Cat. snakes Brit. mus., 1893, 1, p. 359-360.

Type locality: - Java (fide Schlegel, Essai phys. Serp., 1837, 2, p. 117).

In the Museum there are three specimens of this species from Batavia; and there is one in the Bryant collection, from Depok, with perfectly smooth dorsals, but otherwise typical. The apparent absence of this species from Buitenzorg or higher altitudes would make it seem almost certain that it is most common in, if not entirely confined to, the coastal lowlands. In each case eight supralabials are present, and there is no preocular; in two the anal is divided, while in the third it is entire.

Range:-Malay Peninsula, Great Sunda Islands (except Celebes), Philippines.

Lycodon striatus (SHAw).

Shaw, Gen. zool., 1802, 3, p. 527. Bodlenger, Cat. snakes Brit. mus., 1893, 1, p. 349-350.

Type locality: - India.

This Museum has specimens of this generally scarce form from various localities in India. It is also known from Transcaspia and Ceylon.

Lycodon aulicus (LINNÉ).

Linnt, Syst. nat., ed. 10, 1758, 1, p. 220. Boulenger, Cat. snakes Brit. mus., 1893, 1, p. 352-354.

Type locality: - "Habitat in America."

This form is one of the most widely distributed of Asiatic reptiles, as well as one of the most variable in coloration. In many parts of India it is extremely abundant, notably in the vicinity of Lucknow, where it was common during November, 1907, in swampy lowlands, especially near ponds and tanks. There are in the collection here specimens from Pondicherry, Madras, Amballa, Bombay, Lucknow, in India; Pegu and Rangoon, in Burma; Ceylon; Singapore; Bangkok, Siam; Java, Philippine Islands, and Bourbon. In the last locality it was undoubtedly introduced, probably very early, as the specimen here is an old one obtained by exchange from Dumeril. There is a specimen from the same locality recorded by Boulenger in the British museum. This species, judging from several stomachs contents, feeds almost exclusively on scincoid lizards. It may be noted that the extent of contact between loreal and internasal varies extremely in individuals. They are always in contact, but frequently only to a slight extent.

Range:- India and Ceylon to Cochin China; through the Malay Archipelago, as far east as Celebes and Timor.

A specimen taken at Buitenzorg, April, 1907, belongs to Boulenger's var. D; 
color, slaty with a diffuse network of white lines. A specimen (M. C. Z., No. $3,055)$, from Batavia, is almost uniform brown with a white collar. Five Bryant specimens from Buitenzorg and one from Depok are also the same in color as var. $\mathrm{D}$ of Boulenger. They may be known as L. aulicus capucinus Boie.

Stegonotus cucullatus (DuM. ET BiBr.).

Dumeril et Bibron, Erpet. gen., 1854, 7, p. 376. Bodlenger, Cat. snakes Brit. mus., 1893, 1, p. 365.

Type locality: - Dorey, Dutch New Guinea.

Two fine examples of this Papuasian species were in a small collection obtained from that excellent zoölogical collector, Mr. A. E. Pratt. He took them at Fak Fak, in western Dutch New Guinea.

Stegonotus modestus (SCHLEget).

Schlegrl, Essai phys. Serp., 1837, 2, p. 119, pl. 4, fig. 16-17. Boulenger, Cat. snakes Brit. mus., 1893,1, p. 366.

Type locality: - Ambon. Schlegel definitely mentions this type locality for the only specimen which he had for description and figuring. He simply mentions passim that the Paris museum had a snake, apparently similar, taken by Lesson and Garnot in the forests of New Guinea near. Dorey Bay. This specimen was the very one which served Dumeril and Bibron for the type of their Lycodon cucullatus.

In the collection made by Pratt at Fak Fak, New Guinea, there were two large examples of this rather widespread species.

Zaocys carinatus (GüNTHER).

Günther, Cat. snakes Brit. mus., 1858, p. 112. Boulenger, Cat. snakes Brit. mus., 1893, 1, p. 377, pl. 27 , fig. 1.

Type locality: - not specified.

It was a great surprise to find two adults of this species from Depok, Java, in the Bryant collection. Both are quite typical, except for the presence of nine supralabials on the left side of the head of one of them. In this case the fifth and sixth supralabials enter the eye, while ordinarily this is done by the fourth and fifth.

Boulenger gave the range for this species as Borneo, Sumatra, and the Malay Peninsula; I have found no previous Javan records for its occurrence. It is evidently very rare, and of local distribution.

Ptyas korros (Schlegel).

Schleget, Essai phys. Serp., 1837, 2, p. 139. StejNeger, Bull. 58, U. S. nat. mus., 1907, p. 348-349.

Type locality: - Java.

This species is abundant about Buitenzorg. Nine examples were taken 
there during March and April, 1907. Bryant also took ten there, one at Daroe Bantam, and five at Depok. All of these fall in with the characters which Stejneger (loc. cit., p. 345) has used in his key. "Scale rows 15; scale rows a head length anterior to vent 11 ; ventrals less than $185 . "$

Known from Asia, from northern India to southern China southward; also from Sumatra and Java.

None of the smaller of these specimens, say from two to two and a half feet long, have any traces of the cross-bands composed of transverse series of pearlshaped spots, which, according to Stejneger, the young are said to possess. The Malay name is Ular Kar-rus.

P. mucosus (Linné) was not observed in Java; nor did Bryant find a specimen in his long collecting.

\section{Xenelaphis hexagonotus (CANTOR).}

Cantor, Cat. Malay. rept, 1847, p. 74. Boulenger, Cat. snakes Brit. mus., II, 1894, p. 8.

Type locality: - "the great Hill of Pinang."

The only Insulindian individual examined is one which Bryant got at Buitenzorg. Its ventral count, 178, is seven less than the lowest number given by Boulenger, while the subcaudals number five less, or 140. This again is one of the rarest of west Javan snakes.

\section{Gonyosoma oxycephala (BoIE).}

BoIe, Isis, 1827, p. 537. Boulenger, Cat. snakes Brit. mus., 1894, 2, p. 56-57.

Type locality:- Java, collection of Reinwardt.

This beautiful serpent is not uncommon about Buitenzorg. Four specimens were caught during March, 1907; and Bryant also took several specimens in or near Buitenzorg and Depok. During the daytime this species seems to spend much of its time tightly coiled up in trees; but if disturbed it will become extremely aggressive, and can move and strike with wonderful rapidity. It is a very quick-tempered snake.

It is evident that the range of this species is either very incompletely known as yet, or else the distribution took place at so remote a period that the form has had time to die out in many areas. It is known from the eastern Himalayas, Tenasserim, Philippines, the lower part of the Malay Peninsula, Borneo, Natuna, and Java. 
Elaphe molanura (Schlegel).

Schlegel, Essai phys. Serp., 1837, 3, p. 141, pl. 5, fig. 11-12. Botlenger, Cat. snakes Brit. mus., 1894, 2, p. 60-61.

Type locality:- probably Java was the locality whence the first specimens came, but Schlegel states that specimens from Sumatra and Celebes were in the Leyden museum at the time of his writing. He states that Reinwardt took two specimens, these were probably his Javan examples.

I found this species rare in Java; a single young specimen only was taken on the mountain slopes above Tjibodas; while Bryant got four at Buitenzorg, two on Mt. Salak at 2,200 feet, and one on Mt. Gede near Tjibodas. It has a median dorsal stripe of brilliant lemon-yellow beginning on the head and running about one third the length of the body. No. 2,197 M. C. Z. is an adult from Java identified by Jan and received from Dumeril.

This species occurs on the mainland in Burma, southern China, and the Malay Peninsula; among the islands it has recently been taken on Sumatra, Nias, Borneo, and Java. The specimens spoken of by Schlegel from Celebes were undoubtedly E. erythrura (Dum. \& Bibr.).

Dendrophis pictus (GMELIN).

Gmelin, Syst. nat., 1769, 1, p. 1116. Bodlenger, Cat. snakes Brit. mus., 1894, 2, p. 78-79.

Type locality:- unknown.

Only seven specimens of this common snake, taken March-April, 1907, at Buitenzorg, were preserved. Bryant, however, saved a large series,-- fourteen from Buitenzorg, three from Depok, and one from Daroe in Bantam. All are typical examples; in every case the eye is smaller in diameter than the distance to the nostril. Two postoculars and a loreal are present in all.

Ranges from Bengal to Cochin China, throughout the Malay Archipelago. The fact that in the British museum there is an example from Mysol would make it seem very probable that the last connection between Papuasia and the Moluccas lay there, as noted in the chapter on geographical distribution.

Dendrophis formosus BoIE.

Bore, Isis, 1827, p. 542. Boulenger, Cat. snakes Brit. mus., 1894, 2, p. 84-85.

Type locality:- Schlegel says, "Le Professeur Reinwardt a fait la découverte de cette espèce à l'île de Java, où elle est assez rare."

Boulenger gives its distribution as "Mountains of the Malay Peninsula, Borneo, Java." Byrant, however, found it sparingly about Buitenzorg, where he took six examples. The elevation of this locality is about 900 feet, while the species is not found in his collections from several Mountain Stations. 
Holarchus octolineatus (SCHNEIDER).

Schnemer, Hist. Amphib., 1801, 2, p. 299. Boulenger, Cat. snakes Brit. mus., 1894, 2, p. 224.

Type locality:- unknown.

This snake is decidedly rare in Java. Only a single specimen was taken during March, 1907, while Bryant got two at Depok. These belong to Boulenger's var. A. These color-phases, A and B, really merit no designation, for they occur in as nearly a haphazard manner as can be imagined. It is very probable that "Simotes meyerlinkii," which Steindachner described from the Sulu Islands, is a valid species; it deserves a subspecifie rank at least. The number of ventrals is low, 158 in Boulenger's specimen from Tawi Tawi, and 156161 according to Steindachner. The color also is distinctive. For $\mathrm{H}$. octolineatus, the lowest number of ventrals is 165 , recorded from Singapore. The average for specimens from many various localities is 176. Javan examples range from V. 175-186, C. 55-58. The Malay name is Ular pi-ter.

The range of this form includes southern India, the Malay Peninsula, Sumatra, Java, and Borneo. H. meyerlinkii (Steind.) was doubtless evolved by isolation from specimens of this species probably derived from Borneo.

Oligodon bitorquatus Bore.

Bore, Isis, 1827, p. 519. Boulenger, Cat. snakes Brit. mus., 1894, 2, p. 237.

Two typical examples seen. Bryant's specimen from Tjibodas, Mt. Gede, 4,500 feet, is the only one with specific locality.

In 1860 Bleeker described Rabdosoma amboinense, which Boulenger placed in the synonymy of this species. I have discussed elsewhere (p. 24) the possibility of Bleeker's type ever having seen Ambon, and I believe that it was simply a Javan example, which got mixed into an Ambon collection. This sort of thing evidently happened to Bleeker with startling frequency.

Liopeltis baliodirus (BoIE).

Boie, Isis, 1827, p. 539. Bodlenger, Cat. snakes Brit. mus., 1894, 2, p. 283.

Type locality:- East Java (fide Schlegel).

Having examined an unfortunately small specimen from Sumatra which the M. C. Z. obtained by exchange with the American museum of natural history, I did not find the hypapophyses, which Cope mentioned as being present throughout the vertebral column. So this species may be considered congeneric with the other members of the genus Liopeltis; the latter name should take the place of Ablabes. This has been pointed out by Stejneger (Bull. 58 U. S. nat. mus., 1907, p. 337-338). If, however, hypapophyses are 
found to be present when adult individuals are carefully examined, then the name Gonglyosoma of Fitzinger becomes available for $L$. baliodirus, generically separated from the species with which it is now associated.

\section{Iiopeltis libertatis BARBOUR.}

Plate 6, fig. 18 and 19.

Barbour, Proc. Biol. soc. Wash., 1910, 23, p. 169-170.

Type locality: - Buitenzorg, Java.

This distinct species is known only from the type; regarding its habits we have no data.

Pseudorhabdium longiceps (CANTOR).

Cantor, Cat. Malay rept., 1847, p. 63, pl. 00, fig. 1. Boulenger, Cat. snakes Brit. mus., 1894, 2, p. 329.

Type locality: - "the great Hill of Pinang."

A single example from Sumatra in collection of Museum of Comparative Zoölogy (T. Barbour).

\section{Calamaria linnei BoIE. ${ }^{1}$}

BoIf, Isis, 1827, p. 539. Boulenger, Cat. snakes Brit. mus., 1894, p. 345-346.

Type locality: - Java.

Of this species, which is the most abundant member of the genus in western Java, seven specimens were taken at Buitenzorg and two at Sindanglaia. Among the examples from the lot first mentioned, four belong to what Boulenger has called var. B; two stand between var. B and $\mathrm{C}$; one is typical of $\mathrm{F}$. Both the specimens from the mountains belong to var. B. Taking these nine examples in the order in which they have been mentioned, their scale-formulae are as follows:-V. 152, C. 9; V. 146, C. 15 ; V. 156, C. 11; V. 157, C. 10 . These counts are for the four of var. B from Buitenzorg. Examples between B and C:-V. 154 , C. 10 ; V. 142 , C. 16 . Example of var. F:-V. 155, C. 9 . Sindanglaia specimens:-V.145, C. 19; and V. 155, C. 11. Bryant had twenty-four from Buitenzorg. These range in count from V. 130 to 161 ; C. 8 to 17 . He had two from Gunung Bunder, which count V. 131-148; C. 16-19. Also, besides this long series of var. B, he had two of var. A, and two of var. F.

\section{Calamaria sumatrana EDELING.}

Edeling, Nat. tijd. Ned. Ind., 1870, 31, p. 379. Bodlenger, Cat. snakes Brit. mus., 1894, 2, p. 339-340.

Type locality: - Redjang, Sumatra.

It is interesting to note that among the snakes of this genus which were

${ }^{1}$ Linné's Coluber calamarius = Oligodon templetonii Gthr. Cf. Anderson, Bihang. Kongl. svensk. vet. akad. Handlingar, 1899, 24, 4, p. 8. 
caught at Sindanglaia, in the Preanger region of Java, there was a single adult example of this rare form. It constitutes an addition to the ophidian fauna of Java, for it was previously known only from Singapore and various localities in Sumatra. Probably this form will prove to be separable into three races. The Singapore specimen, now in the Indian museum at Calcutta, has a small number of ventral scales, V. 129, C. 31. The Sumatran specimens have more:-V. 142-168; C. 13-24. In the single known Javan example there are V. 190, C. 21. In this specimen also the rostral is broader than deep, and the diameter of the eye is less than the distance from the mouth.

Range:- Singapore, Sumatra, west Java.

Calamaria virgulata Bore.

Bore, Isis, 1827, p. 540. Bodlenger, Cat. snakes Brit. mus., 1894, 2, p. 340-341.

Type locality: - not definitely stated, but a citation to the "Erp. de Java," which never appeared, leads me to suppose that the specimens came from Java.

Three specimens of this form, which Boulenger calls var. C, were taken near Sindanglaia, Java, on the slopes of the twin volcanoes Pangerango and Gedeh at altitudes varying from 3,500 to 4,500 feet. Ventrals, 164, 166, 180; subcaudals, $19,25,26$. This species seems to replace to some extent $C$. calamaria, for about Buitenzorg the latter is common, while no specimens of $C$. virgulata were seen. Probably this form is an inhabitant of a life-zone higher than Buitenzorg; I have pointed out that this is also true of other species. The specimens in the British museum which have definite locality records seem to bear out this conclusion. Thus, there are specimens from Fort de Kock in the Padang Highlands, and also from Mt. Singalang in Sumatra. Menado in Celebes lies near highlands where, as they offer the best opportunities for collecting, Dr. Meyer's examples were probably taken. Two out of three of the Javan specimens bear no data. One is from Rarahan, but the altitude of this locality I have not found.

Known from Sumatra, Java, and Celebes.

Calamaria borneensis BleEKER.

Bleeker, Nat. tijd. Ned. Ind., 1860, 21, p. 296. Boulenger, Cat. snakes Brit. mus., 1894, 2, p. 347.

Type locality: - Sintang, Borneo.

A single specimen of this rather rare and apparently dichromatic form, M. C. Z. 5,241. This species is now known from Sarawak, and also from a number of localities in Dutch South Borneo. 


\section{Calamaria sondaica BARBOUR}

BARBour, Bull. M. C. Z., 1908, 51, p. 319.

Type:-No. 7,102, M. C. Z., one specimen, Buitenzorg, Java, April, 1907. T. Barbour, collector.

Rostral very nearly as deep as broad, easily visible from above; frontal a little longer than broad, considerably shorter than the parietals, a little more than twice as broad as a supraocular; one pre- and one postocular; diameter of the eye a little less than its distance from the mouth; five upper labials, the first nearly three times as large as the second, which is smaller than the third or fourth. These are subequal and enter the eye. The fifth is larger than the third and fourth together. A pair of infralabials in contact between the mental and the anterior pair of chin-shields. Scales in 13 rows; ventrals, 154; ana! entire; subcaudals 10. Tail rather obtuse. Dark reddish brown above (with fine plumbeous iridescence in life); six dark lines just visible on neck, very indistinct on body; rows of scales separated by zigzag white lines; a lateral white line on last row of scales. Ventral surfaces white (yellow in life), very heavily blotched with angular dark markings; a black line down midventral region of the tail, and two black lateral lines on tail.

It was with great reluctance that this new species was described. No ophidian genus cries for a revision more than Calamaria. Nevertheless, this new form seems to merit recognition on account of several distinctive characters.

Superficially, $i$. $e$. in coloration, this form does not bear the slightest resemblance to its nearest relative, which is $C$. virgulata; nor, it may be added, does it seem to agree with any of the forms which Boulenger (Cat. snakes Brit. mus., 1894, 2, p. 340) has considered synonymous with this species.

Calamaria albopunctata BARBotR.

BARBour, Bull. M. C. Z., 1908, 51, p. 319-320.

Type:- No. 7,106, M. C. Z., one specimen from the East Indies.

Rostral somewhat broader than deep; frontal longer than broad, much shorter than parietals, and less than twice as broad as a supraocular; one preone postocular; diameter of eye less than distance to mouth; five upper labials, first, third, and fourth subequal; second and fifth large; third and fourth entering orbit; first infralabial meeting its fellow behind the symphysial; two pairs of chin-shields in contact with each other. Scales in 13 rows; ventrals 247; anal entire; subcaudals 14. Tail rather blunt. Dark brown above, a lighter band 
on occiput; two outer rows of scales with light centres; lower surfaces yellow with a few dusky markings; a blackish line along lower surface of tail.

Several years ago a collection of reptiles was offered for sale which purported to come from the Moluccas, and was marked "Ternate or Amboina." Many of the specimens undoubtedly did come from the Moluccas. The Calamaria which is described above was from that collection; it reminds one strongly of $C$. occipitalis Jan, and very possibly will be found locally in some one of the many small areas in Java which are as yet unknown herpetologically.

Calamaria agamensis BleEKER.

Blegker, Nat. tijds. Ned. Ind., 1860, 21, p. 292 . Boulenger, Cat. snakes Brit. mus., 1894, 2, p. 343344.

Type locality:- "Sumatra (Fort de Kock), Borneo (Sinkawang)."

The Bryant collection contained a typical example of this species, which seems to be a very rare one indeed in Java.

Enhydris enhydris (SCBNEIDER).

Schneider, Hist. Amphib., 1799, 1, p. 245. Bodlenger, Cat. snakes Brit. mus., 1896, 3, p. 6-8.

Type locality:- Ankapilly Lake, India. From here came the specimen, taken in an eel-trap, which Russell figured and described (Account of Indian serpents, 1796, 1, p. 35, pl. 30). Russell's figure was the basis of Schneider's account, in which no definite locality is mentioned.

A single specimen from Buitenzorg, Java, while being quite typical in coloration, has but 19 rows of scales; Sc. 19 ; V. 162; C. 61 . The usual condition is 21 rows, while 23 does occasionally occur. There does not seem to be any previous note of an example with 19 rows. In life this specimen had five dark dusky stripes on a ground color which was dull lilac dorsally, and faded to light brownish gray laterally. One of the five stripes extends along the middle of the back, one along each side about halfway down, at the edge of the light and dark color-zones, and one along each side of the ventral scales. Bryant took six specimens; their scales range as follows:-V. 152-159; C. 45-57. All had scales in 21 rows.

This form has a wider range than $E$. plumbea. It is found from India and Ceylon to southern China. In both forms the range includes Malaya; through this region, however, there is little definite information as to the exact distribution. 


\section{Enhydris doriae (Peters).}

Peters, Mon. Berl. akad., 1871, p. 577. Bodlenger, Cat. snakes Brit. mus., 1896, 3, p. 13.

Type locality:- Sarawak.

It may be of interest to record a specimen of this rather rare species from Borneo, No. 5,240, M. C. Z. Shelford (Notes Sarawak museum, 1901, p. 64) states that the Sarawak museum possesses this species; and Brown (Proc. Acad. nat. sci. Phila., 1903, p. 180) records a specimen, No. 2,311, in the collection of the Academy, taken in the Kapuas River. Boulenger has one specimen from Sarawak in the British museum.

\section{Homalopsis buccata (LiNNE).}

Linne, Syst. nat., ed. 10, 1758, 1, p. 217. Boulenger, Cat. snakes Brit. mus., 1896, 3, p. 14-15.

Type locality:- "Habitat in Indiis."

An excessively variable species, which is common in all the waterways of western Java. It is readily tamed, and eats frogs, chiefly Rana tigerina and $R$. erythraea. The well-known change in color which takes place during growth has been accurately described by Flower (Proc. Zool. soc. London, 1899, p. 677678). In hand are six adults and four young from near Buitenzorg, taken in April, 1907. On account of its swimming powers one would hardly expect to find evidence that subspecific races may be developing in this form. The ten specimens mentioned above, however, have their scale-rows as follows:- one 35 , five 37, four 39. The two which Boulenger had from Java possessed 37 and 39. Bryant had six examples from Buitenzorg and Depok; their scales range:rows $33 ; 37,39$ (4 ex); V. 153-175; C. 73-91. The specimens from the mainland have a tendency to much higher numbers of rows; this is evident from material available here, and from Boulenger's data. Again, more material is necessary to show how distinct the Javan examples are from the apparently much more variable individuals on the mainland.

Range:- Southeastern Asia generally; Sumatra, Java, and Borneo.

Hurria rynchops (SchneIder).

Schneider, Hist. Amphib., 1799, 1, p. 246 . Stejneger, Bull. 58, U. S. nat. mus., 1907, pp. 304-306.

Type locality:- Ganjam, India. (Original description based on Russell, account of Indian serpents, $1796,1, \mathrm{pl} .17$ ). This town is situated in the extreme northeastern corner of the Madras Presidency, Lat. $20^{\circ} 30^{\prime} \mathrm{N}$., Long. $85^{\circ} \mathrm{E}$. It was the seat of a Resident in the days of the East India Company. It was ravaged by fever and abandoned during the early part of the nineteenth century.

This common species has a distribution very similar to that of Chersydrus 
granulatus. It is found generally along the coasts of India, southeastern Asia; in the Indonesian area it occurs generally from Sumatra to Ceram and Goram, also in the Philippines and the Pelew Islands. Schlegel (Essai phys. Serp., 1837,1, p. 171) reports its occurrence on the coasts of New Guinea. It is evidently rare there, as I was unable to find it; and recent collections do not seem to have contained it. It is unknown as yet from the coasts of Australia. On January 25, 1907, a single specimen was taken at Buleleng, Bali Island, in saltwater at the mouth of an estuary. Observations on its habits only confirm those noted by Cantor and more recently by Flower (Proc. Zool. soc. London, 1899, p. 679). This is apparently the first record of its capture on Bali, though its occurrence there was certainly to have been expected.

Fordonia leucobalea (Schleger).

Schleger, Essai phys. Serp., 1837, 2, p. 345, pl. 13, fig. 8-9. Boulenger, Cat. snakes Brit. mus., 1896,3, p. 21-22.

Type locality:- Timor.

A very variable and widely ranging form. An example here is from Penang, M. C. Z. No. 941.

Known now from nearly all coasts and rivers from Bengal to Queensland.

Boiga multimaculata (BотE).

Bore, Isis, 1827, p. 549. Bodlenger, Cat. snakes Brit. mus., 1896, 3, p. 63-64.

Type locality: - Java. While Boie does not make a definite statement as to whence his specimens came, it is quite certain that they were from Java. For he credits the name to Reinwardt, and we have evidence from Schlegel (Essai phys. Serp., 1837, 2, p. 265) that this material was collected in Java. Schlegel writes: "Cette espece inedite, également due aux recherches du professeur Reinwardt, habite l'île de Java, où elle est aussi abondante que la précédente [Boiga dendrophila] MM. Boie, Macklot, Kuhl et van Hasselt nous en ont fait parvenir un grand nombre d'individus."

This arboreal serpent is not uncommon in the vicinity of Buitenzorg. It also seems probable that a large series of specimens would show the examples from Malaya to be subspecifically distinct from those from Burma. Boie's specimens ranged in scale-counts as follows:- V. 202-213, C. 83-93. From Boulenger's data (loc. cit.) and two specimens taken in March, 1907, at Buitenzorg, it seems that Javan examples average about 206 in ventrals and 85 in subcaudals. Bryant got two at Depok, V. 217-218, C. 86-90. The range is not quite within that mentioned above for Boie's specimens. For the five specimens in the British museum from Burma and Indo-China, we have a much 
higher average; viz. V. 225, subc. 92.8. The range is also different:- V. 220227, subc. 81-100. Should we add to this series Cantor's specimen from Penang (V. 223, subc. 106), the average would be materially raised; but without a series from Penang, this example, differing so widely from all the rest, can not be considered as necessarily included in this race. 'In a general way, however, this condition of affairs is paralleled by that found in Natrix subminiata (q. v.), in which species there is a Javan form with fewer scales than in the mainland representative. In $N$. subminiata also the single specimen from Hong Kong (Bowring's) shows a condition more like the Javan than the Burmese. Bowring's specimen in the British museum has V. 203, C. 80, which is very near the average for Javan specimens, and widely different from the counts of specimens geographically much nearer.

I wish again to thank Dr. Stejneger for having a verbatim copy of Boie's description taken for me from the Isis in the Library of Congress at Washington.

This snake is known from southern China, Indo-China, Burma, Malay Peninsula, Sumatra, Java, and Celebes.

Boiga dendrophila (BoIE).

Bore, Isis, 1827, p. 549. Boulenger, Cat. snakes Brit. mus., 1896, 3, p. 70-71.

Type locality: - Java.

Boulenger (loc. cit.) gives in his synonymy of this species Coluber peruvianus Shaw (Gen. zool., 1802, 3, p. 483, pl. 122). If this species were B. dendrophila, then of course Shaw's name, however inappropriate, would have to stand. I heartily agree with Dr. Stejneger, who has expressed his opinion in a letter, that Shaw's figure and description can not be identified with this species, and probably not with any other. In this case, of course, it drops from literature, so far as this form at any rate is concerned.

In Java this snake was seen on several occasions, although no specimens were obtained. A specimen from Borneo in this Museum seems to connect varieties $\mathrm{B}$ and $\mathrm{C}$ of Boulenger; it is over five feet long. Another, smaller, example from the Philippine Islands has 76 cross-bands on the body, almost all complete, and 26 around the tail; this represents var. E, or better, perhaps, B. d. multicincta (Blgr.). Bryant had seven from Depok and one from Buitenzorg, all var. A of Boulenger. This seems to be really confined to Java. The scales range V. 218-226, C. 96-108.

Judging by Boulenger's account, there seem to be some fairly definite groupings into geographic races. There is no necessity to recapitulate these conclusions here, as the material at hand is unimportant. It seems worth 
pointing out, however, that individuals from the Malay Peninsula and Sumatra are closely similar.

Known from Lower Siam, Malay Peninsula, Sumatra, Java, Borneo, Celebes, Palawan, and Mindanao.

Boiga irregularis (BECHSTEIN).

Bechstern, Ueber Lacépede, 1802, 4, p. 239, pl. 37, fig. 1. Bodlenger, Cat. snakes Brit. mus. 1896, 3, p. 75-77.

Type locality: - Bechstein writes, "Das Vaterland ist unbekannt."

The genus Boiga was founded by Fitzinger in 1826. The type he has expressly designated as Coluber irregularis Merrem. Dr. Stejneger has kindly transcribed for me Fitzinger's own statement. "Merrem's Coluber irregularis gab Veranlassung zur Gründung von Boiga." Dumeril and Bibron (Erpet. gen., $1854,6, p .1072$ ) give a comprehensive survey of the early history of the species, and show that Merrem gave only a German name to the species when he published his original figure in 1790. This figure, Dr. Stejneger has written me, forms the basis for Bechstein's name. In 1843, Fitzinger (Syst. Rept., 1, p. 27) proposed a new generic name for this species, Gonyodipsas. It has been known at various other times by different names:- Lycodon, Dipsas, Triglyphodon, Pappophis, and Hurria. This last name Dr. Stejneger has shown (Bull. 58, U. S. nat. mus., 1907, p. 304) can be used for Hydrus rhynchops Schneider only, as the genus Hurria was founded by Daudin (Bull. Soc. philom. Paris, March, 1803 , 3, no. 72 , p. 187) for this single species. Curiously, Boulenger has not observed the necessity of using the name Boiga, but holds to Dipsadomorphus. Cope recognized the correct name, and used it for a number of species in 1860 (Proc. Acad. nat. sci. Phila., 1860, p. 264).

The coloration and number of rows of scales vary; not, however, with any relation to the geographical distribution, so far as can be learned. This snake is one of the common forms which occur over a very wide insular range; it does not reach Australia, or the continent of Asia, or the islands most closely related to Asia faunistically.

The following list of localities is gathered from various records, as well as material at hand here; and serves to show how general is the distribution of this form throughout the eastern part of the East Indian Archipelago, and through Melanesia.

The species is probably general over Celebes; it is found also on the Sanghir group towards the Philippines, though it appears to be unknown in the Philippines themselves. Among the Moluccas it occurs widely distributed, being 
known from Buru, Ambon, Ceram, Halmahera, and Ternate. It occurs on the following Papuan Islands:- Salawati, Mysol, the Ke and Aru groups; on Jobi and Sook (Misori Islands) in Geelvink Bay. On the mainland of Papua it is widespread, being known from Dorey, Mansinam, Sorong, Mt. Arfak; in northern Dutch Papua; from the Fly River country of British Papua; and from Huon Gulf, and other places in Kaiser Wilhelm's Land. It occurs on various islands in Torres Straits, in the D'Entrecasteaux group, in the Louisiade Islands; and is widely spread in the Solomon Islands, as the following list shows: Treasury, Alu (one of the Shortland group), New Georgia, Gela, and Guadalcanar.

Méhely (Termes füzetek, 21, p. 172) proposes a subspecific name for examples which he says fall in Boulenger's var. B; his examples come from various localities in German New Guinea. Werner (Verh. Zool. bot. ges. Wien, 49, p. 152) holds to this racial name of B. $i$. papuana (Méhely). A glance at Boulenger (loc. cit.) will show that specimens of his var. B come from almost anywhere, so that it can not be the basis of the name for a geographic race. The material at hand consists of one adult from Manokwari, Papua; two from Ceram, and one from Buru.

Psammodynastes pulverulentus (BoIE).

Bore, Isis, 1827, p. 547. Boulenger, Cat. snakes Brit. mus., 1896, 3, p. 172-174. Stejneger, Bull. 58, U. S. nat. mus., 1907 , p. 383-385.

Type locality:- Java.

Stejneger has given a very full account of this species, so satisfying, indeed, that the material at hand adds little to our knowledge of this form. He suggests that in the migration of this species to Formosa, its absence, so far as we know, from the mainland of China leads one to suppose that it reached the island from the south, probably from the Philippines. He adds, however, that there is "every reason to believe that $P$. pulverulentus may yet be discovered in the mountains of southern and western China." While I am not able now to add this form to the known fauna of the mainland of China, I have two typical examples from Mt. Wuchi in central Hainan. Knowing how close is the relation of the fauna of this island to that of south China, we may now be quite certain of its presence there.

These two examples have the under surface very dark brown, spotted with black. A specimen taken April, 1907, at Sindanglaia, Java, had in life a salmonpink belly, with a few scattered black specks. M. C. Z., No. 4,077 is a specimen of this species from Tay-ninh, in French Cochin-China. In this individual the belly is almost immaculate light brown. On the sides of the posterior half of 
the body there are distinct longitudinal markings. These do not show at all in either of the other specimens. Bryant has two specimens from Tjibodas, Mt. Gede, 4,500 feet; V. 152-171; C. 44-48.

Range:- Upper India through southeastern Asia to Hainan, Formosa, and the Philippines. In the Malay Archipelago it is known from Sumatra, Engaño, Java, Lombok, Flores, Celebes, Borneo, and the Natuna Islands.

In Java certainly, and probably in Hainan, it is confined to the higher elevations. It does not seem to occur at Buitenzorg, but is taken quite often at Sukanumi and Tjibodas, whence there are specimens in the Buitenzorg museum.

\section{Dryophis prasinus Bore}

Bore, Isis, 1827, p. 545. Boulenger, Cat. snakes Brit. mus., 1896, 3, p. 180-182

Type locality:- Java; collected by Reinwardt (vide Schlegel, Essai phys. Serp., 1837, 2, p. 251).

Fourteen examples of this rather common, lizard-eating serpent, taken during March and April, 1907, at Buitenzorg. In the Bryant collection, five are from Gunung Bunder, Mt. Salak, four from Depok, and eleven from Buitenzorg. D. prasinus was not taken at any of the stations at high altitudes by either of us.

Known from the eastern Himalayas through southeastern Asia to the Malay Peninsula; and in Java, Borneo, Sumatra, Celebes, Philippines, and Lombok.

Dryophis xanthozona Bore.

BoIe, Isis, 1827, p. 545. Bodlenger, Cat. snakes Brit. mus., 1896, 3, p. 180.

Type locality:- Java (fide Schlegel).

This distinct, yet really little-known, species seems to be very much rarer than D. prasinus Boie. Bryant got two specimens at Depok, Java; but none near Buitenzorg, where it seems to be unknown. However, it is probably confused regularly with its congener wherever it occurs. The range of scale-counts, so far as Boulenger knew it, was small; yet Bryant's two fall well within it:V. 187,$193 ;$ C. 130,125 . Scales in fifteen rows as usual.

Chrysopelea rhodopleuron Bore. -

Bote, Isis, 1827, p. 547. Boulenger, Cat. snakes Brit. mus., 1896, 3, p. 195-196.

Type locality:- unknown. Reported first definitely from Ambon.

A single specimen of this characteristic Moluccan species from Ambon, taken January, 1907. Scales 17 rows; ventrals 207; anal divided; subcaudals 186. The maximum number of subcaudals cited by Boulenger is 180 . 
Known from a number of the Moluccas, and from Timor-Laut. It is found upon the Sanghir Islands; and hence we may suppose that it is likely to occur in Celebes and even perhaps in the Philippines.

\section{Hydrus platurus (Linné).}

Linnt, Syst. nat., ed. 12, 1766, 1, p. 391. Boulenger, Cat. snakes Brit. mus., 1896, 3, p. 266-268. (Data on variation). Stejneger, Bull. 58, U. S. nat. mus., 1907, p. 439-442 (Synonymy and description).

Type locality:- unknown.

This form, one of the most widely distributed of reptiles, presents a perplexing problem to the zoögeographer. In the series of specimens available for study here, and with the data which Boulenger (loc. cit.) supplies, nine easily distinguishable color-phases may be recognized. To show, moreover, what slight relation these phases bear to the distribution of the snake, it may be added that six -of these forms occur in and about the Bay of Panama. Stejneger (loc. cit., p. 440) remarks that there seems to be "a certain regularity" in the distribution of these "color varieties." "Thus the ordinary black-backed form," he says, "seems to be almost exclusive in the Pacific Ocean; spotted individuals, such as the one figured in Fauna Japonica, plate viii (from the west coast of Borneo), appear to occur mostly in the Indian Ocean. All the specimens from eastern China, Formosa, Riu Kiu, and Japan, so far as the records show, are of the black-backed form." However, this same "black-backed form," which in its simplest coloration Boulenger calls $\mathrm{E}$, is known to occur from Madagascar to the eastern coast of Central America. Not so with the "spotted form," which Boulenger calls A. This appears to be rather definitely confined to the waters of the East Indian Archipelago, and may be recognized as a geographical race.

\section{Hydrus platurus ornatus (Gray).}

Color:- yellowish, dorsally with brown, black-edged cross-bands; ventrally with black bars running up the sides, and alternating with the dorsal bands.

This form is the most distinct of any of the color-phases. It shows little relation to the others, and does not seem to intergrade with them, unless we consider the rare and little-known var. maculata Jan an intermediate phase.

Gray (Zoöl. misc., p. 60) in 1842 recognized this as a distinct species, and recorded it from India. In 1896 Boulenger (loc. cit., p.'267) recorded a specimen from Borneo as "Type of $P$. ornata"; the only other specimen of this form in the British museum at that time was one from "India?." It would be interesting to know whence the type really came! Dumeril and Bibron (Erpet. gen., 
1854, 7, 2, p. 1337) record a specimen taken by Quoy and Gaimard at Makassar, Celebes. Schlegel, in Fauna Japonica (Pl. 8), figures this form; and Stejneger (loc. cit., p. 440) states that the figured specimen came from the west coast of Borneo. Russell in 1796 figured a specimen from Tranquebar, on the Coromandel Coast. In the collection of the M. C. Z. No. 938 is typical of this form, and was taken at Singapore.

This variety is still rare in collections, and curiously enough was apparently not observed by Cantor during his residence in the Straits Settlements.

As regards the var. maculata Jan, little can be said. There are no specimens here, and it appears to be rare. Boulenger described it (B, loc. cit., p. 267), but had in the British museum no specimens from known localities. It is supposed to be confined to the Indian Ocean. It may be intermediate between $H$. $p$. ornatus and some of the black-backed phases, all of which are a good deal alike.

The forms having the whole dorsal surface black or broken into confluent rhombic markings occur very widely and promiscuously. There seems to be no localization whatever amongst them. In 1906 I recorded (Bull. M. C. Z., 46, p. 227) three color-phases from the Bay of Panama; now, however, a re-examination of this material, and the study of additional specimens, show six phases occurring in this circumscribed area. Boulenger (loc. cit., p. 267-268) likewise shows that four phases occur on the coasts of India. Here, there are several well-marked phases from the China Sea. It is hardly necessary to discuss these forms in detail, for Boulenger has already described them. However, the series from Panama does contain two specimens which are noteworthy. One from Saboga Island (ex. No. 7,084, 12 specimens) may be described as follows:Dorsum black, entirely composed of confluent rhombs; lower surface olive; a yellow stripe along the side separating black from olive. In the area of the latter color occurs a series of black spots, which alternate with the dorsal rhombs. On the tail are alternating bands which arise dorsally and ventrally dovetailing into one another.

The specimens of the second lot are from San Miguel Island (ex. No. 7,083, 14 specimens), and have a black dorsum and brown belly, but lack the yellow stripe on the sides which separate these areas.

These phases may be confined to the Panamic region; but in the light of what we know of the distribution of nearly related forms, it seems much more likely that they are rare phases simply, and may turn up almost anywhere in the Indian and tropical Pacific Oceans. 
Laticauda laticaudata (LiNNE).

Linne, Syst. nat., ed. 10, 1758, 1, p. 222. StTEJNEGER, Bull. 58, U. S. nat. mus., 1907, p. 402-408.

Type locality: - The Indies.

This generic name was used by Cantor (Cat. Malay rept., p. 125) in 1847; for its history see Stejneger, loc. cit.

Dr. Stejneger in this paper has thrown a deal of light on the status of many of the sea-snakes. He has described L. laticaudata, and also L. colubrina, in such a way as to give to each full specific rank. The differences between the species would warrant this, were they constant; but since intermediate individuals occur, it seems better to consider that we are dealing with a single species, embracing two subspecifically varying forms, which occur over practically the same area. The subspecies may be known and characterized as follows: -

Laticauda laticaudata laticaudata (Linné). Scales in 19 rows. Ventrals 210-247; subcaudals 25-47. No unpaired shield between the prefrontals; upper lip often dark in color. Black annuli on body from 29 to 58 in number, on tail from 2 to 5 .

Laticauda laticaudata colubrina (Schneider). Scales in 21-25 rows. Ventrals 195-247; subcaudals 29-45. Generally an unpaired shield between the prefrontals. Upper lip usually all yellow; black annuli of body from 25 to 54 in number, on tail from 2 to 6 .

In $L$. $l$. colubrina the azygous shield is sometimes lacking, therefore we might say that these examples were specimens of the first-mentioned subspecies in which the addition of two or more rows of scales had taken place. Such a specimen from Queensland is mentioned by Stejneger (loc. cit., p. 408) as having been examined in the Christiana museum. Werner (Mitt. Zool. sammlung mus. nat. Berlin, 1900, 1, p. 104) records the existence of a similar specimen in the Vienna museum. In the collection of the M. C. Z. there are two specimens which are of interest. One is from the Indian Ocean $(4,831)$, with 23 rows of scales, and lacking the azygous shield; the other is from New Caledonia $(6,790)$. This the writer obtained at the last Paris Exposition in 1900, as it was peculiar in having a prolongation of the frontal, separating the prefrontals as if an azygous shield were present. In the series here, some twenty-five specimens from widely separated localities, no variation in the nurnber of oculors or temporals occurs in either subspecies. Nor can characters be found in the arrangements of cephalic plates or colors which regularly serve to separate these forms. The usual number of supralabials is seven in each case; eight occur on one side 
of a single individual, belonging to the subspecies colubrina; a reduction to six occurs on one side of a snake of the other series.

It is quite useless in a case of this sort to give a list of the localities whence the two forms of this species have been recorded. They have both very nearly the same range, - from the eastern coasts of India to the China Seas, and through the western Pacific as far as the Friendly and Society Islands. Stejneger records the first subspecies from as far north as Okinawa-shima, Riu Kiu Islands. The form colubrina is not known definitely from this region.

For the benefit of those who study this group it may be added that this collection contains specimens from the following localities:- Java, Singapore, Australia, New Caledonia, Pelew Islands, Philippine Islands, Ternate, and Fiji Islands, besides a number from less definite localities, as, for example, from the Indian Ocean.

Since the above was written I may add that I find that Peters and Doria, in their "Rettile e Batrachi Austro-malese," 1878, p. 412, regard the form which possesses the azygous shield as a variety of the form in which it is wanting.

\section{Pseudelaps muelleri insulae Barbour. ${ }^{3}$}

BARBoUt, Bull. M. C. Z., 1908, 51, p. 320.

Type:- No. 7,080, M. C. Z., one specimen, Djamna Island, Dutch Papua. T. Barbour, collector. Djamna is a small islet, situated off the Saär district between Cape D'Urville and Humboldt's Bay. It lies a few miles southeast of the Arimoa (Kumamba) group of islands.

Rostral scale visible from above. The eye is somewhat greater in diameter than its distance from the mouth. The scales around the body are in 15 rows; the ventrals 146, and the subcaudals 19 pairs, in number. The anal is divided. Total length $400 \mathrm{~mm}$; t tail, $32 \mathrm{~mm}$. Boulenger's (Cat. snakes Brit. mus., 1896, 3, p. 317) measurements of $P$. muelleri are as follows:- " Total length 500 millim.; tail 70."

Color:- In life this is almost coal-black above, with rich plumbeous iridescence when held in bright light. The ventral surface is, in general, dusky white. Along each of the gastrosteges runs a line of dark brown spots; these spots occur in a closely grouped cluster at the ends of each ventral scale. In the gular region the spots fuse and grow darker in color; the general effect is a very deep brown. On the lower labials small white spots occur, irregularly scattered. In alcohol,

${ }^{1}$ Recently van Lidth de Jeude has shown that this curiously colored race occurs also on the mainIand of Papua near Djauma. If this race seems to be really localized geographically, my name may stand to designate it. Cf. van Lidth de Jeude, Nova Guinea, 5, 4, 1911, p. 527-529. 
however, the black has changed to a very dark dull green, and the brown markings below to an olive color.

This form differs from Pseudelaps muelleri (Schlegel) in having a much shorter tail, fewer pairs of subcaudal scales, and a distinctive coloration. There is a typical Papuan example in the A. E. Pratt collection from Fak Fak, Dutch New Guinea.

This subspecies may be identical with " $P$. schlegelii (Günther)," which seems distinguishable as a race of $P$. muelleri (Schl.). The color of this Djamna form does not, however, seem within the variation limits of any described form.

Acanthophis antarcticus (SHAw).

Shaw, Nat. misc., 1794, 13, pl. 356 (not pl. 435, as cited by Bodlenger). Bodlenger, Cat. snakes Brit. mus., 1896, 3, p. 355-356.

Type locality:- "A native of Australasia:"

In life this snake acts much like a true viper. When angered it vibrates its tail very rapidly. The tip of the tail is armed with an elongated spine-like scale. This recalls the condition in Agkistrodon, which was considered by both Garman and Stejneger (Garman, Bull. M. C. Z., 1888, 8, p. 259-268, pl. 1-2, Science, 1892, 20, p. 17, fig. 5: Stejneger, Rept: U. S. nat. mus. for 1893, 1895, p. 337-487, pl. 1-19, fig. 1-70) as an early stage in the evolution of a rattle. In Australia this species is said to be an inhabitant of dry sandy areas; in New Guinea and Ceram, whence specimens were taken during February and March, 1907, the creature was found in damp, heavily forested areas. It is, however, quite impossible to distinguish between Australian, Papuan, and Moluccan specimens. The range of variation for the whole species, which has been well described by Boulenger, may occur in specimens from a restricted region.

This species is known in many parts of Australia; from as much of Papua as is now known herpetologically; and from Ceram, the Aru and the Ke Islands. Its distribution in the Moluccas is curiously restricted.

Bungarus fasciatus (SCHNEIDER).

Schnerder, Hist. Amphib., 1801, 12, p. 283. Bodlenger, Cat. snakes Brit. mus., 1896, 3, p. 366-367.

Type locality:- Schneider merely states that the specimen which he described was in the Museum Blochianum. At the end of his account he refers to the third plate of Russell's account of Indian serpents as an excellent illustration of the species.

A single large specimen of this dangerous species was killed while it was lying in a road near Buitenzorg, in March, 1907. While it is very much less 
common than B. candidus, it is nevertheless abundant enough to be much dreaded by the natives. Bryant had two examples from Depok.

In color my specimen is perhaps noteworthy, in that the forward prolongation of black from the first annulus reaches the internasals. Between this black and the brown on the nose is a very narrow line of yellow.

\section{Bungarus candidus (LinNe).}

Linne Syst. nat., ed. 10, 1758, 1, p. 223. Boulenger, Cat. snakes Brit. mus., 1896, 3, p. 368-369.

\section{Type locality:- "Habitat in Indiis."}

Boulenger has grouped under the name $B$. candidus three forms of serpents which, as he has shown, come from well-defined geographic areas. We have no proof that these forms merge into one another where their respective ranges meet. It seems, then, necessary, owing to their well-marked color-characters and their distribution, to call them separate species. Thus we have:-

B. candidus (Linné) from Java and Celebes.

B. multicinctus Blyth (Stejneger, Bull. 58 U. S. nat. mus., 1907, p. 397-399) from Upper Burma, China, Hainan, and Formosa.

B. caeruleus Daudin, from India to the Straits Settlements.

This last form is variable in coloration, but has not been shown to be completely connected with either of the others.

Two specimens of $B$. candidus taken at Buitenzorg, January, 1907, agree perfectly with the descriptions. When compared with a specimen of $B$. caeruleus taken at Lucknow, November, 1907, they show the following differences in addition to the well-known divergence in coloration:- the width of the head of the Javan specimens is about one fourth greater than in the Indian; the frontal in the Javan examples is very nearly as broad as long, in the Indian the frontal is one and one third times as long as broad; in the Javan individuals the length of the suture between the internasals is two thirds that of the suture between the prefrontals; in the Indian snake the first-mentioned is only one third as long as the second. In the Javan specimens the superior preocular is much larger than the inferior, while in the Indian they are of the same size. The scale-counts do not aid in separating any of the three forms. Bryant's series, ten from Buitenzorg, and two from Depok, bear out these observations. One of his specimens, however, has an almost square first temporal, a curious anomaly. 
Naja naja (LINNE).

Linne, Syst. nat., ed. 10, 1758, 1, p. 221. Boulenger, Cat. snakes Brit. mus., 1896, 3, p. 380-385. StejNeger, Bull. 58, U. S. nat. mus., 1907, p. 394-397.

Type locality:- "Habitat in India orientali."

Stejneger has outlined a scheme for the study of the varieties of the cobra which is an advance over that of Boulenger. The latter grouped them according to color alone, and we had as a result a curious series of subspecies in any one of which might occur specimens from almost any locality. As a matter of fact, by using the scale-counts of Boulenger and those of Stejneger, we may define in a fairly satisfactory manner several apparent geographic races in the East Indian region.

Naja naja leucodira (Boulenger, loc. cit., p. 384).

This form seems to be confined to Sumatra, whence specimens have come to the British museum. Examples also exist in the zoölogical museum of the Department of agriculture at Buitenzorg, Java.

Body with no marking above; dark brown, almost black. Hood unmarked. Throat whitish, usually spotted with black, and with a black band. Scales on neck 21-25; generally 23 ; 17 or 19 rows across body. V. 183-193; C. 50-55.

N.n. sputatrix (Boie). Isis, 1827, p. 557).

I add here a transcription from a letter from Dr. Stejneger copying Boie's text. Under $N$. tripudians Boie writes, "Im Pariser Museum Exemplare von Java, Sumatra und den Philipinen, die kaum specifisch verschieden zu seyn scheinen. Bey javanischen Exemplaren die Brille undeutlicher, die Lippen ungefärbt."

"6. sputatrix Reinw. Russell, Account of Indian serpents, 1796, 1, 2, tab. 36. Elaps fuscus Merr. Coluber castaneus Oppel, cf. Erpet. de Java.

"Oculis parvis, cauda $\frac{1}{6}$, tota e badio aenea, capite dilutiore, cervice in juniore subperspicillato, $173-80=50-52 . "$

Javanese cobras show a remarkable constancy in the number of rows of scales on the neck. This appears to be regularly 25, while the number of rows around the body may be 19 or 21, the latter being most frequent. Boulenger has recorded three specimens from Java belonging to two varieties. Two (loc. cit., p. 382) as var. caeca, and one as var. sputatrix. The scale-counts in all lie within these limits, viz. Sc. $\frac{25}{21}$; V. $172-180$; C. 44 for the first two mentioned; and Sc. $\frac{25}{19} ;$ V. 163 ; C. 44, for the single N.n. sputatrix. The following counts, taken from seven specimens all from near Buitenzorg, show the range in a restricted locality. They can not be separated on a color-basis, and are all $N, n$. 
sputatrix. Sc. $\frac{25}{21}, 175,52$. Sc. $\frac{25}{19}, 173,50$. Sc. $\frac{25}{21}, 176,51$. Sc. $\frac{25}{19}, 173,50$. Sc. $\frac{25}{21}, 175,52$. Sc. $\frac{25}{21}, 171,50$. Sc. $\frac{25}{21}, 183$, ?. The range may be expressed as Sc. $\frac{25}{19-21}, 163-183,44-52$. Curiously, the highest ventral count of a Javan individual is the same as the lowest ventral count of a Sumatran.

The coloration of this form is usually very dark brown or black above, yellowish on chin. A complete or broken circular mark is usually present on the hoods of the young. The marks on the hoods of most adults are nearly vanishing; hence, perhaps, the recording of two by Boulenger as var. caeca, which has the hood regularly unmarked.

N.n. miolepis (cf. Boulenger, loc. cit., p. 384-385).

The Bornean form may be distinguishable by the peculiar marking in the young. A scale-formula based on Boulenger's data is Sc. $\frac{21-23}{17-19} ; 181-199 ; 45-$ 51. In this case all of the specimens identified with this race come from a single region.

N.n. atra (Cantor). (Stejneger, loc. cit., p. 395).

To this form a single specimen, from Ting-an, Hainan Island, seems referable; its scales count $\frac{25}{21}, 173,43$. A young specimen agreeing well in color and squamation with Stejneger's description of a young Formosan example. It differs, however, in having the "white rimmed spectacles" lying in a broad black band, and the general ground color olive-green.

The great difficulty in reaching any general conclusions in regard to the geographical races of this form is the lack of material in large series from wellauthenticated localities. When we have records of scale-formulae for hundreds of cobras where we now have tens, we may be able to reach conclusions which are safely tenable.

Provisionally, following Stejneger so far as he went, we may summarize our information concerning these races as follows:-

Naja naja (Linné).

Many scales about neck, 29-35 (sometimes 27). Sum of ventrals and subcaudals averaging about 230. Range:- India, Ceylon, Burma, Malay Peninsula.

N. n. oxiana (Eichwald).

Ventrals and subcaudals averaging 268. Transcaspian region.

Then follow:-

$N$. n. leucodira from Sumatra.

$N$. n. sputatrix from Java and possibly part of Sumatra.

N.n. miolepis from Borneo and Palawan. 
$N$. n. atra from the Siamese and Chinese regions.

To the above may be added:-

$N$. n. paucisquamis; this is known from a single specimen taken in Borneo. Peracca, after correspondence with Boulenger, proposes (Rev. Suisse zool., 1899, 7, p. 328) the name for an example with 19 rows of scales on the neck, and 15 on the body. He mentions 46 subcaudals, and coloring similar to $N . n$. miolepis.

Since the preceding pages were written, Bryant's Javan cobras have come to hand, and bear out what has been said as to the ventral counts of Javan and Sumatran specimens just meeting but not overlapping in numbers. From the nine specimens which Bryant preserved at Buitenzorg and Depok we get the following counts: - Ventrals 166-180, subcaudals 45-53. These counts are almost the same as those taken from my specimens. Bryant's show a greater variability in numbers of rows on both neck and body. Instead of these being expressed by the formula which I gave before, $\frac{25}{19-21}$, we must now write $\frac{23-25}{19-23}$. Only the ventral counts, then, distinguish Javan from Sumatran cobras.

\section{Doliophis intestinalis (LAURENTI).}

Plate 5, fig. 16; Plate 6, fig. 17.

Ladrenti, Syn. Rept., 1768, p. 106. Boulenger, Cat. snakes Brit. mus., 1896, 3, p. 401-404.

\section{Type locality: - "Africa."}

An excessively variable species. Studies of material from Java and Penang in the collection of the M. C. Z., and data made available by Boulenger, lead me to conclude that this form is not divisible into subspecies. Color varieties which embrace examples from widely separated localities express no relationship, and hence do not merit a name. The averages obtained by adding the number of ventrals and subcaudal scales of specimens from the same locality teach us little. Thus, seven specimens each from Java, Sumatra, and Nias, and from the Straits Settlements, give averages respectively as follows:-267.7, 261, and 260.4. Twelve specimens from Borneo and Labuan give an average of 258.3. And finally a specimen from Menado in northeastern Celebes has scales which total 262. The Javan average is raised by the counts of two specimens which have extremely high scale-counts,- 294 and 287 . This is paralleled by a single specimen from Singapore with 288, and one from Borneo with 283. If we had fifty specimens from each of these localities, we might be able to separate satisfactorily a Bornean form; for these do seem to have a smaller average than those from the other islands. With small series, and from scattered parts of the various regions, it seems unwise to try to separate races, especially since color 
is valueless. A glance at Boulenger's account of this form will show that variety A occurs in Java and Borneo; B in Straits Settlements and Borneo; $\mathrm{C}$ in Straits Settlements, Sumatra, and Borneo; E in Borneo and Sumatra; $\mathrm{F}$ in Borneo and Celebes. Of variety $\mathrm{D}$, only one specimen is in the British museum; and of $\mathrm{G}$, only two; both taken at the same time. These varieties have been given names by Boulenger; and these do doubtless afford useful handles by which to speak of the different specimens, but they do not seem to express anything which is valuable to the zoögeographer or student of ophidian relationships. It is noteworthy that all the specimens at the Buitenzorg museum, as well as three taken at Buitenzorg and now in the collection of the M. C. Z., had the coloration designated A by Boulenger. Inasmuch as this phase also occurs in Labuan, we can not name it as a local race, however. Since the above was written, Bryant's series has brought in seven from Buitenzorg, and four from Mt. Salak, all of var. A, the only one occurring in Java.

Annandale has noted the very large size of the poison-apparatus of $D$. bivirgatus in the Malay Peninsula; and Gadow, in his Amphibia and reptiles, 1901, p. 634, has mentioned it for this species (see fig. 17). Boulenger (loc. cit.) notes the pushing of the heart to a position far posterior of its characteristic position. This apparatus is figured here because none of these accounts give one a definite idea of the enormous development of the glands, and this condition seems to be quite unknown to the average comparative anatomist.

The curious habit of crawling with the tail up-turned to show the brilliant red under color is also figured. This has been noted before by Annandale (Fase. Malay. Zool., 1903, 1, p. 167-168). Flower (Proc. Zool. soc. London, 1899, p. $693, \mathrm{pl} .37$ ) has described and figured the same habit for Cylindrophis rufus. In spite of the enormous poison-glands, and the widespread native suspicion directed against all the red-tailed snakes, it seems very unlikely that this reptile can be considered a really dangerous form.

\section{Amblycephalus carinatus (WAGLER)}

Wagler, Nat. syst. Amphib., 1830, p. 181. Bodlenger, Cat. snakes Brit. mus., 1896, 3, p. 445-446.

Dr. Stejneger writes me that $A$. carinatus Boie is a complete nomen nudum. Reinwardt had sent specimens to Leyden, using this MS. name, which Boie simply copied. Dr. Stejneger points out that this evidently happened before Boie himself left Holland. The authority for the name must therefore stand as Wagler. He described the species as the type of a new genus, Pareas; and, just as Dr. Stejneger also has written me, credits the name "Dipsas carinata" to "Reinw. in Mus. Lugd." The type locality, then, is Java. 
Apparently this species, like Lachesis puniceus (q.v.), is chiefly confined to high altitudes. It is rare, and most of the specimens in the excellent collection of Javan reptiles in the Museum of the Agricultural department at Buitenzorg came from levels higher than that of Buitenzorg. While collecting in the vicinity of the Mountain Gardens at Tjibodas, several specimens were taken at an altitude of about 4,500 feet on the slopes of the volcano Pangerango. Others were brought to Buitenzorg by natives, who had taken them on neighboring highlands. Seven specimens, all told, were preserved; and they agree well with Boulenger's description. Color is brightest, and carination most distinct, in young specimens. It remains tightly coiled unless much disturbed. Under provocation, however, it will strike very viciously. It may be added that Bryant, had six specimens from Buitenzorg, and two from Depok. They may have come from the hill regions near by.

This form has been recorded from both Cochin China and Burma, in both of which localities it seems to be rare. Mouhot's specimens in the British museum came from the Laos ("Lao") Mountains, and it is quite possible that care- ful collecting among the higher mountains of Burma and Cochin China would prove that the species was as exclusively a highland form on the continent as it seems to be in Java.

\footnotetext{
Agkistrodon rhodostoma (BoIE).

BoIt, Isis, 1827, p. 561. Boulenger, Cat. snakes Brit. mus., 1896, 3, p. 527-528.

Type locality:- Java.
}

This large and dangerous creature is abundant in western Java, mostly in heavily forested areas at more than 1,000 feet elevation. Its coloration of beautifully blended shades of lilac, violet, and rich brown makes it most difficult to see, as it lies tightly coiled on the ground, with a background of decaying leaves. Contrary to Annandale's field notes, which Boulenger has quoted (Fasc. Malay. Zool., 1903, 1, p. 170-171), the natives of Java realize full well how dangerous this form must be. The fangs are excessively long, and the actual quantity of poison secreted is very great indeed. In the young of this species, about the last inch of the tail is bright yellow. This feature is also conspicuous in the congeneric forms of North America. In all, as the individuals grow older, small spots appear on the dorsal surface of the tails; and as these increase in size and number they spread down on the sides; so that by the time the specimens are eighteen inches long, the yellow may be seen only after careful examination. In $A$. rhodostoma it persists a very long while - certainly until full growth is reached - as narrow bands between the dark spots. This does not seem to be 
the case in $A$. contortrix and A. piscivorus; in both of these it disappears before adult size is reached. The largest specimen measured by Boulenger (loc. cit., p. 528) was $900 \mathrm{~mm}$., total length of body and tail. In a series of eight examples taken near Buitenzorg during March and April, 1907, one measures 1,030 mm. total length. In all, the number of rows of scales was 21; ventrals ranged from 144 to 157 , and subcaudals from 38 to 53 .

The history of our knowledge of this form is curious. When Boulenger, in 1896, wrote vol. 3 of the British museum catalogue, this species was definitely known only from Java, whence Reinwardt had taken it, and whence the example for Russell's (Account of Indian serpents, 1801, 2, pl. 21) figure had come. There was a specimen known bearing the label "Siam." Six years later the first part of the Zoology of Fasciculi Malayenses appeared, papers based on the collections of Annandale and Robinson in Perak and the Siamese Malay States. For this Boulenger prepared a list of Malayan reptiles as an appendix to his study of the collections entrusted to him. He notes that $A$. rhodostoma does occur in Siam, whence a specimen has been received by the Christiania museum; and also records it from Biserat, Jalor, Malay Peninsula. Annandale says that it is not rare, and it is remarkable that it remained so long undiscovered. Strangely, it has not been found in Sumatra as yet. As Boulenger notes, a parallel case to this discontinuous distribution is afforded by Geoclemys ${ }^{1}$ subtrijuga (Schl. en Müll.), and other species which are mentioned passim.

I got a series of specimens from Buitenzorg; and Bryant took thirty-one:one at Gunung Bunder on Mt. Salak, elevation 2,200 feet; eighteen at Depok; eleven at Buitenzorg; and one at Daru in Bantam.

\section{Trimeresurus puniceus (BoIE)}

Bote, Isis, 1827, p. 561. Boulenger, Cat. snakes Brit. mus., 1896, 3, p. 560-561.

Type locality: - Java, collection of Reinwardt (vide Schlegel, Essai phys. Serp., 1837, 2, p. 545).

This form in western Java is an inhabitant of deep forests at high levels. Major P. A. Ouwens of the Buitenzorg museum told me that it was never taken near Buitenzorg. On the higher volcanic peaks near Soekaboemi it occurs sparingly. Two specimens were taken at an altitude of from 4,500 to 5,000 feet during April, 1907. Bryant took it only on Mt. Salak, where he got six specimens. One of my specimens is now in the Museum of the Department of agriculture at Buitenzorg, and the other is before me. The color has hardly changed

${ }^{1}$ For the use of Geoclemys instead of Damonia, cf. Stejneger, Bull. 58, U. S. nat. mus., 1907, p. 496 
from what it was in life. Rich reddish brown, with some faint darker markings; a very faint whitish line running through the eye, and some yellow scales laterally near the gastrosteges, which are dark yellow specked with slate color. This form in life is excessively sluggish; when aroused, however, it strikes viciously, and with a speed which is, I think, quite unexcelled. Though the tail is strongly prehensile, the natives say that this form is generally found on the ground.

Curiously, this form, while occurring on the Natuna group of islands, Sumatra, and Borneo, does not occur on the mainland. It would be most interesting to know whether its occurrence at high levels is as constant throughout the rest of its range as it is in western Java. In the Natuna group there is a hill on Great Natuna; but the rest of the islands are, so far as can be learned, low lying.

\section{Trimeresurus wagleri (ScHLEGEL).}

Schlegel, Essai phys. Serp., 1837, 3, p. 542, pl. 17, fig. 16-18. Boulenger, Cat. snakes Brit. mus., 1896,3 , p. 562-564.

Type locality: - Sumatra.

This species is attributed to Boie, Isis, 1827, p. 561, by Boulenger, but Dr. Stejneger writes that there is no diagnosis whatever. Boie referred to "Col. sumatranus Raffles," and to "Seba T. ii, tab. 68, fig. 4." These snakes are different species, and it was Schlegel who definitely fixed $T$. wagleri to the snake for which the name is now used.

Two specimens from the Philippine Islands, belong to phase B of Boulenger. It is interesting to compare the distribution of this species with that of T. gramineus (q.v.). This form has reached Sumatra, Borneo, Celebes, Philippines, Sirhassen, and Natuna Islands, occurring also on the Malay Peninsula.

\section{Trimeresurus gramineus (SHAw)}

Shaw, Gen. zool., 1802, 3, p. 420. Stejneger, Bull. 58, U. S. nat. mus., 1907, p. 480.

Type locality: - Vizagapatan, India. (Based on Russell's Account of Indian serpents, 1796, 7, pl. 9).

The green tree-vipers are either extremely rare in Java, or else their coloration makes them so hard to find that they are seldom taken. The former presumption is undoubtedly correct, since such green species as Gonyosoma oxyrhynchus are very often found.

The only Javan specimen seen was one adult taken by Bryant at Buitenzorg. 


\section{TESTUDINATA.}

\section{Geoclemys subtrijuga (Schlegel en MÜLleR).}

Schlegel en Müller, Temminck's Verh. Natuur. Ned. Ind. Rept., 1844, p. 30. Bodlenger, Cat. chelonians *** Brit. Mus., 1889, p. 94.

Type locality: - Java.

Three examples from Depok, Java, in the Bryant collection.

This species is mentioned (p. 23) on account of its interesting distribution. It is one of the many species which occur on Java and the Asiatic mainland without as yet having been found in either Sumatra or Borneo.

Orlitia crassicollis (GRAY).

Grat, Synop. Rept., 1831, p. 21. Boulenger, Cat. chelonians *** Brit. mus., 1889, p. 98.

Type locality: - Sumatra. Boulenger records the shell of a half-grown individual in the British museum, the gift of Thomas Bell, Esq., as being the type from Sumatra.

Bryant sent two examples from Depok. The species does not appear to have been taken in Java previously. Being unfamiliar with East Indian freshwater tortoises and having but little identified material at hand for comparison, I concluded that I had to deal with what is generally called Cyclemys dhor (Gray) (Blgr. loc. cit., p. 131). In this, as in many other matters, Dr. Stejneger set me aright; but our study and discussion of the latter species led to some interesting results affecting this name, so long used. Gray's Synopsis Reptilium is not in the library of the M. C. Z., but I have the following information sent me by Dr. Stejneger taken from his copy of this rare work.

In the first place Boulenger (loc. cit., 1889, p. 131), alluding to the original description of Cyclemys dhor refers to Gray, Synopsis Reptilium, 1831, p. 23. This is an error, the description being on p. 20. Concerning this name and the type locality of the species, Dr. Stejneger writes me that he has come to the following conclusion:-

"Gray's Emys dhor, p. 20, corrected to E. dentata on pp. 79 and 80, and figured on pls. 8 and 9, is a compound based in part upon (Hardwicke's drawing of) a Bengal specimen, and in part upon three young (apparently from Java).

"p. 20 "Emys dhor. Gray Illustr. Ind. Zool., apparently not yet, 1851, published ( $\bar{v}$. Mus. Brit.) Emys Hasselti, Boie Mss. (v. Mus. Leyd.)

" Habitat in Bengal, called Dhor and Thum, General Hardwicke, Java, Van Hasselt. (v, v. Hort. Zool. Bell et nostr.) 
"'Like the former, only known from three young specimens, p. 21 one of which, given me by Mr. Bell, I kept alive for some time.'

"In 1844 (Cat. Tort. Br. Mus.) the two species are still confounded under the name Emys (Cyclemys) dentata, inasmuch as he still quotes pls. 8 and 9, though only enumerating specimens from Java.

"In 1855 (Cat. Shield Rept., p. 35) he realizes his mistake and quotes pl. 8 under Batagur baska as the young, although by a lapsus he still quotes ' 8 , 9' under Cyclemys dentata (p. 42), which he now assigns exclusively to Java and Borneo.

"Finally in 1870 (Suppl.) he returns to the name dhor for the exclusively Javan species without giving any reason.

"I believe dentata should take the precedence over dhor, and that Java must be considered its type locality."

Cyclemys amboinensis (DAUDIN).

Daudin, Hist. nat. rept., 1802 (1803), 2, p. 309. Boulenger, Cat. chelonians *** Brit. mus., 1889, p. 133.

Type locality:-Ambon.

This species inhabits ponds and sluggish streams. It is usually the most common chelonian where it occurs. I preserved eight specimens from Makassar, Celebes, and three from Buitenzorg. Bryant got one at Buitenzorg, and one at Depok, Java. A topotype has been received with a recent acquisition.

The two editions of Daudin's Histoire naturelle.... de reptiles are somewhat confusing as to dates. One, bearing the title "Histoire naturelle generale et particuliere des reptiles; ouvrage faisant suite a l'histoire naturelle generale et particuliere, composee par Leclerc de Buffon, et rediger par C. S. Sonnini, ... . 8 vols. Paris," appeared as follows:- Vols. 1-4, An X (1802), and vol. 5-8, An XI (1803). As Dr. Stejneger writes me in sending data regarding his copy, quotations occur throughout the whole work from Latreille's Histoire naturelle, which appeared in 1802; so that the whole of Daudin should be dated at the earliest 1803.

The other, rather more common edition bears a slightly different title:"Histoire naturelle generale et particuliere des reptiles; ouvrage faisant suite aux oeuvres de Leclere de Buffon, et partie du cours complet d'histoire naturelle redige par C. S. Sonnini,... .8 vols. Paris." The volumes are curiously dated as follows: Vol. 1-2, An XIII (1805), vols. 3-4, An X (1802), Vol. 5-8, An XI (1803). 
There are many sets which are composed of some volumes from each edition.

$$
\text { Amyda subplana (GEOFFroy). }
$$

Geofrror, Ann. mus., 1809, 14, p. 11, pl.5, fig. 2. Boolenger, Cat. chelonians * * * Brit. mus., 1889, p. 253.

Type locality:- unknown.

This turtle occurs in apparently about equal numbers with $A$. cartilaginea. It lives in the same sluggish waters. I preserved one example, and Bryant two, from Buitenzorg.

\section{Amyda cartilaginea (BODdAERT).}

Boddafrt, Epistola ad W. Roëll, cum tab., 1770 (fide Boulenger). Boulenger, Cat. chelonians $* * *$ Brit. mus., 1889, p. 253.

Type locality:- original description not seen.

This species is abundant in the sluggish ditches and flowed rice-fields about Buitenzorg. Each of the collections examined from there contained two small examples. 


\section{PART III.}

\section{TABLE OF DISTRIBUTION.}

In preparing the table of distribution it has been necessary, in order to keep it in convenient form, to limit the number of localities included. Thus, the Philippines have been taken together, even though conditions vary greatly upon the different islands. Again, species have been described which are apparently confined to some small islet, and in these cases they have been credited to the nearest listed locality to which they belong faunally or geographically. For instance, Dasia aignanum (Boulenger) was described from St. Aignan's Island in the Louisiade Archipelago; but this species has been credited to British New Guinea, a region of which the Louisiade Archipelago forms simply a disjointed part, and to which the group belongs both zoölogically and geographically.

For the table see p. 169-203.

\section{ZOÖGEOGRAPHY.}

The conditions which limit an attempt to use the data of the geographic distribution of animals as an aid in reconstructing past geographic changes in the East Indies are very many. In the first place, an accurate, systematic knowledge of the fauna of any one East Indian Island is still far from an accomplished fact. Of many islands we know nothing at all. We may wish to argue from what we know of the Amphibia of one island, and to compare this with the conditions on another island where the birds are well known, but the amphibians little, or not at all. Again, we know that species often become extinct, especially upon islands, for no apparent reason; so that we may be constrained to argue from the absence of certain forms, and yet never feel sure that they have not existed in the past.

Conditions of life on islands, as elsewhere, are subject to certain purely economic conditions: beasts of prey demand the presence of a definite number of plant-eating animals, the latter demand the proper food supply of plants. Insectivorous animals must have insects; and insects must have appropriate plants, each in definite supply. Thus a certain balance must always be maintained; and this may be accomplished at times only by the dying out of some of 
the forms which have been left imprisoned, as it were, upon any island at the time of its separation from the land with which it formerly was in connection.

Zoölogic evidence can never outweigh or set aside positive geologic evidence. It can never hope to place the time of a geologic change with the accuracy that geologic evidence does, when the latter exists. Unfortunately, convincing geologic evidence is, in this region, frequently wanting. In the East Indies, as in the West Indies, we may, it is true, postulate extensive land connections as existing in a recent geologic past, and as having only in some cases left behind them evidence of their existence in the shape of elevated ridges or shallow areas on the bottom of the sea.

The origin of the fauna of the West and East Indian areas presents a condition of affairs singularly parallel. In the West Indies there has been an immigration of land types into Haiti and Porto Rico, and thence to the Lesser Antillean chain, which have come by land connections stretching from Cuba to Yucatan, on the one hand, and to Haiti on the other; and again from the Mosquito Coast to Jamaica, and thence to Haiti. There has also been a connection of Florida with Cuba, and of Cuba with the Archipelago of the Bahamas; for these islands have drawn more of their fauna from Cuba than they have from Haiti, though the latter is nearer to some points of the Bahamas. Then, up to the Lesser Antillean chain has come an immigration of animals which have been derived from the region of Archiguiana, or part of the Gondwana land of Suess (Face of the earth; translated by Hertha B. C. Sollas 4 vols., Oxford, 1904-1910; 1, p. 387; 4, p. 471, 663). This faunal element from what is now northeastern South America is predominant in Trinidad and Tobago, recently separated; very strong in Grenada; and less so in St. Vincent. It reaches up to Porto Rico, where it still forms a prominent part of the whole fauna, and is naturally less evident in Cuba and Jamaica (Barbour, Bull. M. C. Z., 1910, 52, p. 275-285).

In the East Indies the case is more complicated, but the main features of the two-fold origin are the same - an influx of mainland types from southeastern Asia, on the one hand; and an influx of types derived from Antarctis, on the other (Antarctis = Australia + Patagonia. Cf. Suess, 4, p. 667-669).

The points of view of both zoölogist and geologist are fast changing regard- ing the extent to which one may assume that alterations have taken place in the shape of existing land-masses. There has been up to recent times a strong tendency on the part of English, and some American, geologists to look upon the ocean basins as fundamental surface features of the earth, which have existed 
practically unchanged since its geologic infancy. There has been an inclination to look askance at those who do not believe in the permanence of land forms almost as they exist today. Suess, however, says that "the crust of the Earth is traversed not only by isolated faults, *** but by whole systems of fractures, that extensive areas have thus been broken up, and have foundered into the interior of the planet" (Suess, 1, p. 7). Again, he remarks that the enthusiasm which we have expended in contemplating the part that the little polyp has played in building up the coral reef, or that the rain-drop has performed in hollowing out the stone, have brought the commonplaceness of everyday life into our conception of the phenomena of the past. In his opinion the convulsions which have affected parts of the crust of the earth have been greater, and of greater frequency, than was formerly supposed. "The earthquakes of the present day are certainly but faint reminiscences of those telluric movements to which the structure of almost every mountain range bears witness." Enormous changes of level have taken place upon the surface of the earth in such recent times, geologically speaking, that one can fairly consider these changes to be hardly less than others whose existence can not be proved geologically. These supposedly have been brought about by the folding of the surface of the earth, or by depression of those areas of the lithosphere which, once dry land, now lie deep below the sea. The elevated valley of California, and the upper valley of the Po in Europe are excellent examples of regions where enormous changes of level of land in relation to sea have taken place since late Pliocene and probably even since early Pleistocene times. The northeastern coast of North America is fast sinking at the present. Where lines of recent volcanic activity, as in the East Indian and West Indian Island areas, occur, one may fairly assume that fundamental changes of level have taken place, or may take place in any short space of time. These regions lie in geosynclines, areas where changes of level are most likely to occur, for there folding and faulting are at a maximum. Prof. J. B. Woodworth has told me that he considers it as not at all an extravagant statement to say that, so far as the geologic evidence is concerned, the Brazilian highland area may be projected indefinitely into the Atlantic basin; and the same thing is true of the probable projection of the Chilean region into the Pacific. He has recently studied both these regions in great detail. The geologic evidence as to the great age of the Atlantic Ocean is purely negative. So late as the Upper Trias there were, except for a small area in the Atlas Mountain region, no marine sediments laid down by the existing shores of the Atlantic.

We know that the facility with which animals of various orders are trans- 
ported across the open sea fortuitously, or by what has been called flotsam and jetsam dispersal, is much less than was previously supposed. I have discussed this question at considerable length in "Notes on the herpetology of Jamaica" (Bull. M. C. Z., 1910, 52, p. 280-284). To attempt to trace the history of this change of opinion would be a long task, and would have no place in this connection. Many naturalists still adhere to the old views, and there can be no doubt that in certain cases fortuitous distribution does play some part in providing continental islands with faunae. Generally speaking, however, it is a negligible one; and the tendency is stronger and stronger to conclude that the dry surface of the earth has undergone enormous and fundamental changes in extent since life has been existent. Thus, the Galapagos Islands, considered by Darwin, Wallace, and others as typical oceanic islands, are in all probability truly continental in nature; at least this opinion is gaining ground ( $c f . G$. Baur, Amer. nat., 1891, 35, p. 217-229, 307-326; also Amer. nat., 1897, 31, p. 661-680).

So also with the Azores, Madeira, and the Canary Islands.

The marvellous land-snail fauna of some of the Pacific Islands, especially of the Hawaiian Islands, is no longer considered as consisting only of individuals which reached the island fortuitously; but rather as an enormous group of species, greatly modified and divided up amongst themselves through long isolation upon the different islands, or even in the different valleys of the various islands; and, moreover, these species are shown to be the descendants of ancient types. If individuals in the past occasionally reached the islands by floating, they would still do so once in a while. An influx of continental individuals would tend, of course, to keep the groups of individuals upon the islands more or less like those upon the shores whence the immigrants came. That this is not the case has been most ably argued by Pilsbry (Proc. Acad. nat. sci. Phila., 1900 , p. 568-581), who shows that, in the first place, many genera of land-snails reach back to the Oligocene unchanged in specific characters; and that the modern family groups of snails diverged far back in Mesozoic time. This shows the difference in the conditions which one finds in dealing with the fauna composed of invertebrate groups of animals alone. A land-mass cut off in early Tertiary times might lack most mammals, and yet present molluscan genera identical with those upon other land-masses, or upon the continents. This, in brief, is the basis of the argument which Pilsbry employs in commenting upon the antique character of the Polynesian snail fauna. After mentioning the primitive character of the Orthurethra, Heterurethra, and the Sigmurethra (Aulacopoda), he shows their astonishing abundance in Polynesia, along with the absence of 
such typical recent families as Helicidae and Bulimulidae, and others, which are the very families known to be most successful as emigrants; for species of these modern successful families follow modern agriculture and commerce about the world, and easily become established. Some of these have come to Polynesia within historic times; but we find none existing as a part of the true fauna of any island. Thus Pilsbry continues, "the advocate of a Polynesian waif fauna is then compelled to adopt the view either that accessions to the mid-Pacific snail faunas practically stopped a long time ago, from causes unknown or hypothetical, or that an unparalleled series of accidents intervened to prevent the, in recent times, ubiquitious and prominent continental groups of snails from effecting a landing in these islands." In continuing he shows how wrong Wallace was in deriving the Polynesian fauna from the Australian region, and says: "Far from being a faunal dependency of the Australian or Oriental regions, Polynesia has every appearance of being a region which started with a fauna long antedating the present Australian and Oriental faunas, developing along its own lines, retaining old types because they did not come into competition with the higher groups developed on the greater and less isolated continents *** On the supposition that Polynesia has always had the constitution the name implies, it is difficult to see why agencies which introduced representatives of some eight families of snails into the Hawaiian group should totally fail to act during the mesozoic and tertiary. Even Wallace felt that some explanation was called for, and speaks vaguely of the 'extensive shoals to the south and southwest,' and 'two deep submarine banks in the north Pacific between the Sandwich Islands and San Francisco." Again Pilsbry says, "In writing that "none of these oceanic archipelagos present us with a single type which we may suppose to have-been preserved from mesozoic times' $(l$. c., p. 305), Wallace makes a statement totally at variance with the nature of their land molluses." Crampton has told me that he has arrived at similar views by studying the Partulae of Tahiti and other islands where they occur.

These quotations are made here simply to show how an opinion, almost universally held at one time, has had to give way to the newer interpretation of conditions in the Polynesian Islands based upon fuller collections and a better knowledge of palaeontology.

In the East Indies the islands have always been considered to be of continental origin; so that the question is not one of whether the islands have ever been connected with one another, and with the mainland, but rather one of the exact conditions as regards land-bridges and their positions. Scharf, in his 
address before the Seventh international zoölogical congress on The evolution of continents as illustrated by the geographical distribution of existing animals (Proc. 7th intern. zoöl. congr., 1907, 1909, separate, p. 10-11, 1912, p. 864-865), wrote:-

"Within recent years, it has been shown that Australia must have been joined to Asia by land. This land-bridge existed, no doubt, in rather remote times, probably towards the close of the Secondary era, and became broken up perhaps during the eocene period.

"Wallace acknowledged that the Asiatic mainland extended as far to the southeast as Borneo within comparatively recent times, and that a large tract of country had since sunk, so as to produce the present configuration of the IndoMalayan region. He was particularly impressed by the apparent sharp line of demarcation in the faunas between the small islands of Bali and Lombok, and assumed that the latter were separated by a marine channel of great depth. It has been now clearly established, however, by Weber, that no such deep channel intervenes between these islands, and that their faunas are by no means so distinct as Wallace supposed.

"The faunistic relationship of the numerous islands of the great IndoAustralian archipelago and their geological history is being energetically worked out at present with the aid of the geographical distribution of animals.

"Since Wallace's classic investigations in this archipelago, foremost in importance from our point of view are the researches of the two Sarasins. Their remarkable work on the geological history of the island of Celebes, based on animal distribution, may truly serve as a model to those prepared to devote themselves to pursuits of a similar nature. From the time, in the dawn of the Tertiary era, when the island was still submerged by the sea, they trace its gradual evolution, the geological history of its immigrants, and its final separation from other land masses. They show that though Celebes was connected with Australia by way of New Guinea, westward with Java, Sumatra and the Malay peninsula, and also northward with the Philippine Islands, the Strait of Macassar always separated it directly from Borneo."

Again, later still, van Kampen, in a paper entitled "De zoogeografie van den Indischen Archipel" (Nat. tijdschr. Ned. Ind., 1909, separate, p. 1-24) has given us an excellent historical account of East Indian zoögeography. An English translation of this paper will be found in the American naturalist, 1911, 45, p. 537-560. It seems hardly worth while to repeat here a discussion of the work of Müller, Earle, Wallace, the Sarasins, Max Weber, Pelseneer, 
and others who have studied in these fields, since van Kampen has so recently reviewed their labors.

The most of the land connections by which each island, or group of islands, has received its present fauna have been dealt with elsewhere in this paper. We may sum up the present state of evidence by saying that, in order to account for conditions as we find them now, it must be conceded that since Cretaceous times there has existed a general land connection between southeastern Asia and the islands Sumatra, Borneo, and Java; and, at the same time, a connection between Borneo and Palawan, and possibly some other of the southern Philippines. Important evidence for this is the finding in Java of Tertiary fossils belonging to such characteristic mainland genera as Hyaena, Stegodon, Hippopotamus, several antelopes, etc. Then, at the other end of the group, New Guinea must have been widely connected with Australia, though this connection will need discussion to show why so many characteristic Australian types are lacking in Papuasia. New Guinea was connected in Eocene times, and probably later, with a great stretch of land which extended down to the southeastward, including certainly what are now the Bismarck Archipelago, the Solomon Islands, New Hebrides, Fiji, and probably New Caledonia, and New Zealand. This enormous territory had nothing whatever to do with Australia, though it had some relation to South America. This last statement is not a new one, since Beddard, Benham, Henry Woodward, Hutton, and von Ihering have all adopted, on various grounds, the view that there was some connection between $\mathrm{New}$ Zealand and southern South America (for a résumé of this subject $c f$. Suess, 4, p. 667-668). The question is, did this connection simply reach out to a previously existing Antarctic continent which had an independent connection with Australia; or was there a direct connection between New Zealand and Patagonia, independent of any connection which Australia may have had with South America? Concerning this there may be difference of opinion. In the light of more complete knowledge, it seems most reasonable to explain conditions in the simplest possible manner; this would undoubtedly be that Australia and New Zealand were connected with Patagonia by a common commissure, which may have been part of an Antarctic continent; from this continent New Zealand probably separated first, since it got few South American types compared to Australia. Antipodes, the Snares, Auckland, and the other islands lying south of New Zealand are undoubtedly remnants of this connection. There is certainly need of postulating land connections to explain the South American element in the fauna of both of these areas. The point which should be brought out most 
strongly now, and which has never been adequately touched upon, is the extreme difference between New Guinea and Australia. We notice at once that a large proportion of the anima's which have previously been cited as being common to New Guinea and Australia, though they may occur widespread through Papuasia are confined in Australia to the Cape York Peninsula region. Numberless examples of this sort of distribution are found among birds, reptiles, amphibians, and many other groups. Only one hypothesis can possibly explain this. The Cape York Peninsula of Australia formed an integral part of Papua for a long time; for almost as long it must have been cut off from the rest of Australia. The other part of the continent developed what we now know as the true Australian fauna, probably derived in great part from Antaretis; and just before the Torres Strait break took place, the region of the Cape York Peninsula became joined to the rest of Australia; thus a certain number of Australian creatures got into Papuasia, and ultimately reached the Solomon Islands on the one hand, and Celebes on the other, by the land connections which still persisted in these two directions. Thus we have an Australian element in Papuasia, but not a Papuan element in Australia, - the opposite of what Suess maintains (4, p. 668).

F. C. Muir, who has done extensive collecting in British New Guinea and in Upper Queensland, arrived independently at very similar views; with his permission I quote the following from one of his recent letters:-

"The Eucalyptus is a characteristic Australian plant, and goes into New Guinea and the Malayan Islands. But whereas in Australia it is the home of a very large and peculiar insect fauna, in New Guinea and the Malay Islands it is nearly destitute of insects. Australia is very rich in short-tongued bees. One can collect many any day; but in New Guinea and the Malayan Islands they are comparatively rare, - the Rhynchota of Fiji are far more Papuan than Australian. To anyone who has collected in British New Guinea and Queensland, the difference is very striking indeed."

Muir then continues:-

"My opinion is that the Australian fauna and flora arose in western Australia when it was separated from east Australia. In those days east Australia was a long, mountainous island, divided from west.Australia by a sea, and had a heavy rainfall. The island had then a distinct Malayan facies. When the land rose, joining east and west Australia, the east became much drier, and the western forms made headway in northern Queensland; and certain spots in southern Queensland and New South Wales, where there are still heavy rains, retain their Malayan facies; but in drier parts it is Australian. New Guinea was cut off 
(if it was ever actually joined) from Australia very early; and the great development of peculiar species of birds, insects, etc., is of later date. The real difficulty is to account for such large provinces so near to one another being so distinct, not to account for a few forms getting across the narrow passage."

Muir continues by saying that he could adduce very many facts against a recent connection between the two provinces. It is interesting to see how closely his views, based upon field observations and his studies on insects, agree with my own, based upon the studies of other animals. This two-fold origin of the present Australian fauna certainly seems reasonable enough. I can not, however, agree with Muir in believing that the connection between Papua and Queensland did not persist until after east and west Australia had joined together. That a change of climate, such as Muir suggests, would tend to destroy the Malayan fauna in southern Australia if it reduced the rainfall, is quite certain. It seems, however, more reasonable to assume that the part of Australia so long connected with New Guinea was in reality rather limited; and that some of the Malayan forms, left isolated in this region, have spread to other favorable areas in the land to which the Cape York region joined. A large proportion of Papuan species in Australia would seem, from what we know of their kindred elsewhere, to be perfectly well able to adapt themselves to somewhat changed conditions; yet they are entirely confined to this Cape York region. It is unlikely that they formerly had a great range in eastern Australia.

That Suess inclines to an opinion very like that of Muir is proved by the following quotation (4, p. 292):-

"The Cordillera [of Eastern Australia] is continued, according to Haddon, Sollas, and Cole, in islands, formed chiefly of granite, from York Peninsula across Torres Straits, and it terminates on the margin of the great southern plain of New Guinea in the granite hill of Mabudauan." He continues, "The succession of marine strata in Australia presents many more gaps in the Mesozoic series than that of Timor, New Caledonia, or New Zealand. The Cretaceous system, *** extends over broad Archaean regions; according to recent observations the desert sandstone is assigned to it."

The statement that the shallow sinking which took place to form the present Torres Straits occurred but shortly after the changes of level in Australia itself, is supported by the fact that the Solomon Islands and the New Hebrides have a strongly marked Papuan fauna, while typical Australian forms are very rare there. This is also the condition as far as New Zealand, where this connection with Papuasia and isolation from Australia is probably emphasized even by the migra- 
tions of the birds. Hutton and Drummond (Animals of New Zealand, 1905, p. 19-20) ask the question:- "Why should some of the shore birds and the two Cuckoos migrate to New Zealand, while the Swallows, which are certainly quite as capable of undertaking the journey, do not come?" Possibly the answer may be found in the palaeontological history of birds. The evidence is of a negative character, and must be used with great caution; but it seems probable that the Godwit and the Cuckoo migrated to New Zealand at a time when there were no swallows in existence, and that the original land-bridge had been completely broken down before the first of the swallows arrived in Australia from Asia. We may therefore suppose that migration to and from New Zealand commenced in the Eocene period, when the land stretched away northwest to New Guinea, a time when all New Zealand was joined to the mainland.

Papuasia, judging from its markedly peculiar bird fauna, consisting of an enormous number of species and genera, and its peculiar amphibians and insects, and especially its Onychophora, would warrant its being considered a zoölogical province almost as well differentiated as that which we have always called the Australian, and quite distinct from this. It received some characteristic Australian types from among those able to distribute themselves quickly, owing to a short-lived communication with Australia (excluding Queensland) which we have discussed. This increment has not fundamentally affected the facies of the fauna of the region.

The fauna of western Australia was received by a land connection with Asia quite independent of the Papuan-Queensland bridge, if it is necessary to suppose that Australia was ever really connected with Asia. Such a connection may have had relation to the ancient are of which Timor and Sandalwood Island are but the last remaining vestiges. These islands do not belong to the actively volcanic arc of the Lesser Sunda Islands, and have a different geologic structure. This ancient arc, too, may have led into the region of Java, and so had relation to the mainland. The islands west of Sumatra do not show evidences in their reptiles and amphibians of having formed a continuation of this arc, and of having thus formed a link between Java and the Malayan or Burmese continental region parallel to, but independent of, Sumatra. There is no hydrographic evidence of such a connection; and, though at one time it was thought that the land shells of Engaño were more like those of Java than of Sumatra, this was undoubtedly due to the fact that we then knew but little of the fauna of Sumatra, while Engaño had been visited by several collectors. Rana microdisca Boettger was formerly thought to have had a similar distribution, but it has since been found quite 
widely distributed on Sumatra. The fact that the Javan fauna came from the mainland by way of Sumatra alone, and that the Timor are would not seem to have been projected to the mainland independently of Sumatra, need not in any way effect a presumption that the Timor are may have been continuous, and had existence before the arc of the present Lesser Sunda chain came into being. The latter may have had more recent origin by extravasation and accumulation, and this may have accounted for sinking of the ancient land; and this sinking then left Timor and Sandalwood the sole remannts of what was perhaps once an ancient land-bridge from west Australia to the region where Java is now.

If Timor and Sandalwood have had this relation to both Australia and the mainland, one would expect to find on them some of what are always called the "ancient Australian types." Why these types should be supposedly so very ancient is not quite clear, for there would seem to be but few types now in existence in Australia which would require us to assign to them an origin much previous to early Tertiary times. As a matter of fact, in spite of their structure, the fauna of both of these islands is strikingly similar to that of the other islands of the Lesser Sunda chain, except for certain forms in Timor which are discussed later. There can be no doubt that they both have been joined to this chain in recent geologic time. The anomolous forms in Timor are not antique relics derived from Australia, but are rather apparently of Papuasia origin. Whether the ancestors of the characteristic Australian forms came through Sandalwood and Timor in coming from Asia, and died out there naturally; or whether they were destroyed by subsequent telluric disturbances, can never be answered. They may, on the other hand, most of them have come by way of Antaretis, perhaps even have had origin there; and in this case it is not, of course, necessary to presuppose that a continuous connection has ever existed between Australia and the continent of Asia.

The remarkable development of Ophidia proteroglypha in Australia can hardly be explained by assuming that they came from South America. The many species in Africa, and the scattered species in southern Asia, would rather lead one to suppose that these were the remnants of a once more general population of similar forms which have died out in extensive regions where they have come into contact with the more modern and successful viperine and crotaline types to which they themselves gave rise; while the proteroglyphs in Australia did not happen to evolve into these competing types as they did in other regions, and they themselves remained predominant, and form practically the whole Australian ophidian fauna. Their origin in Asia, and their probable spread from 
Asia through Australia into South America; can hardly be doubted. They have never been especially successful in South America, and only two or three species have reached to the United States. But the many prominent forms of Lachesis and Crotalus, which have come from Eurasia, have passed south, and have met their ancestral immigrants from Australia in South and Central America.

One of the points which van Kampen and previous writers have failed to emphasize is the marked difference between the faunas of the Ke and Aru Islands. This has been spoken of in detail (p.44-49) in the notes on the herpetology of these two groups of islands. We can not consider them both equally Papuan. The Ke Islands have an impoverished fauna, due largely to their small size; for the number of species supported by any island is, other things being equal, directly proportionate to that island's area; it is important to note that a number of typical Papuan types found on the Ke group extend further, and are met with either in the island of Ceram, or else more widely distributed in the Moluceas; while, on the other hand, the Aru Islands possess a larger and less differentiated number of true Papuan species, which are not found on other groups of islands. The mere presence of Draco in Ke should have suggested at once that there was a fundamental difference between the biota of the two islands.

Hartert (Nov. zool., 1901, 8, p. 2), describing a collection of birds from the Southeast Islands, - that is, those between Ceram Laut and the Ke group, - says: "Zoölogically, the Key Islands belong to the Moluccas.... Only sixty miles eastward of Dobbo in the Aru group, and just as near to New Guinea as the Aru Islands, the Key Islands have only very few specially Papuan bird forms." He continues that the Southeast Islands in general want primeval forest, and are apparently of recent, coraline nature; and that their ornis shows relations to that of Ceram and $\mathrm{Ke}$.

While dealing with the Ke Islands, it is necessary to postulate land-bridges which ha ve existed in the past, and which have left behind them entirely different sorts of hydrographic conditions. On the one hand, there are left distinct evidences of the bridge to Ceram in the shape of submerged ridges, or chains of islets connected by submarine banks; and, on the other hand, there are no submarine traces, so far as we know, of the Ke-Aru Bridge, but rather a surprisingly deep area where once the bridge probably existed. Soundings are, however, unfortunately few in this region. Such a depth near an island, and between it and the land to which it was recently joined, is not at all a rare condition. Such an island can not have been raised out of the sea, but the dividing deep 
must have been formed by subsidence. Islands presenting such deep areas all about them are simply, according to Suess (4, p. 638), great horsts, and "the theory of the permanence of oceanic basins represented by Wallace, is for this reason alone untenable." There is hydrographic evidence in the shape of extensive shoals for most of the greatly extended Papuan land which we assume existed between New Guinea and New Zealand, reaching out to and including the Fiji Islands. There are deep clefts between the Solomons and New Caledonia, but they are comparatively limited in extent. Torres Strait is so shallow as to need no comment. The deep water between Ke and Aru is remarkable, as there can be no doubt that in comparatively recent geologic times there was dry land either from Ke to Aru, or from Ke to Papua.

Mention must be made of the extremely fragmentary data which we have regarding the geology of many of the islands. This applies especially to many of the Moluccas. Suess (2, p. 171) says that the observations made on Halmahera are not sufficient to hazard even a conjecture as to the structure of the island, though regarding other islands we have a certain amount of geologic or palaeontologic information. We have spoken of the Tertiary deposit in Java, decidedly like that of the Siwalik fauna of India, which is also of late Tertiary age. No such extensive deposits have as yet been found on Borneo, though Sumatran beds are known. Mastodon, however, is known to occur on Borneo, Banka, and Sumatra, as well as on Java. If we assume that at the time of the laying down of the Javanese Tertiary beds Java was still in connection with Sumatra and the mainland, and if we also agree that Java was the first of the Greater Sunda Islands to break away from the mainland, then we see that this break must have taken place in times more recent than Tertiary. This is not a convincing argument, but it affords a working hypothesis. - From the impoverished fauna which we find upon the Lesser Sunda Islands we must assume that they were separated from Java earlier still. All are agreed to this. Celebes probably existed in about the same shape that it now has, and it also became separated from the Greater Sunda Island region at this time. We know from the researches of the Sarasins that in Eocene times Celebes was covered by the sea. Its connection with Java was Pliocene (fide Sarasins), and along this connection came most of the animals which we find in Celebes now. The existence of both a Java Bridge and a Flores Bridge from Celebes seems now to be beyond contention. We have hydrographic evidence for both bridges in the shape of chains of islands and shoals; besides there are many species of animals from Java and Celebes which do not, so far as we know, occur in the Lesser Sunda chain. Thus it would 
seem that Celebes had been in connection with Java since the Lesser Sunda chain became separated from Java, and that it was probably at the same time in connection with Flores. In this way we can account for such a distribution as that of Sphenophryne, a Papuan genus found in Celebes and Lombok, but not occurring in Java. If the Java Bridge was Pliocene, then, it would seem probable, as the Sarasins believe, that this Flores Bridge was also Pliocene; but the Lesser Sunda break with Java was surely much earlier. This interruption was between Bali and Lombok; and hence "Wallace's line" has the local significance, if nothing more. Though the Sarasins emphasize the essentially Indian character of the fauna of Celebes, still we must bear in mind that the reptiles and amphibians show extremely strong evidences of connection to the eastward.

It is futile to spend time discussing the faunistic relations of Celebes, in view of the completeness with which this has been worked out by the Sarasins. It should be noted, however, that there is good ground for emphasizing the possibility of there having been two bridges between Celebes and the Moluccas; for we know that the birds of Buru, and the presence of the Babirusa there, suggest at once a connection with Celebes; while a number of forms known from Halmahera suggest a similar connection for that island, even though there is no Babirusa on Halmahera; furthermore the birds of that island are widely different from those of Buru. On the other hand, such forms as Rana moluccana, and Typhlops ater have never been found on Buru.

It is extremely unfortunate that we do not know more about Obi. There is no evidence that would seem to justify the view that Obi was ever included, as has been suggested, in either one of these two bridges from Celebes to the Moluceas. Obi probably received its fauna by having been connected in the past with the old commissure which stretched from the southern peninsula of Halmahera to Papua. The Sula Islands would seem to have much more relation to Buru than to Halmahera, and probably represent the remains of the CelebesBuru Bridge. There is no geographic evidence whatever as to the position of the Celebes-Halmahera Bridge, unless it be that the small islands of Tifori and Majo are the remains of this old land. The water about them is very deep; but, as we have said before, this is not the only place where we must assume that land has existed where now there is deep water.

The remarkable distinctness between the faunas of Borneo and Celebes is so well known as to need no emphasis here. To return to the Moluccas, we have pointed out in our remarks on the different islands that Ceram had its connection with Papua through the Ke Islands. We were unable to explain, however, and 
can now offer no explanation for, the fact that Mysol, as has been pointed out, seems to bear a definite relation to Ceram as regards its reptiles. The birds of Mysol are strictly Papuan, and the relationship of the island to Papua is well established by the fact that it is separated by only the shallowest water. Rothschild and Hartert (Nov. zool., 1901, 8, p. 56) remark, after reporting on the ornithology of the island: "Mysol belongs faunistically entirely to New Guinea; and this is easily explained by the number of small islets stretching in a northern and northeastern direction from Mysol towards Salwatty and New Guinea, and the shallow sea surrounding Mysol and New Guinea; while deep sea, of more than 200 fathoms, separates Mysol from the Moluccan Islands. Most of the birds are quite similar to those of New Guinea; others, subspecifically allied to the latter. Moluccan influence is scarcely perceptible." Nevertheless, the strong Malayan element in the herpetology can only be explained by supposing either that there has been a land-bridge to Ceram where deep water now exists, or that we have to do with a number of erroneous records. We have not seen reports of any recent collections made in Mysol, but it hardly seems possible that so many records are invalid.

The relation of Halmahera to New Guinea has already been spoken of; and there remains now to mention the fact that Timor has a strong Australian, and perhaps a Papuasian, tinge to the fauna, which has probably not come through Timor-Laut, which lies but a little off the great shallow bank that extends out beyond the Aru Islands, from there down to Melville Island, and thence far to the southward. The fauna of Timor-Laut is different from that of Timor; therefore it seems entirely possible that while Timor-Laut may have been connected formerly with the Ke Islands, or with Papuasian land about Aru, and so indirectly with the Moluccas, Timor must have been connected directly with some old extension of Papuan land reaching westward. A connection which allowed such forms as Liasis and Chelodina to reach Timor must have been fairly recent, or perhaps have lasted for a very long time.

This whole series of suggestions may seem absurdly simple, for there can be no possible doubt that conditions were far more complicated than these conclusions would seem to presuppose. There is strong evidence of a two-fold fauna in Java. This would make it far from improbable that Java was for a long time in reality two islands, since the west Javanese fauna is in many respects strikingly different from that of east Java. Moreover climatic conditions are very different in the two ends of the island, west Java being far more heavily forested, and having a much greater annual rainfall, than east Java. Again, 
as one would expect, British New Guinea - $i$. e. that part of the island lying along the Papuan Gulf and Torres Strait - supports the great majority of the forms which are so strikingly similar to those of Queensland. The western end of New Guinea, even now almost cut off from the main bulk of the island by the Great Geelvink Bay and McCluer Gulf, has a very distinct fauna, and certainly has not always been connected with the rest of Papua. The birds of the region of Mt. Arfak are almost always specifieally, and often generically, distinct from their relatives in the Owen Stanley and Finisterre ranges. The same thing is almost equally true of the ornis of the coastal plain region. The reptiles and amphibians are strikingly dissimilar, as a glance at the table of distribution will show. Again, the question is not yet conclusively settled as to whether Celebes was pushed up from the sea as a single island with shape similar to that which it now has; or whether, as Weber holds, it has been formed by the consolidation of several separate islands, which have each received their fauna from a separate region, and these islands, having fused, gave Celebes the composite fauna which it now supports. This particular question, however, is really of no special importance. The point of real importance is the three-fold origin of the fauna itself.

The relation of the Philippines to Halmahera is a question which still awaits solution. It seems possible to project the line of recent volcanoes through Halmahera up to Mindanao; in which case land may well have existed along a similar line. Lines of recent extensive faulting often give rise to volcanoes, and this may have, been the case here. Such a connection, however, can hardly be urged as a substitute for the Celebes-Halmahera Bridge. The types which suggest immigration from Celebes do not occur among the southern Philippines, except for some on Palawan. The relation of Mindoro to Celebes, suggested at once by the distribution of the pigmy buffaloes, is, according to Bartsch, also evident from a study of the land-snails. Mindanao, with a fauna different from that of Celebes and Mindoro, must needs be of more recent origin. It has probably replaced, by having been lifted again from the sea, some of the land which became submarine between Celebes and Mindoro; and, joining with other islands, received a typical Malayan fauna from Borneo, and some Celebesian types from small islands that may have represented unsubmerged mountain peaks of the older land-mass, and that supported some of the types common to Mindoro and Celebes. The Papuan element in the amphibian fauna of Borneo may be a true relic-fauna; for the engystomatids, which exhibit such a very noteworthy elaboration in Papua, may have come from Borneo to Halmahera 
through the southern Philippines. Mindanao and Halmahera both support a number of engystomatid genera; butthese forms are not abundant in Celebes, nor, so far as we know, in the Lesser Sunda chain, where we would expect to find more of them if they got to Papua by this route. The few occurring there represent probably what is really a back-flow from Halmahera. Borneo is well known herpetologically; but these small, inconspicuous frogs are very difficult to collect, and many may yet remain undiscovered both here and in the southern Philippines. Most of the Papuan species are known by only few examples, and new forms are being discovered constantly. I have described the most recently found generic type, Pomatops valvifera Barbour, from a single example taken from the stomach of a Natrix mairii Gray. That the land-bridges by which such forms as these got from Malaya to Papuasia were narrow necks of land that probably rose steeply from the sea is suggested, as van Kampen has remarked, by the fact that the great majority of the types which were successful in extending their range to Papua are those which in their development skip the free-swimming larval period, and escape from the egg as completely metamorphosed adults. This is doubtless an adaptation to life in a land where there is little or no standing water, which was probably the condition on these narrow stretches of land. We know certainly that there is no dearth of standing water suitable for spawning places on either Borneo, Mindanao, or Papua. So far as we know, Ceram is very poor in amphibians, as are also Ambon and Buru, though of the latter we know practically nothing. So, for this reason again, it seems likely that the southern Moluccas were not in the direct route of migration of the Engystomatidae, or of the Rana varians- or R. moluccana-like form which gave rise to Rana papua in New Guinea. The connection of Ceram with Papua may have been of so narrow a form and of so transitory a nature that reptiles and birds passed across easily, but that only few amphibians came over. Again the Ceram-Ke-Papua Bridge, or the Ceram-Mysol-Papua Bridge may have existed before so many varied amphibian types became differentiated from one another by some process akin to what Osborn has called the law of adaptive radiation; or the bridges between Ceram and Papua may have already disappeared before the influx of amphibians by way of Halmahera. This is quite possible, since Mysol, which probably supports an amphibian fauna similar to that of Papua (though we know nothing of it as yet), would have lain directly in the migration route from Halmahera to Papua, and hence would have passed on these amphibians to Ceram, if a suitable bridge had existed for them to cross on. The amphibians now existing in New Guinea strike one at once as being 
peculiar in that their distribution shows no special correlation to that of the reptiles. To be sure, they have been derived from the same two directions; and the engystomatids from the Asiatic continent, which appear to have come from Borneo through the southern Philippines, and so to Papua, met there the hylids, and the single cystignathid, A phaniotis novae-guineae van Kampen, which have come from South America by way of Australia. That these amphibians have been established in New Guinea for a very long time, perhaps even since the beginning of the Tertiary, is shown by the great number of generic types which are autogenous in Papua.

With the reptiles of New Guinea we find that specific differentiation is general, but that only a few genera are entirely confined to the island. This suggests at once that the amphibians reached New Guinea long before the reptiles, and this is probably the case; though there seems no special reason to assume that the later migration of reptiles came along a different highway than that over which the ancestors of these peculiar endemic genera of amphibians had already passed. It is not necessary to assume that both reptiles and amphibians had coincident periods of maximum activity of dispersal, since there is no reason to believe that the amphibians are much more plastic, or much more subject to evolution by isolation, than are reptiles. This condition of these two groups in Papua is in marked contrast to the condition in Sumatra, for instance, an island which was long an actual part of the continent, and not a distant area connected by narrow and perhaps short-lived bridges with the most outlying region of the continental area. It seems fair to state that the amphibians of New Guinea form a very old fauna, derived even before the migration of opisthoglyphs into Australia, and certainly of much older origin than the greater part of the reptilian fauna of New Guinea itself.

The finding of Cornufer widespread from Fiji to the Philippines, as well as the development of Ranas and of Rana derivatives in the Solomon Islands, would make it appear probable that the Ranidae came to Papuasia before the Engystomatidae, or else that the latter, in spite of their adaptation to xerophilous life, spread less successfully.

Another explanation of this state of affairs which may be a solution to the question is that the Ranidae may have come from Celebes to the southern Moluccas, and so to Papua, and passed on quickly to the Solomon Islands and Fiji; while the Engystomatidae may have come through the southern Philippines to Halmahera, as has been indicated before, and, spreading more slowly, found the Bismarck, Solomon, and Fiji Archipelagos cut off from Papua before their advent. 
Mention has been made elsewhere in this paper that, broadly speaking, the number of species supported by any given island bears a direct relation to the area of the island in question. This is not an easy theory to confirm with definite data, inasmuch as two islands that appear to be geographically of about the same size may in reality be vastly different in superficial areas, according to the surface features of the country. Thus, in the West Indies, Jamaica and Porto Rico appear to be of about the same size. It is evident at once, however, that the fauna of Jamaica is vastly greater than that of the other island. It may be argued that this is due to Jamaica's being nearer to the mainland source of supply; but the fact that the whole island is traversed by high mountain ranges of broken peaks, while Porto Rico has only one or two isolated highland areas, would seem to offer the true solution of the question. So in the East Indies, taking the islands in the order of their size, the numbers of species of reptiles and amphibians are about as follows:-

$\begin{array}{lcc} & \text { Amphibia } & \text { Reptilia } \\ \text { New Guinea } & 70 & 144 \\ \text { Borneo } & 79 & 207 \\ \text { Sumatra } & 48 & 166 \\ \text { Celebes } & 26 & 83 \\ \text { Java } & 37 & 122\end{array}$

Papua and Borneo are of practically the same size. Recent accounts of surveys of them indicate that New Guinea is really the larger island. Enormous ranges of high mountains give it, of course, a vastly greater surface area. At the rate at which new species have been found in New Guinea, during the last few years, it will soon take its place at the head of the list. In Borneo, on the other hand, new species of reptiles and amphibians are now but rarely found, and our systematic knowledge of the fauna is probably approximately complete. Celebes has a larger area than Java; but, on the other hand, it has many fewer peaks, its highlands being mostly of the nature of plateaux, while in Java there are many chains composed of high peaks rising from lowland areas.' This, coupled with the fact that it is somewhat nearer the source of supply whence the fauna of Celebes has come, gives it a larger fauna than seems to be present in Celebes; though here, again, we must remember that Java is the best known island in the entire archipelago. The fact that the Ke Islands, which, zoölogically, seem to be very closely related to Ceram, have so few amphibians and so many less reptiles than Ceram is probably due to the same factor. When the Moluccas are really well explored, we shall probably find that Halmahera holds the lead it now has in point of number of species found on it; while Ceram will come next, and Buru, 
Morotai, and Obi will follow in the order named, which is the sequence in which their comparative areas place them.

The competition to which the different individuals of a species are subjected is probably of a completely different sort from that between different species; the latter sort of competition, a phenomenon of which we know little or nothing, is probably the real cause for the relation which area bears to species population.

A glance at the table of distribution, p. 169-203, will show at once that, so far as the distribution of Reptilia and Amphibia is concerned, there is no evidence whatever of the existence of what has been called a Wallace's line, a Weber's line, or any other similar faunistic boundary. To be sure, a few conspicuous forms might be chosen whose limits of distribution more or less coincided, and to this limit a "Line name" might be given. Such lines could be drawn anywhere through the whole area, and each would limit the distribution of some form or forms. Probably no species reaches from Malaya to Papua unchanged. Dibamus novae-guineae is supposed to do this now, but the identification upon which the Malay Peninsula records rest was perforce based upon the study of an immature example. A number of Malayan species do reach Halmahera, Mysol, Ceram, the Ke Islands, and Timor-Laut; and this north-south series of islands forms the only semblance of a zoölogic frontier in the region. Moluccan species of Malayan genera have reached Papua in numbers, and many other Malayan genera are represented in Papua by peculiar species. Papuan species are traceable to Celebes and Lombok. Here again that this gap is bridged is shown by the number of species which are common to Sumatra, Java, and Celebes, or to Sumatra, Java, and the Lesser Sunda chain. Thus, no line of demarcation having a fundamental significance is really existent here.

An intensive study of Ceram, Buru, the Sula Islands, and some of the Lesser Sunda Islands, both between Timor and Timor-Laut, and between Timor and Java, will be necessary before the subject can be really satisfactorily attacked. The work of the Sarasins in Celebes, and of Kükenthal in Halmahera, stand out as superb examples of what can be done; but more, far more, such work is needed.

I have tried in this paper to collect all the existing authentic data regarding the occurrence of Reptilia and Amphibia in the Archipelago, as well as to define their distribution, and, so far as possible, point out the probable origin of the herpetologic fauna of each island. The task has been aided by a knowledge of geographic conditions which only a voyage through the Archipelago can give; nevertheless no one can realize more fully than I how inadequate has been my treatment of a most absorbing subject. 


\section{SUMMARY.}

The following conclusions seem warranted by the evidence obtained. It is to be emphasized that these conclusions are based primarily on herpetologic evidence only.

1. The fauna of the three Greater Sunda Islands, Sumatra, Borneo, and Java, has been entirely derived from the Malay Peninsula region. The supposed Papuasian element in the Javan fauna, which has been emphasized by Werner, is probably entirely non-existent.

2. The islands off the western coast of Sumatra have probably not formed an ancient highway whereby the migration of animals once took place between Java and the mainland, but have rather formed a part of three great peninsulas which jutted out to the westward from Sumatra, and along which they received the fauna which they support. This explanation is proposed in place of the one previously suggested, that each island received its animal population from that part of Sumatra which was nearest to it in point of distance

3. The relation of Celebes to the regions lying eastward suggest that there have been two bridges between Celebes and the Moluccas.

4. The evidence is not conclusive that Obi ever had direct relationship with Celebes or either of the Celebes-Molucca Bridges. The soundings suggest that it may have received its fauna by having been joined to the old commissure which stretched from southeastern Halmahera to Papua.

5. Mysol supports a most anomalous fauna, if the records for the occurrences of species on this island can all be believed. The reptiles seem to show a marked relationship with those of Ceram and the southern Moluccas, though hydrographically the islands seem to be intimately related to Papua only, while the mammalian and avi faunas are both evidently purely Papuan.

6. The distribution of the genus Casuarius among flightless birds is paralleled by that of Acanthophis, and by that of certain burrowing skinks; so that Ceram seems to be connected with Papua more intimately and more recently than any other of the Moluccas. This connection was probably by way of the Southwest and $\mathrm{Ke}$ Island groups.

7. The Ke Islands should not be considered equally with the Aru Islands as having a Papuan fauna. The conditions in the two groups are fundamentally different, and the creatures which they support show that the Ke Islands have had direct relations with the Moluccas which the Aru Islands have not had, hence their fauna is much more Malaysian in character. 
8. Apparently the Papuasian fauna, taken as a whole, is sufficiently well differentiated to be considered as an entity almost as distinct as that which has always been called the typically Australian fauna. This is shown by the conditions seen amongst a number of groups of animals. There is also evidence of a distinct fauna in western Dutch New Guinea, which may have been separated from eastern Papua during part of the time that eastern Papua was one with northern Queensland.

9. The manifold origin of the fauna of Australia seems worthy of emphasis. That the cystignathids and hylids, among amphibians, came from South America seems to be almost beyond contention; while other groups suggest an Asiatic derivation. The assumption that in western Australia the many characteristic Australian types were evolved while this region was separated from Queensland, and while the latter was in connection with New Guinea, seems to be the only satisfactory explanation of the fact that there is so strong a Papuasian element in the fauna of Queensland, and that so many of the autocthonous Australian genera are absent from New Guinea.

10. Broadly speaking, flotsam and jetsam methods of dispersal have played a negligible part in providing any of the islands under discussion with the fauna which they now support, although in some cases species carried by human agency have circulated widely.

11. There is evidence, though as yet it is of an unsatisfactory and fragmentary nature, that the species population of an island has a very direct relation with the surface area of that island, other things being equal. It would not be possible, however, to compare in this way the faunas of two islands having the same size if one of them had a heavy rainfall and luxuriant vegetation, while the other was arid.

The evidence which would show that any existing island has remained unchanged faunally since the time when it formed a part of the land-bridge between Australia (not Queensland) and continental Asia is apparently altogether wanting. The geologic formation of Timor and Sandalwood (or Sumba Island) would lead one to suppose that these islands might be the remains of an ancient synclinal arc which curved from Australia toward the mainland. The zoölogic evidence is unsatisfactory, although Timor supports a number of species which are in marked contrast to those found throughout the Lesser Sunda Island chain.

13. Neither Wallace's nor any other line can be held to form a real zoölogical boundary. A transition zone with a fairly definite western frontier and with an eastern frontier incapable of equally clear definition seems really to be 
the condition which serves to separate the Malayan from the Papuasian subregions. This zone may be about equally well defined for any of the groups of land animals, and the boundaries for the distribution of the several groups coincide with reasonable accuracy.

\section{POSTSCRIPT.}

Since this paper was written several reports upon the herpetology of the East Indies have been received. The records for these new species and new localities have been added to the table of distribution. These additions have naturally made differences, in some cases, regarding what is said in the body of this work regarding the number of autocthonous species in the various islands, and the range of distribution for some other species. It was thought best, however, to bring the information in the table as nearly down to date as possible. Every effort has been made to have them complete and accurate. The writer begs that readers noting errors and omissions will communicate them to him, as it is hoped to republish the table from time to time.

The reports recently received are those of Nelly de Rooy (Nova Guinea, 1909, 5, livr. 3, p. 375-383, pl. 17-18), and two by T. W. van Lidth de Jeude, (Nova Guinea, 1911, 5, livr. 4, 1911, p. 519-530, and 9, livr. 2, p. 265-287, pl. 8). These reports are all upon the rich booty of the various recent expeditions which have been exploring Netherland's Papua under the auspices of the Dutch government and scientific societies. Many important new species are described, and the ranges of many other known species from Malaysia, Queensland, and even the Philippines, have been extended to include Papua.

Besides these purely herpetological reports, another has appeared by Max Weber, "Die fische der Aru- und Kei-Inseln. Ein beitrag zur zoogeographie dieser inseln." Abh. Senck. naturf. ges., Frankfurt, A. M., 1911, 34, p. 3-49, taf. 1-2. This analyzes very carefully the fish faunas of these two groups, with special reference to those forms which are known to be absolutely confined to fresh-water. Weber's conclusions are summed up in the closing sentence of his remarks upon the zoögeography of the island. "Wohl aber dürfen wir nach dem vorliegeden Materiale schliessen, dass die Süsswasserfische von Hoch-Kei durchaus indischen Charakters sind und ganz verscheiden von denen der AruInseln, welche letztere einen ausgesprochen australischen (papuanischen) Charakter besitzen." This substantiates what is stated earlier in this paper regarding the difference in the faunas of these two groups, when it was pointed out that there was a great difference in the reptilian and amphibian faunae of 
the two groups. The Ke Islands support many forms which have passed from Papua to the Moluccas, while the Aru Islands, probably geologically much younger, support few species which Papua has in common with the other islands, Ceram for instance.

Still more recently Fry (Rec. Aust. mus., 1912, 9, p. 87-106, pl. 8-9) has described several species of a new engystomatid genus, Austrochaperina, from Queensland. This most important discovery emphasizes what has already been said about the Papuan element in the Queensland fauna. A feature so prominent as to demark this region sharply from the rest of Australia and to really permit of our considering Queensland as practically a zoölogic dependency of Papua.

At the last moment, after this paper was in page proof, I received from Dr. Boulenger a notice entitled "On some tree-frogs allied to Hyla caerulea." (Zool. jahrb. Suppl., 1912, 15, 1, p. 211-218). This affects one species which is referred to frequently and others less often mentioned. Hyla dolichopsis (Cope) becomes a synonym of Hyla infrafrenata (Günther). The latter was described from a young Australian example and the former from a Moluccan adult. Dr. Boulenger forestalls what I have said regarding the characters of the variety tenuigranulata Boettger; this form can not be recognized. The other variety, pollicaris, described by Werner is a synonym of the valid species Hyla militaria Ramsay, the type of which also came from New Britain. Hyla aruensis Horst becomes a synonym of Hyla infrafrenata (Günther) so that its anomalous distribution, Aru Islands and Mysol, is quite insignificant. Dr. Boulenger also relegates van Kampen's Hyla sanguinolenta to the same category. Two new species are described Hyla spengeli and Hyla humeralis, the former is described from a single female and the latter from two males. Both forms are very close to, if really distinct from, Hyla infrafrenata. A long and most interesting table of measurements of specimens of Hyla caerulea and $\mathrm{H}$. infrafrenata is also contained in the paper and the series shows that the former, usually considered an Australian species pure and simple, occurs in the Owen Stanley Mountain range of British Papua along with its near ally, Hyla infrafrenata. 


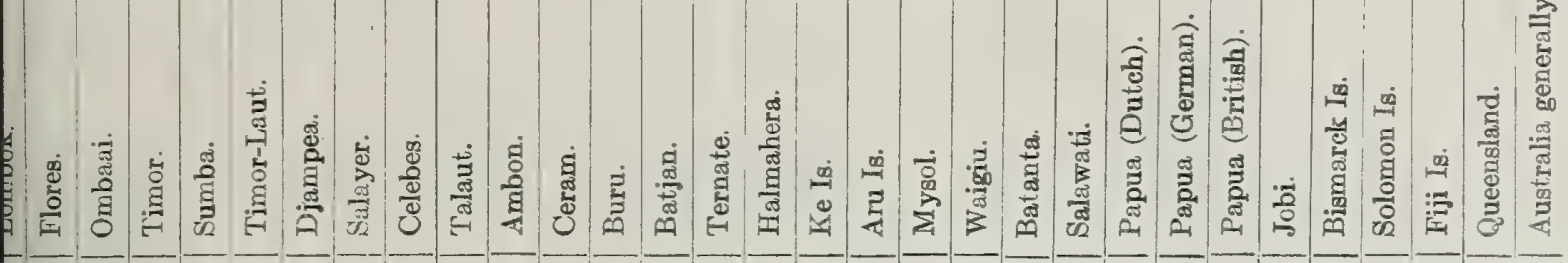

$\times$

$\dot{x}$

$x$
$x$
$x$

$x$

$x$
$x$

$x$

$x$

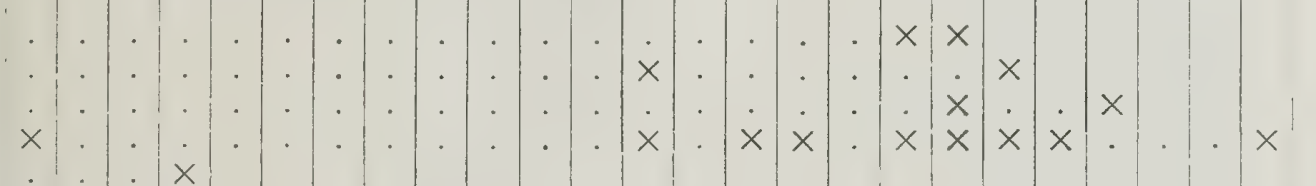

$\left.\begin{array}{c}x \\ x \\ \dot{x}\end{array}\right] \cdot \cdot \cdot x \times x$

$\mid \begin{aligned} & x \\ & x \\ & x\end{aligned}$

$\times$

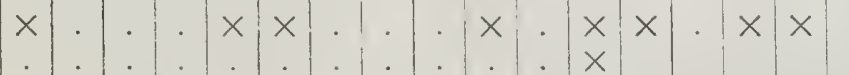


1 
Oxyglossus lima Tschudi Oxyglossus laevis Günther

Rana kublii Dum. \& Bibr.

Rans grunniens Daudin.

Rans modesta Boulenger

Rana microtympanum van Kampen

Rana leytensis Boettger

Rana microdisca Boettger

Rana palavacensis Boulenger

Rana hascheana (Stoliczka)

Rana limnocharis Wiegm

Rana arfaki Meyer

Rana macroscelis Boulenger

Rana novae-brittanis

Rana celebensis Peters

Rana varians Boulenge

Rana moluccana Boettger

Rana erythraea Schlegel

Rana nicobariensis (Stoliczka)

Rana javanica Horst

Rana chalconota Schlegel

Rana everetti Boulenge

Rana labialis Boulenger

Rana macrops Boulenge

Rana jerboa Günther

Rans whiteheadi Boulenge

Rana hosii Boulenger

Rana cavitympanum Boulenger

Rana guttata (Günther)

Rana luctuosa (Peters)

Rana signata (Günther)

Rana mackloti Schlegel

Rana glandulosa Boulenge

Rans baramica Boettger

Rana pantherina van Kampe

Rana debuobyi van Kanper

Rana novre-guineae

Rana opisthodon

Cornufer corrugatus (A. Dumeril)

Cornufer unicolor Tschudi

Cornention

Cornufer boulengeri Boettger

Cornufer guppyi Boulenger

Cornufer solomonis Boulenger

Cornufer punctatus Peters \& Doria

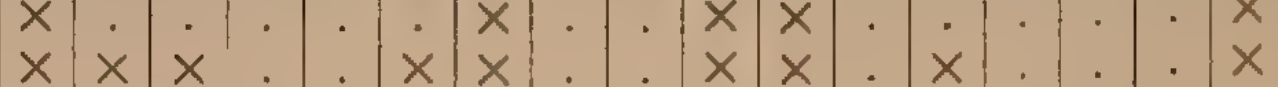

$x . x \times x \times x . . .8$.

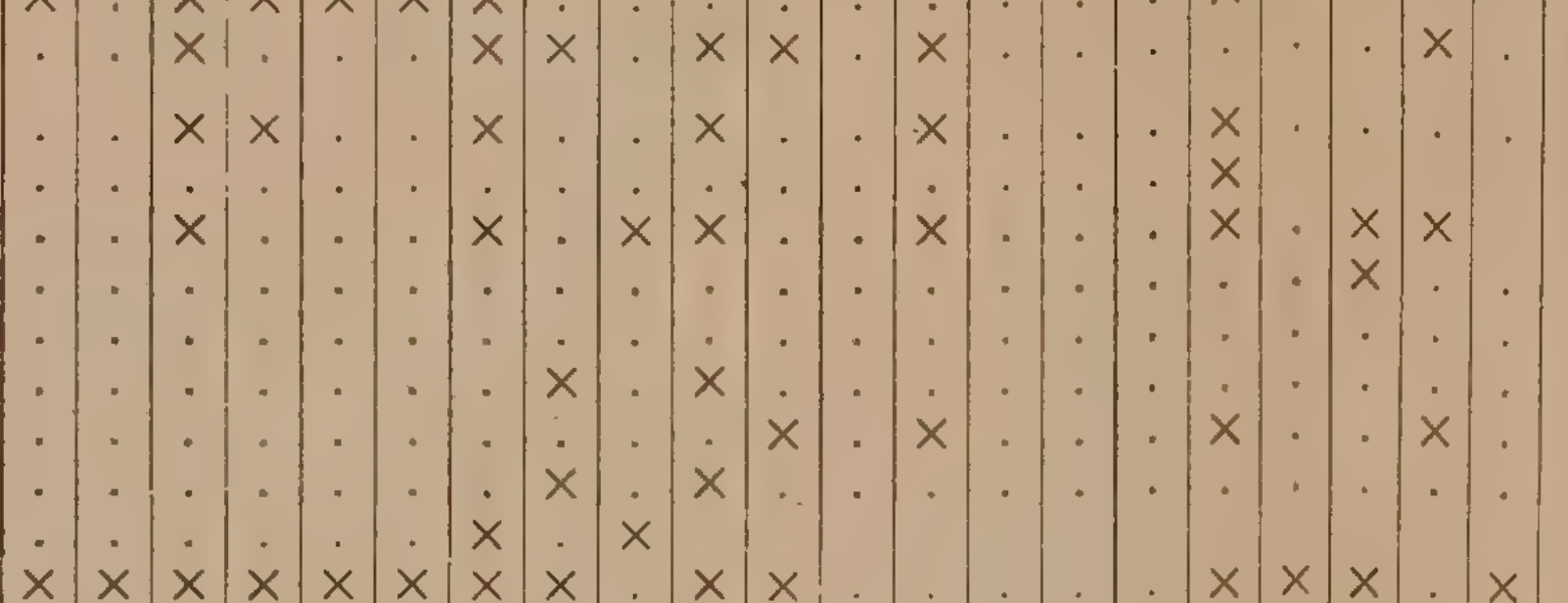

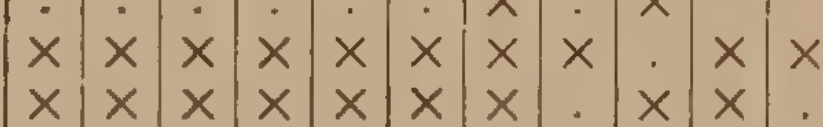

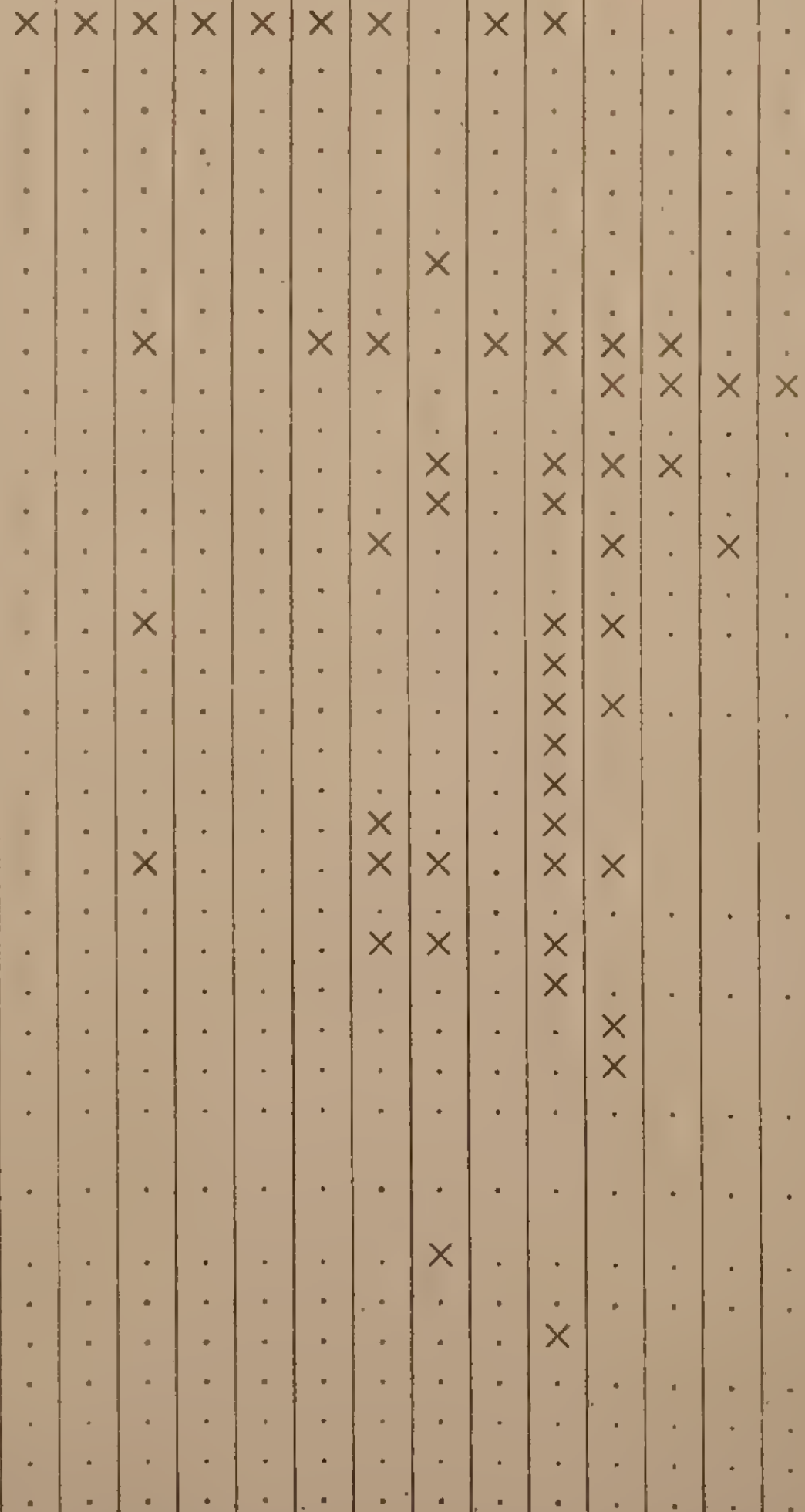

"Wetter Island. 
BARBOUR: ZOÖGEOGRAPHY.

Ichthyophis monochrous (Bleeker) Ichthyophis glutinosus (Linné)

Oxyglossus lima Tschudi Oxyglossus laevis Günther

Rana kuhlii Dum. \& Bibr.

Rana grunniens Daudin.

Rana macrodon Dum. \& Bibr.

Rana modesta Boulenger

Rana microtympanum van Kampen

Rana leytensis Boettger

Rana microdisca Boettger

Rana palavacensis Boulenger

Rana hascheana (Stoliczka)

Rana tigerina Daudin

Rana limnocharis Wiegm.

Rana arfaki Meyer

Rana macroscelis Boulenger

Rana novae-brittaniae Werner

Rana papua Lesson

Rana celebensis Peters

Rana varians Boulenger

Rana moluccana Boettger

Rana erythraea Schlegel

Rana nicobariensis (Stoliczka)

Rana javanica Horst

Rana chalconota Schlegel

Rana everetti Boulenger

Rana labialis Boulenger

Rana macrops Boulenger

Rana jerboa Günther

Rana whiteheadi Boulenger

Rana hosii Boulenger

Rana cavitympanum Boulenger

Rana guttata (Günther)

Rana luctuosa (Peters)

Rana signata (Günther)

Rana mackloti Schlegel

Rana glandulosa Boulenger

Rana baramica Boettger

Rana pantherina van Kampen

Rana debussyi van Kampen

Rana novae-guineae van Kampen

Rana elberti Roux ${ }^{1}$

Rana opisthodon

Cornufer corrugatus (A. Dumeril)

Cornufer unicolor Tschudi

Cornufer baluensis Boulenger

Cornufer boulengeri Boettger

Cornufer guppyi Boulenger

Cornufer solomonis Boulenger

Cornufer punctatus Peters \& Doria

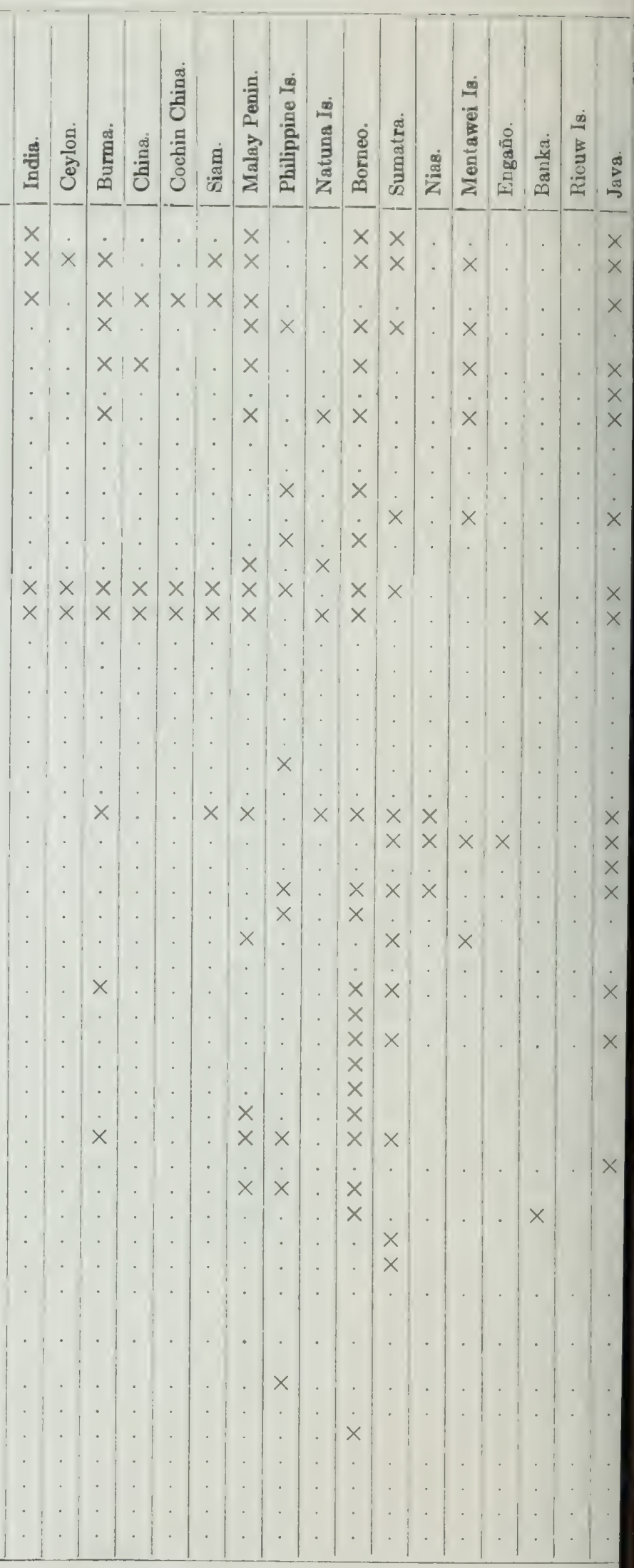

Wetter Island. 




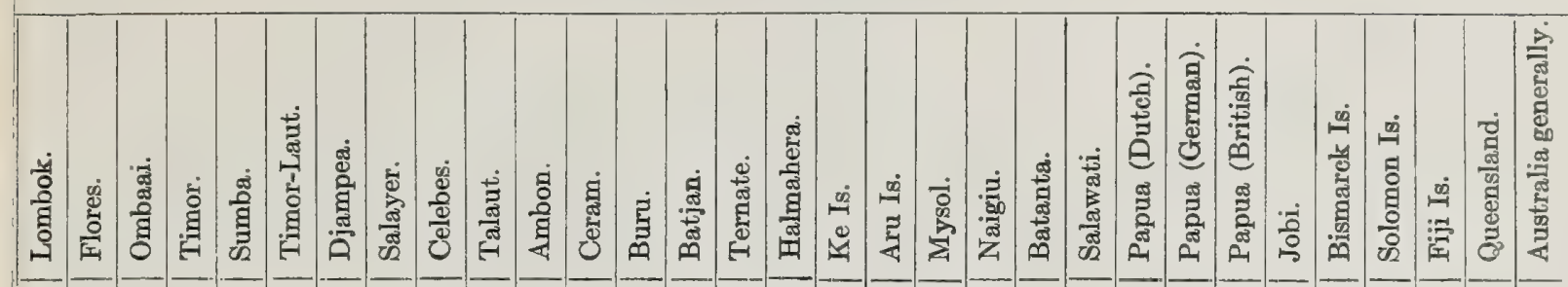

$\times x . \times x \cdot x$

$. \quad . \quad . \quad . \quad . \quad . \quad \frac{x}{x}$

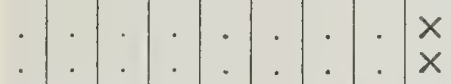



AMPHIBIA

Oreobatrachus baluensis Boulenge

Polypedates leprosus (Schlegel) Polypedates leucomystax (Gravenhorst) Polypedates macrotis (Boulenger) (Bougen (Polypedates macreser) Polypedates mascelis (Boulenger) Polypedates edentulus (F. Müll

Polypedates appendiculatus Günther Polypedates javanus (Boettger) Polypedates acutirostris (Mocquard) Polypedates monticola (Boulenger) Polypedates georgii (Roux)

Polypedates pulchellus (Werner)

Polypedates pardalis (Günther)

Polypedates shelfordi (Boulenger)

Polypedates fasciatus (Boulenger)

Polypedates dulitensis (Boulenger)

Polypedates reinwardti (Wagler)

Polypedates nigropalmatus (Boulenger)

Polypedates chiropterus (Werner)

Polypedates liber (Peracea)

Philautus flavosignatus (Boettger)

Philautus pictus (Peters)

Philautus petersi (Boulenger)

Philautus aurifasciatus (Schlegel)

Philautus vittiger (Boulenger)

Philautus bimaculatus

Philautus latopalmatus (Boulenger)

Philautus palidipes (Barbour)

Nyctixalus margaritifer Boulenger

Mantophryne lateralis Boulenge Mantophryne microtis Werner

Gnathophryne robusta (Boulenger) Gnathophryne boettgeri Méhely Gnathophryne dubia (Bttgr.)

Xenorhina oxycephala (Schlegel) Xenorhina atra Günther

Xenorhina rostrata (Méhely)

Xenorhina bidens van Kampen

Metapostira ocellata Méhely Metapostira macra van Kampe

Copiula oxyrhina (Boulenger)

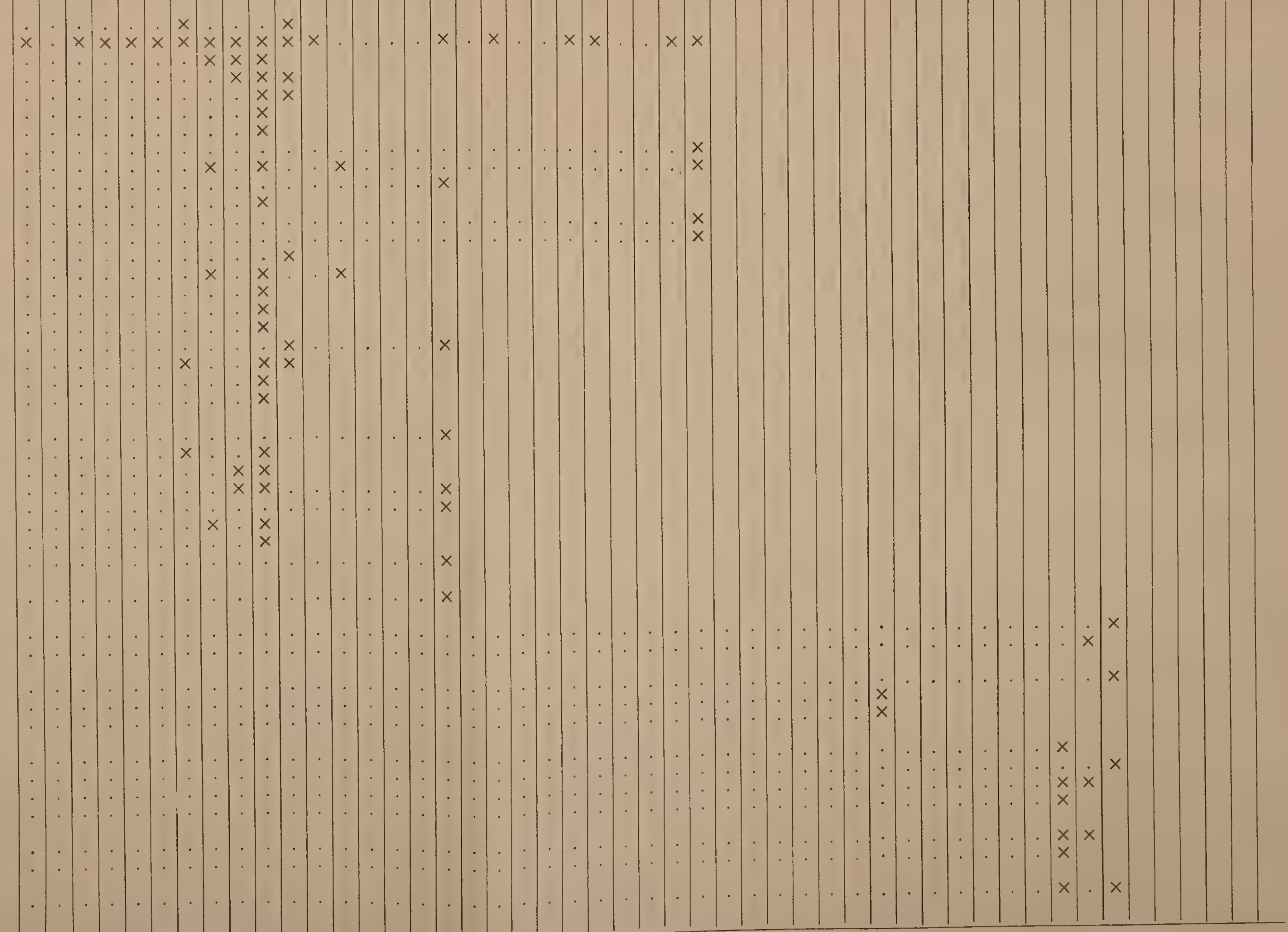





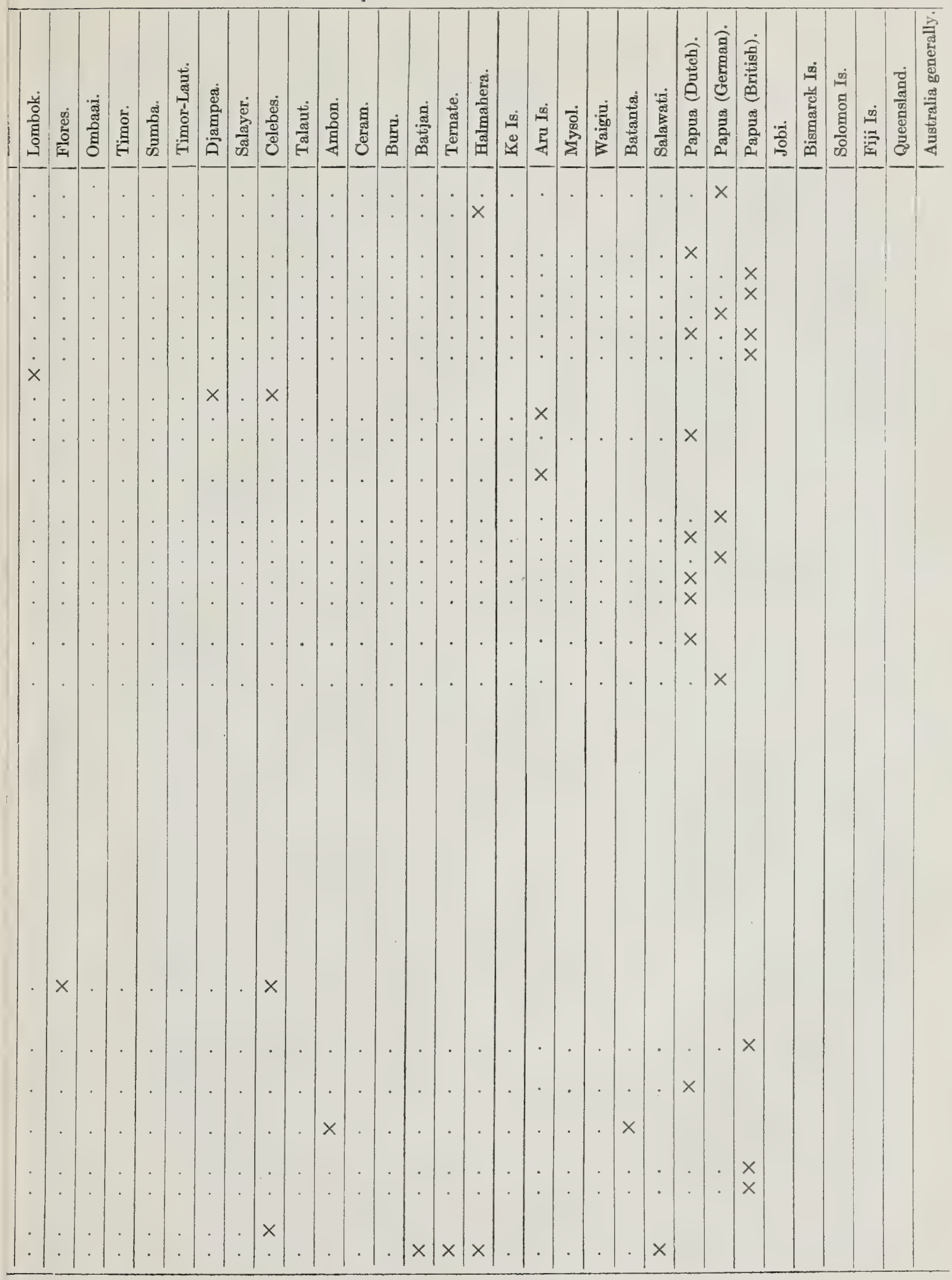




$$
1
$$


Phrynizalus birsi Méhely

Phrynizalus montanus Boettger

Sphenophryne cornuta Peters \& Doria Sphenophryne anthonyi Boulenge Sphenophryne atelea Boulenger Sphenophryne biroi Méhely Sphenophryne lorize Boulenger Sphenophryne verrucosa Boulenger Sphenophryne monticols Bouleager Sphecophrne variabili Bouleger Sphenophryne albopunctata van Kampen

Microbatrachus pusillus Roux

Chapering fusca Mocquard

Chsperins imscrorhyncha van Kampen Chaperins polysticts Méhely

Chaperina basipalmata van Kampen

Chaperins ceratophthalmus van Kampen

Pomatope valvifers Barbour

Cophiralus geislerorum Boettger

Phrynells pulchra Boulenger

Engystoms borneense Boulenger

Mierohyla inornsta Boulenger Microhyla bungurana (Günther) Microhyle achatins (Boie) Microhyls leucostigms Boulenger Microhyls palmipes Boulenger Microhyla annectens Boulenger Mierobyla berdmorii (Blyth)

Kalouls balests (Müller) Kaloula pulchra Gray Kaloula sundana (Peters)

Callulops dorize Boulenger

Xenobatrachus ophiodon Peters \& Doria

Phrynomantis fusce Peters

Liophryne brevipes Boulenger Liophryne brododactyla Boulenger

Ureophryne celebenais F. Müller

Oreoplry

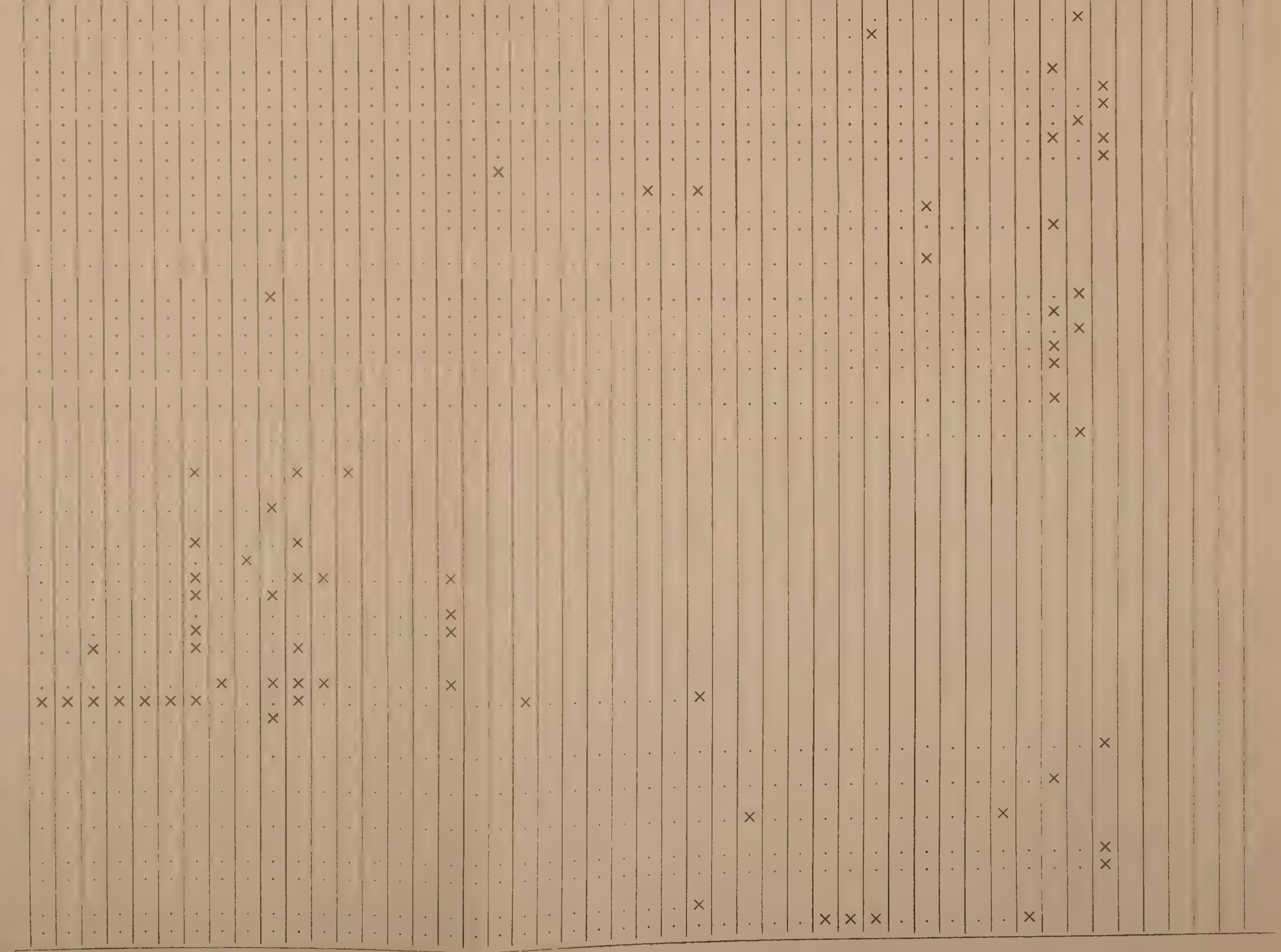





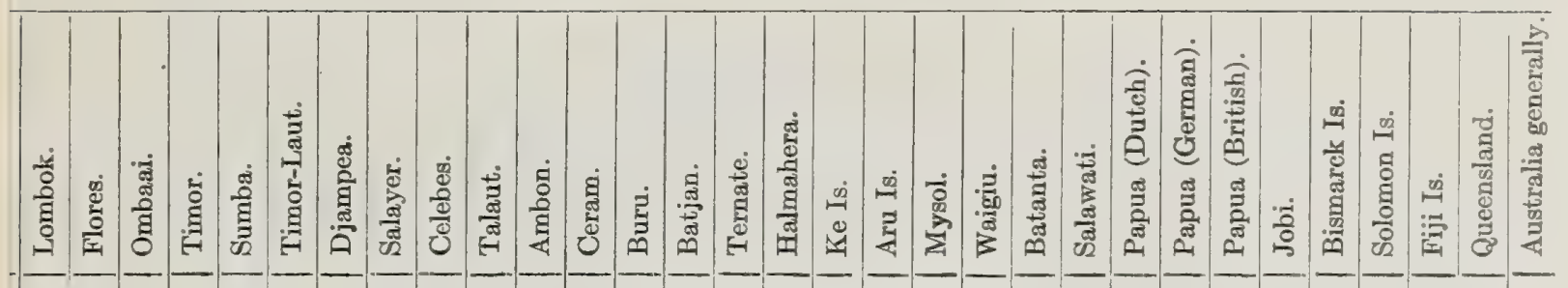

$\mathrm{x}$
$\mathrm{x}$

$\times$. . . . . . . . $\times$

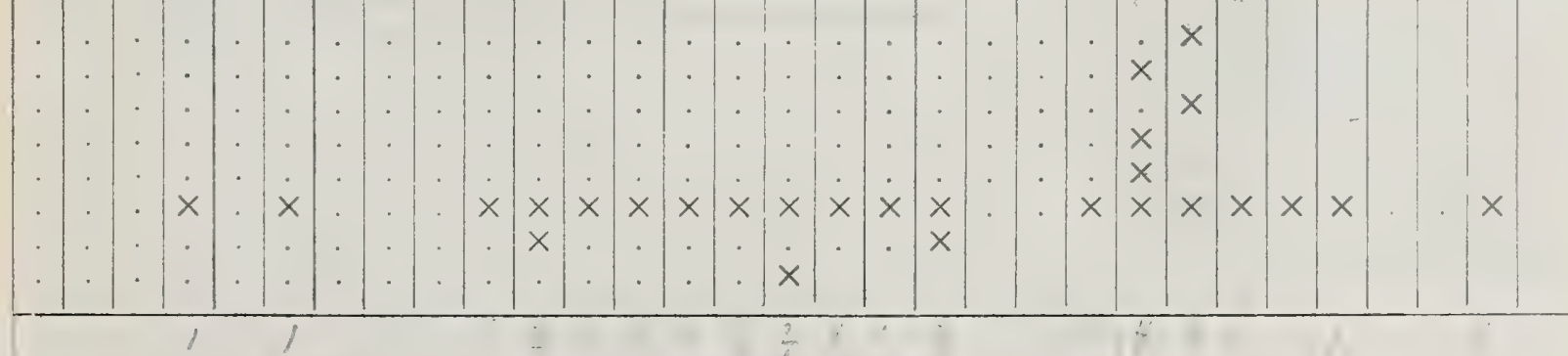




$$
L
$$


AMPHIBIA

Calophrynus pleurostigma Tschudi hirus Boulenge

Genyophryne thomsoni Boulenger

Phanerotis novae-guineae van Kampen

Colpoglossus brooksi Boulenger

Dyscophina volgi van Kampen

Nectophryne everetti Boulenger Nectophryne exigua Boettger Nectophryne guentheri Bouleng Nectophryne hosi Boulenger Nectophryne macotis Boulenger Nectophryne maculata Mocquard Nectophryne misera Mocquard Nectophryne signata Bowlenger n Kampen

Bufo borbonicus (Boie) Bufo cruentgtus Tschud Bufo leptopus Günthe

Bufo jerboa Boulenger

Bufo fullgineus Mocquard

Buro penangensis (Stolicaka)

Bufo sumatranus Peters

Bufo spinulier Mocquard

Bufo melanostictus Schneide

Bufo biporcatus Tschudi

Bufo cavator Barbour

Bufo quadriporcatus Boulenger

Bufo parvus Boulenger

Bufo claviger Peters

Buro divergens Peters

Bufo longieristatus Wern

Bufo asper Gravenhorst

Nectes subasper (Tschudi)

Nectes pleurotsenis van Kampen

Nectes pleurotaenis van Kam

Hyla eucnemis Lönnberg
Hyla rhacophorus van Kampen

Hyla rhacophorus van Ka

Hyla papuensis Werner

Hyla papua van Kampen.....

Hyla sanguineolenta van
Hyla dolichopsis (Cope)

Hyla amboinensis Hor

Hyla ruepelli Boettger

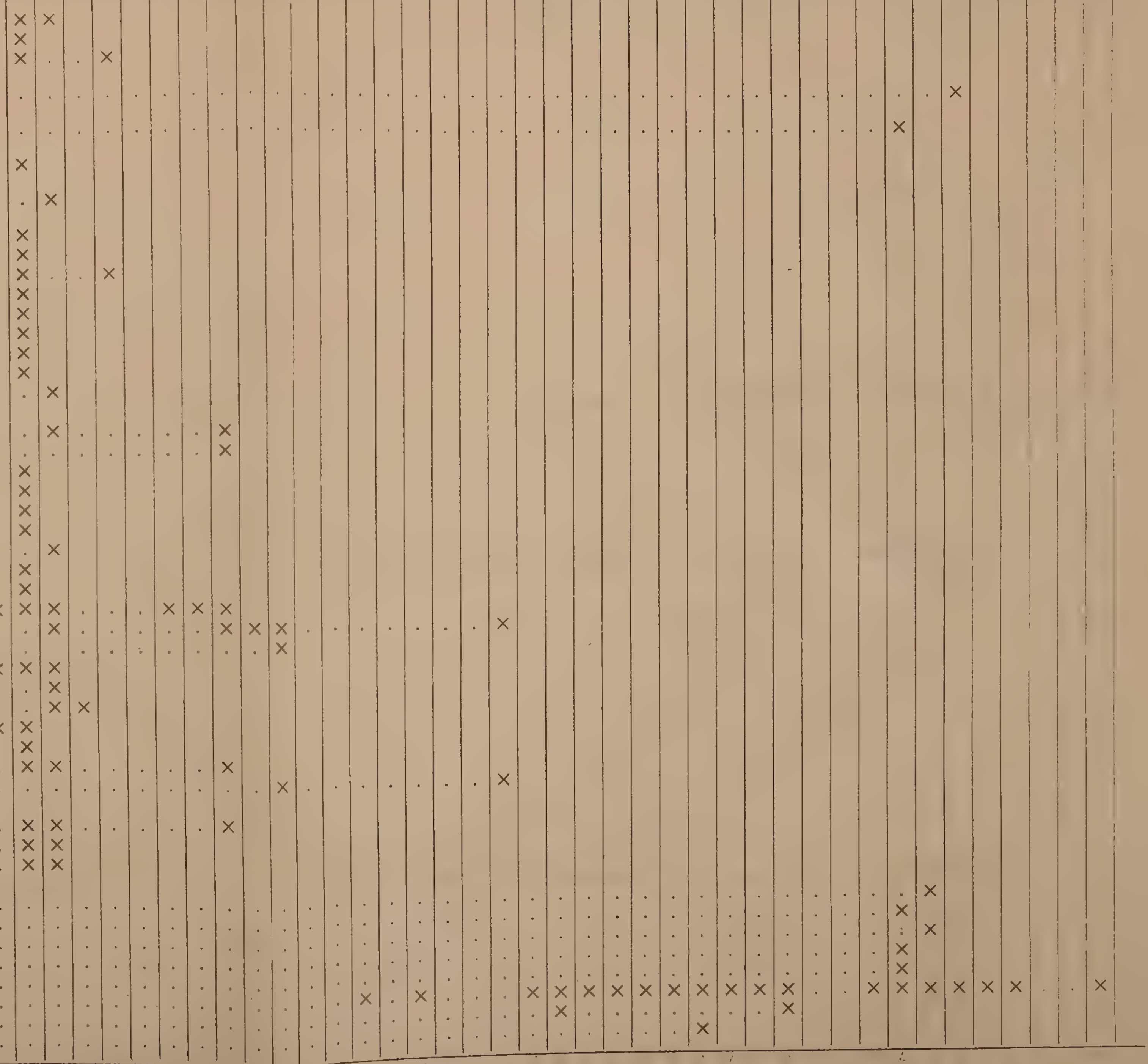





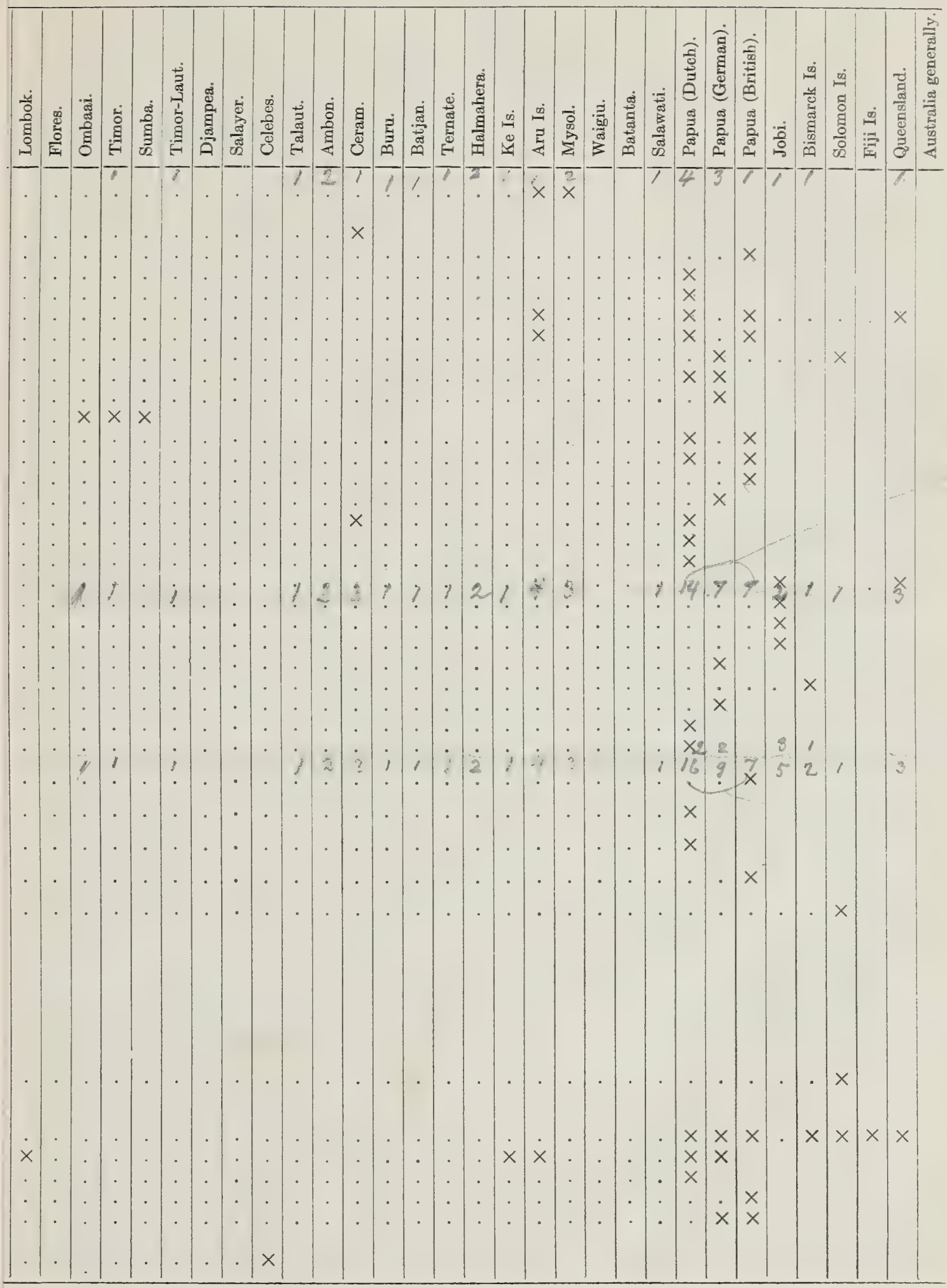


Ampribia.

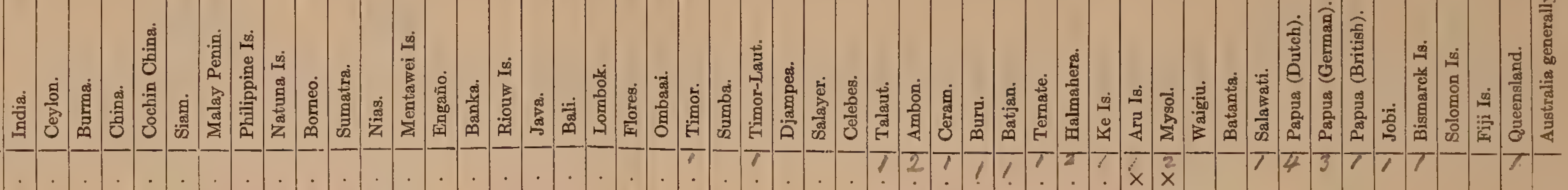

Hyla aruensis Horst
Hyla genimaculata Horst Hyla kampeni Barbour Hyla macrib Hyla montan Peters \& Doria Hyla myste Hyla bicolor Gray Hyla congenita Peters \& Doria Hyla thesaurensis Peters Hyla boulengeri Méhely Hyla jeudii Werner

Hyla everetti Boulenge Hyla impura Peters \& Doris Hyla nasuta Gray

Hyla semoni Boettger

Hyla obsoleta Lönnberg Hyla vagabunda Peters \& Doria Hyla arfakiana Peters \& Dora Hyla prattii Boulenger

Hyla obtusirostris Meyer
Hyla (Hylella) ouwensi Barbour Hyla (Hylella) nigropunctata Meye Hyla (Hylella) pygmea Meyer Hyla (Hylella) wolterstorferi Werner Hyla (Hylella) brachypus (Weraer) Hyla (Hylella) bonlang Hyla (Hylella) chloronota Boulenge Nyctimantis papua Boulenger Lechriodus melanopyga Doria Asterophrys turpicola Müller Ranaster convexiusculus Macleay Batrachylodes vertebralis Boulenger Megalophrys gracilis (Günther) Megalophrys natunae (Günther) Megalophrys baluensis (Boulenger) Megalophrys hasselti (Tschud) Megalophrys nasuta (Schlegel) Megalophrys montana Wagler Ceratobatrachus guentheri Boulenger SaURIA.

Gymnodactylus pelagicus (Girard) Gymnodactylus marmoratus Dum. \& Bibr. Gymnodactylus consobrinus Peters Gymnodactylus loriae Boulenger Gymnodactylus louisiadensis De Vi Gymnodactylus lateralis Werner Gymnodactylus jellesmae Boulenge 



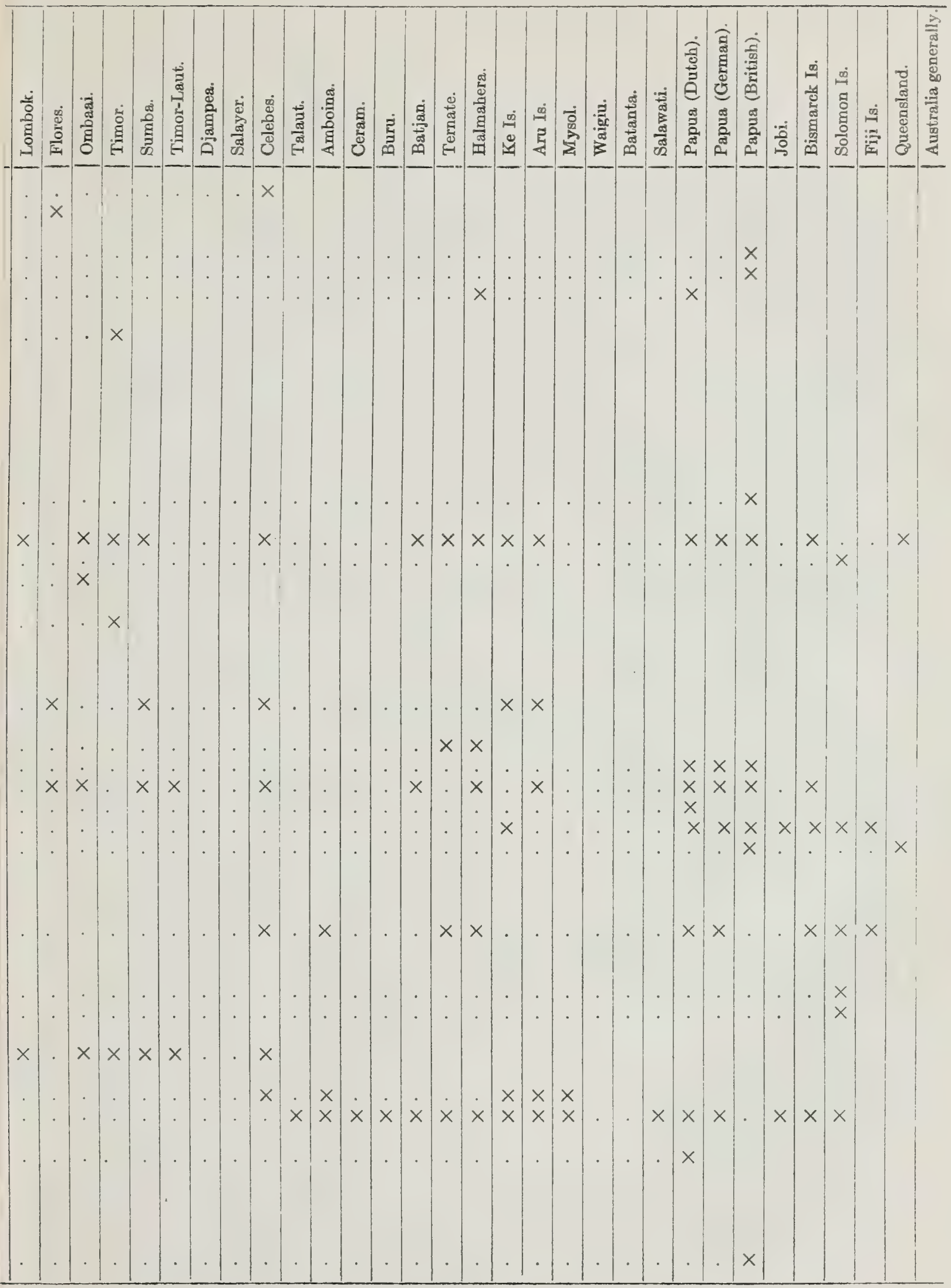


Gymnodactylus fumosus F. Müller Gymnodactylus darmandvillei M. Webe Gymnodactylus baluensis Mocquard Gymnodactylus heteronotus Boulenge Gymnodactylus cheverti Boulenger Gymnodactylus philippinicus Steind.

Gonatodes timorensis Dum. et Bibr. Gonatodes kendallii Gray Gonatodes affinis (Stoliczka) Gonatodes kandianus Kelaart

Aeluroscalabotes felinus (Günther) Aelurosealabotes dorsalis (Peters)

Thecadactylus australis Günther

Hemidactylus frenatus Dum. \& Bibr. Hemidactylus garnotii Dum. \& Bibr. Hemidactylus brookii Gray Lidth de Jeude Hemidactylus tenkatei van Lidth de Jeude

Mimetozoon craspedotus (Mocquard)

Cosymbotus platyurus (Schneider)

Peropus marginatus (Boulenger) Peropus interstitialis (Oudemans) Peropus mutilatus (Weigmann) Peropus baliolus (A. Dumeril) Peropus oceanicus (Lesson) Peropus variegatus (Dum. \& Bibr.)

Spathoscalabotes mutilatus (Gthr.)

Lepidodactylus lugubris (Dum. \& Bibr.) Lepidodactylus ceylonensis Boulenger Lepidodactylus aurantiacus (Beddome) Lepidodactylus guppyi Boulenger Lepidodactylus woodfordii Boulenge

Gekko gecko (Linné)

Gekko stentor (Cantor)

Gekko monarchus (Dum. \& Bibr.)

Gekko vittatus Houttuyn

Gekko rhacophorus Bouleng

Gekko pumilus Boulenger

Ptychozoon kuhlii Stejneger Ptychozoon horsfieldii (Gray)

Lialia jicari Boulenger

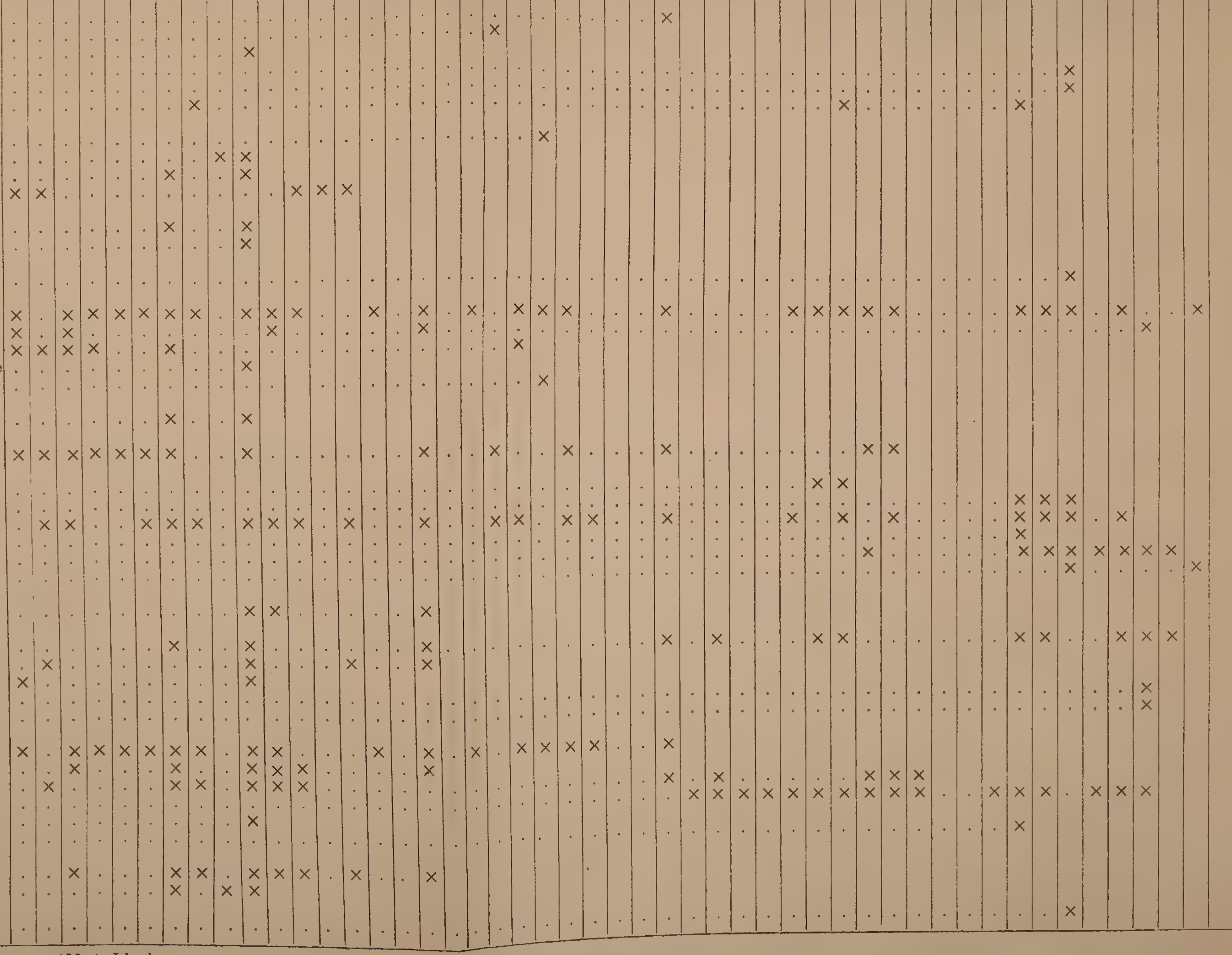

${ }^{1}$ Morty Island. 



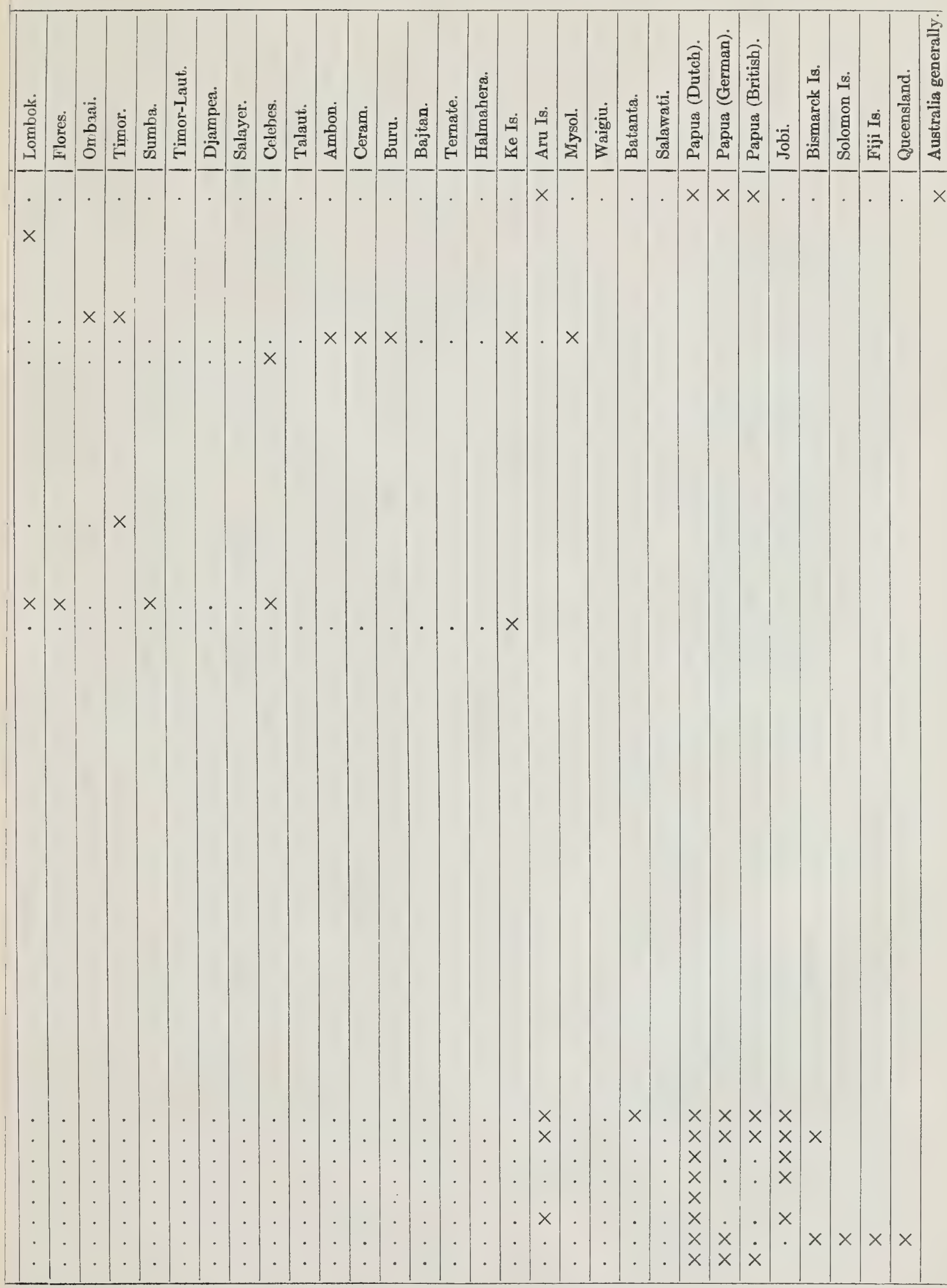


Satria.

量

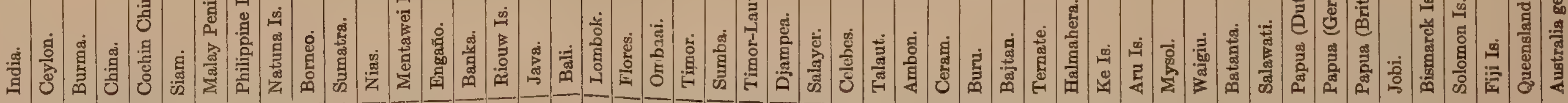

Lialis boutonii Gray

Draco volans Linne

Draco cornutus Günthe

Draco gracilis Barbour

Draco rostratus Günth

Dreco lineatus Daudin

Draco beccarii Peters \& Doria

Draco fimbriatus Kuhl

Draco haematopogon Gray

Draco melanopogon Boulenger

Draco affinis Bartlett

Draco maximus Boulenger

Draco micropis Boulen

Draco micher

Draco modkglianii Vincigu

Draco walkeri Boulenger

Draco taeniopterus Gunther

Draco quinquefasciatus $\mathrm{Gray}$

Draco reticulatus Günthe

Draco ochropterus Werner

Draco foroposs Boulenger

Droo intermedius Werne

Aphaniotis fusca Peterø

Aphaniotis acutirostris Modigliani

Lophocalotes leudekingii (Bleeker)

Cophotis sumatrana Hubrecht

Harpesaurus tricinctus (A. Dum.)

Harpesaurus beccarii Doria

Phoxophrys tuberculata Hubrecht

Gonyocephalus megalepis (Bleeker)

Gonyocephalus doriae Peters

Gonyocephalus chamaeleontinus (Laurenti)

$=C_{\text {Gonyocephalus kuhlii Schlege }}$

Gonyocephalus sumatranus (Schlege)

Gonyocephalus liagaster (Günther)

Gonyocephalus miotympanum (Gthr.)

Gonyocephalus borneensis (Schlegel)

Gonyocephalus dilophus (Dum. \& Bibr.)

Gonyocephalus modestus Meyer

Gonyocephalus geelvinkianus Ptrs. \& Doria

Gonyocephalus auritus Meyer

Gonyocephalus bruijnii Ptrs. \& Doria

Gonyocephalus binotatus Meyer

Gonyocephalus godeffroyi Peters

Gonyocephalus papuensis Macleay

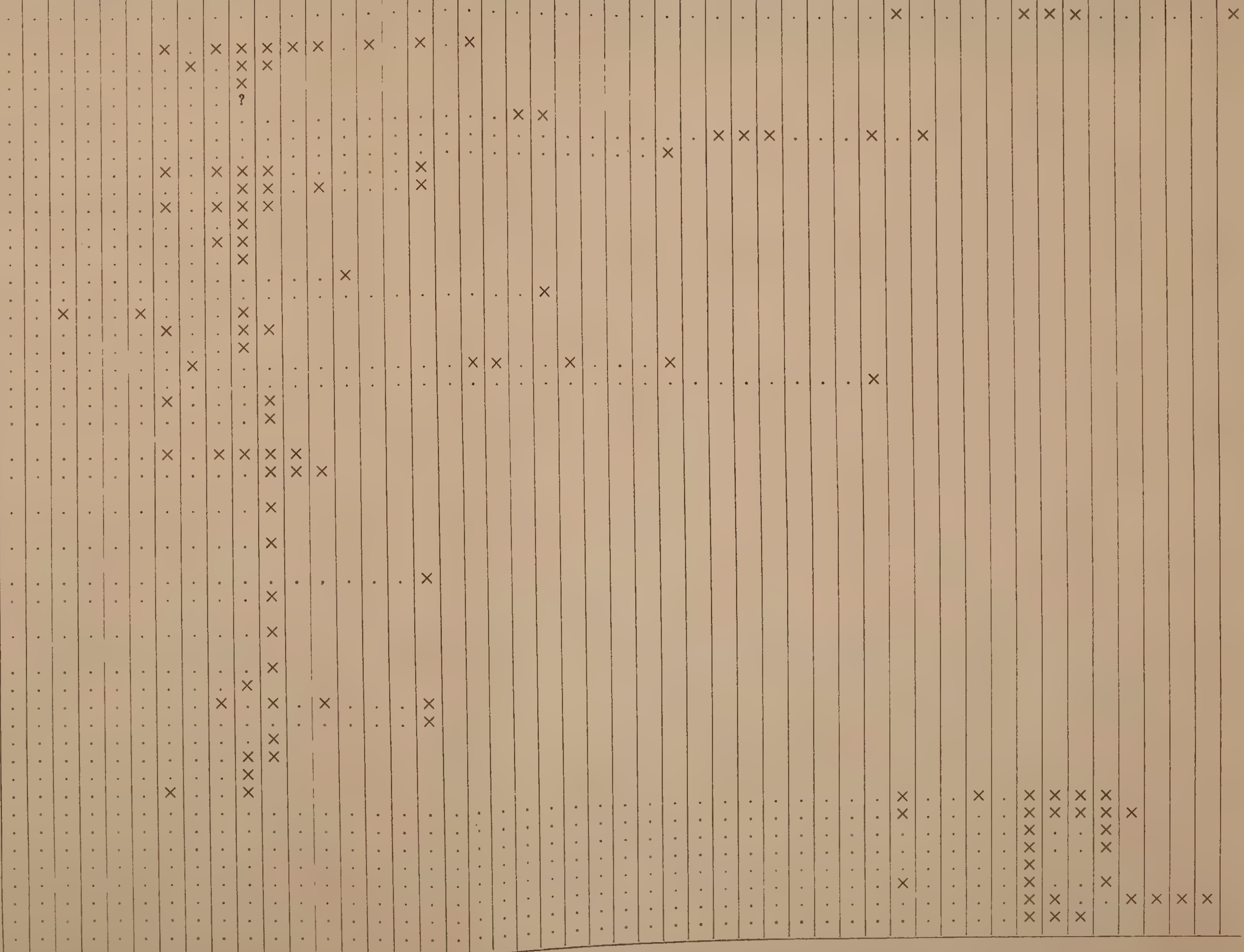





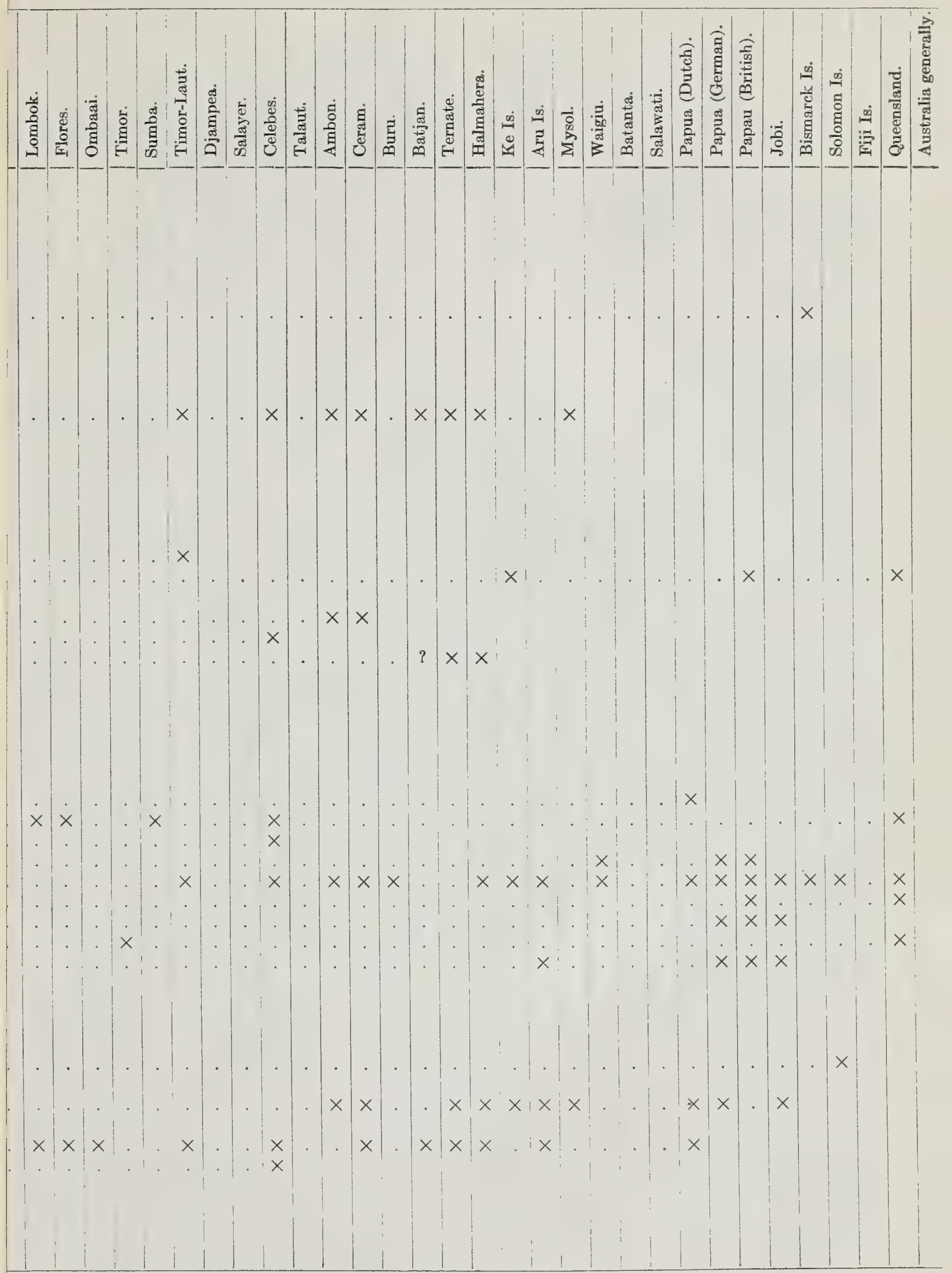


1 
SAtrria.

苟

Gonyocephalus grandis (Cantor) Gonyocephalus beyschlagi Boettger Gonyocephalus herveyi Boulenger

\section{Acenthosaura armata Gray}

Diptychodera lobata Boettger

Japalura nigrilabris (Peters) Japalura ornata van Lidth

\section{Calotes cristatellus (Kuhl)}

Calotes jubatus (Dum. \& Bibr.)

Calot tympanistriga (Gray)

Dendragama boulengeri Doria Dendragama fruhstorferii Boettger

Physignathus maculilabris Boulenger Physignathus temporalis (Günther)

Hydrosaurus amboinensis (Schloss.) Hydrosaurus microlophus (Bleeker)

Hydrosaurus weberi Barbour

Lanthonotus borneensis Steindachner

Varanus dumerilii (Schlegel)

Varanus rudicollis (Gray)

Varanus heterolepis Boulenger

Varanus salvadorii (Ptrs. \& Doria)

Varanus salvator (Laurenti)

Varanus togianus (Peters)

Varanus kalabeck (Lesson)

Varanus indicus (Daudin)

Varanus gouldii (Gray)

Varanus prasinus (Schlegel)

Varanus kordensis Meyer

Varanue nebulosus (Gray)

Takydromus sexlineatus Daudin

Corucia zebrata Gray

Tiliqqua gigas (Schneider)

Mabuya multifasciata (Kuhl)

Mabuya nudis Boutenger

Mabuya rudis Boulenger

Mabuya rugifera Stolicz

Mabuya lewisi Bartlett

Mabuya rubricollis Bartiett

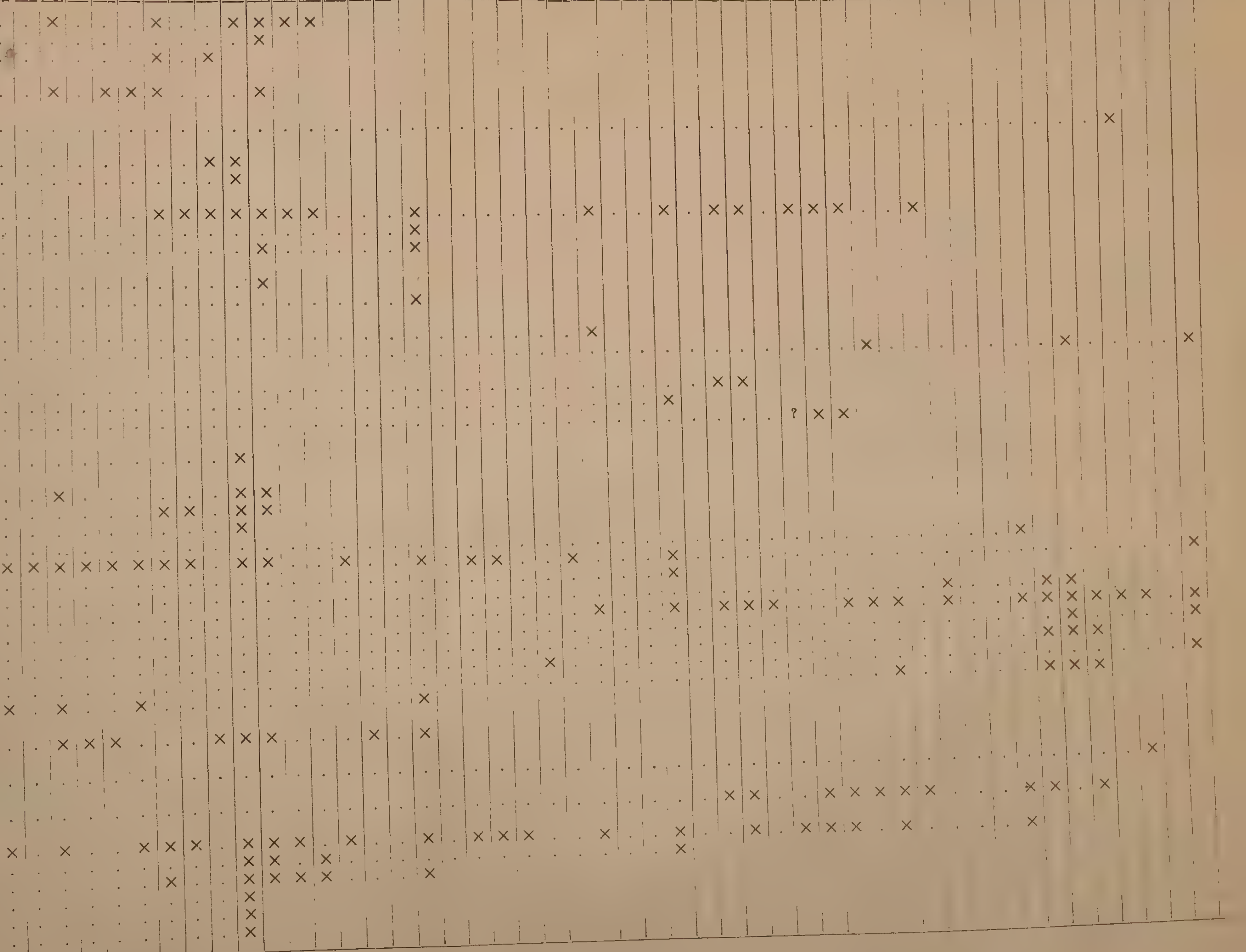





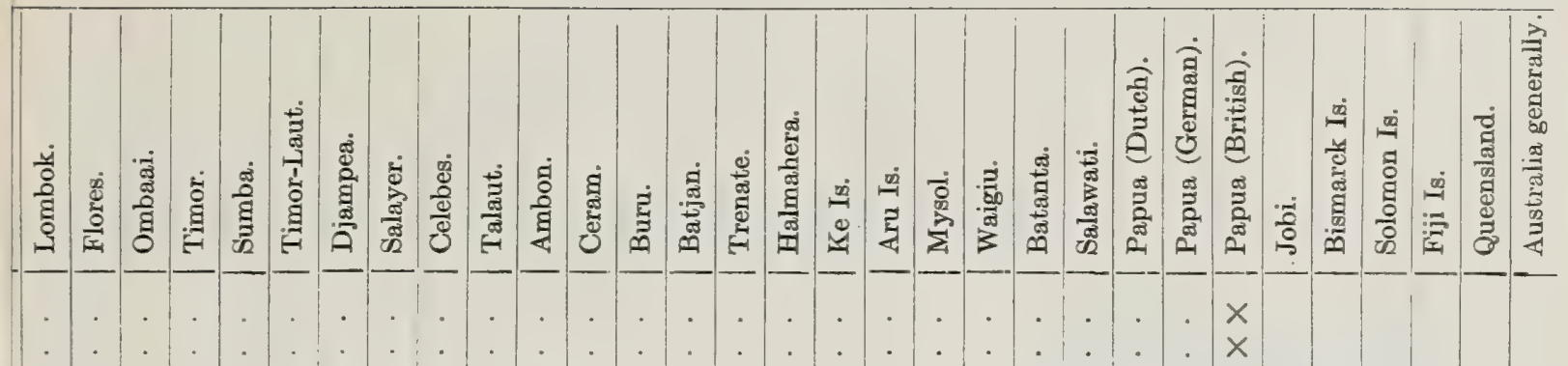
. . . . . . . . $x$

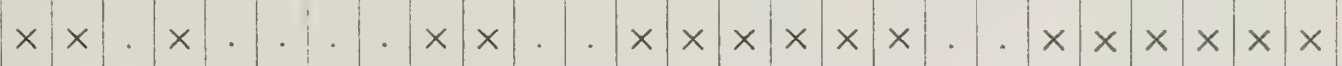

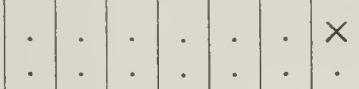
. . . . . . . . . . . . . . $\times$ $x$ $\cdot \cdot \cdot \cdot \cdot \cdot \cdot \cdot \cdot \cdot \cdot \cdot \cdot \cdot \cdot \cdot \cdot \cdot \cdot \cdot \cdot \cdot \cdot \cdot \cdot \cdot \cdot \cdot \cdot \cdot$

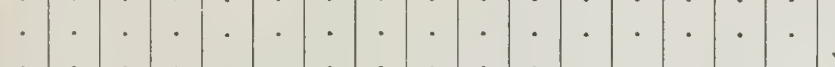

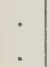

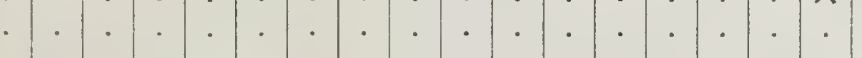

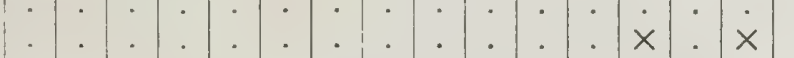

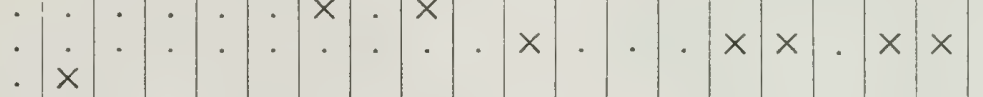

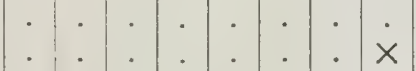

$\therefore x$ . . . . . . . . . $x$

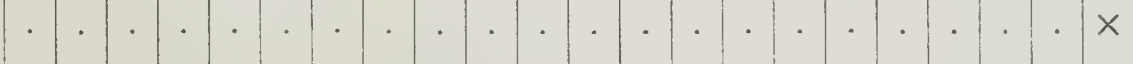

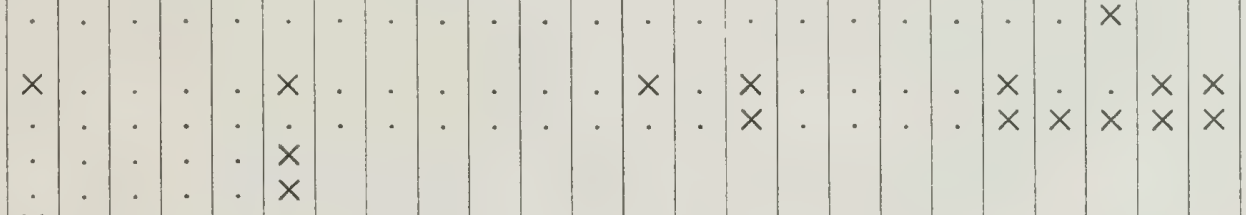

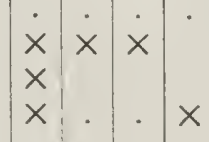

$$
\begin{aligned}
& \text { - } x \\
& x \cdot x \cdot x \cdot x \cdot x \times x \cdot x \times x \times x \times \cdot \times x \times x \times x \times x \times x \\
& \dot{x}|\dot{x}| \dot{x}
\end{aligned}
$$



SAURIA

\section{Otosaurus granulatus (Boulenger)}

Otosaurus annectans (Boulenger)

Dasia smaragdinum (Lesson)

Dasia olivaceum Gray

Dasia villatum (Edeling)

Dasia acutirostrum (Oudemans)

Dasia dahlii (Werner)

Dasia nieuwenhuisui (van Lidth de Jende)

\section{Dasia aignanum (Boulenger)}

Sphenomorphus kuhnei (Roux)

Sphenomorphus dorsalis (Boulenger)

Sphenomorphus minutus (Meyer)

s. \& Doria

s (Ptrs. \& Doria)

Sphen

Sphenomorat

Sphenomer

Sphenomorphe

Sphenomorphus nigrilabris (Gunth

Sphenomorphus simus (Sauvage)

Sphenomorphus buttikoferi (van Lidth)

Sphenomorphus brevipes (Boettger)

Sphenomorphus everetti (Boulenger)

Sphenomorphus louisiadensis (Boulenger)

Sphenomorphus malayanus (Doria)

Sphenomorphus milnensis (Boulenger)

Sphenomorphus modigliani (Boulenger)

Sphenomorphus nigrolineatus (Boulenger)

Sphenomorphus shelfordi (Boulenger)

Sphenomorphus variegatus (Peters)

Sphenomorphus jobiensis (Meyer)

Sphenomorphus saracinorum (Boulenger)

Sphenomorphus tropidonotus (Bouleng

Sphenomorphus florensis (M. Weber)

Sphenomorphus striolatus (M. Weber)

Sphenomorphus emigta (

Sphomp

Spheno

(Dum. \& Bibr.)

Sphenomorphus solomonis (Boulenger)

Sphenter

Sphenomorphus grugnus (Roux)

Emoia cyanurum (Lesson)

Emoia mivarti (Boulenger)

Emoia cyanogaster (Lesson)

Emoia вorex (Boettger) ${ }^{1}$

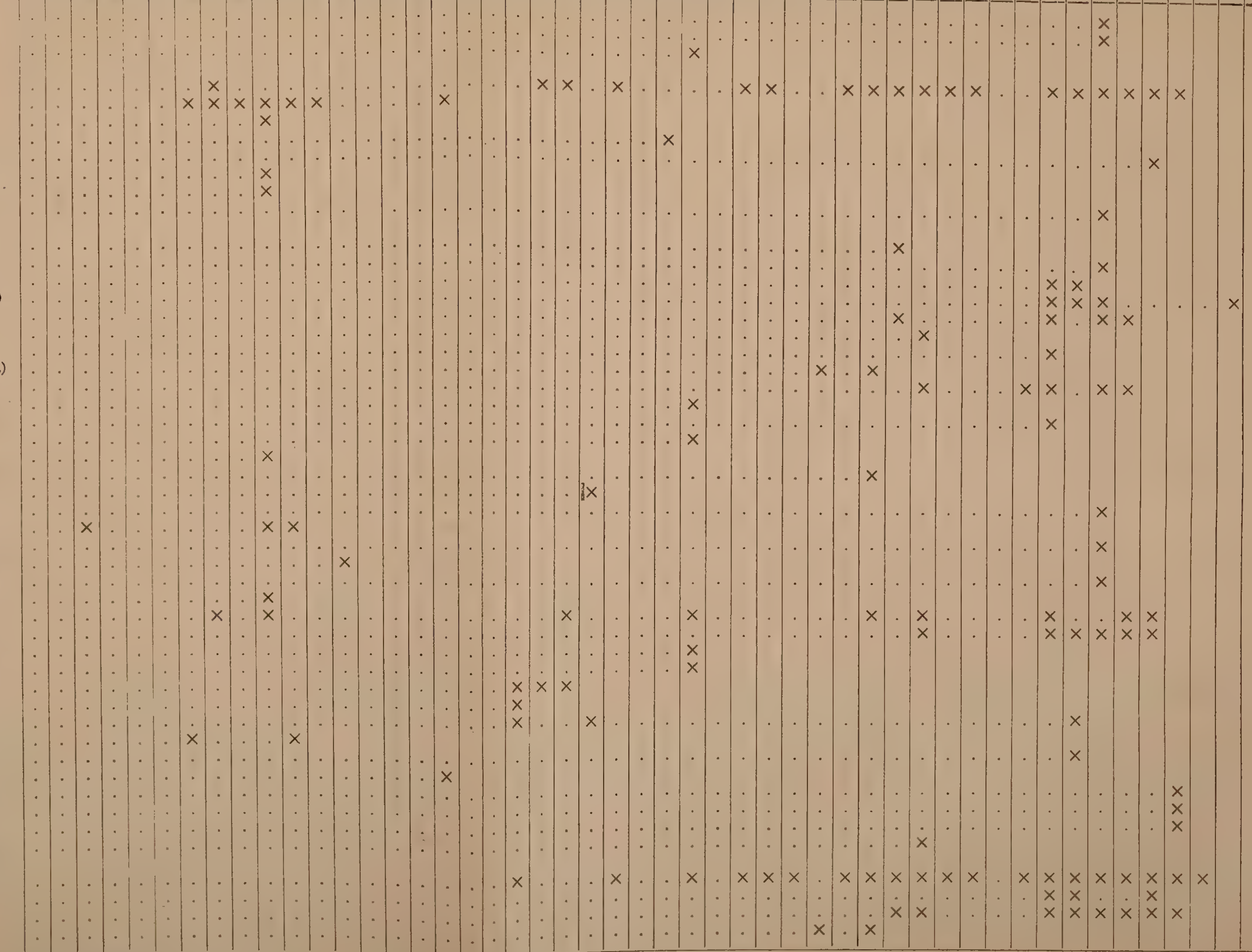

'Obi Island. 



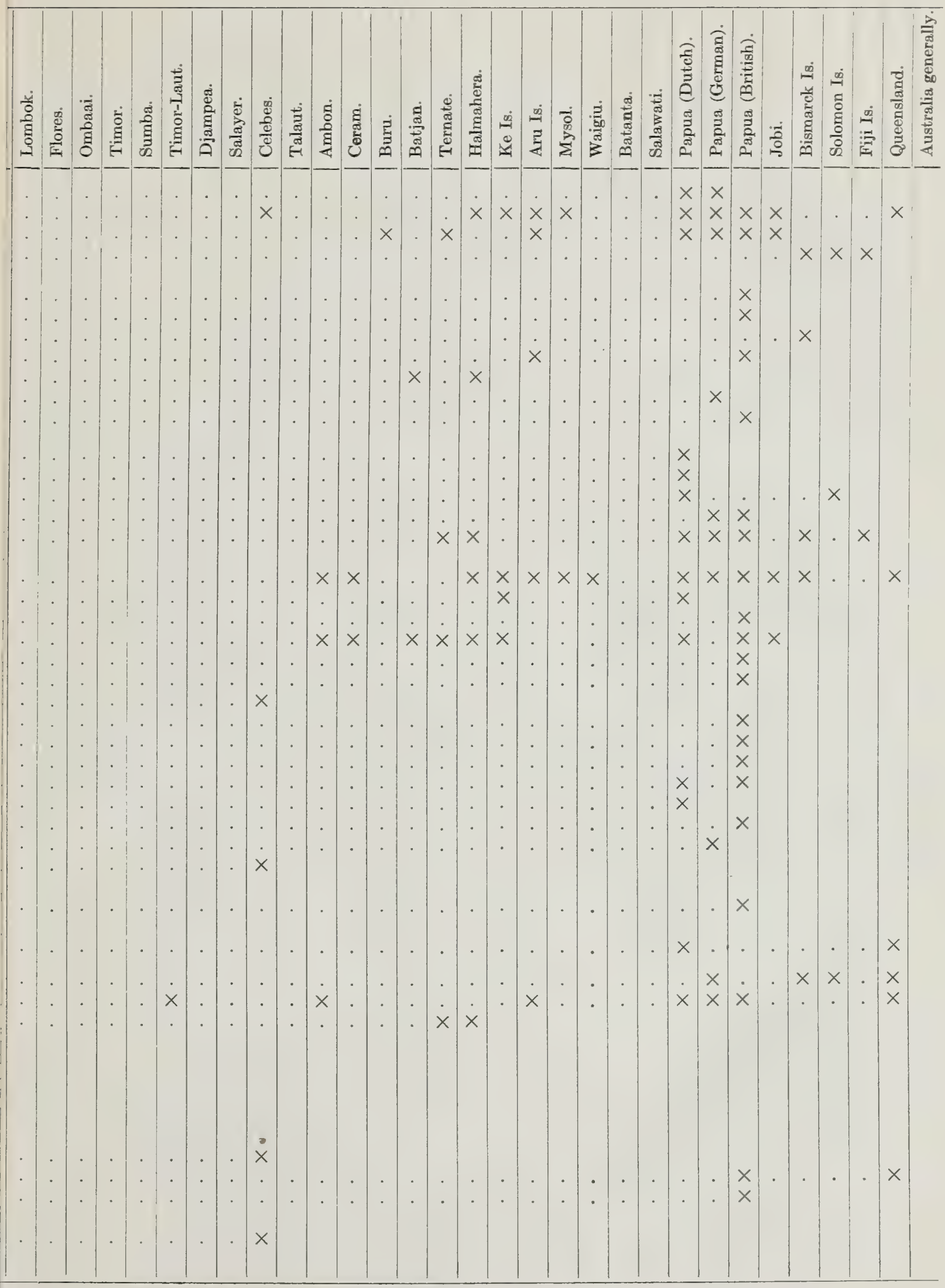


SAURIA

Emoia callistictum (Ptrs. \& Doria) Emoia a trocostatum (Les Emoia baudinii (Dum. \& Bibr.) Emoia nigrum (Hombr. \& Jacq.) Emoia parietale (Peters) Emoia palidiceps De Vi Ernoia cuneiceps De Vis Emoia impar (Werner)

Emoia iridescens (Boulenger) Emoia kukenthali (Boettger) Emoia mehelyi Werner Emoia tetrataenia (Boulenger)

Leiolepisma pullum Barbour Leiolepisma semperi (Peters) Leiolepisma anolis (Boulenge Leiolepisma virens (Peters) Leiolepisma noctua (Lesson)

Leiolepisma nitens (Peters) Leiolepisma fuscura (Dum. \& Bibr.) Leiolepisma beccarii (Ptrs. \& Doria) Leiolepisma bicarinatum (Macleay) Leiolepisma novae-guineae (Meyer) ${ }^{1}$ Leiolepisma atrogulare (Douglas Ogilby) Leiolepisma curtum (Boulenger) Leiolepisma inconspicuum (F. Müller) Leiolepisma longiceps (Boulenger) Leiolepisma miotis (Boulenger) Leiolepisma nigrigulare (Boulenger) Leiolepisma pulcrum (Boulenger) Leiolepisma stanonleyanum (Boulenger Leiolepisma subnitens (Boettger) Leiolepisma textum ( $F$. Muller) Leiolepisma vittigerum (Boulenger) Leiolepisma elegans (Boulenger) Lellopisma miangense Werner Riopa albofasciolatum (Günther) Riopa rufescens (Shaw) Riopa mentovarium (Boettger). Riopa bowringii (Günther) Riopa schneideri (Werner) Riopa whiteheadi (Mocquard) Riopa bampfyeldei (Bartlett) Riopa opisthorhodum Werner Homolepida temminckii (Dum. \& Bibr.) Homolepida crassicaudam (A. Dum.) Homolepida forbesii (Boulenger) Homolepida hallieri van Lidth Homolepida parvum (Boulenger) Homolepida alfredi (Boulenger)

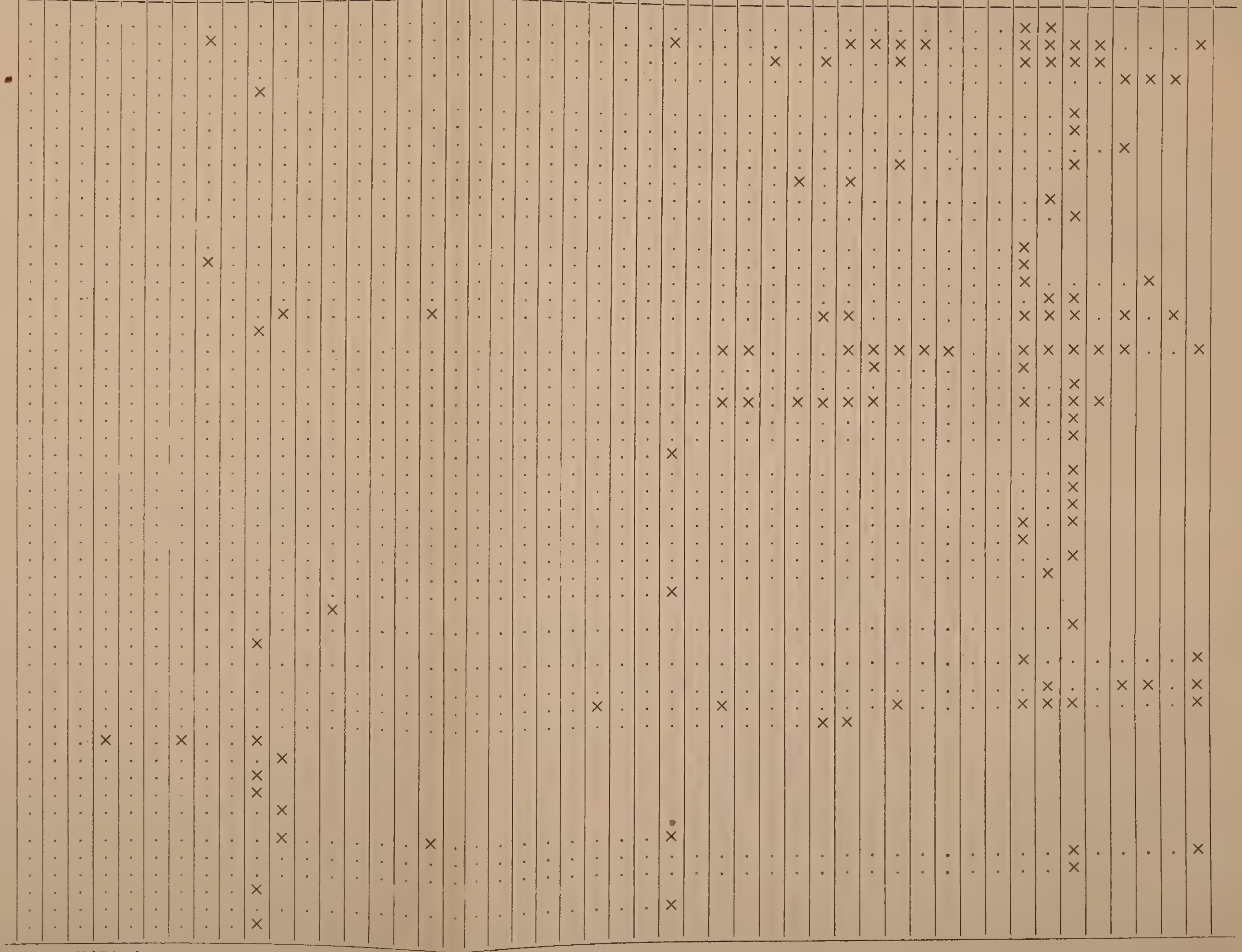

${ }^{2}$ Obi Island. 



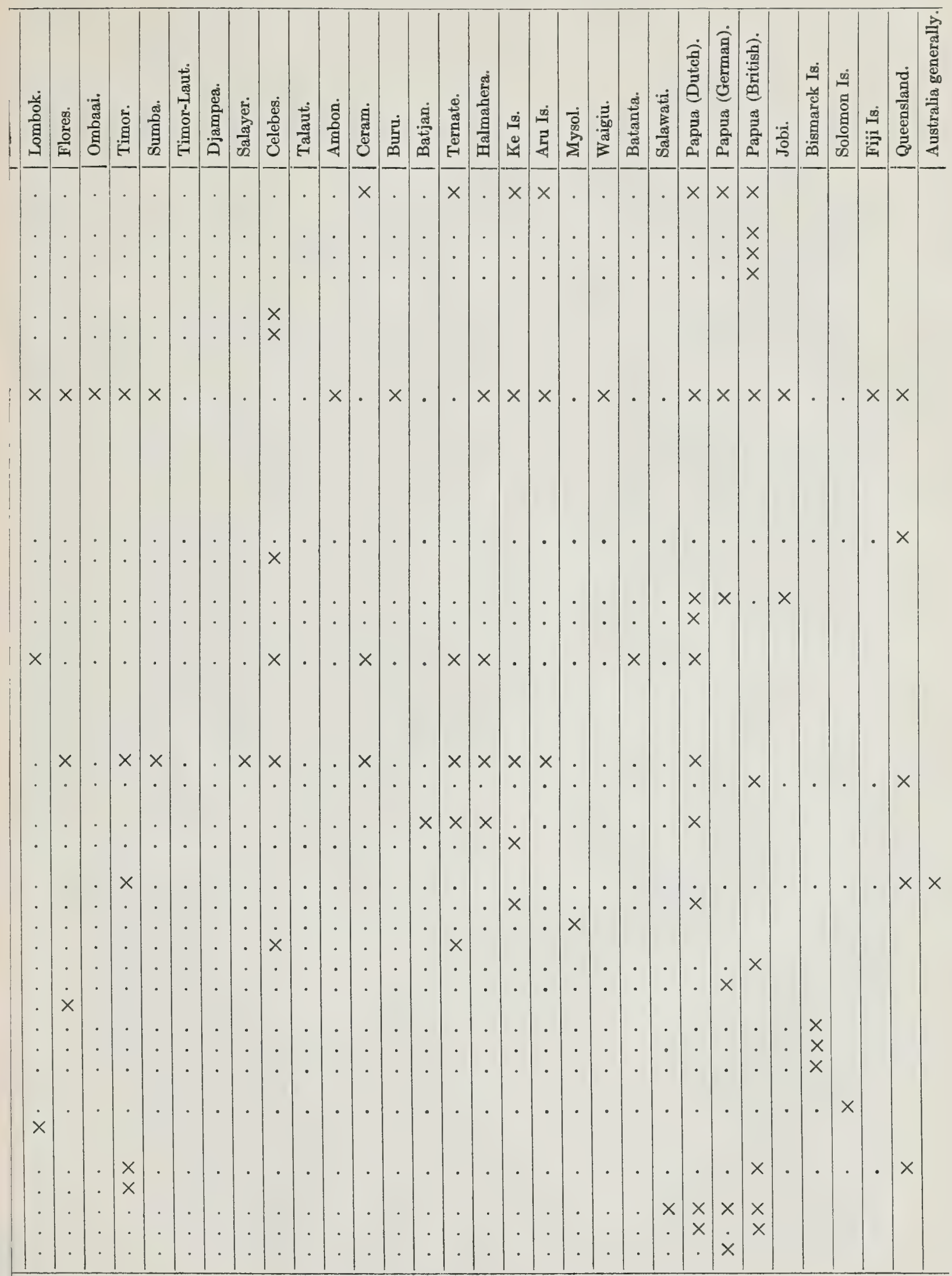


1 
Lygosoma muelleri (Schlegel)

Lygosoma chalcides (Linné)

Lygosoma pratti (Boulenger)

Lygosoma sumatrense (Günther)

Lygosoma loriae Boulenger

Siaphos infralineolatum (Günther) Siaphos quadrivittatum (Peter Siaphos relictum (Vinciguerra)

Cryptoblepharus boutonii (Desjardin)

Tropidophorus beccarii (Peters)

Tropidophorus brookii (Gray)

Tropidophorus iniquus van Lidth

Tropidophorus micropus van Lidth

Tropidophorus mocquardii Boulenger

Tropidophorus queenslandiae DeV

Tropidophorus grayi Günther

Tribolonotus novae-guineae (Schlegel) Tribolonotus gracilis de Rooy

Dibamus novae-guineae Dum. \& Bibr.

SERPENTES.

Typhlops lineatus Schlegel

Typhlops braminus (Daudin)

Typhlops leucoproctus Boulenge

Typhlops muelleri Schlegel

Typhlops flaviventer Pe

Typhlops kraalii Doria

Typhlops bisubocularis Boettger

Typhlops polygrammicus Schleg

Typhlops multilineatus Sch)

Typhlops olivaceus (Gray)

Typhlops ater Schlegel

Typhlops inornatus Bouleage

- Typhlops erycinus Werne

- Typhlops floris Boulenger

- Typhlops depressus Peters

- Typhlops philococos Werner

- Typhlops subocula

- Typhlops lorenzi Werner

Typhlops aluensis Boul

Typhlops elberti Roux

Liasis fuscus Peters

Ligin mibr.

Lisis albertiai Ptra \& Doria

Liasis popuanus Ptrs. \& Doria

Liasis papuanus

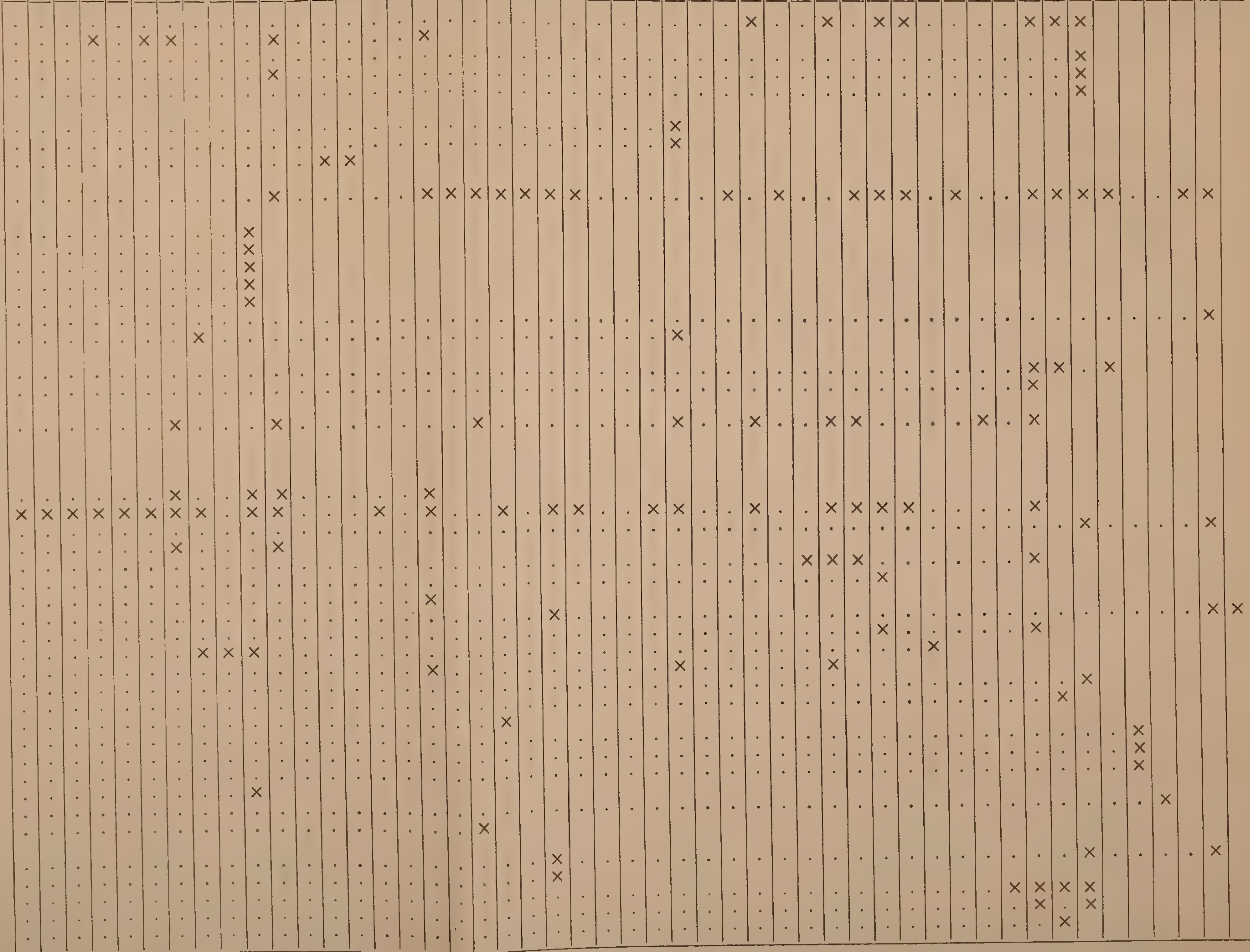





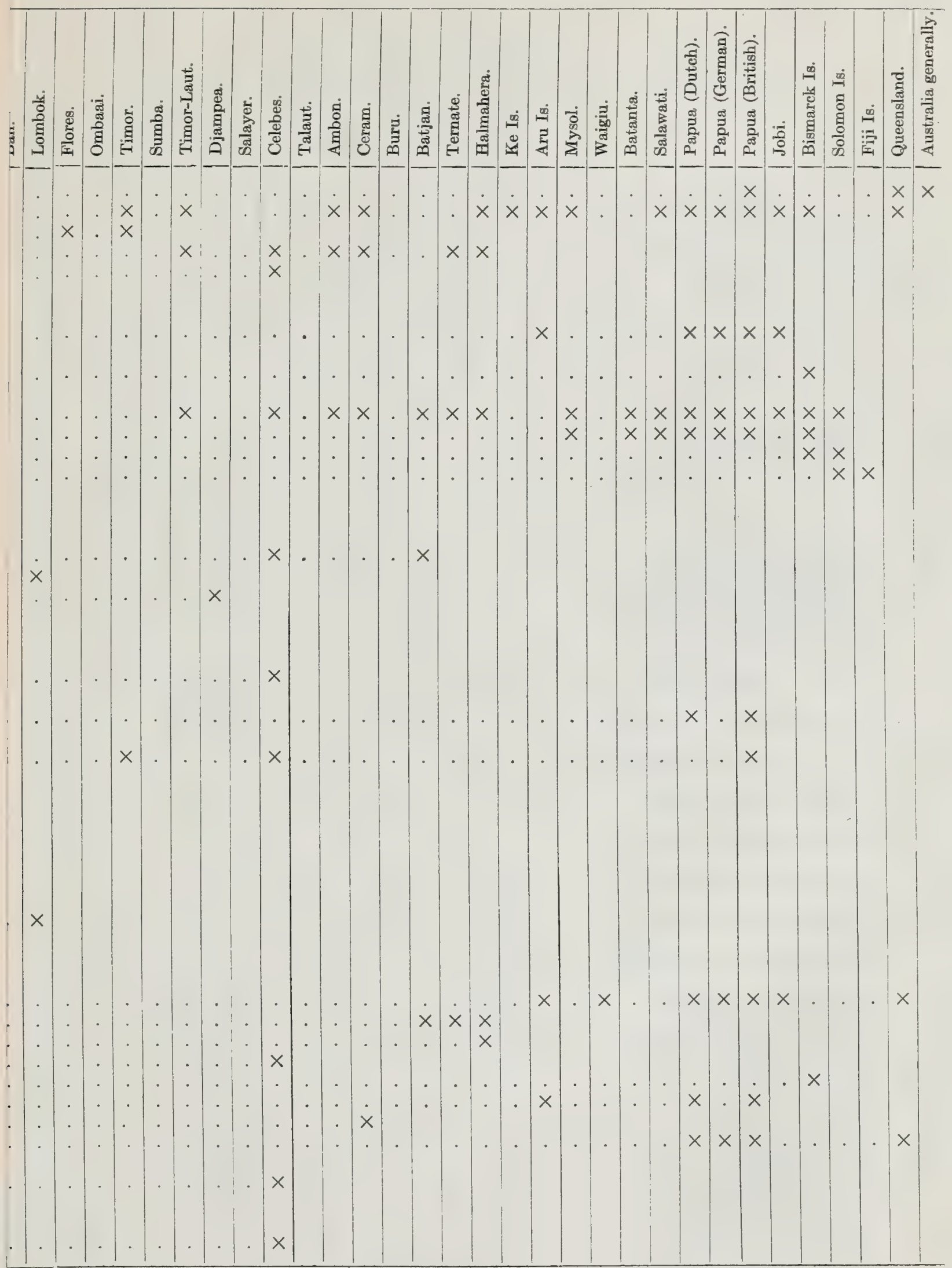


Python spilotes (Lacep.)

Python amethystinus (Schneider)
Python timorensis (Peters)

Python reticulatus (Schneider)

Python bivittatus Schlegel

Python curtus Schlegel

Chondropython viridis (Schlegel)

Nardoa boa (Schlegel)

Enygrus carinatus (Schneider)

Enygrus asper (Günther)

Enygrus australis Montrouzier
Enygrus bibronii Hombr. \& Jacq.

Anomalochilus weberi van Lidth

Cylindrophis rufus (Laurenti) Cylindrophis opisthorhodus Boulenge Cylindrophis isolepis Boulenger Cylindrophis lineatus Blanford Cylindrophis boulengeri Roux ${ }^{1}$

Xenopeltis unicolor Reinwardt

Acrochordus javanicus Hornstedt

Chersydrus granulatus (Schneider)

Xenodermus javanicus Reinh.

Stoliczkaia borneensis Boulenger

Anoplohydrus aemulans Werne

Sibynophis geminatus (Boie)

Xenochrophis viperinus Schenkel

Natrix picturata (Schlegel)

Natrix truncata (Peters)

Natrix punctiventria (Boettger)

Natrix celebica (Ptrs. \& Doria)

Natrix dahli Werne:

Natrix doriae Boulenge

Natrix elongata (Jan)

Natrix elongata (Jan)

Natrix conspicillata (Günther)

Natrix trianguligera (Boie)

Natrix petersii (Boulenger)

Natrix piscator (Schneider)

Natrix vittata (Linné)

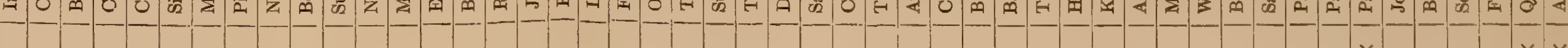

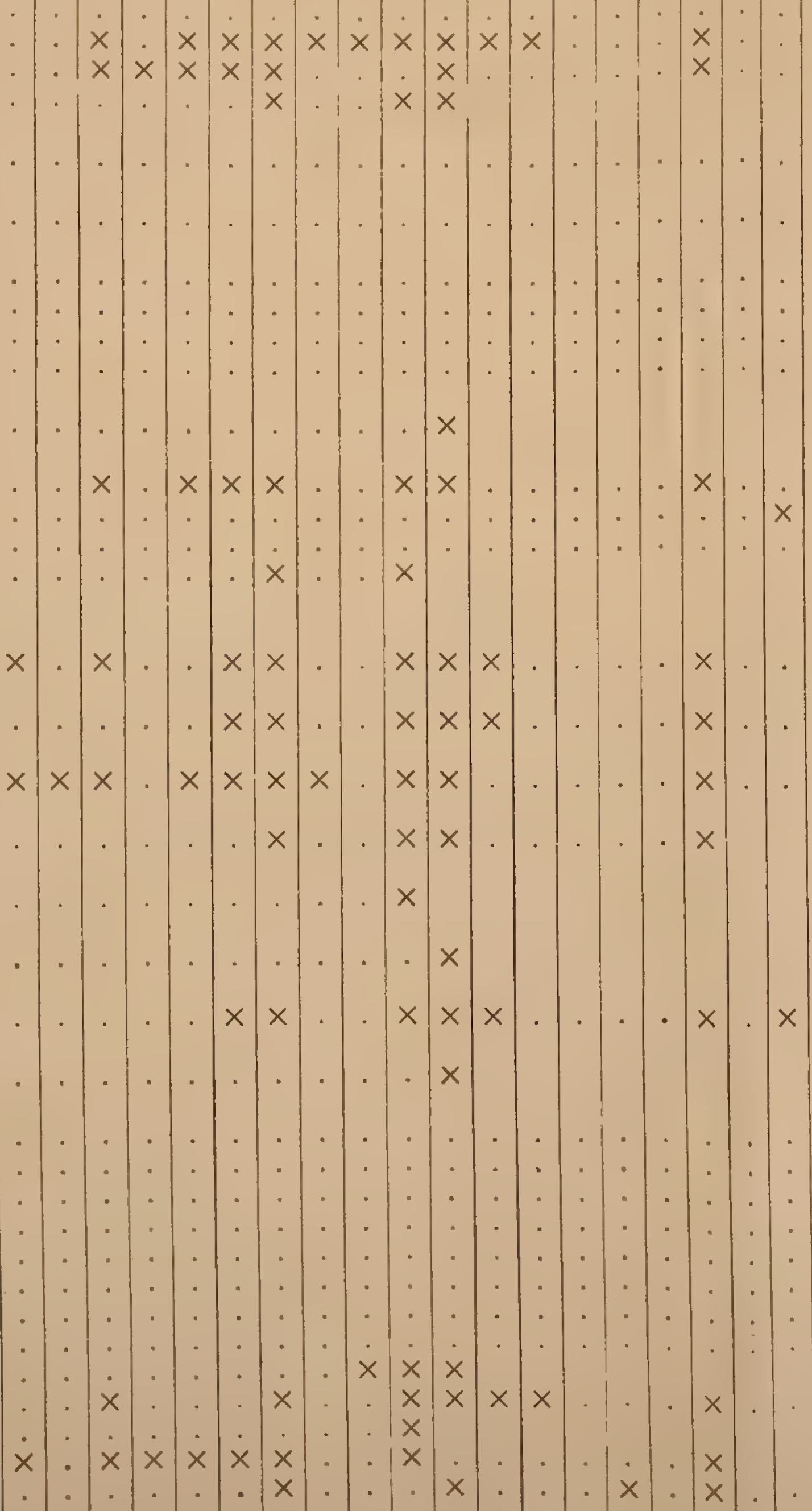

'Wetter Island. 



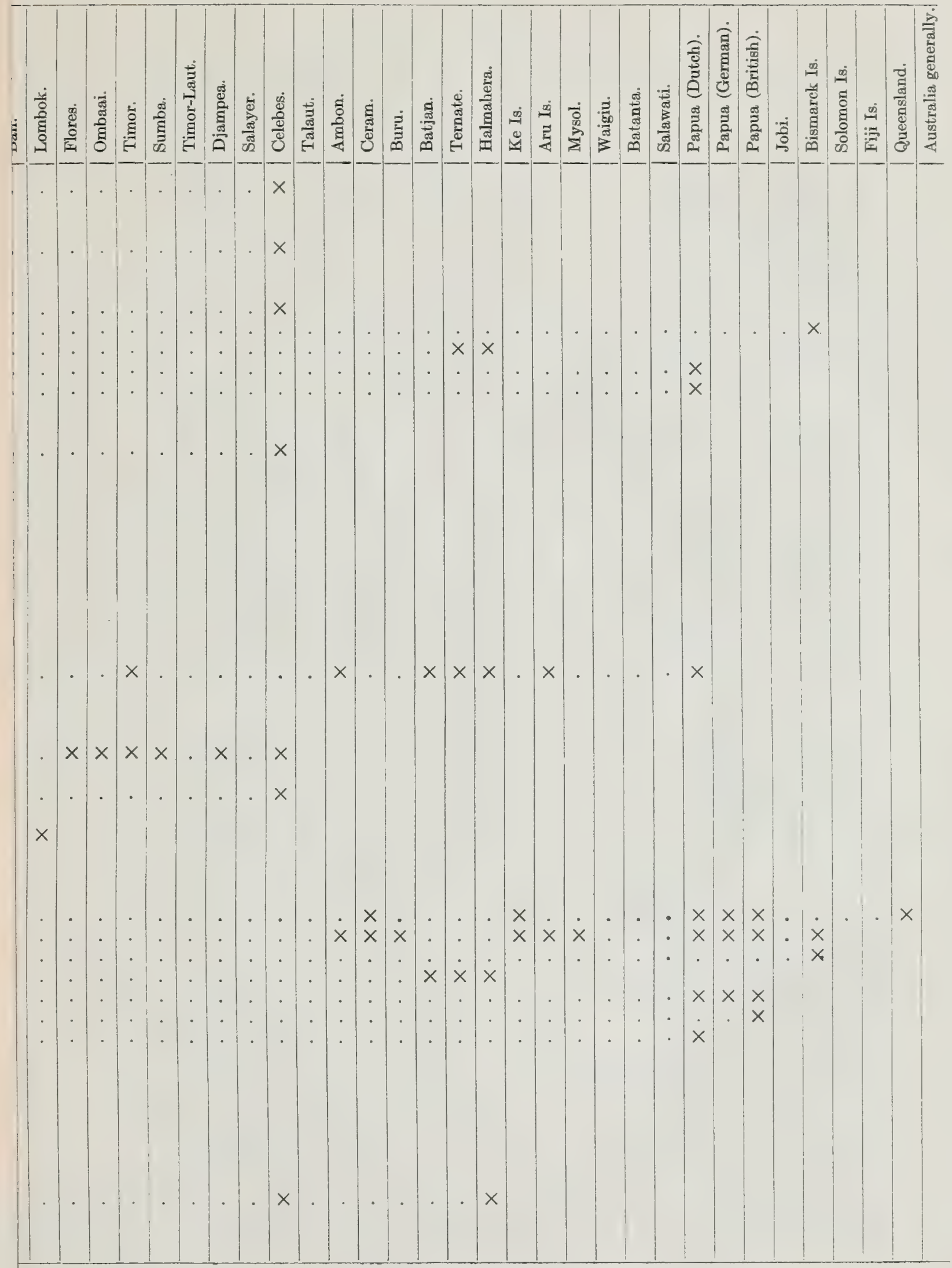


Natrix subminiata (Schlegel)

Natrix chrysarga (Schlegel)

Natrix maculata (Edeling)

atrix changes (Gunther)

Natrix faravif

atrix farrion (Boulenger)

(Boulenger)

Natrix halmaherica (Boettger)

Natrix montana (van. Lidth de Jeude)

Natrix novae guineae (van. Lidth de Jeude)

Macropisthodon flaviceps (Dum. \& Bibr.) Macropisthodon rhodomelas (Boie)

Pseudoxenodon intermedius Lönnberg Pseudoxenodon inornatus (Boie)

Hydrablabes periops (Günther) Hydrablabes praefrontalis (Macquard)

Opisthotropis rugosa (van Lidth de Jeude) Opisthotropis typica (Mocquard)

\section{Brachyorrhus albus (Linné)}

\section{Elapoides fuscus Boie}

Lycodon aulicus (Linné) Lycodon effrenis Cantor

Lycodon stormi Boettger

Lycodon albofuscus (Duis

Lepturophis borneensis Boulenger

Stegonotus cuculatus (Dum. \& Bibr.)

Stegonotus modestus (Schlegel)

egonotus heterurus Boulenger

tegonotus batjanensis (Günther)

tegonotus guentheri Boulenger

Ster

Dryocalamus subanulatus (Dum. \& Bibr.)

Dryocalamus tristrigatus (Günther)

Zaocys carinatus (Günther)

Zrocys fuscus (Günther)

Ptyas dipsas (Schlegel)

Ptyas korros (Schlegel)

Ptyas mucosus (Linné)

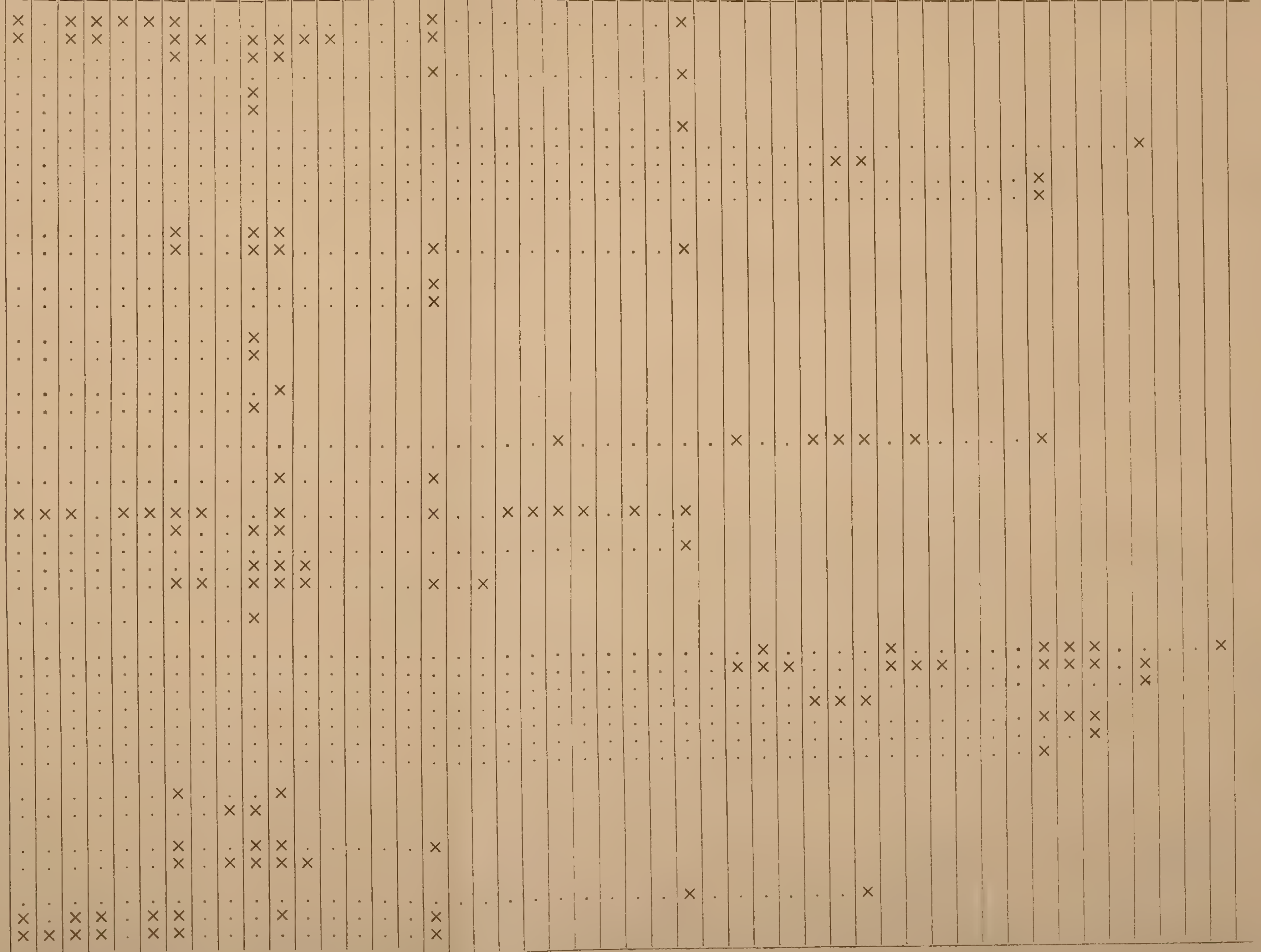





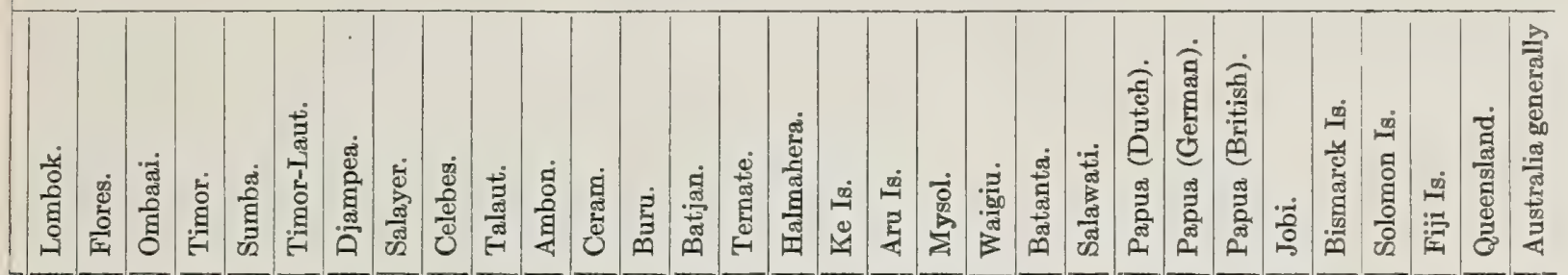

$$
\begin{aligned}
& \cdot \cdot \cdot \dot{x} \cdot \cdot \cdot \cdot \cdot \cdot \times
\end{aligned}
$$

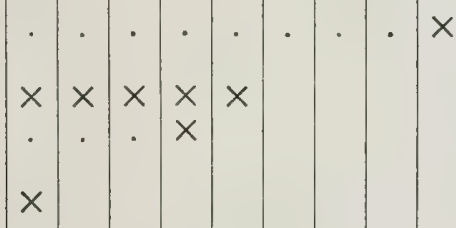

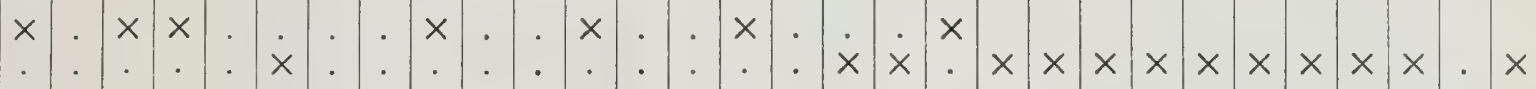

$$
\begin{aligned}
& \text {.. . . . . . . . . . . . . . . } \times \text {. . . . } \times \times \times \times \times \times
\end{aligned}
$$

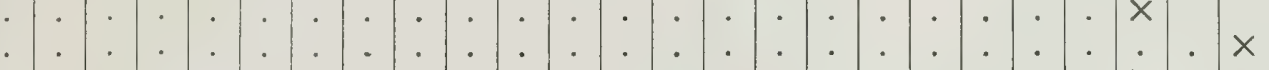

$$
\begin{aligned}
& \cdot \cdot \cdot \cdot \cdot \cdot \cdot \cdot \cdot \cdot \cdot \cdot \cdot \cdot \cdot \cdot \cdot \cdot \cdot \cdot \cdot \cdot \cdot \cdot \cdot \cdot \cdot \cdot \cdot \cdot \frac{x}{x}
\end{aligned}
$$

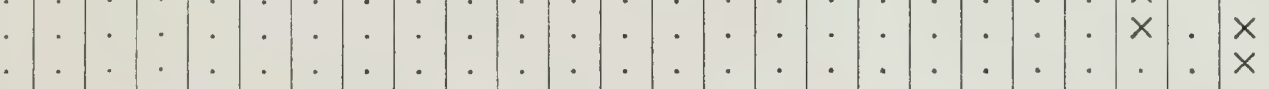

$$
\begin{aligned}
& \text {. . . } x \\
& \times \\
& x \times x
\end{aligned}
$$

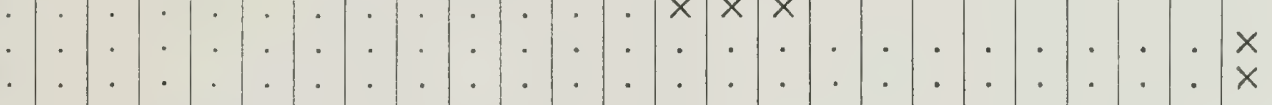


Xenelaphis hexagonotus (Cantor) Xenelaphis ellipsifer Boulenger

Elaphe porphyracea (Cantor) Elaphe taeniura (Cope)

Elaphe janseni (Bleeker)

Elaphe melanura (Schlegel) fecorolimain Elaphe radiata (Schlegel) Elaphe erythrura (Dum. \& Bibr.) Elaphe enganensis (Vinciguerra) Elaphe subradiata (Schlegel) Elaphe timoriensis (B. Ferreira)

Gonyosoma oxycephala (Boie)

Gonyophis margaritatus (Peters)

Dendrophis pictus (Gmelin) Dendrophis calligester Gïnther

Dendrophis formosus Boie

Dendrophis lineolatus Hombr. \& Jacq

Dendrophis gestrostictus Boulenger

Dendrophis meeki Boulenger

Dendrophis nouhuysii van Lidth de Jeude

Dendrophis lorentrii van Lidth de Jeude

Dendrophis elerane Dougses Ogiby

De

Dendrelaphis inornatus Boulenger

Dendrelaphis candolineatus (Gray)

Dendrelaphis terrificus (Peters)

Dento

Dentrophi papues

Dendrelaphis schlenckeii Douglas Ogilby

Holarchus purpurascens (Schlegel)

Holarchus octolineatus (Schneider)

Holarchus forbesii (Boulenger)

Holarchus signatus (Günther)

Holarchus annulifer (Boulenger)

Holarchus subcarinatus (Günther)

Oligodon bitorquatus Boie

Oligodon trilineatus (Dum. \& Bibr.)

Oligodon everetti Boulenger

Oligodon propinquus Ja

Oligodon vertebralis (Günther)

Olgodon waandersii (Bleeker)

Oligodon taeniurus F. Müller

Oligodon pulcherrimus Werne

Liopeltis tricolor (Schlegel)

Liopeltis longicaudus (Peters)

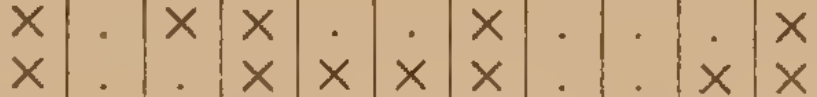

$\dot{x} \dot{x} \dot{x} \dot{x} \cdot \dot{x} \dot{x}$

$\dot{x}: \begin{array}{llll}x & x & x & x \\ x & x & x\end{array}$

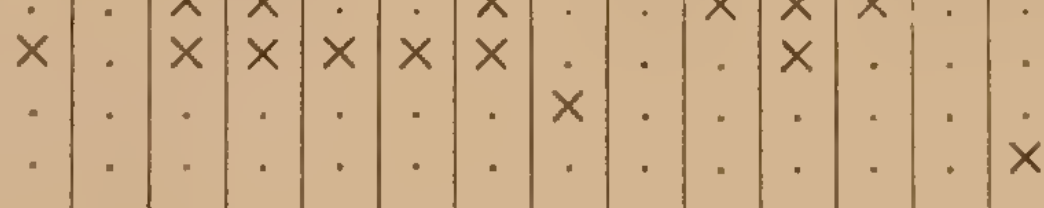

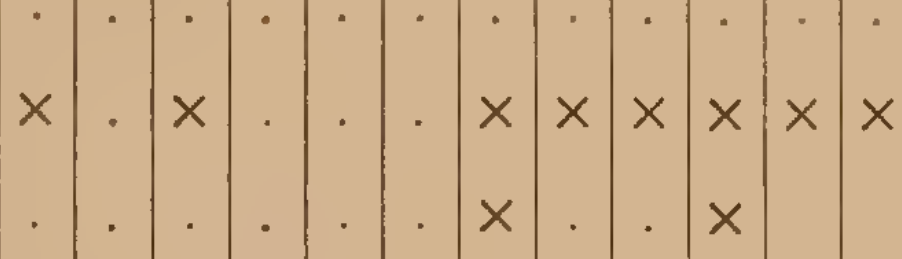

$x \cdot x \cdot x \times x \times x \times x$

$x \dot{x}: \dot{x} \dot{x} \dot{x} \dot{x} \dot{x} \dot{x}$
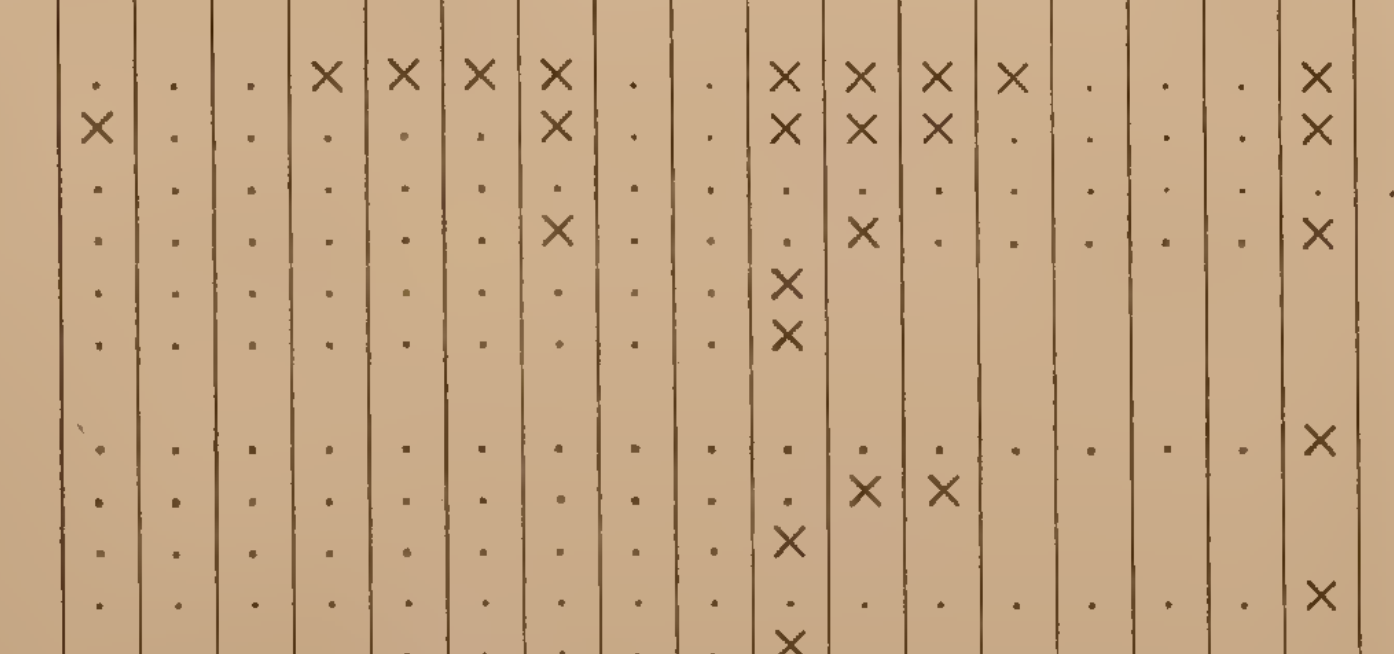



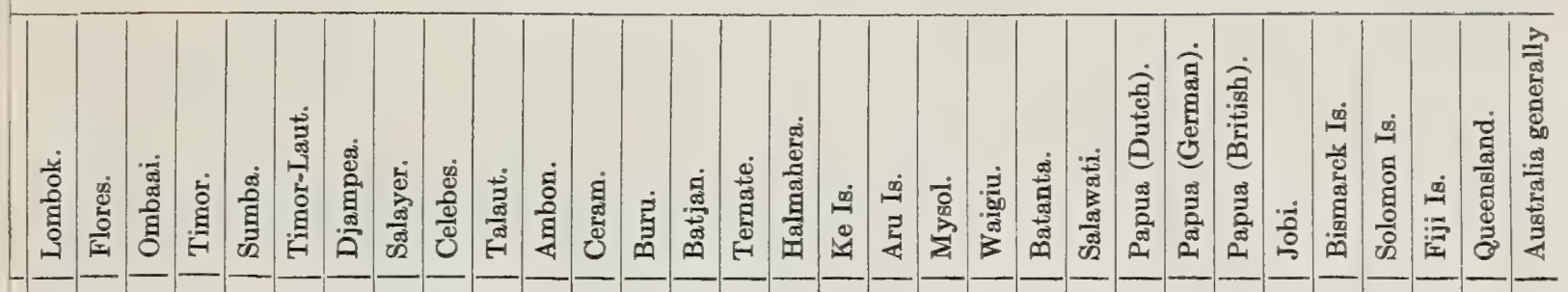

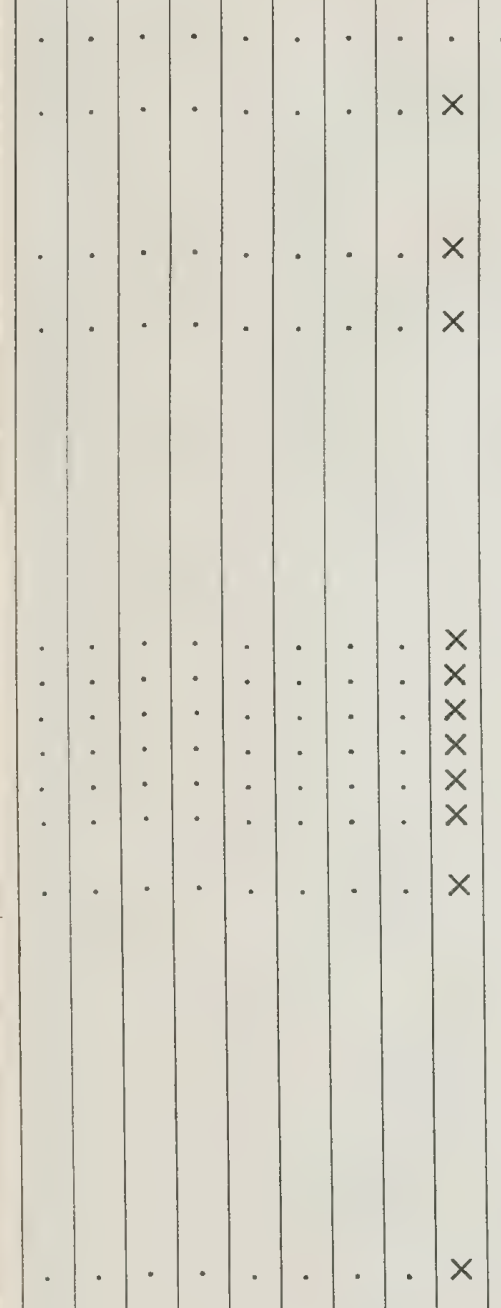


SERPENTES.

Liopeltis libertatis Barbour

Liopeltis baliodinum (Boie)

Oreocalamus hanitschi Boulenger

Idiopholis collaris Mocquard Idiopholis everetti Shelford

Calamorhabdium kukenthali Boettger

Agrophis sarasinorum F. Müller Agrophis saravacensis Shelford Agrophis albonuchalis (Günther)

Rhabdophidium forstenii (Dum. \& Bibr.)

Pseudorhabdium longiceps (Cantor)

Calamaria lumbricoidea Boie

Calamaria vermiformis (Dum. \& Bibr.)

Calamaria stahlknechtii Stolizka

Calamaria baluensis Boulenge

Calamaria grabowakii Fischer

de Jend

Calamaria margaritophora Bleeke

Calamaria acutiostris Boulenger

Calamania nuchalis Boulenger

Calamasia muellen Boulenger

Calamaria cura Boulouger

Calasoria gracilis Bouldnger

Calamain suratrane Edeling

Calamaria virgulata Boie

Calamaria leucogaster Bleeker

Calamaria oceipitalis Jan

Calamaris

Calamaria bicolor Dum. \& Bibr.

Calamaria lateralis Mocquard.

Calamaria laterals Mocqu

Calamaria vebentischii Bleek

Calamaria agamensis Bleeker

Calamaria leucocephala Dum. \& Bibr

Calamaria schlegelii Dum. \& Bibr.

Calamaria linnei Boie

Calamaria borneensis Bleeker

Calamaria benjaminsij Edeling

Calamaria javanica Boulenger

Calamaria pavimentata Dum. \& Bibr.

Calamaria melanota (Jan)

Calamaria lovii Boulenger

Calamaria gracillima Günthe

Calamaria brookii Boulenger

$x$
$x$

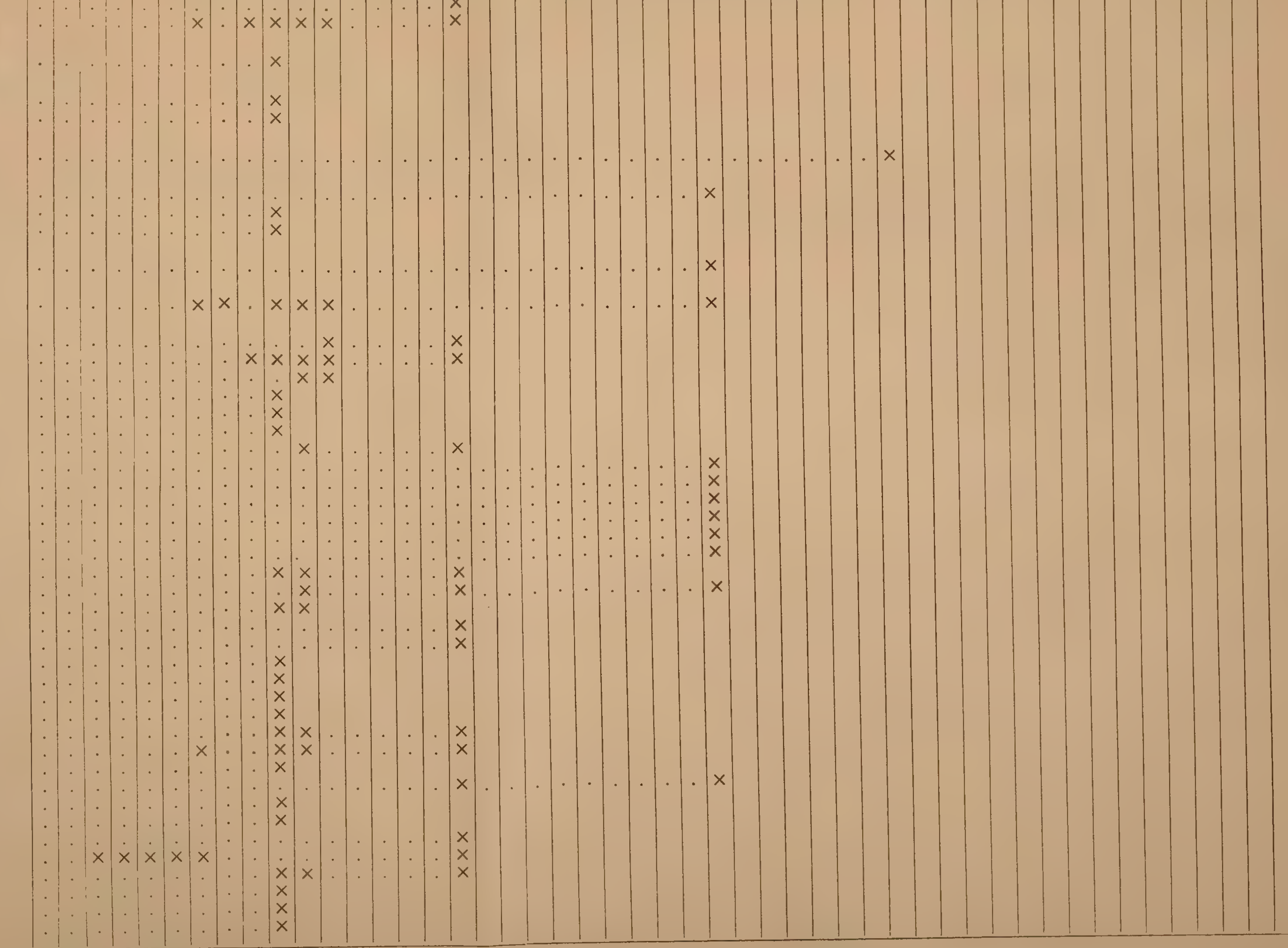





|

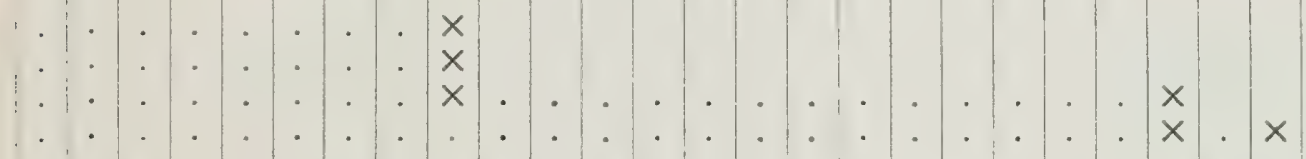

$x \times x \times \cdot x \cdot x \cdot x \cdot x$

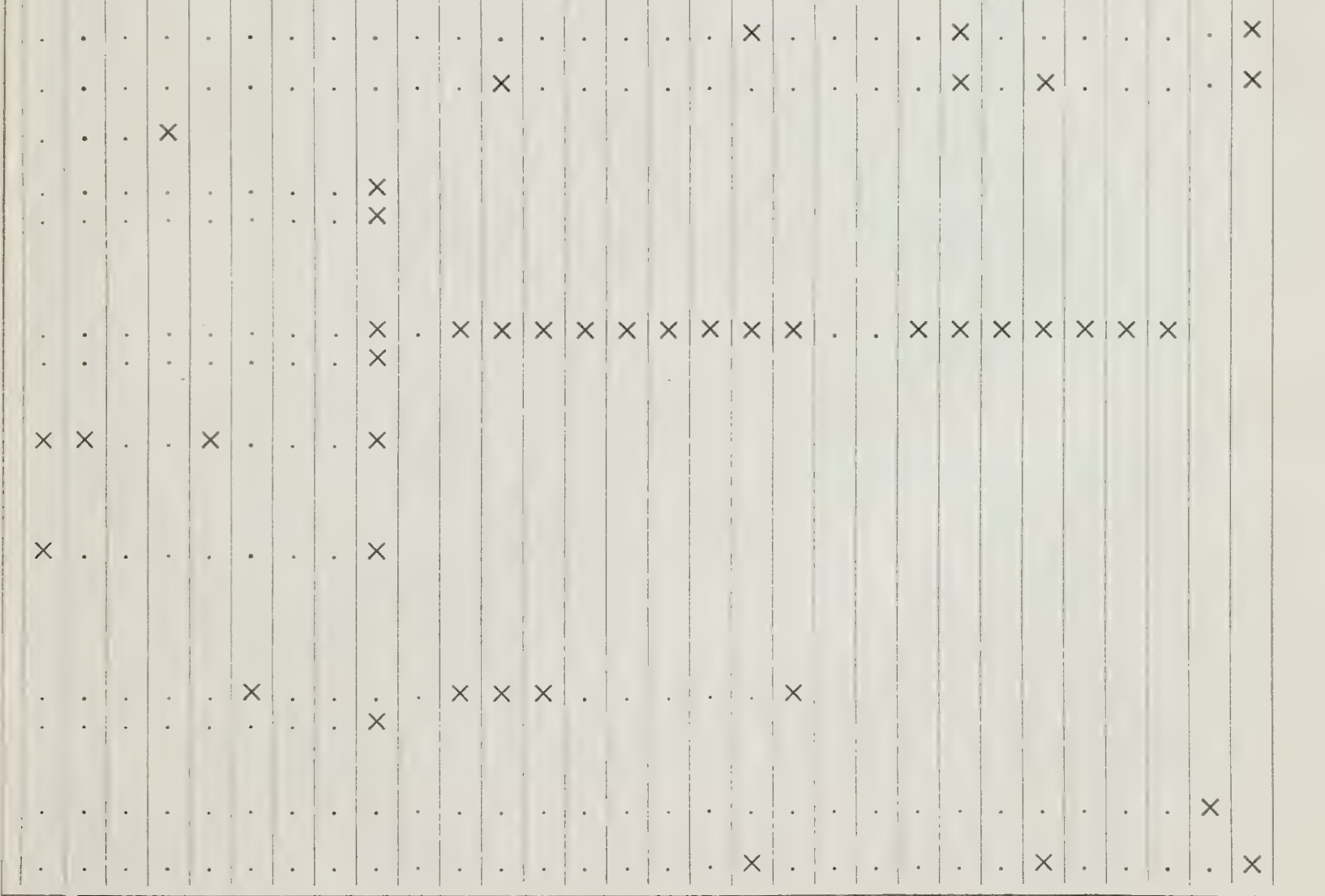


SERPENTES.

Calamaria brachyura Boulenger

Calamaria semiannulata Boettge

Calamaria hosei Günther

Calamaria doderleini Gough

Calamaria mehelyi Schenkel

Calamaria indraginia Schenkel

Calamaria everettii Boulenger

Calamaria ornata Werner

Iguanognathus werneri Boulenger

Enhydris alternans Reuss

Enhydris plumbea (Boie)

Enhydris metaunensis (Boulenger)

Enhydris enhydris (Schneider)

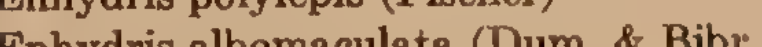

Enyydris punctate (Gray)

Enhydris punctata (Gray)

Homalopsis buccata (Linné)

Hurris rhynchops (Schneider)

Myron richardsonii Gray

Fordonia leucobalea (Schlegel)

Cantoris violacea Girard

Boiga multimaculata (Boie)

Boiga dendrophila (Boie)

Boiga nigriceps (Günther)

Boiga jaspidea (Dum. \&

Boiga drapiezii (Boie)

Boiga, irregularis (Bechstein)

Boiga flavescens (Dum
Boiga cynodon (Boie)

Pagmmodynastes pulverulentus (Boie) Psammodynastes pictus (Günther)

Dryophis xanthozona Boie

Dryophis prasinus Boie

Dryophis fasciolatus (Fischer)

Dryophiops rubescens (Gray)

Chrysopelea shodopleuron Boie

Chrysopelea ornata (Shaw)

Chrysopelea chrysochlora (Sohlegel)

Ogmodon vitianus Peters

Glyphodon tristis Gunther

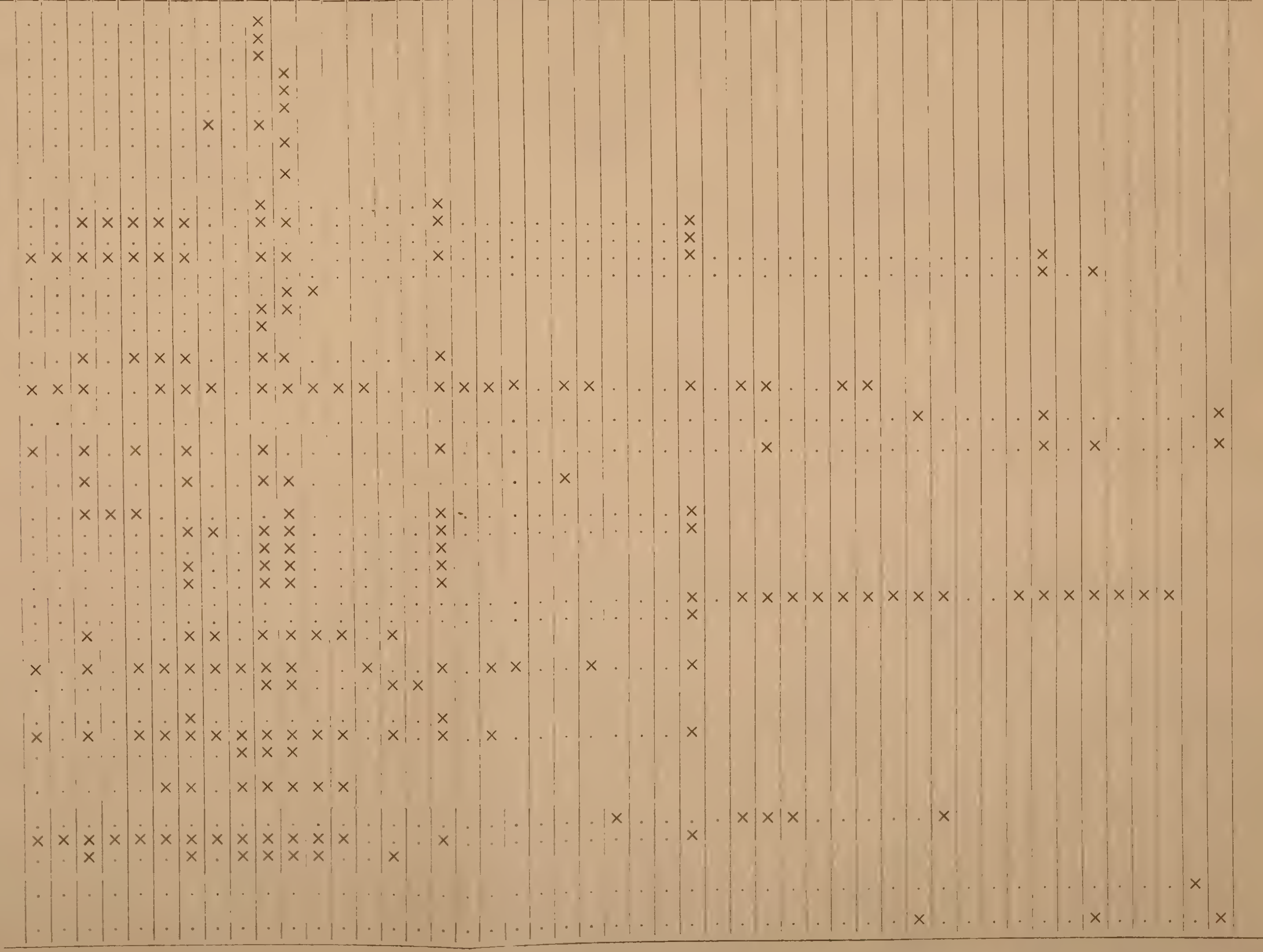



Pseudelaps muelleri (Schlegel)

Apisthocalamus loennbergii Boulenger Apisthocalamus loriae Boulenger Apisthocalamus prattii Boulenge

\section{Pseudapisthocalamus nymani Lönnberg}

Toxicocalamus stanleyanus Boulenger Toxicocalamus longissimus Boulenger

\section{Diemenis olivacea (Gray)}

Diemenia psammophis (Schlegel)

Pseudechis papuanus Ptrs. \& Doris Pseudechis scutellatus Peters Pseudechis australis Gray

Denisonia melanura (Boulenger)

Denisonia par (Boulenger)

Denisonia woodfordii (Boulenger)

Micropechis ikaheka (Lesson) Micropechis elapoides (Boulenger)

Acanthophis antarcticus (Shaw)

Bungarus fasciatus (Schn.) Bungarus candidus (Linne) Bungarus flaviceps Reinhard

Naja naja (Linné)

Naja hannah (Cantor)

Doliophis bivirgatus (Boie) Doliophis integtinalis (Laurenti)

Marine species omitted

Haplopeltura boa (Boie)

Amblycephalus laevis Boie

Amblycephalus malaccanus (Peters)

Amblycephalus carinatus Wagler

Amblycephalus nuchalis Boulenge

Agkistrodon rhodostoma (Boie)

Trimeresurus monticols Günthe Trimeresurus purpureomaculatus (Gray)

Trimeresurus gramineus (Shaw)

Trimeresurus sumatranus (Raffles)

Trimeresurus puniceus (Boie)

Trimeresurus borneensis (Peter )

Trimeresurus wagleri (Schlegel)

(n)

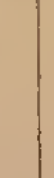

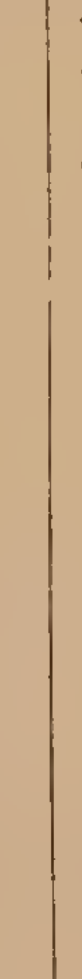<smiles>[Y][C@@H]1[CH]CC1</smiles>

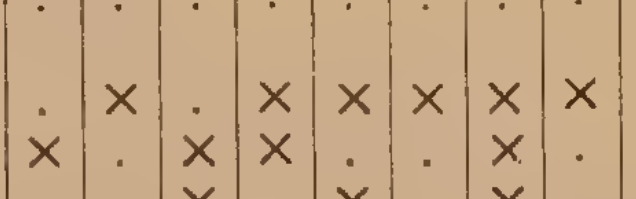

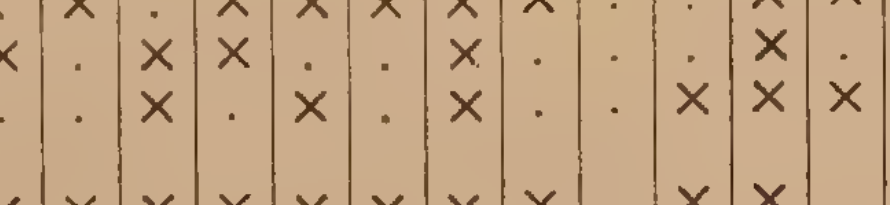

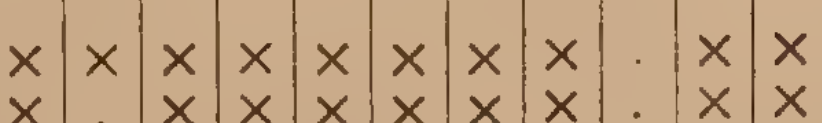

$\begin{array}{lllll} & x & x & x & x\end{array}$

$\begin{aligned} & x \\ & x\end{aligned} x \times x \times$

$\begin{array}{lll}x & x & \\ x & x & \dot{x}\end{array}$

.. . . . $\times x \times x \cdot x$

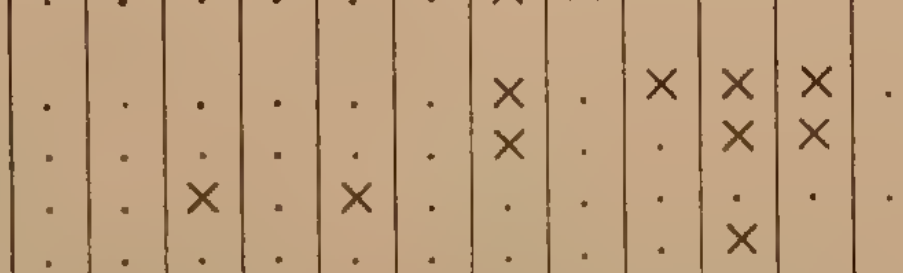

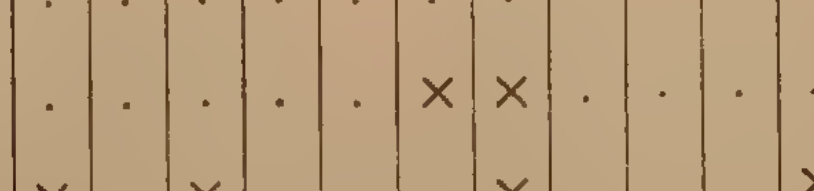

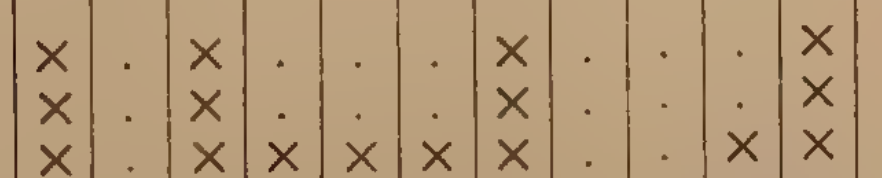

$\mid \begin{array}{ll}x & x \\ x & x \\ x & x \\ x & x\end{array}$

$\left|\begin{array}{ll}x & x \\ x & x \\ x & x\end{array}\right| x$

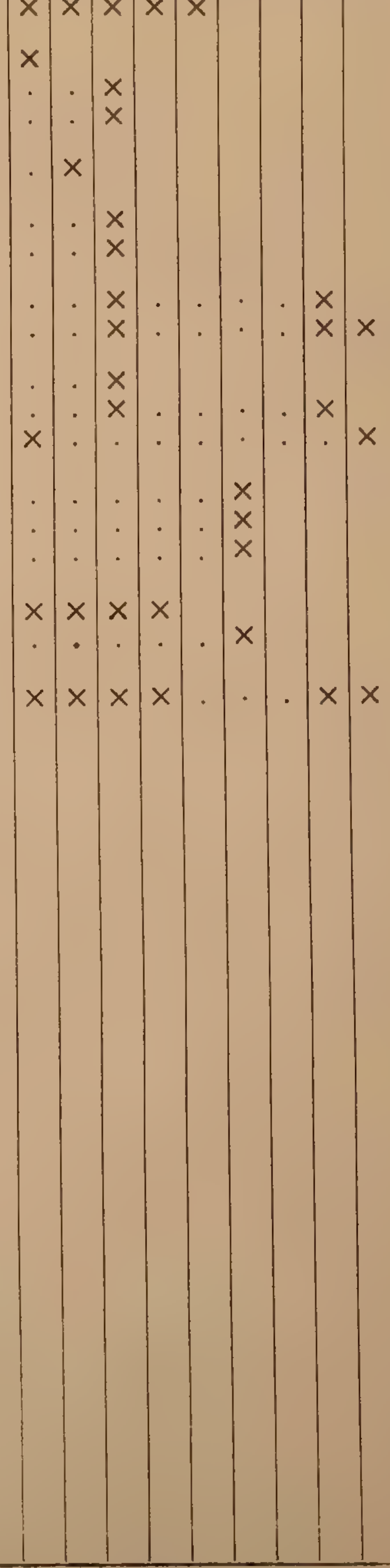



Tegtodinata

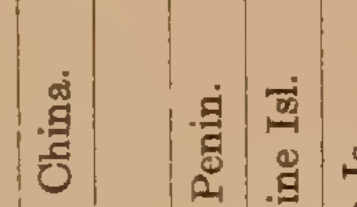

Testudinata

Devisia mythodes Douglas Ogilby

Kachuga trivittata (Dumeril \& Bibron)

Orlitia borneensis Gray

Batagur baska Gra

Callagur picta (Gray)

Bellia crassicollis (Gray)

Heosemys spinosa (Gray)

Cyclemys platynota (Gray)

Cyclemys amboinensis (Daudin)

Geoclemys subtrijuga (Schl. \& Müll.)

Geoemyda spengleri (Gmelin)

Testudo emys Schl. \& Müll.

Testudo forstenii Schl. \& Müll.

Chelodina novae-guineae Boulenger Chelodina siebenrocki Werner Chelodina oblonga Gray

Emydura macquarii (Gray)

Emydura albertisii Boulenge

Emydura kreffitii (Gray)

Carettochelys insclupta Ramsay

Amyda subplana (Geoffr.)

Amyda hurum (Gray)

Amyda cartilaginea (Boddaert)

Amyda phayrii Theobald

Pelochelys cantoris Gray

Crocodilia.

$+$

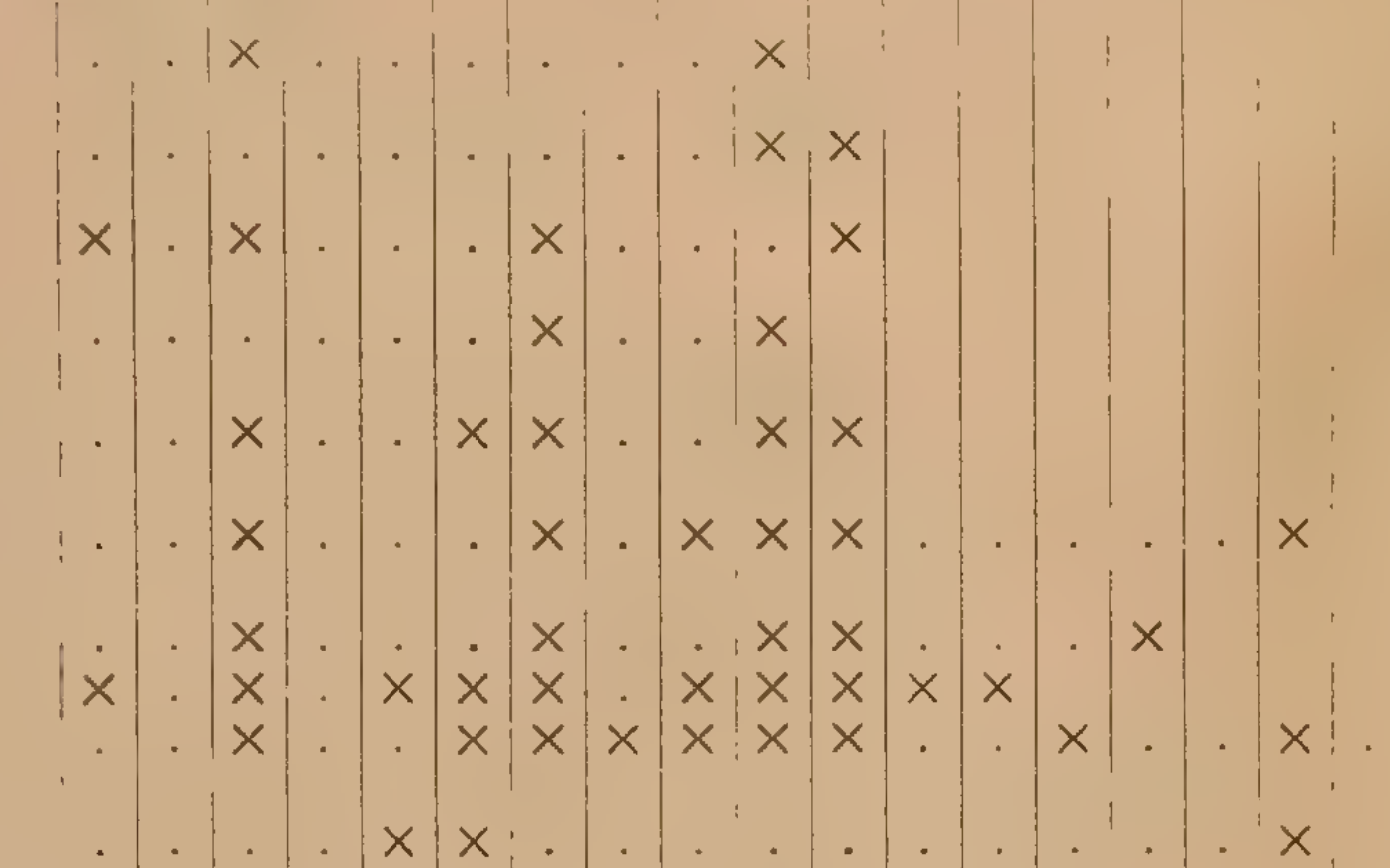

Tomistoma schlegeli (S. Müll.)

Crocodilus porosus Schneider

Crocodilus siamensis Schneider

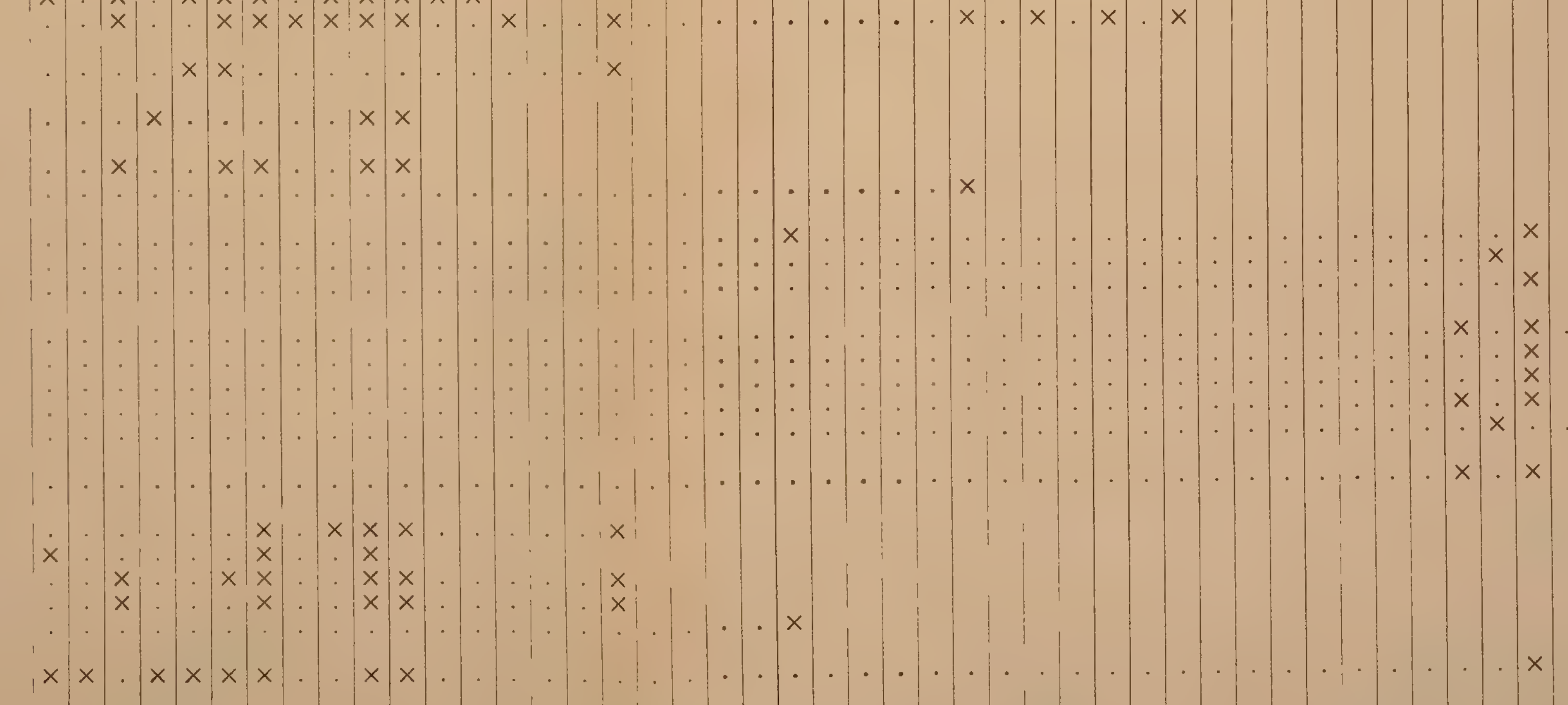

Cr._. 



\section{PLATE 1.}

Fig. 1.-Dasia smaragdinum smaragdinum (Lesson). Sorong, New Guinea.

Page 92.

Fig. 2.-Dasia smaragdinum moluccarum Barbour. Wahaai Ceram Island. Type.

Page 92.

(Figs. 1-2 slightly enlarged). 


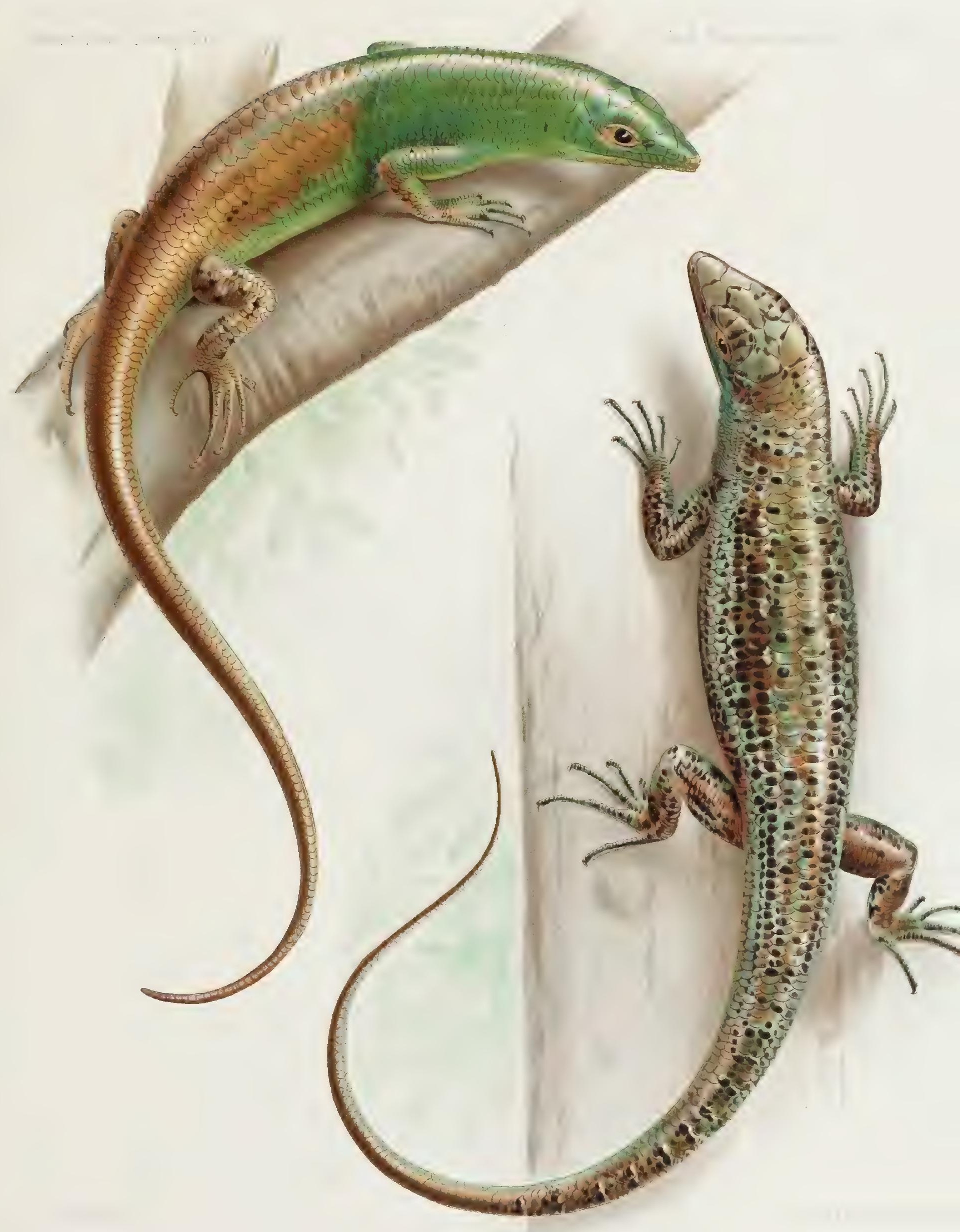




PLATE 2.

Fig. 3.- Leiolepisma pullum Barbour. Humboldt's bay, New Guinea. Type.

Page 93.

(Fig. 3 twice natural size).

Fig. 4.-Dasia smaragdinum viridipunctum (Lesson). Caroline Islands.

Page 92.

(Fig. 4 slightly enlarged). 


$$
\vec{c}
$$






\section{PLATE 3.}

Fig. 5.-Cryptoblepharus boutonii cursor Barbour. Buleleng, Bali Island. Type.

Page 96.

Fig. 6.- Cryptoblepharus boutonii subsp., from Madagascar.

Page 96.

Fig. 7.-Cryptoblepharus boutonii peronii (Cocteau). Saonek, Waigiu Island.

Page 96.

Fig. 8.- Cryptoblepharus boutonii balinensis Barbour. Ampenan, Lombok Island. Type. Page 96.

(Fig. 5-8 twice natural size). 


$$
\begin{aligned}
& 5 \\
& E
\end{aligned}
$$




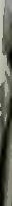



PLATE 4

Fig. 9.- Photo. head of Hydrosaurus pustulosus (Esch.). Phillipine Islands.

Fig. 10.-Same of Hydrosaurus weberi Barbour. Weeda Halmahera. Type.

Page 88.

Fig. 11.-Same of Hydrosaurus amboinensis (Schlosser). Piru, Ceram.

Page 88.

Page 87.

(Fig. 9-11 slightly reduced). 

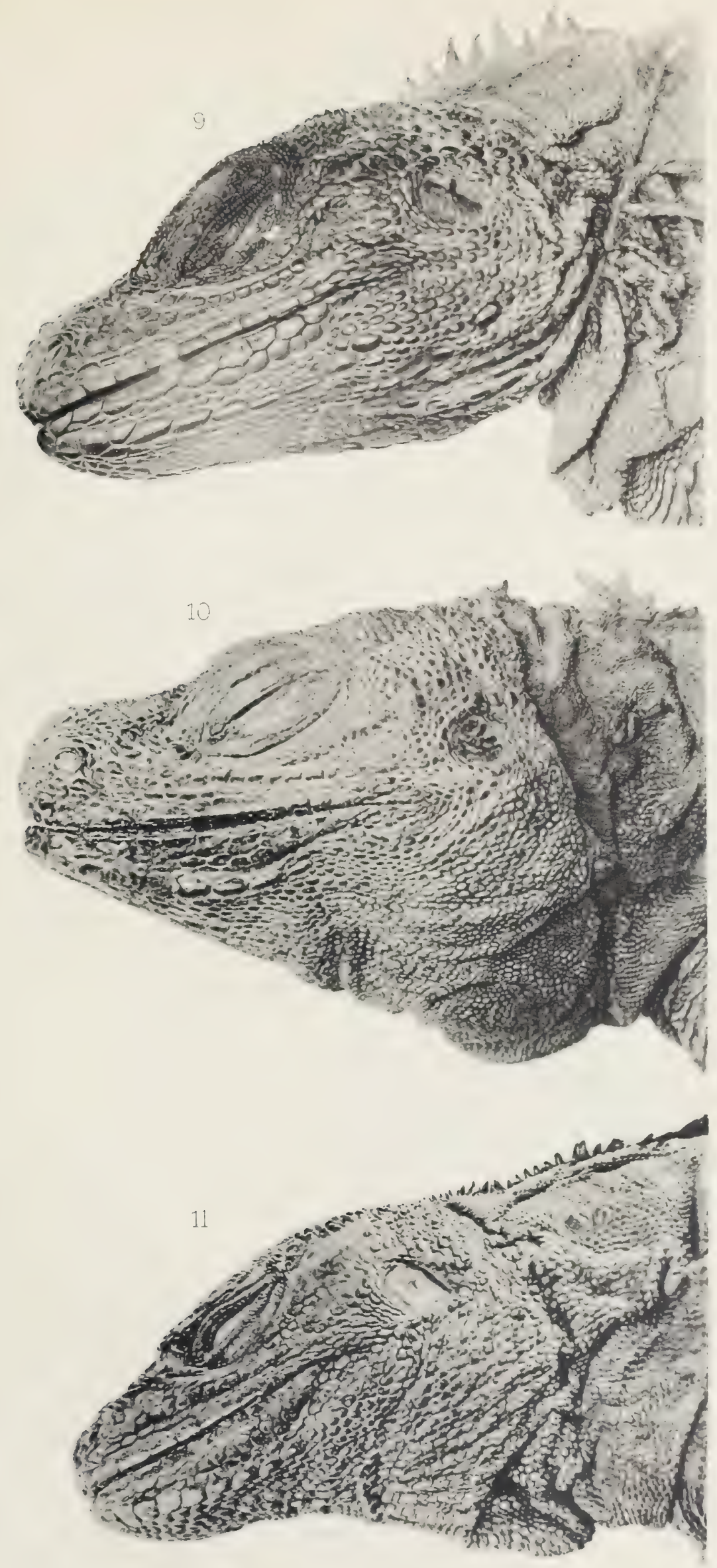


PLATE :

Fig. 12.- Rana moluccana Boettger. Gane, Halmahera.

Page 65.

Fig. 13. - Hyla kampeni Barbour. Wahatai, Ceram. Type.

Page 76.

Fig. 14.- Cornufer corrugatus rubristriatus Barbour. Roon Island. Geelvink Bay, New Guinea. Type.

Page 70 .

Fig. 15. - Rana papua Lesson. Manokwari, New Guinea. Page 65

Fig. 16.-Doliophis intestinalis (Laurenti). Buitenzorg, Java.

Page 137.

(Fig. 12-16 natural size). 

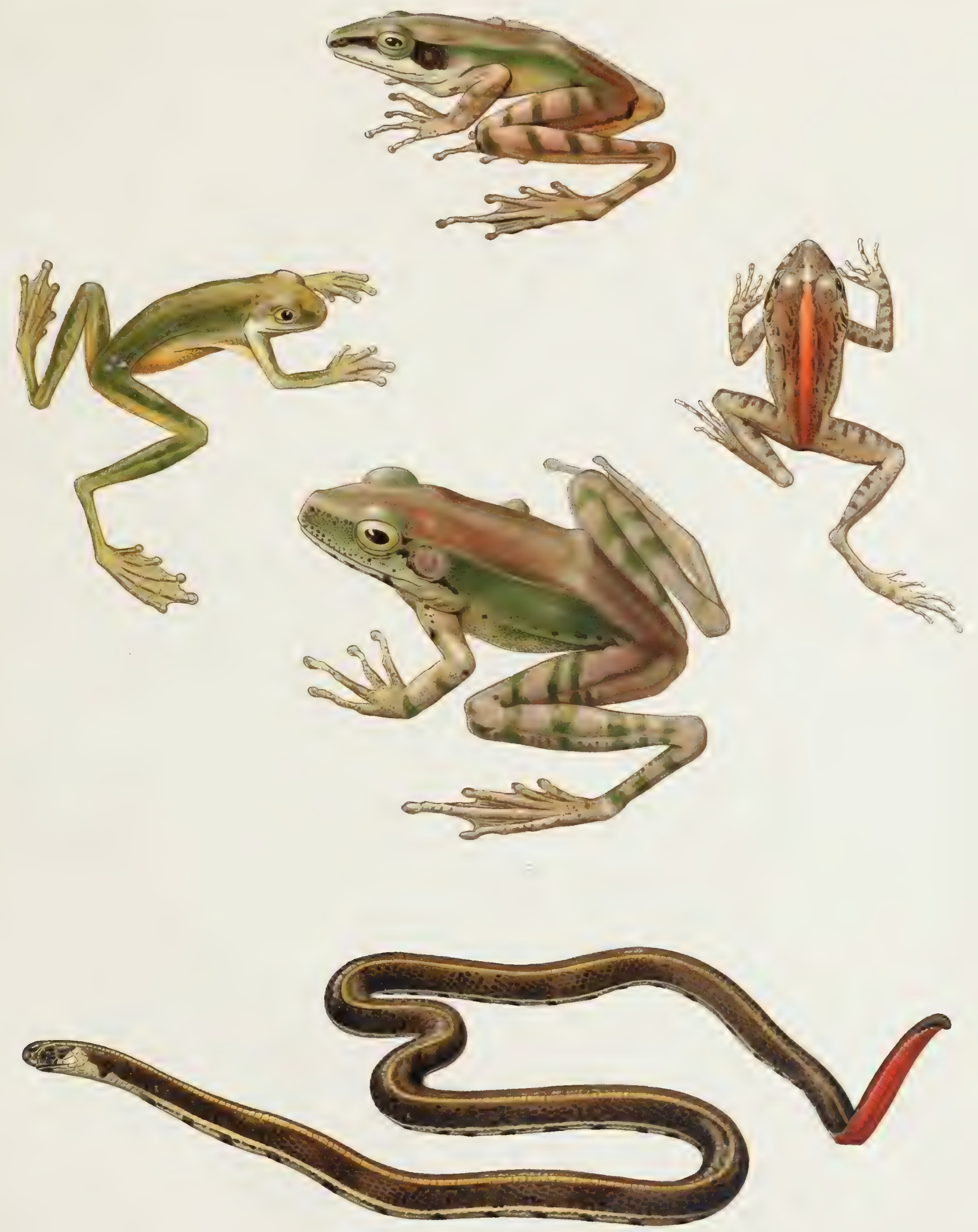


PLATE 6.

Fig. 17. - Doliophis intestinalis (Laurenti). Buitenzorg, Java, dissected to show development of poison gland.

Page 137.

Fig. 18-19. Two views of head of type of Liopeltis libertatis Barbour. Buitenzorg, Java. Page 119.

Fig. 20.- Bufo obscurus (Barbour). Sarawah, Borneo. Type. Page 75.

Fig. 21. - Bufo biporcatus Tschudi. Makassar, Celebes. Page 74.

Fig. 22.- Bufo cavator Barbour. Ampenan, Lombok. Type. Page 74

(Fig. 18-19 twice natural size. Fig. 20-22 natural size). 


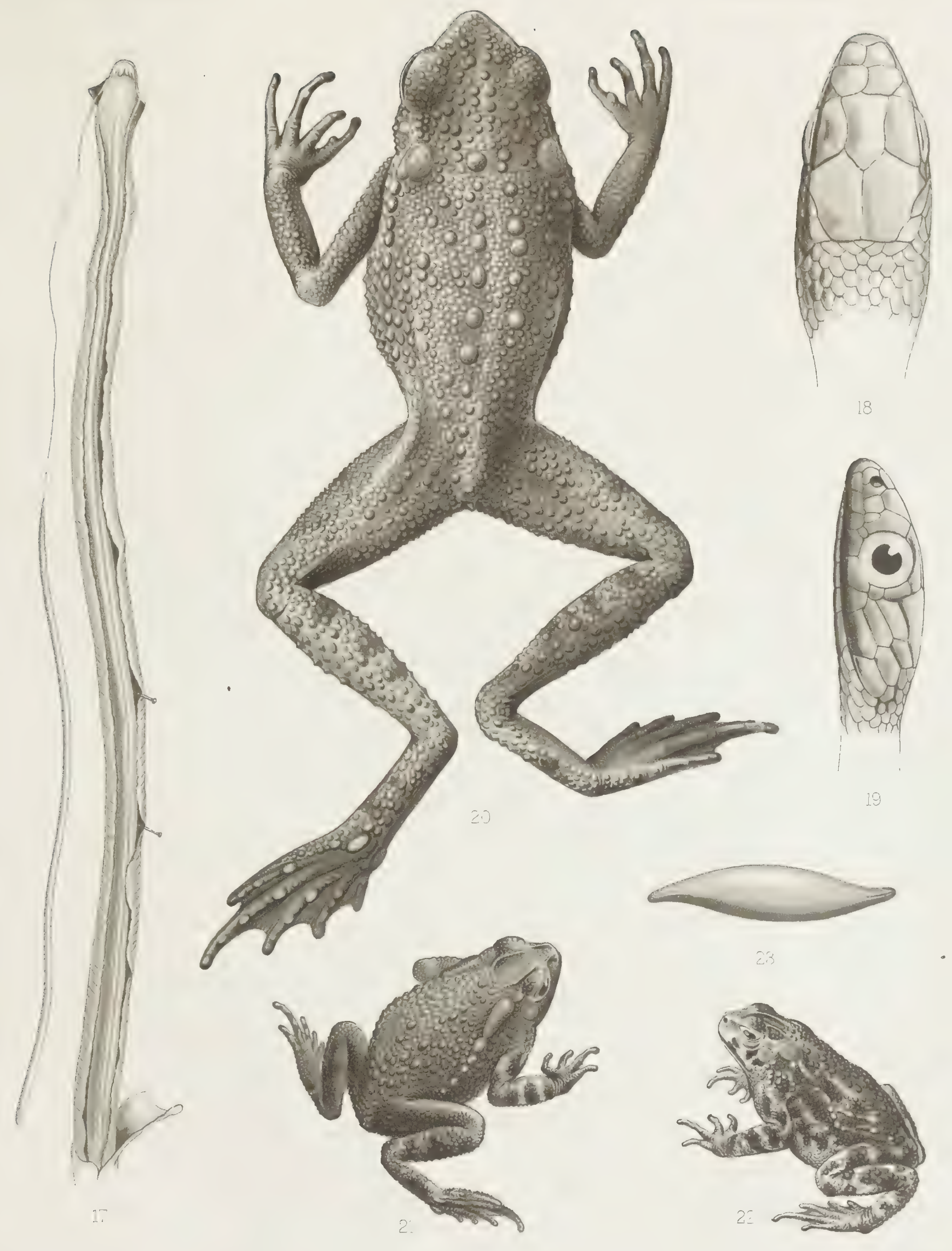




PLATE 7.

Fig. 23. - Egg of Calotes jubatus (Dumeril \& Bibron). Buitenzorg, Java. Page 86.

Fig. 24.-Ptychozoon kuhli Stejneger. Buitenzorg, Java.

Page 82.

Fig. 25. - Hyla (Hylella) ouwensii Barbour. Jobi Island, New Guinea. Type.

Page 77.

Fig. 26. - Microhyla annectans Boulenger, from Tjibodas, Java.

Page 71.

Fig. 27.- Microhyla achatina (Boie). Tjibodas, Java.

Page 71.

Fig. 28. - Microhyla hainanensis Barbour; Proc. N. E. zoöl. club, 1909, 4, p. 57. Mt. Wachi, Hainan. Type.

Fig. 29.- Kaloula pulchra Gray. Makassar, Celebes.

Page 71.

Fig. 30-Megalophrys montana Wagler. Mt. Papaudaiang, Garut, Java.

Page 77.

(Fig. 23-25, 29, 30 natural size. Fig. 26-28 twice natural size). 

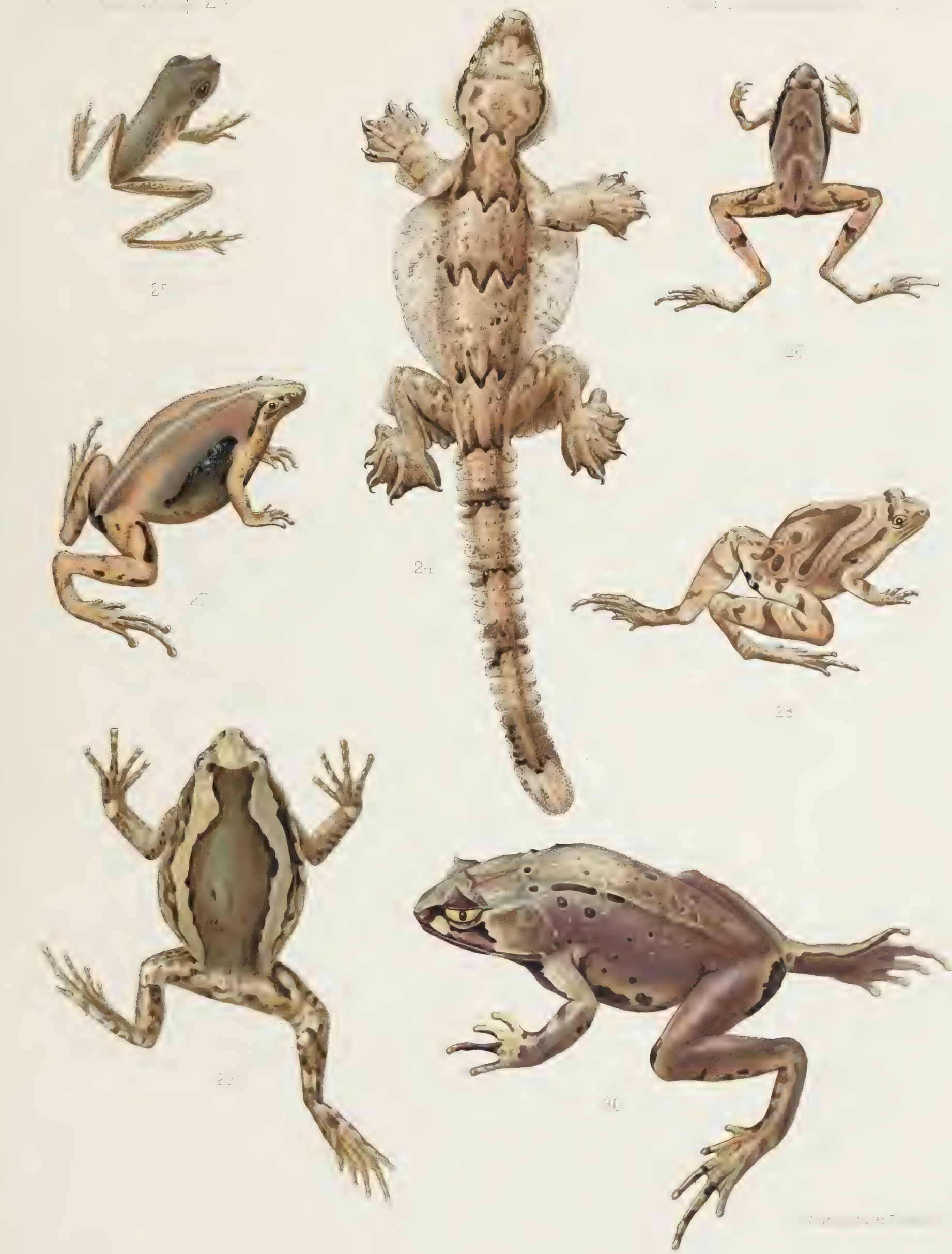




\section{PLATE 8.}

Fig. 31.- Polypedates javanus (Boettger). Tjibodas, Java.

Page 68.

Fig. 32.- Nyctixalus margaritifer Boulenger. Tjibodas, Java.

Page 70.

Fig. 33. - Bufo borbonicus (Boie). Tjibodas, Java

Page 74.

Fig. 34.-Bufo cruentatus Tschudi. Tjibodas, Java.

Page 75.

Fig. 35.-Bufo biporcatus Tschudi. Buitenzorg, Java.

Page 74.

(Figs. 31, 33-35 natural size. Fig. 32 twice natural size) 

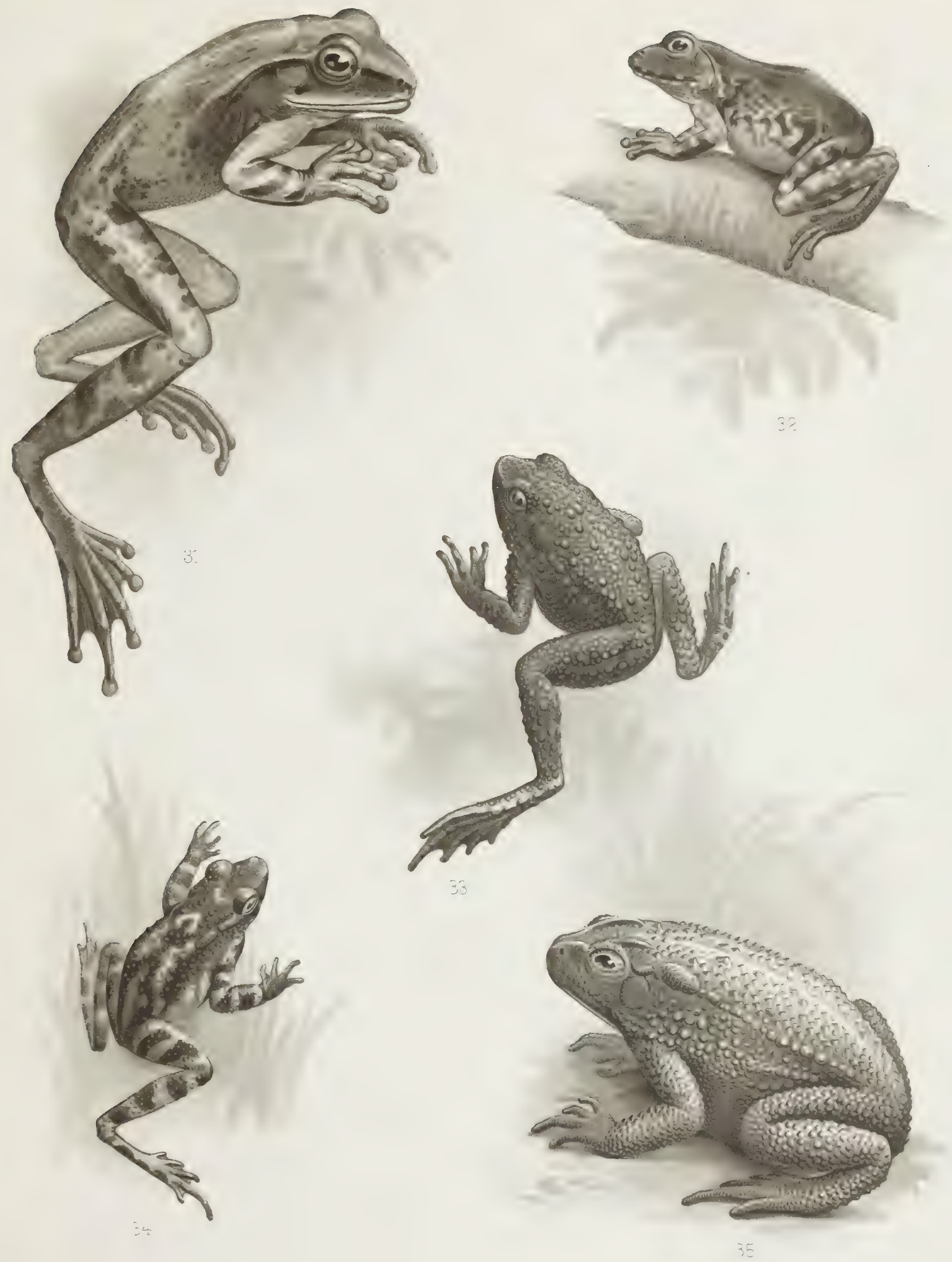




\section{Barbour, Thomas}

AUTHOR

A Contribution to the ZoögeoTITLE graphy of the East Indian Islands 
